\title{
THE CELTIC CEMETERY AT MÉNFŐCSANAK. THE EXCAVATION BEFORE THE CONSTRUCTION OF ROAD NO. 83 IN 1993-94
}

\author{
ANDREA VADAY* - KÁROLY TANKÓ** \\ * University of Pécs, Department of Archaeology \\ 2 Rókus u, H-7624 Pécs, Hungary \\ vaday54@gmail.com
** MTA-ELTE Research Group for Interdisciplinary Archaeology, Eötvös Loránd University
4/B Múzeum krt, H-1088 Budapest, Hungary
tanko.karoly@btk.elte.hu

\begin{abstract}
One of the important cemetery and settlement of the Celts lies in a plateau on the southern side of the the Öreg Rába river, in the vicinity of Győr-Ménföcsanak. The first burials were found in 1967 during a short rescue excavation, however it made Ménföcsanak a key La Tène site in the Carpathian Basin. Excavations investigated on a larger scale in the area of previously known cemetery in 1993-94. The burial rite of the necropolis was mainly inhumation and only two graves were cremated and two biritual graves. Celtic warriors with swords and richly furnished female with fibulae, coral, amber, and glass beads jewelry were also buried in this part of cemetery. Few graves were limited by rectangular enclosing trenches. According to find analyzing this part of the cemetery dates to the LT B period, and that is why Ménföcsanak became an important archaeological site in terms of burials in the history of the Celtic "migrations" in the fourth century BC.
\end{abstract}

Keywords: Late Iron Age, La Tène culture, Celtic cemetery, NW Hungary

\section{INTRODUCTION}

In 1993-94, the excavations of the track of national Road 83 bypassing Ménföcsanak, which has been constructed since then, unearthed further graves of the biritual Celtic cemetery at Ménföcsanak-"Savanyitó" rescued and published earlier by András Uzsoki. ${ }^{1}$ Another rescue excavation was conducted on the surface adjoining Road no. 83 in $1995-96 .{ }^{2}$ Here the Celtic graves unearthed at the rescue excavations of the Road no. $83^{3}$ will be published. ${ }^{4}$

In the course of the investigation of the continuous track, rescue excavations were conducted in three subsequent territories. One was the so-called Szeles part joining the exit of highway M1 from the west ${ }^{5}$ the second one was the so-called third surface bordering the previous one from the north-west and the third one was the Savanyitó surface beyond the former one. ${ }^{6}$ The Zsigmond király Road partly covered by concrete, flanked by gutters, runs between the Savanyíto and the third surface. It leads from the settlement of Ménföcsanak toward the dead

${ }^{1}$ András Uzsoki published not the complete excavation and only some of the graves found during the excavations. UzsoKI 1968, UzSOKI 1969a, UzsoKI 1969b, UzsоKi 1970a, UzsoKI 1970b, UZSOKI 1970c, UZSOKI 1987.

${ }^{2}$ The excavations were conducted by Ildikó Egry, Eszter T. Szőnyi, Péter Tomka and Andrea Vaday. The rescue excavations were carried out on separate surfaces. The publication of the Celtic graves of the former cemetery found this time was passed to I. Egry according to a consensus with E. T. Szőnyi and P. Tomka.

${ }^{3}$ VADAY 2003, 201-202, VADAY 2004, 201-202, VADAY 2006a, 597-610, VADAY 2006b, 279-294.
${ }^{4}$ The processing was made with the financial assistance of the competition of OTKA T 32253 and OTKA T 047072. Map of the cemetery made by Andrea Nagy, the plates made by Margit Szabados and A. Vaday, the figures made by A. Nagy and A. Vaday. The photos made by Tibor Kádas and A. Vaday.

${ }^{5}$ This surface is the closest to Gyorr.

${ }^{6}$ It was a lucky coincidence that the three excavation surfaces yielded finds and features from different archaeological periods as well. The marking of the territories by different names was also necessitated by the parallelly conducted excavations in the territories. 
channel of the Marcal, then turns westwards toward Gyimrót. ${ }^{7}$ At the time of A. Uzsoki's rescue excavations, it was only a dirt road. The Kertészeti Vállalat (Horticultural Enterprise) used the lands south of the stretch that runs in a west-east direction, nearly parallelly to the Marcal. The Zsigmond király Road, the fence of the one-time Savanyító buildings and its older buildings together with the high-tension line that crosses the road, which ran in a N-NW direction of the projected Road no. 83, helped the connection of the old rescue excavations and the surfaces of the excavations conducted in 1993-94. The buildings of the former acidifying plant (savanyitó) or raspberry acidifying plant were raised S-SW of the track. A drainage ditch ran outside the southern side of the fence of the works, which has mostly been overgrown by now. ${ }^{8}$ A. Uzsoki rescued Celtic graves and collected data of destroyed graves during the digging of the drainage ditch, the constructions carried out in the territory of the works as well as on the lands of the Horticultural Enterprise.

The excavations in 1993-94 were carried out, according to the preliminary plans, in a $30 \mathrm{~m}$ broad stripe, sometimes with smaller corrections. Zsuzsanna B. Kiss helped with the excavation of the Celtic cemetery. Occasionally Elek Benkő, Gabriella T. Németh, and Miklós Takács gave a helping hand. ${ }^{9}$

In 1995, new rescue excavations were started, connected to those of Road no. 83, next to the Szeles surface before the construction of the METRO shopping center. Rescue excavations had already been conducted beside the so-called third surface as well in 1996, which resulted in further Celtic graves. There were no Celtic graves in the cuttings opened in the Szeles part. ${ }^{10}$

\section{GEOGRAPHICAL FEATURES OF THE SURFACE UNEARTHED IN 1993-94}

A hill topped by a plateau follows the bank of the Öreg Rába. Several old ravines running approximately from the north to the south segment the plateau. They are partly filled in with loam and alluvial deposits, while the hill itself is covered with sand or loess sand. The surface layer is thin greyish humus enriched partly with sand, partly with loess both on the plateaus and in the ravines.

A hill covered with sand on the crest crosses the track in an approximately $\mathrm{N}-\mathrm{S}$ direction close to the Zsigmond király Road at the end of the Savanyító surface. Most of the Celtic graves were found on this hilltop and only a few were scattered in the western and eastern slopes. The last graves of the cemetery were situated 30-32 m west of the Zsigmond király Road. Neither Celtic graves nor Celtic settlement features were spotted in this 30-32 $\mathrm{m}$ broad stripe and the so-called third excavation surface east of it. This stripe had been the basin of an intermittent stream partly filled up by the Celtic period. There was a gradually darkening, blackening, moist clayey filling mixed with humus at the slope in the south-eastern part of the cutting. The soil changed towards the north-west, $80 \mathrm{~m}$ from the concrete road, at the north-western slope: the yellow sand was gradually replaced by a grey than a black layer between $80-92 \mathrm{~m}$. Here a yellowish-grey thick clay was found, which filled in the deeper ravines. (Fig. 1.2)

Besides the Celtic cemetery, some scattered Iron Age, Roman, and Avar period settlement fragments were found in this excavation area. The features of the Roman and Avar settlements were distributed mainly above the south-eastern part of the Celtic cemetery on the slope that was yet very moist at the turn of the $4^{\text {th }} / 3^{\text {rd }}$ centuries BC but dried up by the Roman period and thus became suitable for settlement. In the north-western part, at the same time, the last features of a settlement from the Árpádian Era were detected partly overlapping the last graves of the Celtic cemetery. Due to the various soil qualities, the possibilities for observation on the surface were not uniform. The features from the Roman and Migration periods were excellently outlined after the scraping of the black clayey, moist filling in the south-eastern part of the Celtic cemetery. The Celtic graves and grave ditches were also visible although less clearly than the former ones (features 298, 738, 307, 301, 351, and partly 302). The situation was different in the north-western part of the hilltop. The features from the Roman, Migration, and Árpádian periods showed sharp outlines against the greyish white clayey surface. The westernmost Celtic objects outlined on the

${ }^{7}$ Road no. 83 joining into the stretch of highway M1 bypassing Györ, where rescue excavations were conducted in 1993-94 and which was opened in 1994, intersected the Zsigmond király Road. The Old Rába could no longer be reached from here. At present, Zsigmond király Road ends at the buildings of the Savanyító.

\footnotetext{
${ }^{8}$ This is the same ditch that separated the Szeles and the third excavation surfaces to the north-east.

${ }^{9}$ Here we would like to thank them for their contribution.

${ }^{10}$ The rescue excavations were conducted by I. Egry, E. T. Szőnyi, P. Tomka (Museum of Xantus János, at Győr) and A. Vaday (Archaeological Institute of the Hungarian Academy of Sciences).
} 
scraped surface were the following ones from north to south: $755,756,368,377,450$, and 465 . Grave ditch no. 745 appeared $25 \mathrm{~cm}$ even deeper than the above features. The outlines of graves nos 754 and 752 appeared under the levels of the Migration and Árpádian periods. Graves nos 754 and 737, at the same time, could be spotted only $45-47 \mathrm{~cm}$ deeper. At present the surface is flat. The original surface formation was significantly different.

Both the south-eastern and the south-western slopes were partly filled up before the Celtic period but both depressions contained intermittent watercourses at the time of the Celtic occupation. So it is plausible that the graves stretched until the desiccated bank of the watercourse. It means that the expansion of the cemetery towards east and west was hampered in this part of the track by the watercourse, the groundwater, and also by the weather, and, at the same time, they functioned as boundaries as well. The deeper graves were covered in the north-western, deeper clayey part by the fluviatile clay deposit of a greater flood after the Celtic period. The slope was significantly steeper here in the Celtic period than in the south-eastern part and the graves at the edge of the slope were covered with the deposits of a flood sometime between LT B1 and the $8^{\text {th }}$ century AD. The features of the Avar period were sunk into this, by then desiccated filling.

Both the sandy and the grey clayey soils made the spotting of the graves difficult. The so-called Ménföcsanak-Szeles surface was first uncovered, where the same changes of soils could be observed as later along the track of the Savanyitó. The outlines of the shafts of the Middle Bronze Age graves were only rarely visible on the scraped surface of the sandy hilltop in the Szeles part. The surfaces between the graves seemed archaeologically intact. Nevertheless, the surface of the sandy soil open to the strong winds changed where there was no high vegetation in the area of the cemetery to bind it. New topsoil was built by the wind in the spring and the late autumn or at the beginning of the winter. This resulted that a seemingly intact, unbroken layer was deposited by the wind over the earlier graves. For lack of thick vegetation, the humus layer under the ploughed layer could be differentiated by its organic material content and not by its colour or texture, which made the recognition of the grave outlines difficult. A 30-40 cm thick humus was removed by the scraper in this area, and the black humus stripes of the modern deep ploughing often appeared on the scraped surface. Some of the graves of the Encrusted Pottery Culture lay on the border of the ploughed soil, so sometimes the plough dragged the graves that lay higher. The same was the situation in the depressions between the hilltops where the floods of the Rába covered the archaeological floor levels with a clayey inundation loam. On both surfaces, test cuttings were deepened to a greater depth even where there appeared no trace of human activity on the surface, and we found further archaeological features that had been covered with inundation soil or drifted sand. After the experiences on the Szeles surface, similar control cuttings were used in the Savanyito territory both in the looser sand and in the inundation area where no archaeological features had been found. In result, we found out that the ravine in the south-western part of the Celtic cemetery was filled up mainly before the LT B1 period, while another flood deposit covered the inundation layer from before the LT B1 at the deeper slope on the north-western, steeper side of the hills after the LT B1. In the Celtic period, however, both ravines must have been dryer than at present, as the graves were often moist in the two above-mentioned lateral belts during the rescue excavations and some of them even stood underwater. Groundwater seeped strongly in the lowermost 10-20 cm of graves nos 752, 754, and 737 in the north-western part, and it was evident from the bones and the finds as well that they had frequently stood in intermittently rising water. It is improbable that the graves were deepened to the groundwater level or even deeper in the Celtic period, so this observation offered another opportunity for comparison. The traces of a filling in a dryer and windy period could be observed on the crest of the hill. Sand mixed with drifted loess covered the earlier unearthed graves nos 376/A and 376/B, while the nearby grave no. 377 must have been deepened already into the accumulated sand since this appeared first at scraping.

The extension of the cemetery could be determined in the track of the road from excavation experiences as well as from the soil structure, which was supported by later excavations along the track towards south-east and also north-west. 


\section{DESCRIPTION OF THE CEMETERY}

\section{a. Description of the graves}

The ritual elements and the order of use are rather complex. The graves were not numbered continuously, the numbers of the graves and the grave ditches are the numbers given to the features at the excavations. The graves were not given new numbers in the publication. Characters A-B-C are added to the numbers if the burials were in superposition. The sub-numbers 1 or 2 after the grave numbers indicate the contemporary burials in the same grave shaft.

In the inventory, the number of the grave sheet was indicated beside the ordinary number of the described find. This number is identical to the find numbers on the grave sheets of the excavation documentation.

\section{Grave no. 298}

Shape and measurements of the cremation grave: The outline of the grave shaft appeared as an irregular round discolouration in the black, greasy, moist clayey soil in the level of the subhumus. Its filling could be distinguished from the environment being darker black, sooty with several large charcoal lumps.

The diameter of the elongated circular shaft was $120 \times 120 \mathrm{~cm}$. Relative depth: $12 \mathrm{~cm} .{ }^{11}$

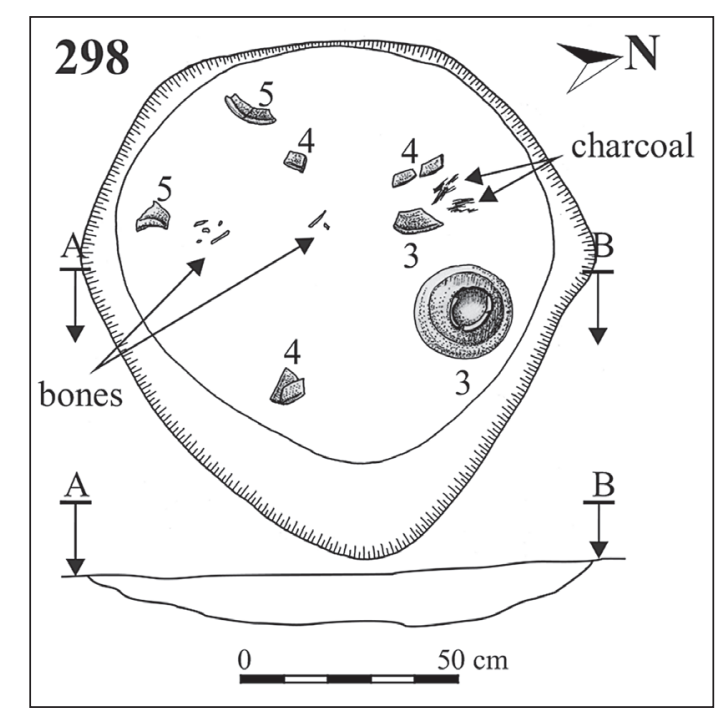

Description: A Roman sherd with striped red painting was found during scraping. Besides, the fragments of a brick-coloured wheel-thrown bowl with everted rim were found in the centre and in the northern part of the discolouration, which was separated by the plough. The fragments are weathered. The small fragments of the same bowl and other, indeterminable sherds were found in the western part of the pit, together with large charcoal lumps 2-6 cm above the bottom of the shaft. The cross-section showed that the whole shaft was full of smaller and larger charcoal lumps. The charred bones lay in the filling also in the central part of the grave. The most intact find was an urn. The filling of the urn was different from that of the shaft. It contained a little soot and was of a lighter colour. The quantity of charcoal was also smaller than in the shaft. The human ashes were in the urn, and two burnt iron fibulae lay on the bottom of the urn under the ashes. Traces of secondary burning could be detected on the urn itself.

There is no definition of sex and age determination of the cremation grave.

\section{Finds:}

1. A large iron fibula. Only the spring gear with a large spiral, the bow, and a fragment of the pin survived. The bow is circular in cross-section. Probably burnt. (Fig. 2.2)

${ }^{11}$ The relative depth was measured from the scraped surface where the features appeared. 
2. A smaller iron fibula. It has broad spiral wings with the chord external, the bulging bow is round in cross-section. The end of the foot, which is narrower than the bow, was returned on the bow. (Fig. 2.1).

Grave furniture:

1. A greyish black, wheel-thrown urn. It was baked in a reducing environment and it was secondarily burnt as well. The bottom is omphalos-shaped, and there is a circular groove $1 \mathrm{~cm}$ above the omphalos. M.d. $=11 \mathrm{~cm}$, B.d. $=3 \mathrm{~cm}, \mathrm{H} .=14.6 \mathrm{~cm}$. (Fig. 2.4 and Fig 31.3)

2. A wheel-thrown, greyish yellow bowl with everted rim. The clay was tempered with sand. There is a rib in the arch of the neck. M.d. $=23 \mathrm{~cm}$. (Fig. 2.5)

3. A fragmentary urn. The rim is burnt to a light grey colour, the shoulder is greyish brown, the bottom is reddish. Only fragments have been preserved. The clay was tempered with sand. M.d. =13 cm. B.d. =app. $12 \mathrm{~cm}$. (Fig. 2.3)

\section{Grave no. 301}

Grave ditch: feature no. 351

The surface slopes in the north-eastern part of the area, where the yellow sandy soil is gradually replaced by a black, moist deposit that fills in the natural depression. The grave ditch (feature no. 351) was vaguely outlined already in this greyish black transitional zone. The grave ditch is of an irregular quadrangular shape with rounded
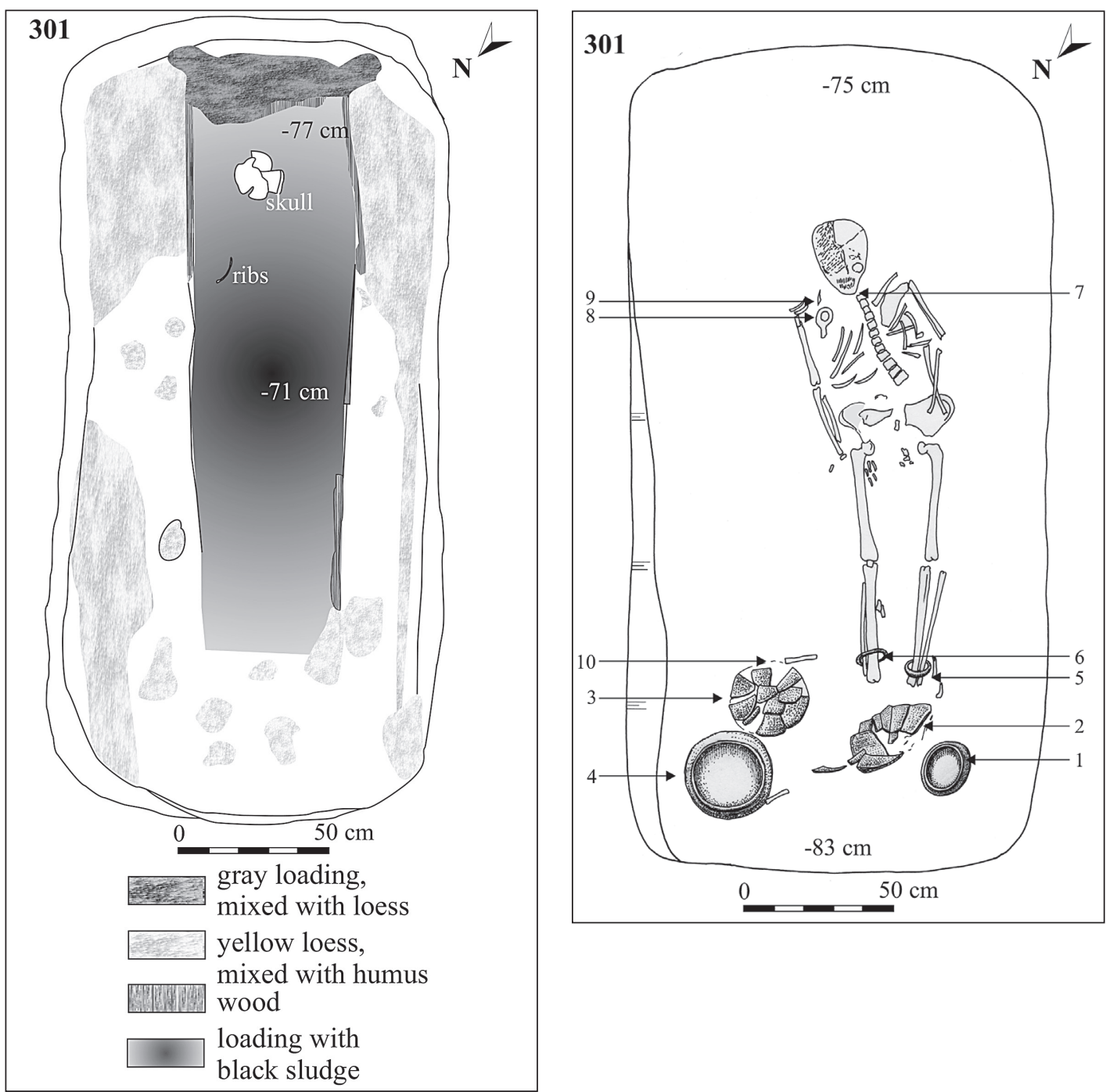
corners. The sections of the ditch are not straight, their direction is sometimes irregular. Measurements of the ditch: length in the eastern part: $7.65 \mathrm{~m}$, width $25 \mathrm{~cm}$, inner length: $7.15 \mathrm{~m}$; outer length in the north: $7.25 \mathrm{~m}$, inner length: $6.70 \mathrm{~m}$, width: $30 \mathrm{~cm}$, length in the west: $7.35 \mathrm{~m}$ outside and $6.60 \mathrm{~m}$ inside, width: $30 \mathrm{~cm}$, length in the south $7.40 \mathrm{~m}$ outside and $7.30 \mathrm{~m}$ inside, width: $30 \mathrm{~cm}$. The filling of the ditch is uniformly greyish yellow, somewhat mixed with sand. It could be observed only vaguely in narrow lines on three sides, while the south-western part could not be spotted at the first scraping. Later, $5 \mathrm{~cm}$ deeper, this section also appeared, although dimly. The ditch was difficult to excavate here, it could barely be distinguished from the surrounding, inundated humus. The filling of the ditch was dark brown here in the blackish humus. It had a semicircular cross-section, its depth varied between 8 and $10 \mathrm{~cm}$ from the surface where it had appeared. The direction of the axis of the grave ditch was the same as that of the grave it framed. Twenty-five $\mathrm{cm}$ from the southern corner of the south-eastern section of the ditch, a circular discolouration of a diameter of $60 \mathrm{~cm}$ appeared, which was younger than the grave ditch since it intersected the latter. It contained no find material, the filling was uniform, greyish, mixed. Another circular spot appeared at the northern third of the western section of the ditch $150 \mathrm{~cm}$ from the corner. Its diameter was $90 \mathrm{~cm}$. The grave ditch intersected this pit. The filling of the ditch was uniform greyish humus, while the intersected pit was naturally filled in with darker greyish black humus during a longer time. It did not contain find material either.

Shape and measurements of the grave: The grave appeared on the surface as a sub-quadrangular discolouration with rounded corners. The soil was darker, black, and moist in the eastern part. The grave shaft somewhat narrowed downwards. Its length was $270 \mathrm{~cm}$ (along the medial axis), its width was $130 \mathrm{~cm}$ at the southern end and $120 \mathrm{~cm}$ at the northern one. Its depth was $83 \mathrm{~cm}$ in the northern side and $79 \mathrm{~cm}$ at the head in the southern side. The bottom slightly rose towards the head.

Orientation: $\mathrm{N}+237^{\circ}$

Description: The spot of the grave appeared as a dark discolouration. The shaft had a dark brown, moist filling in the upper $23 \mathrm{~cm}$, then a sandy yellow filling, strongly mixed with loess followed. Here, the walls of the shaft were deepened into a bright dark yellow compact waterlogged soil. Under this level, the shaft was dug into a loose ground of fluviatile sand mixed with clay. Tiny charcoal pieces were densely scattered in the filling of the grave.

The first find, a cracked vessel, was found in the shaft in the depth of $60 \mathrm{~cm}$. Another grave appeared as a narrower black discolouration in the depth of app. $70 \mathrm{~cm}$, under the loess. A clayey band, probably plaster, could be observed at the skull in the eastern and southern sides. The skull was strongly fractured. The poorly preserved fragments of iron and bronze objects, better to say their rust and patination, could be observed in the filling of the shaft.

The bottom of the shaft sloped, brownish, scaly, flaky discolourations appeared in the depth of $70 \mathrm{~cm}$ in the northern side and in the depth of $77 \mathrm{~cm}$ in the southern part. The discolourations imply a catafalque. The length of the catafalque was $225 \mathrm{~cm}$, its width $50 \mathrm{~cm}$, the discolouration of the wood was $2-3 \mathrm{~cm}$ thick. The handles of the catafalque standing at a slight angle to one another could be documented in the southern part, they reached $17 \mathrm{~cm}$ over the frame of the catafalque. The traces of a crossbeam could be observed on the northern side (foot region of the grave) parallelly to the end of the catafalque near the middle of the grave. The crossbeam was $42 \mathrm{~cm}$ from the foot-part of the catafalque.

In this depth, traces of surface destruction could be observed along the longitudinal axis between 140 and $190 \mathrm{~cm}$ from the northern end of the grave, approximately in the central part, in a width of $102 \mathrm{~cm}$. At first sight, it seemed to be a later violation. At scraping, however, it turned out that the filling was blackish, moister, and loamier in a band. It seems that a heavier rainfall had washed earth into the deeper parts of the grave at the time of the burial before the rite was finished. The traces of this rain were unearthed.

The $150 \mathrm{~cm}$ long, very poorly preserved skeleton did not lie in the axis of the grave but in the eastern half, with the skull in the south-east. It was laid on the back, in an extended position, the right hand was put under the pelvis, the left hand on the pelvis (the bones of the hand are missing). The bones of the legs were also missing. The vertebral column was bent towards the middle of the grave. The smaller bones crumbled, and the rest of the bones were also very poorly preserved. Juvenile, 17-19 years old, the sex cannot certainly be determined. ${ }^{12}$

\footnotetext{
${ }^{12}$ Determination by Kitti Köhler. Here we should like to thank her for her work.

Acta Archaeologica Academiae Scientiarum Hungaricae 71, 2020
} 


\section{Articles of wear:}

There were several fragmentary iron objects found at the right clavicle, which could not be determined. Some of them were only indicated by their traces (grave sheet nos 8-9).

1. (7) A bronze chain round the neck, it slipped towards the left clavicle. The first three small links of round cross-sections were joined, then the three chains were twisted together. (Fig. 3.2)

2. Fragments of chains from circular, massive links: one was made from larger oval links (diam.: $2.5 \times 1.5 \mathrm{~cm})($ Fig. 3.8), the smaller one was also of oval links (diam.: $1.8 \times 1 \mathrm{~cm}$ ), with textile remains in the iron rust. (Fig. 3.10)

3. A broken iron pin of circular cross-section. (Fig. 3.9)

4. An amorphous laminated (?) iron lump with textile remains. (Fig. 2.9)

5. An iron sheet fragment also with textile remains. (Fig. 2.10)

6. Fragments of iron objects of various measurements, outlining an 8-shape, with earth rusted onto their surfaces. Remains of textiles could be spotted on their surfaces on both sides. The textile imprints on the two sides of the objects suggested cloths of different thread thickness and weaving methods. (Fig. 2.6,7,8)

7. An iron fibula, rusted to a degree that it could hardly be identified, was found at the same place. The knob at the end of the foot of the one-piece fibula rusted to the bow. A fragment of the pin could also be identified. (Fig. 3.6)

8. Another one-piece iron fibula rusted to the above one. The knob at the end of the foot was returned to the bow. It bears an arched ridge ornament. (Fig. 3.7)

9. (6) A bronze anklet on the right leg. It is solid, round in cross-section, plain inside, beaded outside, with grooved transversal lines on the protuberant beads. Both terminals are arched and strongly seal-shaped. Diam. $=7.5 \mathrm{~cm}$. (Fig. 3.5)

10. (5) A bronze anklet on the left leg. It is the pair of the above one. Diam. $=7 \mathrm{~cm}$. (Fig. 3.4)

11. Fragment of a bronze wire found in the filling in the upper part of the grave shaft. It is round in crosssection. It could be a fragment of the chain. (Fig. 3.1)

12. A kidney-shaped iron object from the filling of the grave. It is a thin iron sheet. (Fig. 3.3)

Grave furniture:

1. (3) The fragments of a larger broken urn were found $20 \mathrm{~cm}$ outside the right ankle. The bones of the right foot were scattered among the sherds of the urn (an animal must have displaced them). The clay of the urn was slightly tempered with sand, its colour is black in the centre of the cross-section and brick-colored near the surfaces. A black layer covers both surfaces. It has an everted rim and bears a rib on the neck. It is strongly weathered. M.d. $=16 \mathrm{~cm}$, B.d. = $11.6 \mathrm{~cm}$, H. = ? (Fig. 3.14)

2. (4) The fragments of a larger bowl were found in the corner between the urn and the northern shorter wall of the grave. It is black on both surfaces, brick red in cross-section, the rim is everted and there is a ridge in the arch of the neck. The vessel was broken and only the weathered fragments could be found in the grave. M.d. $=29 \mathrm{~cm}$, B.d. = unmeasurable, H. = unmeasurable. (Fig. 3.13)

3. (2) A vessel broken into pieces was found at the feet. Some small perforations of a diameter of 2-3 mm can be observed in the wall of the vessel, one of the perforations was not completed. The rim is everted and there is a rib in the arch of the neck. M.d. = $14 \mathrm{~cm}$, B.d. = unmeasurable, H. = unmeasurable. (Fig. 3.12)

4. The sherds of a dark, wheel-thrown vessel were found among the fragments of the bowl no. 3 . M.d. $=9 \mathrm{~cm}$, B.d. = unmeasurable, H. = unmeasurable. (Fig. 3.11)

5. (1) There was a smaller vessel beside the above one. The bowl? baked in a reducing environment broke into tiny pieces and it could not be reconstructed even by restorers, it practically weathered away. ${ }^{13}$

6. (10) Animal bones beside vessels nos 1 and 2.

Young swine (subadult): bones of the right forelimb (scapula distal end, humerus, radius, ulna).

Cattle: rib fragments, upper part (6 items), and lower part (7 items) of the rib cage + small rib fragments: at least 4 ribs.

$$
\text { Bird bone (hen? ulna). }{ }^{14}
$$

${ }^{13}$ All the vessels were very poorly preserved, most of the fragments could not be fit together, although the vessels were originally entire.

\author{
${ }^{14}$ The animal bones were determined by László Bartosiewitz. \\ Here we should like to thank him for his work.
}




\section{Grave no. 303}

\section{Grave ditch: feature no. $653=363$}

The short stretch of ditch no. 653 ran along the eastern side of Celtic grave no. 303 but it was not aligned. Only on a short section remained due to a later disturbance. It seems to be the continuation of grave ditch no. 363 running on the other side. Stretch no. 363 was a shallow and vaguely outlined ditch that ran parallel to the longitudinal western wall of grave no. 340. Two oval discolourations were outlined beside the grave but their orientations were different from the direction of the ditch.

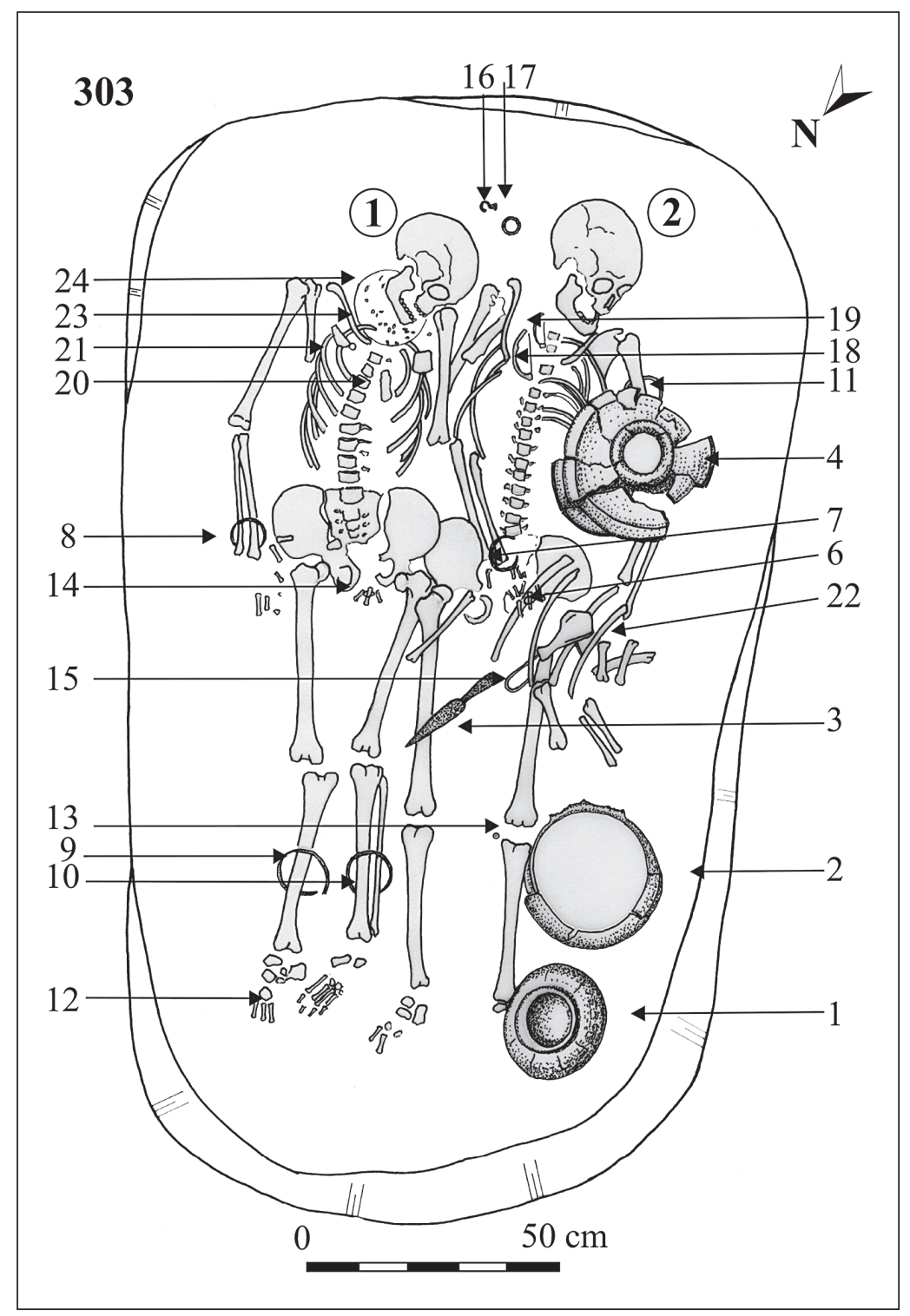

The length of the grave ditch in the east was $4.5 \mathrm{~m}$ outside and $4 \mathrm{~m}$ inside, its width was $25 \mathrm{~cm}$. The western stretch was $4.6 \mathrm{~m}$ outside and $4.2 \mathrm{~m}$ inside, its width was $20 \mathrm{~cm}$. The length of the northern stretch of the ditch was $5 \mathrm{~m}$ outside and $4.4 \mathrm{~m}$ inside and it was $35 \mathrm{~cm}$ wide. On the southern side, the ditch was not preserved.

A multiple superpositions could be observed on the surface around the grave and its ditch. Ditch no. 652 was narrow with a uniform filling and it did not contain finds. This ditch intersected the ditch of grave no. 303 
$(363+653)$. At the same time, ditch no. 652 was intersected by grave no. 362 , which means that the former one was the older.

Shape and measurements of the grave: The grave had trapezoid shape with rounded corners. Its axis was $220 \mathrm{~cm}$ long. Its width was $120-125 \mathrm{~cm}$ in the north and $100 \mathrm{~cm}$ in the south. Its depth measured $60 \mathrm{~cm}$.

The grave was not placed in the centre of the ditch. The ditch was dug along the western wall of the grave, while the axis of the northern stretch of the ditch diverged similarly to that of the eastern stretch. Only a part of the ditch could be observed in the south. The grave appeared on the scraped surface as an oblong discolouration with rounded corners, filled in with slightly grainy brownish grey soil.

Orientation: $\mathrm{N}+245^{\circ}$

Description: Two skeletons an adult female, 35-45 years old (303.1), and an adult male, 40-50 years old $(303.2)^{15}$ lay in the grave with the skulls to the south-west. The two skeletons were extended on the backside by side. The male skeleton (303.2) was $162 \mathrm{~cm}$ long with the face turned to the west. The arms lay along the body. The length of the female skeleton (303.1) was $147 \mathrm{~cm}$ and the face was also turned to the west. The right arm was extended along the body, the left hand was placed on the pelvis of the male skeleton. The bones were medium preserved.

Articles of wear:

A female skeleton (303.1)

1. (23) A bronze chain round the neck, made of small bronze links (Fig. 4.1A). The entwined bronze wire links are of oval and round cross-sections, the closing link is a double ring. (Fig. 4.1B)

2. (23) A bronze pendant beside the chain. A closed, cast ring of a semicircular cross-section closed by a small, plate element on the top, which was cast in one piece. The end of the plate element is broken. (Fig. 4.2)

3. (23) A string of beads beside the bronze chain: 11 hyacinths blue, transparent, biconical, globular and amorphous glass beads, 1 cylindrical amber bead of a cut base, a transparent blue glass bead twisted in spiral coils (Fig. 4.8), 43 amorphous coral and white calcite beads (the latter ones disintegrated when moved). (Fig. 4.3,7)

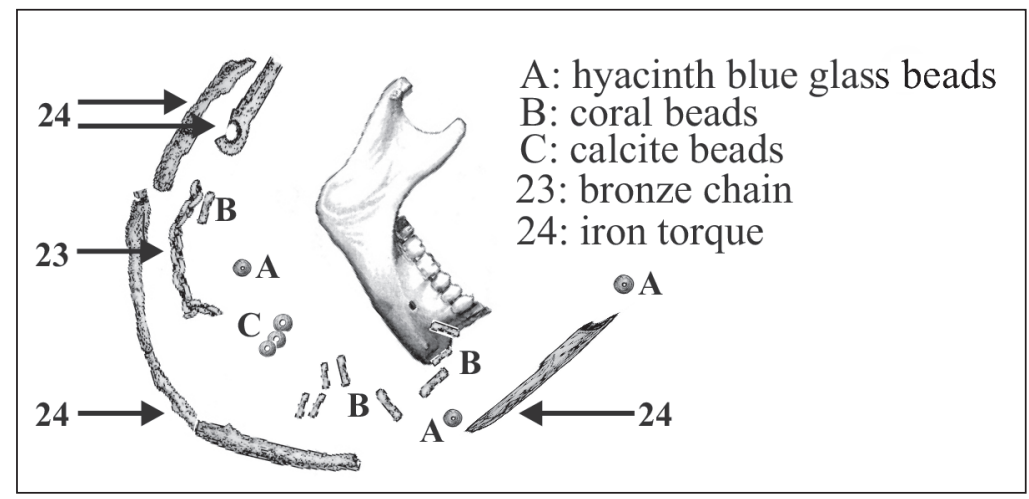

The following items lay between the skulls of the man and the woman towards the wall of the grave.

1. (16) A bronze pendant. It is a cast, closed, circular pendant of round cross-section, with one terminal ending in a funnel-shaped element. (Fig. 4.5)

2. (17). A cast closed bronze ring (probably an element of the necklace of the woman displaced by an animal). (Fig. 4.6)

3. (21) An iron fibula under the right clavicle. It had an external chord, and textile remains at several spots. Length: $4.5 \mathrm{~cm}$. (Fig. 4.9)

4. (20) Fragments of an iron and a bronze chain on the left side of the vertebral column. The bronze chain was made of double oval links. The iron chain was similar but the links rusted together. (Fig. 4.10)

5. (8) A bronze bracelet on the right wrist (the traces of silver plating could still be observed at the excavation), the remains of the cloth of the dress were conserved in the rust. It is an open bracelet with slightly thickening terminals. Its cross-section is octagonal at the terminals and round elsewhere. Diam. $=6 \mathrm{~cm}$. (Fig. 4.12)

${ }^{15}$ Determination of K. Köhler. 
6. (7) A bronze bracelet, similar to the above one, on the left wrist. Diam. $=6 \mathrm{~cm}$ (Fig. 4.11)

7. (10) A bronze anklet of oval cross-section on the bones of the left leg. There is a perforated disc on one terminal, the other terminal is hooked. Diam. $=8.5 \mathrm{~cm}$. (Fig. 4.16)

8. (9) A bronze anklet, similar to the above one, on the right leg. It conserved textile remains. Diam. $=9 \mathrm{~cm}$. (Fig. 4.17)

9. (14) An animal displaced the bones of the fingers and the hand to between the thighbones. Among the bones, there were the fragments of an iron ring of round cross-section. Diam. $=2.4 \mathrm{~cm}$. (Fig. 4.14)

10. (6) A bronze ring of round cross-section on the ring finger of the left hand. It is ornamented with densely incised, ridged patterns. It was not cast in one piece, the open terminals fit closely. Diam. $=2.3 \mathrm{~cm}$. (Fig. 4.13)

11. (5) A hooked, quadrangular iron clasp with a rivet was found in the pelvis. The oblong-shaped body is $3.2 \mathrm{~cm}$ long and $3.8 \mathrm{~cm}$ wide. The bent-up terminals suggest that it was fastened to an approximately $3.2 \mathrm{~cm}$ wide leather belt. (Fig. 4.15)

12. (12) Beads at the bones of the right foot. 4 amber beads of various sizes, 1 biconical large, transparent, turquoise blue glass bead. (Fig. 4.18)

13. (24) An iron torque around the neck beside the bronze chain. It conserved textile remains. The solid, rusted, fragmentary torque is circular in cross-section, the terminals are missing. (Fig. 4.4)

Male skeleton (303.2)

1. (19) Fragment of an iron fibula and its pin on the right clavicle. The foot is missing. (Fig. 5.1)

2. (18) Another iron fibula under the above one (at the lower end of the displaced right clavicle). Length $=10.5 \mathrm{~cm}$, fragmentary, with the chord external. (Fig. 5.2)

3. (11) A bronze bracelet on the left humerus with textile remains. The solid bracelet was bent into waves. Diam. $=8.5 \mathrm{~cm}$. (Fig. 5.9)

4. (13) Traces of an iron object at the left patella. The object has disintegrated.

5. (13) A globular amber bead at the same place. (Fig. 5.3)

6. (15) An iron clamp bent at both terminals lay between the spearhead and the femurs under the cattle bones. Length $=9 \mathrm{~cm}$. (Fig. 5.7)

7. (22) An iron band. One terminal is a perforated disc with a rivet, the other one is returned. It was found outside the left femur, also among the cattle bones. (Fig. 5.6)

\section{Grave furniture:}

8. (3) A spearhead lay across the right femur of the male skeleton no. 2, pointing towards the feet. As suggested from its position, the wooden shaft of the spear was about $70 \mathrm{~cm}$ long or it was broken before being placed in the grave. The length of the spearhead is $25.5 \mathrm{~cm}$, the socket is $4.5 \mathrm{~cm}$ long. Socket diam. $=2 \mathrm{~cm}$. (Fig. 5.13)

9. (4) An urn, broken to pieces, on the left humerus. A rib runs round on the neck under the everted rim. The profile is stepped between the shoulder and the belly. M.d. $=12.5 \mathrm{~cm}$, B.d. $=10 \mathrm{~cm}, \mathrm{H} .=20 \mathrm{~cm}$. (Fig. 5.10 and Fig. 30.3)

10. (2) A larger bowl between the left patella and the wall of the grave. The rim is everted, there is a rib in the arch of the neck, the bottom is omphalos-shaped. M.d. $=23 \mathrm{~cm}$, B.d. $=3 \mathrm{~cm}, \mathrm{H} .=10 \mathrm{~cm}$. (Fig. 5.11 and Fig. 34.4)

11. (1) A smaller urn beside the left ankle bone. The rim is everted, there is a rib on the neck. M.d. $=14 \mathrm{~cm}$, B.d. $=9 \mathrm{~cm}, \mathrm{H} .=18 \mathrm{~cm}$. (Fig. 5.12 and Fig. 31.1 )

12. Cattle ribs and clavicle of on the left hipbone and thigh bone.

Finds recovered from the filling of the grave:

13. 6 hyacinths blue globular and a disk-shaped also hyacinth blue glass bead (Fig. 5.4), 11 amorphous coral beads (Fig. 5.5)

14. The fragment of an iron bracelet also from the filling of the grave. It conserved textile remains in the rust. (Fig. 5.8)

15. Cattle bones beside the skulls.

Vessels and animal bones were found only beside and partly over the male skeleton. 
Grave no. 307

Without grave ditch

Shape and measurements of the grave: The south-eastern, shorter wall was $80 \mathrm{~cm}$ broad, the northwestern wall was more rounded and irregular. It was $55 \mathrm{~cm}$ broad. The longitudinal axis of the grave was $165 \mathrm{~cm}$ in a N-NW-S-SE direction. The grave was $96 \mathrm{~cm}$ deep from the mechanically scraped surface. The western half of the grave was somewhat deeper.

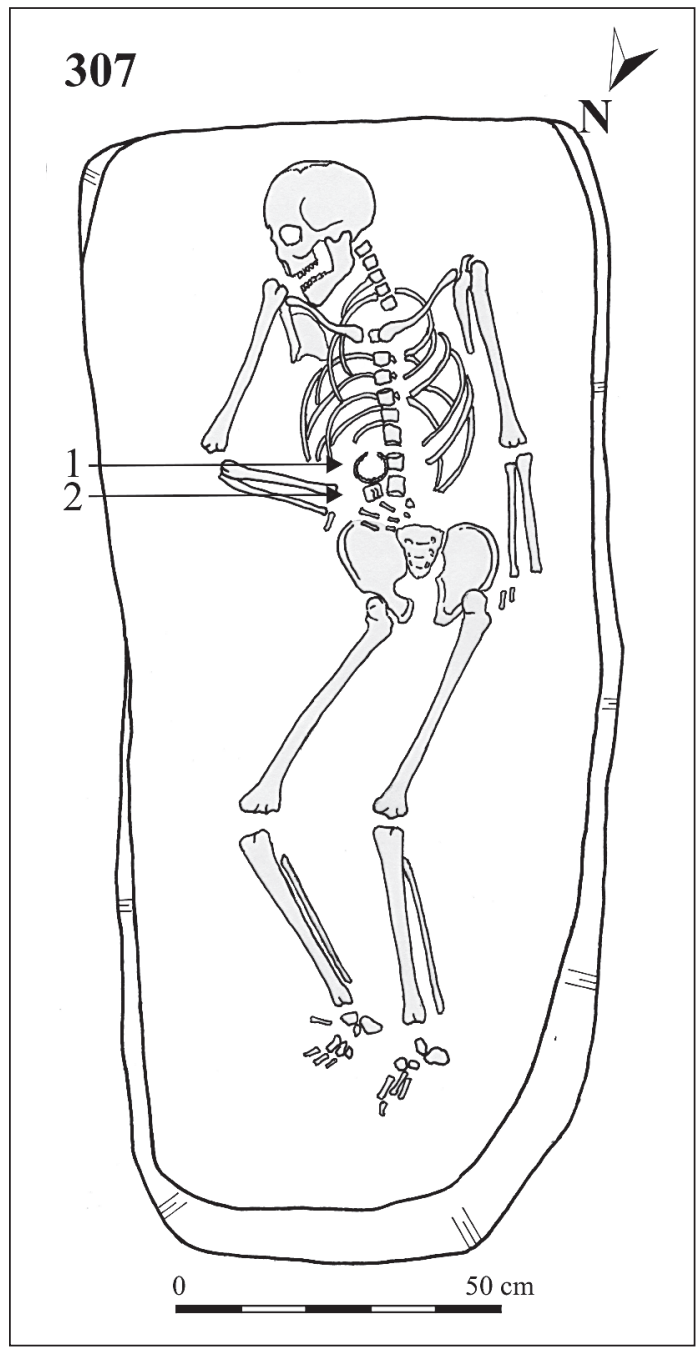

Orientation: $\mathrm{N}+245^{\circ}$

Description: It appeared as a slightly brownish discolouration. The filling of the spot was light brown, grainy, approximately $1 \mathrm{~m} \times 0.5 \mathrm{~m}$ large. A single skeleton lay in the grave in a S-SE-N-NW orientation with the skull to SSE. The bones are medium well preserved. The skeleton was partly extended on the back, the face was turned to the east, the right lower arm was bent over the pelvis, the left arm was extended along the body. The legs were parallelly flexed and turned to the east. Length of the flexed skeleton: $138 \mathrm{~cm}$, skeleton length: $148 \mathrm{~cm}$. Anthropological determination: female, $20-59$ years old. ${ }^{16}$

\footnotetext{
${ }^{16}$ Determination of K. Köhler.
} 


\section{Articles of wear:}

1. (3) A silver ring on the right hand. Closed, cast. In cross-section, it is arched, laminar. Diam. $=2 \mathrm{~cm}$. (Fig. 6.3)

2. (1) A bronze bracelet on the right wrist. The terminals are ridged, open, and seal-shaped. It is plain both inside and out. Diam. $=6 \mathrm{~cm}$. (Fig. 6.1)

3. (2) A quadrangular, hooked iron clasp with a rivet, next to the bracelet. Fragmentary. Length: $3 \mathrm{~cm}$. (Fig. 6.2)

\section{Grave furniture:}

There wasn't any.

\section{Grave no. 340}

\section{Without grave ditch}

Shape and measurements of the grave: It appeared on the scraped surface as an oval discolouration in the yellow fluviatile sand. Its length was $179 \mathrm{~cm}$, its width $91 \mathrm{~cm}$. Its filling was humus with sand grains. The shaft of irregular oval outlines narrowed downwards in the sand keeping a similarly irregular shape. The bottom of the grave was reached at $72 \mathrm{~cm}$ from the mechanically scraped surface. On the bottom, it was $125 \mathrm{~cm}$ long and $50 \mathrm{~cm}$ wide at both the head and the feet.

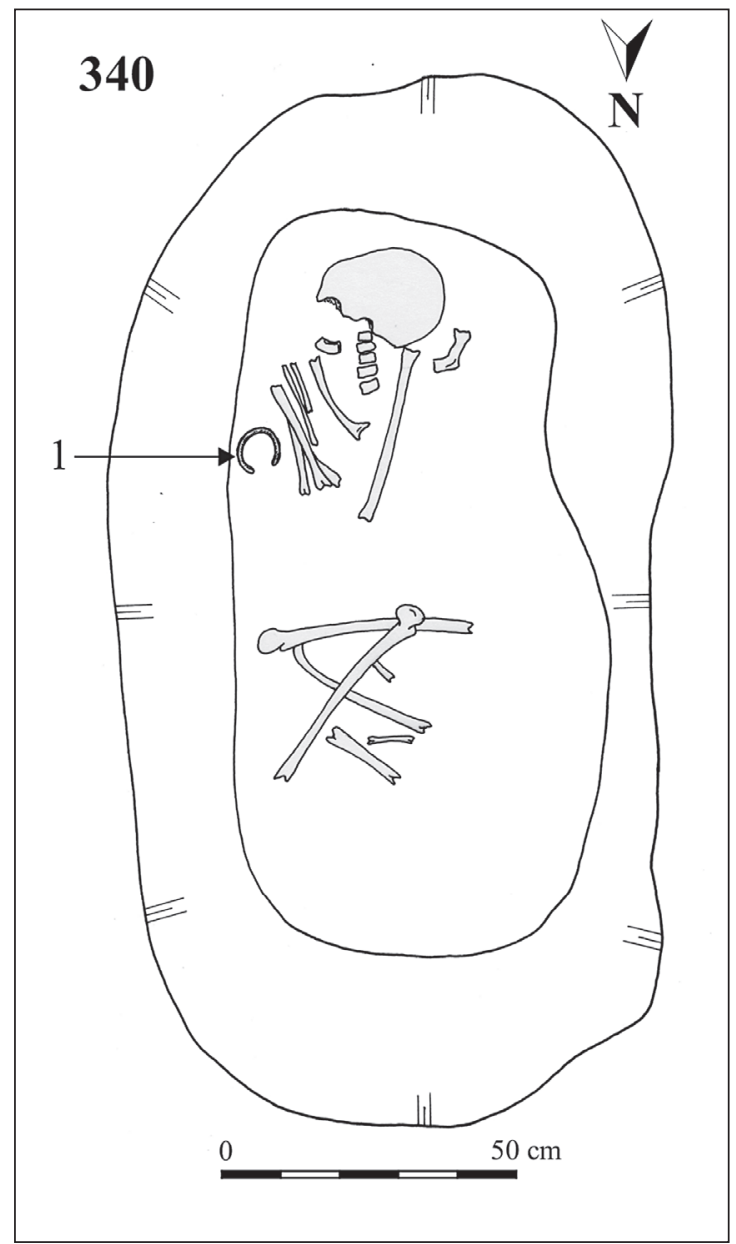

The longitudinal axis of the grave was N-S oriented, it measured $179 \mathrm{~cm}$ when the grave appeared and $125 \mathrm{~cm}$ on the bottom. The maximal width of the grave was max. $90 \mathrm{~cm}$. 
Orientation: $\mathrm{N}+135^{\circ}$

Description: A large, vague, greyish discolouration appeared on the mechanically scraped surface. Scraping the surface deeper, two more discolourations appeared beside grave no. 340 (in a different orientation than the grave!). The irregular one at grave no. 362 yielded neither find material nor bones except for an indeterminable prehistoric sherd at the NW side in the depth of $20 \mathrm{~cm}$. This pit probably belonged to the Early Iron Age settlement that A. Uzsoki had also observed. It could be its last feature toward the west.

Originally, the skull was in the southern end (as suggested by its orientation). The position can only be estimated since the skeleton is very defective. At first glance the grave seemed to have been robbed or violated, the bones of the skeleton, first of all, those of the leg, were replaced in the shaft in a secondary position. The postcranial bones of the adult and the length of the grave suggest, at the same time, that there was not enough space in the grave for a body in an extended position. The arrangement of the long bones indicates that the body was crouched, perhaps on the right side. ${ }^{17}$

Find:

1. A closed iron bracelet of a round cross-section between the right arm and the wall of the grave. Diam. $=5.6 \mathrm{~cm} .($ Fig. 4.13$)$

Grave furniture:

There wasn't any.

Grave no. 342 (Fig. 23)

Without grave ditch

Shape and measurements of the grave: They cannot certainly be told. The grave appeared on the mechanically scraped surface as a very vague, darker brown discolouration in a length of $135 \mathrm{~cm}$ and a width of $40-85 \mathrm{~cm}$.

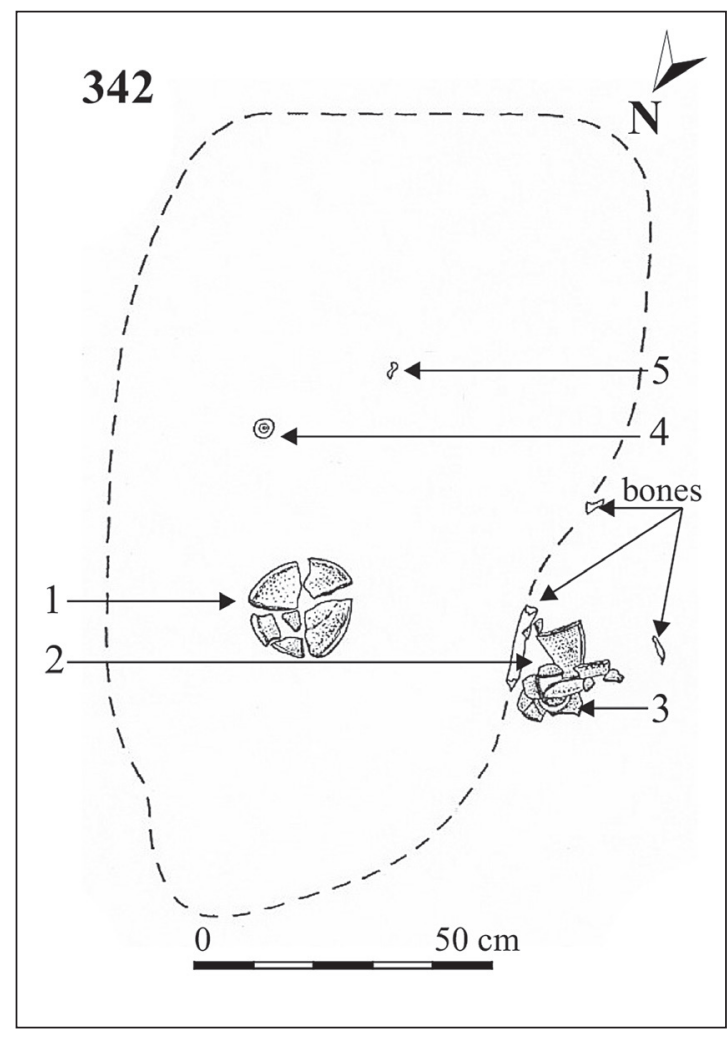

${ }^{17}$ The bones were mixed when the Archaeological Institute's warehouse was soaked. 
Orientation: $\mathrm{N}+226^{\circ}$ (The orientation is only estimated from the straight line of the discolouration accepted as the original wall of the grave.)

Description: A part of the discolouration has disappeared and the yellow stripe of an animal burrow was outlined in the darker brown discolouration. It seemed that the remains of the burial of a woman could be registered on the mechanically scraped surface. It was striking that the graves in the area all appeared deeper than the grave ditches. The bottom of the grave - if the discolouration ever indicated a grave - was higher here than the grave ditches of the neighboring graves Nr. 364 and 360 !

The dead or the remains were placed on the surface or into a very shallow pit and a mound was raised over them. During its clearing, a very shallow pit of NW-SE orientation appeared on a $1.43 \mathrm{~m} \times 0.92 \mathrm{~m}$ large surface filled in with light yellowish mixed soil. The unbroken ground was reached already in the depth of $6 \mathrm{~cm}$. The sherds of the damaged vessel were pressed into the earth, they stood separately as shifted into a secondary position. There was no human skeleton in the grave, only the fragment of a human fibula and a few scattered bone flakes were found. Human bones in a flaky condition could be spotted only in another, $30 \mathrm{~cm} \times 20 \mathrm{~cm}$ large area outside the one described above (they were not charred!). The articles of wear and use and the grave furniture were scattered to a depth of 5-7 cm from the mechanically scraped surface. After the clearing of the grave, a few sherds were found on the bottom, outside the estimated grave pit, together with a few burnt bone flakes. Concerning these latter ones, it cannot be told if they came from humans or animals.

\section{Article of wear:}

1. Two fragments of an iron fibula (?) in the southern part of the discolouration, perhaps the bow and the knob. The remains were so strongly rusted than they crumbled even when they were removed together with the embedding earth.

Article of use:

1. A biconical spindle whorl $20 \mathrm{~cm}$ north of the fibula. ${ }^{18}$

\section{Grave furniture:}

1. The fragment of a so called Linsenflasche among the bones. M.d. $=7 \mathrm{~cm}$, B.d. $=7 \mathrm{~cm}, \mathrm{H} .=18 \mathrm{~cm}$. (Fig. 6.7 and Fig. 32.2)

2. Fragments of a bowl in the centre of the discolouration. It is hemispherical with slightly everted rims, made of coarse clay. M.d. $=14 \mathrm{~cm}$, B.d. $=5 \mathrm{~cm}, \mathrm{H} .=6 \mathrm{~cm}$. (Fig. 6.6 and Fig. 35.6)

Fragments found on the bottom of the grave:

1. The belly fragment of a brick-coloured, wheel-thrown bowl. The exact shape cannot be reconstructed.

2. The belly fragment of a brick-coloured, yellowish, wheel-thrown urn, tempered with sand. The exact shape cannot be reconstructed.

3. Fragment of a vessel between the flask and the bones. The rim is straight and there is a horizontal ridge segmented with finger imprints under the rim. M.d. $=15 \mathrm{~cm}$. (Fig. 6.5)

\section{Grave no. 343/A, 343/B}

Grave ditch: feature 344

The quadrangular grave ditch could not entirely be unearthed since the northern stretch extended under the humus deposition.

The width of the trench varied between $20-40 \mathrm{~cm}$, its depth between $10-20 \mathrm{~cm}$ from the mechanically scraped surface.

The length of the entirely unearthed southern stretch was $5.45 \mathrm{~m}$ long outside and $4.95 \mathrm{~m}$ inside in a width of $30 \mathrm{~cm}$. The western stretch of the ditch was unearthed to a length of $5.75 \mathrm{~m}$ outside and $5.40 \mathrm{~m}$ inside in a width of $35 \mathrm{~cm}$. The eastern one was unearthed to a length of $5.1 \mathrm{~m}$.

Shape and measurements of the grave: The oblong-shaped shaft with rounded corners was $220 \mathrm{~cm}$ long and $130 \mathrm{~cm}$ wide.

Orientation: $\mathrm{N}+240^{\circ}$

Description: The grave was not placed in the axis along the medial line of the area bordered by the western and the eastern stretches of the ditch, it was closer to the western section. The filling of the ditch was greyish

\footnotetext{
${ }^{18}$ It has been lost.
} 


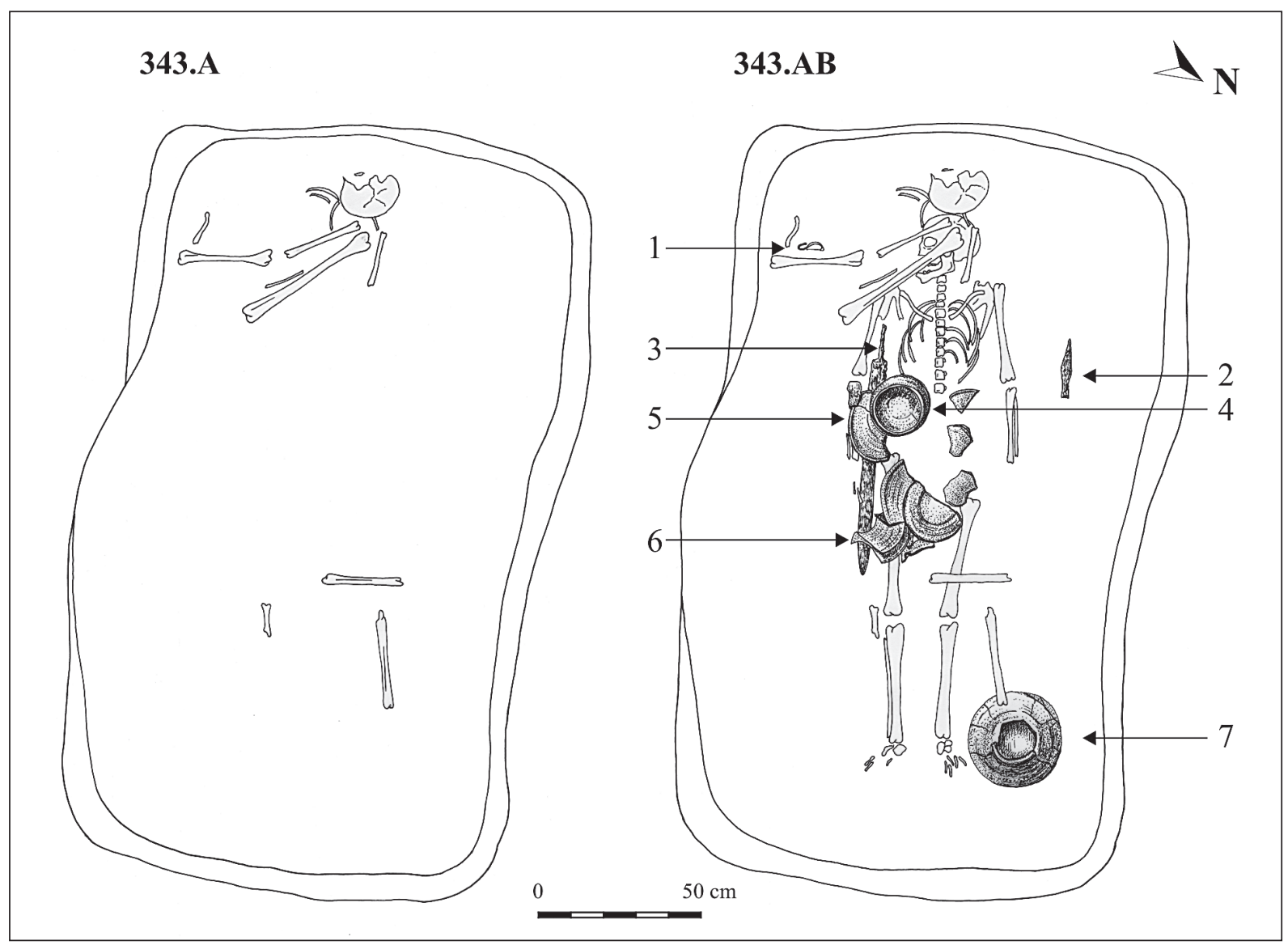

uniform humus, slightly different from the sandy unbroken ground. The grave ditch intersected the eastern stretch of grave ditch no. 346 of the neighbouring grave 345 .

The discolouration with rounded corners and an axis of $\mathrm{N}+198^{\circ}$ orientation appeared with very vague and uncertain outlines within the grave ditch. Five $\mathrm{cm}$ deeper, however, the axis of the grave distinctly showed in a direction diverging $42^{\circ}$ west from the above longitudinal axis. During the excavation, we found that the shaft of a later burial was dug over an earlier grave. The dead buried first (grave 343/A) was disturbed by the second burial (grave 343/B). The bones were probably removed during the digging of the grave and were thrown back into the shaft when the dead in grave B was buried. So the bones lay partly over the body of the second burial in the upper part of the grave. The depth of the grave was $20-24 \mathrm{~cm}$ from the surface where the spot distinctly appeared. The filling at the bottom of the grave was not uniform. In the north-western part of the grave, the second shaft was dug somewhat deeper than the earlier one, which was refilled with darker earth mixed with charcoal grains. The bottom of the intact part of the first grave was found only in an area of a diameter of about 65-70 cm on the NE side. During the second burial, the wall of the grave fell in at some places, which appeared at the excavations as a somewhat looser, crumbling soil, a shade darker than its environment.

\section{Grave 343/A}

The long bones and the skull lay in the southern part of the grave. The position of the bones suggests that a long time must have passed between the first and the second burials. Two long bones were found across the left thighbone of skeleton $\mathrm{B}$, and outside the left leg bone. The top of the skull of skeleton A faced $\mathrm{N}$ and was thrown back, together with the earth, at the time of the second burial on top the skull of skeleton B. The fragments of the arm and the ribs lay under it. It can be judged from the position of the bones that the bones of the arms were yet 
held together by the ligaments when they were thrown back into the grave. Anthropological determination: female, 20-30 years old man(?). ${ }^{19}$

It cannot be told which articles and which grave furniture could have belonged to this burial. We only suppose from the position that the fragment of the large iron object, outlined by rust, noted between the bones thrown back in the shaft at the northern corner of the grave, could belong to this burial together with the broken vessels (not by the weight of the earth!).

Article of wear:

1. (1) Bronze fibula, in the south corner of the grave..$^{20}$

\section{Grave 343/B}

The grave shaft only slightly diverged from the shaft of grave 343/A. The skeleton lay in it with the skull to S-SW. The body was extended, the bones of the right hand and partly those of the lower arm were missing. The bones were poorly preserved. Anthropological determination: male(?), 20-30 years old. ${ }^{21}$

\section{Articles of wear:}

1. (12) The fragment of a small link of a round cross-section from a bronze chain was found in the skull during cleaning. (Fig. 7.1)

\section{Weapons:}

1. (2) A midribbed iron spearhead pointing towards the head was found in the height of the left lower arm and the elbow, $20 \mathrm{~cm}$ toward the western wall of the grave. Its length is $15.5 \mathrm{~cm}$, the socket is $5 \mathrm{~cm}$ long, the diameter is $2 \mathrm{~cm}$. (Fig. 7.2)

2. (3) An iron sword between the right upper arm and the breast bone (damaged, length: $73 \mathrm{~cm}$ ). The pommel is disc-shaped, ${ }^{22}$ and there is a suspension mount on the upper part of the scabbard. Facing the suspension mount, finely woven textile was found on the scabbard. The chape is arched, two small rivets fastened it to the scabbard. Both the scabbard and the blade are midribbed. The width of the blade is $5.2 \mathrm{~cm}$. The edges of the scabbard are broken. Length of the hilt: $12 \mathrm{~cm}$. Each rivet of a hemispherical head can be found on the two sides of the chape. Another rivet with a hemispherical head can be observed $7.4 \mathrm{~cm}$ from the above ones, in the axis of the scabbard above the chape. (Fig. $7.4 a-4 b$ )

3. (-) Little iron fragment, near to the sword. (Fig. 7.3)

\section{Grave furniture:}

The vessels placed into the graves cannot be separated. It was probably the intact vessels that belonged to the second burial and the broken ones must have belonged to the grave furniture of the first burial, which were broken at the time of the second burial.

1. (7) A large, broken urn at the left foot. There is a rib in the arch of the neck under the everted rim. M.d. $=14 \mathrm{~cm}$, B.d. $=10 \mathrm{~cm}, \mathrm{H} .=23 \mathrm{~cm}$. (Fig. 8.4 and Fig. 31.4)

2. (5) A shallow bowl on the sword, on the right hipbone. It is a simple vessel with an inverted rim and cut bottom. (Fig. 8.2)

3. (6) A bowl, broken to pieces, was found partly beside the above bowl on the sword and partly on the right thighbone and hipbone. The rim is everted and two parallel grooves run in the arch of the neck. M.d. $=21 \mathrm{~cm}$, B.d. $=4 \mathrm{~cm}, \mathrm{H} .=8 \mathrm{~cm}$. (Fig. 8.1 and Fig 33.1)

4. (4) An urn, broken to pieces, was found between the thighbones. The rim is everted, there is a rib in the arch of the neck and two grooves on the shoulder. M.d. $=14 \mathrm{~cm}$, B.d. $=10 \mathrm{~cm}, \mathrm{H} .=20 \mathrm{~cm}$. (Fig. 8.3 and Fig. 31.5)

\section{Double burial no. 345/A, 345/B}

Grave ditch: feature 346

There is an approximately $20 \mathrm{~cm}$ wide ditch around the grave on the SE and SW sides, which was intersected by the adjacent grave ditch no. 344. The NE and NW sides could not be seen in the whole length, on the NW side, it stretched under the humus depot at the edge of the cutting. The southern ditch was $5.25 \mathrm{~m}$ long outside and $4.5 \mathrm{~m}$ inside, its width measured $25 \mathrm{~cm}$. The unearthed part of the western section was $3.5 \mathrm{~m}$ long outside and $3.25 \mathrm{~m}$ inside in a width of $30 \mathrm{~cm}$. The eastern section of the grave ditch was destroyed at the digging of grave ditch no. 344 .

\footnotetext{
${ }^{19}$ Determination of K. Köhler.

${ }^{20}$ It was destroyed during restoration.
}

\footnotetext{
${ }^{21}$ Determination of K. Köhler.

${ }^{22}$ It was destroyed during restoration.
} 
Shape and measurements of the grave: The elongated, oval grave appeared as a darker brown discolouration (345/B). Downwards, the oblong shape of the shaft with rounded corners was filled in with a mixed brown soil with some infiltrated yellow. At the scraping of the oval spot, the pit of the second burial got outlined: its length was $235 \mathrm{~cm}$, its width was $115 \mathrm{~cm}$ in the south, and $105 \mathrm{~cm}$ in the north. The discolouration of the earlier grave appeared somewhat deeper, and it somewhat diverged from the axis of the later shaft toward the west. This one was $245 \mathrm{~m}$ long and $130 \mathrm{~m}$ wide in the south and $115 \mathrm{~cm}$ wide in the north.

Orientation: $345 / \mathrm{B}: \mathrm{N}+234.5^{\circ}$

Description: The few bone splinters that appeared during scraping already indicated more than one burial. Grave ditch 346, nevertheless, was not dug again at the burial in grave no. 345/B, which means that the ditch of the earlier grave could still be seen at the time of the second burial although the grave itself had already disappeared.

Burial no. 345/A1-A2 (double, contemporary burial)

The depth of the grave varied between 46 and $57 \mathrm{~cm}$ slightly deepening eastwards in the whole length of the grave. The filling of the grave was darker than that of the second one dug over it.

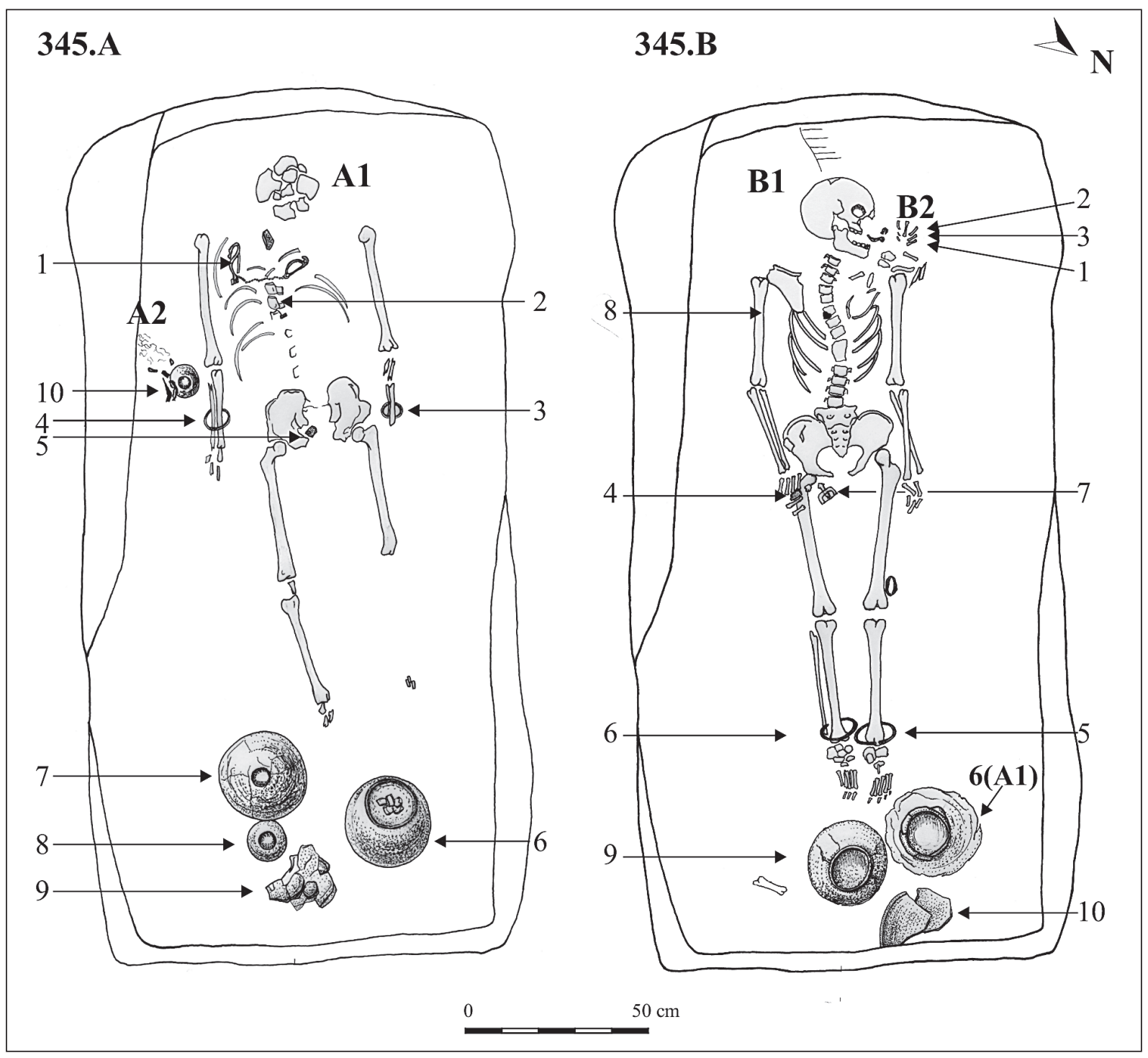

Acta Archaeologica Academiae Scientiarum Hungaricae 71, 2020 


\section{Skeleton no. 345/A1:}

Description: The skeleton of an adult on the back in an extended position. Anthropological determination: male (?), 23-39 years old. ${ }^{23}$

The bones of the left leg are missing. The grave was damaged probably by the later burial. This is suggested by the fact that some of the tarsals stayed in place. The arms were extended along the body. The widely apart legs, the flattened pelvis, and the position of the bones of the chest are characteristic of a fat person. The skull was cracked. The bones of the skull and the chest were fragmentary.

The measurable length of the skeleton was $155 \mathrm{~cm}$.

\section{Articles of wear:}

Two bronze fibulae joined by a chain lay on the breastbone.

1. (1) Fragment of a bronze fibula on the left side of the chest (Dux-type). The beaded and ridged foot was returned on the bow, it is broken, only the returned section is preserved. The fibula has an external chord and the last link of the chain was fastened to the chord. (Fig. 10.1)

2. (1) An intact bronze fibula on the right side of the chest. (Perhaps Predux-type) It was a one-piece fibula with the chord external. The beaded and ridged end of the foot is returned on the bow. Here it is of round section. The bow is ridged, two ridges along the length of the bow are beaded. The beading at the end of the foot encloses two panels, originally both used to hold enamel insets. Now only one shows the remains of white enamel. The closing link of the chain was fastened to the chord. Length: $10 \mathrm{~cm}$. (Fig. 10.2)

3. (1) The bronze chain that joins the above two fibulae. The chain was made of double circular links, which are $4 \mathrm{~mm}$ in diameter. At the two terminals, open bronze rings fasten the chain to the fibulae. Their diameters are $1.3 \mathrm{~cm}$ and $1.6 \mathrm{~cm}$. (Fig. 10.1-2)

4. (4) An open bronze bracelet, broken into two, on the right wrist. It is plain, solid, and cast, oval in crosssection. Diam. $=6 \mathrm{~cm}$. (Fig. 10.4)

5. (3) A bronze bracelet, similar to the above one, on the left wrist. The terminal broke off. Diameter: $5.5 \mathrm{~cm}$. (Fig. 10.3)

6. $(2,5)$ An iron clasp on the right side of the pelvis. The body of the clasp lay in the right, the lower part of the pelvis, the hook was displaced higher to the vertebral column during the second burial. Length of the clasp body: $2 \mathrm{~cm}$, width $2.8 \mathrm{~cm}$. It belonged to a $2.4 \mathrm{~cm}$ wide leather strap. (Fig. 10.6)

\section{Grave furniture:}

1. (6) An urn between the legs, between the feet and the wall of the grave. The rim is everted, and there is a rib in the arch of the neck and a groove around the shoulder. M.d. $=14 \mathrm{~cm}$, B.d. $=10 \mathrm{~cm}, \mathrm{H} .=19 \mathrm{~cm}$. The rim of the urn already appeared on the bottom of the grave B at the excavation of the latter one. (Fig. 10.8 and Fig. 31.2)

2. (7) A wheel-thrown $\boldsymbol{b o w} \boldsymbol{l}$ with the mouth turned down between the right foot and the wall of the grave. M.d. $=23 \mathrm{~cm}$, B.d. $=4 \mathrm{~cm}, \mathrm{H} .=8 \mathrm{~cm}$. (Fig. 10.5)

3. (8) A cup at the foot. The rim is slightly everted, the bottom is omphalos-shaped. M.d. $=8 \mathrm{~cm}$, B.d. $=2 \mathrm{~cm}$, H. $=5.5 \mathrm{~cm}$. (Fig. 10.9 and Fig. 35.3)

4. (9) An urn at the foot between the cup and the northern wall of the grave. It is dark grey, light grey in breakage, broken to pieces. B.d. $=12.5 \mathrm{~cm}$. (Fig. 10.7)

Skeleton no. 345/A2:

Description: Cremation burial with scattered ashes beside the right arm of skeleton A.1, toward the eastern wall of the grave. The ashes and the charred bones were scattered on a surface of about $20 \mathrm{~cm} \times 10 \mathrm{~cm}$. No separate pit could be identified and neither burial seemed to be above the other. This implies that the two burials took place at the same time.

\section{Article of wear:}

1. (10) The fragment of a bronze fibula beside the ashes. (Perhaps Pre-Duchov-type) It is small, the spring is damaged, only a fragment of the pin survived. The returned end of the foot is four times beaded. $\mathrm{H} .=5 \mathrm{~cm}$. (Fig. 10.11)

\footnotetext{
${ }^{23}$ Determination of Zsuzsa Zoffmann. Bones have since been lost. 


\section{Grave furniture:}

1. (10) A cup north-west of the ashes, partly on them. The bottom is omphalos-shaped. M.d. $=8 \mathrm{~cm}$, B.d. $=4 \mathrm{~cm}$, H. $=5.5 \mathrm{~cm}$. (Fig. 10.10 and Fig. 35.1 )

\section{Burial no. 345/B (double, contemporary)}

Description: A small, intact, brown, wheel-thrown flask stood, somewhat inclined, in the NW end of the grave shaft much higher than the skeleton.

The extended skeleton of a woman lay on the back (345/B1), with an intact vessel at the foot. The skull turned to the left, the lower part of the orbits, the nasal bone and the frontal part of the facial skull were missing. The sharp edges of the bones suggest cutting. Female (?) 30-40 years old. ${ }^{24}$ The remains of a child were found beside the skull, on the left side, in the place or under the missing facial skull (345/B2). The cremated children neonatus, Infans I. 0.5-5.5-year-old.

The traces of calcification(?), deformities could be observed on the vertebral column of the adult. The pelvis was very wide as if fallen apart during the delivery of a child. The right foot was turned awry, the ankle was on top. The feet were closed, the right hand rested on the upper part of the right thigh bone.

\section{Articles of wear:}

1. (1) A two-piece, incised, so-called bird head bronze fibula with a rosette on the returned foot. The pin is missing. H. $=4.5 \mathrm{~cm}$. (Fig. 9.1) The fragment of the spring of the fibula was removed by some burrowing animal into the filling of grave no. 345/A1

2. (2) A zoomorphic bronze fibula with stylized griffin head under no. 1. The end of the foot imitates an animal. Bunches of lines, grooved obliquely at a right angle, cover the bow on the two sides of the central ridge in five bands. It is a one-piece fibula with the chord external. H. $=5.5 \mathrm{~cm}$. (Fig. 9.3)

3. (8) A pointed, very rusty iron pin on the right side of the skeleton, on the fourth cervical vertebra. Its trace could be observed on the vertebra. The pin is fragmentary, it is round in cross-section. (Fig. 9.2)

4. (4) A bronze ring on the middle finger of the right hand. The open ring was made from a wire of round cross-section. Diam. $=2.3 \mathrm{~cm}$. (Fig. 9.5)

5. (5) A bronze, solid, so-called sleeved anklet of round cross-section on the left ankle. One terminal is funnel-shaped and hollow, the other ends in a rod. Diam. $=8 \mathrm{~cm}$. (Fig. 9.6)

6. (6) A similar bronze anklet on the right ankle. Diam. $=7.7 \mathrm{~cm}$. (Fig. 9.7)

7. (7) A hooked iron clasp with an angular body under the caput femoris of the right thighbone. The tongue is fastened to the body by a rivet. $\mathrm{L} .=2.5 \mathrm{~cm}, \mathrm{~W} .=4.3 \mathrm{~cm}$. The width of the strap was $3.8 \mathrm{~cm}$. (Fig. 9.4)

\section{Grave furniture:}

1. (10) Fragments of a wheel-thrown $\boldsymbol{b o w} \boldsymbol{l}$ with inverted rim were found at the end of the grave next to the wall of the grave shaft. The bottom is omphalos-shaped. M.d. $=15 \mathrm{~cm}$, B.d. $=3 \mathrm{~cm}, \mathrm{H} .=7 \mathrm{~cm}$. (Fig. 8.6 and Fig. 35.4)

2. (9) An intact, wheel-thrown, brownish grey urn under the level of the skeleton, between the feet and the northern, short wall of the grave. M.d. $=10 \mathrm{~cm}$, B.d. $=9 \mathrm{~cm}, \mathrm{H} .=16.5 \mathrm{~cm}$. (Fig. 8.5 and Fig. 35.7)

3. A little animal bone was in the remains of the children.

\section{Grave no. 347}

\section{Grave ditch: feature no. 359}

The ditch was barely visible. It encircled only the eastern part of the grave in a U-shape. Its width was approximately $30-35 \mathrm{~cm}$. There was a huge thunderstorm with heavy rain during its excavation. After the thunderstorm, the surface was scraped again but the ditch could not be observed any more either on the eastern part of the grave or from the middle of the southern part parallelly to the edge of the grave. Only a section of the western ditch appeared the northern stretch was missing, the eastern stretch was $5.6 \mathrm{~m}$ long outside and $5 \mathrm{~m}$ inside in a width of $35 \mathrm{~cm}$. The southern stretch measured $5.8 \mathrm{~m}$ outside and $5.6 \mathrm{~m}$ inside, its width was $40 \mathrm{~cm}$, its depth $6 \mathrm{~cm}$.

Ditch no. 359 was intersected by ditch no. 299 , which means that grave ditch no. 359 was dug earlier than ditch no. 299.

Orientation: $\mathrm{N}+228^{\circ}$

\footnotetext{
${ }^{24}$ Determination of K. Köhler.
} 
Shape and measurements of the grave: Length $240 \mathrm{~cm}$. The width on the south-eastern side was $150 \mathrm{~cm}$, and $100 \mathrm{~cm}$ on the north-western side. Depth from the mechanically scraped surface: $62 \mathrm{~cm}$.

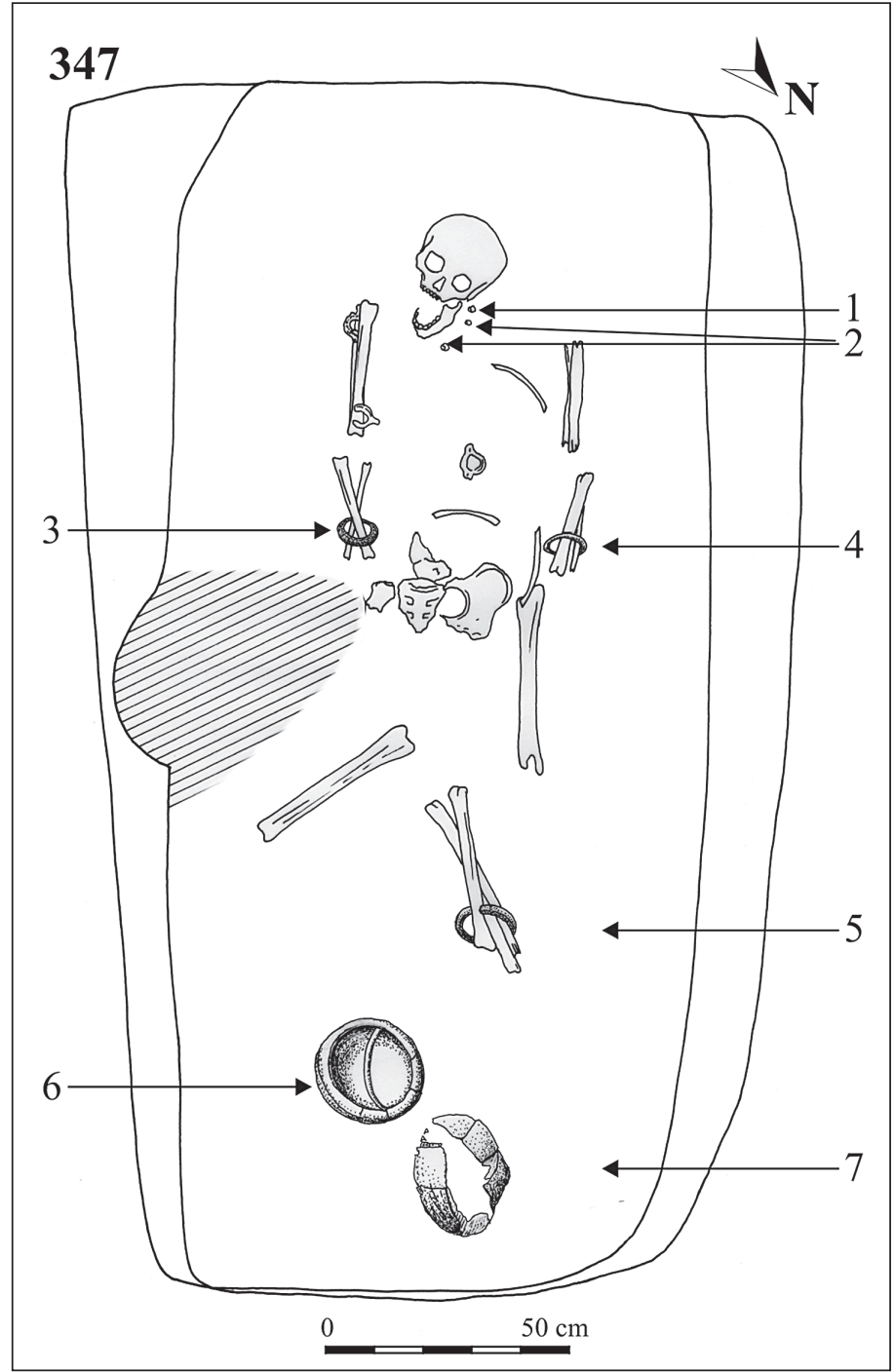

\section{Description:}

A $60 \mathrm{~cm} \times 75 \mathrm{~cm}$ large light brown discolouration could be seen beside the grave shaft. It did not contain any material and its edges were not clear either. The walls of the grave shaft were irregular as if two graves had been dug one over the other. The shaft and partly the level of the skeleton were disturbed by an animal burrow, which ran into the shaft at the N-NE wall and disturbed the burial at the right thigh bone and at the chest, where the bones were removed from their original position. The filling of the shaft was dark brown, mixed, the outlines were less regular than those of the neighbouring graves. The bones of the skeleton of a woman extended on the back were poorly preserved. The length of the skeleton was about 140-142 cm. The entire chest of the skeleton was missing, neither the ribs nor the vertebrae survived. The skull turned to the right. The arms were extended along the body. The right thighbone fell from the socket, the leg bones were crossed. The metal finds were also poorly preserved, they crumbled during the clearing of the grave. There were three vessels at the feet of the skeleton. An animal burrow could be seen in the wall in the middle of the grave, this could remove the bones and disrupt the middle part of the skel- 
eton. During the clearing of the grave, iron fragments were found in the animal burrow and under the skull. Anthropological determination: female, $30-40$ years old. ${ }^{25}$

Finds:

1. The fragments of two iron plates (clasps?) were found in the filling of the grave in the uppermost $20 \mathrm{~cm}$. One was flat, the other had a slightly oval cross-section. (Fig. 11.9-10)

Articles of wear:

1. (1-2) Red, irregular coral beads left of the skull. (Fig. 11.1) Each a round amber bead without base was found under it and the jaw. (Fig. 11.2) Further beads were found during the cleaning of the skull: 1 transparent, white, amphora-shaped glass bead and 3 round amber beads without bases in various sizes. (Fig. 11.3) Some more beads were found under the chest at the picking up of the skeleton: 3 amber beads without bases of various sizes, 1 hemispherical amber bead, and a flat disc-shaped amber bead. (Fig. 11.5)

2. (3) A bronze bracelet on the right wrist. The open bracelet is twice segmented by ridges and engraved lines. Densely engraved oblique lines decorated the barrel-shaped swollen part. Sleeved type. Diam. $=6.2 \mathrm{~cm}$. (Fig. 11.7)

3. (4) A bronze bracelet on the left wrist. The open bracelet is twice segmented by ridges and engraved lines. Densely engraved oblique lines decorated the barrel-shaped swollen part. It is the pair of the above one. Diam. $=6.2 \mathrm{~cm}$. (Fig. 11.6)

4. (5) A bronze anklet on the left ankle (its pair was removed by the animal). It is round in cross-section, hollow and sleeved. Diam. $=8.7 \mathrm{~cm}$. (Fig. 11.8)

5. The fragment of a small iron object under the skull. (Fig. 11.4)

Grave furniture:

1. (6) A $\boldsymbol{b o w l}$ on the feet. M.d. $=24 \mathrm{~cm}, \mathrm{H} .=8 \mathrm{~cm}, \mathrm{~B} . \mathrm{d} .=1 \mathrm{~cm}$. The bottom is omphalos-shaped, the rim is everted. There is a rib in the arch of the neck, its colour is brownish-black in consequence of being baked in a reducing environment. (Fig. 11.12)

2. (6) Another bowl in the above one. It has a similar colour, it is fragmentary, the bottom is missing and there are two grooves in the arch of the neck. M.d. $=26 \mathrm{~cm}$, B.d. $=$ unmeasurable, H. $=7.6 \mathrm{~cm}$. It had been on top of the smaller bowl with the mouth down, later it got pressed into it. (Fig. 11.11)

3. (7) Broken vessels between the bowl and the northern short wall of the grave: an urn with everted rim, a groove on the shoulder. It is matt and grainy, tempered with some sand. M.d. $=7.5 \mathrm{~cm}$. (Fig. 11.14)

4. (7) The fragment of another urn among the sherds. It is brownish black, and there are two grooves on the shoulder. It cannot be measured. (Fig. 11.13)

\section{Grave no. 348}

Without grave ditch

Shape and measurements of the grave: The oblong-shaped grave shaft had rounded corners at the southern shorter wall, rectangular ones at the northern wall. The longitudinal axis was $195 \mathrm{~cm}$ long, the width was $83 \mathrm{~cm}$ at the southern part and $75 \mathrm{~cm}$ at the northern one, its depth was $20 \mathrm{~cm}$.

Orientation: $\mathrm{N}+226^{\circ}$

Description: The very poorly preserved skeleton of a woman lay in the depth of $16 \mathrm{~cm}$. The bones of the chest and the pelvis were missing similarly to the bones of the hand and the foot. The remaining bones were very poorly preserved. The skeleton was extended on the back and slightly turned to the right, both the arms and the legs were bent slightly to the right. Even the facial skull was turned to the right. The legs were slightly raised at the knees. The length of the skeleton was $150 \mathrm{~cm}$, the length of the flexed skeleton was $142 \mathrm{~cm}$. Anthropological determination: female? $20-\mathrm{x}$ years old. ${ }^{26}$

Articles of wear:

1. (1) A two-piece bronze torque around the neck. It consists of two wires of round cross-section. The terminals are bent into hooks and interlocked. (Fig. 12.1) 


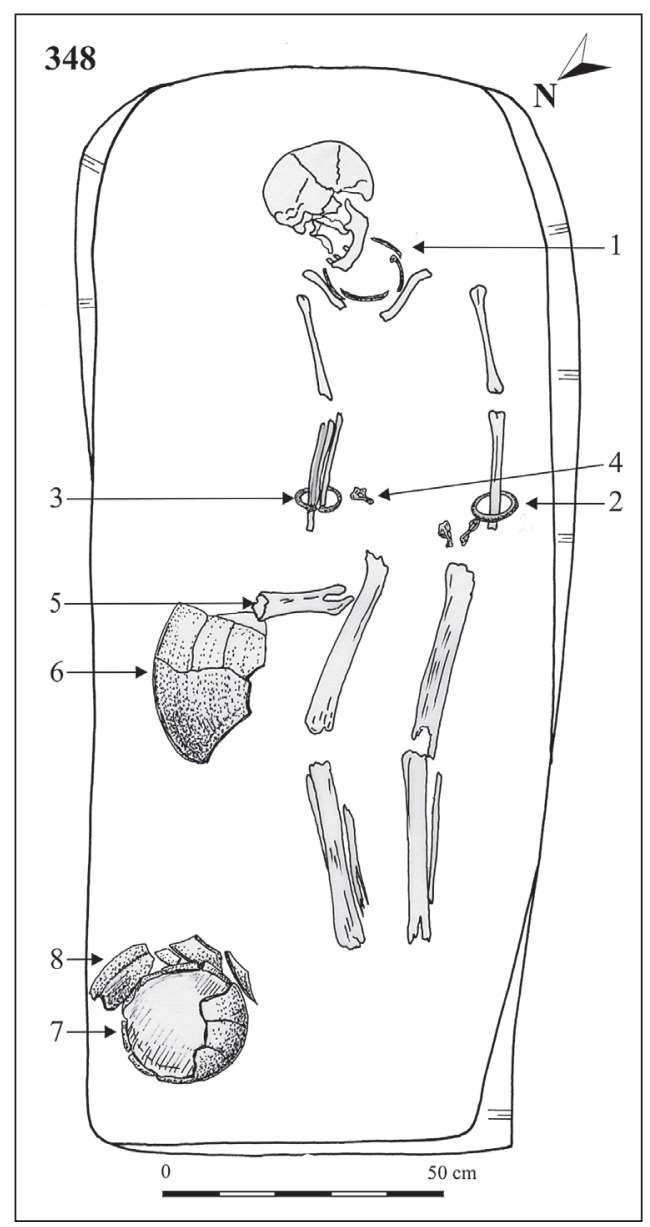

2. (3) A bronze bracelet on the right wrist. It has open terminals, one terminal slightly widens and overlaps the other, both are ridged. It is solid and round in cross-section. Diam. $=5.8 \mathrm{~cm}$. (Fig. 12.3)

3. (2) A bronze bracelet on the left wrist. It has open terminals, one terminal slightly widens and overlaps the other, both are ridged. It is solid and round in cross-section. Diam. $=5.8 \times 5 \mathrm{~cm}$. (Fig. 12.2)

4. (4) Fragment of the hook of an iron clasp between the left wrist and the pelvis. (Fig. 12.4)

Grave furniture:

1. (6) The fragment of a large bowl outside the right thigh bone. It is brownish, spotted with grey, wheelthrown, perforated under the rim beside the breakage. It shows traces of horizontal smoothing. M.d. $=18 \mathrm{~cm}$, B.d. $=6 \mathrm{~cm}, \mathrm{H} .=12 \mathrm{~cm}$. (Fig. 12.5 )

2. (7) Fragments of an urn in the north-eastern corner of the grave. It was tempered with sand and spotted from the baking. B.d. $=16 \mathrm{~cm}$. (Fig. 12.7 and Fig. 35.9)

3. (8) The fragments of a smaller $\boldsymbol{b o w l}$ on the urn. Originally it was placed on the mouth of the urn with the mouth up. The wheel-thrown vessel has an everted rim and a rib in the arch of the neck, the bottom is omphalosshaped. M.d. $=25 \mathrm{~cm}$, B.d. $=5 \mathrm{~cm}, \mathrm{H} .=9 \mathrm{~cm}$. (Fig. 12.6 and Fig. 34.5)

4. (5) An animal bone, probably pig, between the right thighbone and the large bowl.

Graves 350/A - 350/B

Grave ditch: feature no. 349

A quadrangular grave ditch with rounded corners. The western stretch was entirely excavated. Here it was $5.20 \mathrm{~m}$ long and $40 \mathrm{~cm}$ wide, the inside length of the stretch was $4,75 \mathrm{~m}$. The northern stretch could be followed to a length of 3.60-3.70 m, where the inside length measured $3.20 \mathrm{~m}$. The southern stretch was $4.50 \mathrm{~m}$ long outside 
until the corner, where its width was $40 \mathrm{~cm}$, the inner length was $4.20 \mathrm{~m}$. At this point, it broke in an obtuse angle. The reconstructed original shape is somewhat irregular and the grave was not placed in the medial axis of the ditch. The ditch could be observed in a width of about $25 \mathrm{~cm}$ on the scraped surface with an interruption at the northern corner. The average width was $28-30 \mathrm{~cm}$, the depth was $8-10 \mathrm{~cm}$. In cross-section it was semicircular, and it was filled in with greyish, uniform humus. The continuation of the ditch on the northern side could not be observed, it was intersected by ditch no. 351 . Only a $40 \mathrm{~cm}$ long stretch could be seen from the eastern part of ditch no. 349 . Here ditch no. 351 of grave no. 301 intersected it once more.

Orientation (350/A): $\mathrm{N}+234.5^{\circ}$

Shape and measurements of the grave: The second burial disturbed grave no. $350 / \mathrm{A}^{27}$

Description: A discolouration that seemed unusually long and had an average width appeared along the axis in the centre of grave ditch no. 349 against the dark soil. It was light yellow at the edges and mixed in the centre. During its excavation, the original edges of the shaft were outlined both in cross-section and on the surface,

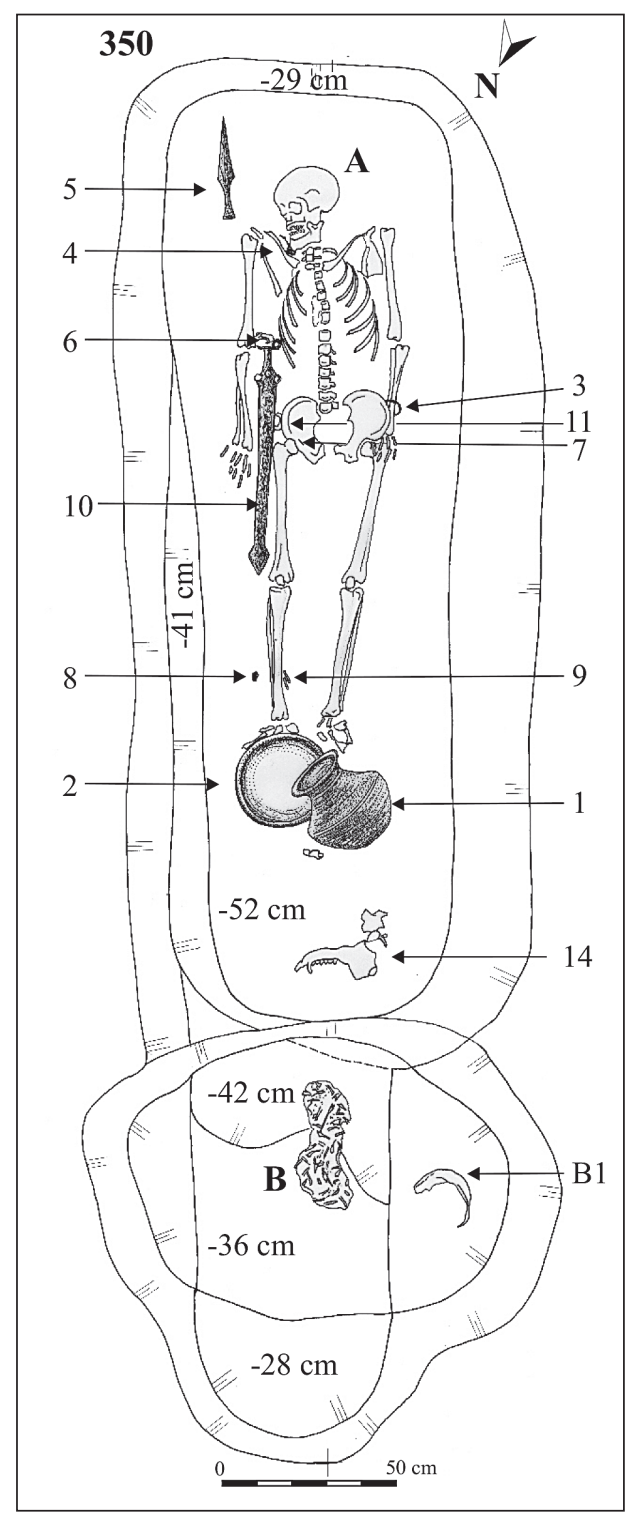

${ }^{27}$ The measurements see at the description of the burial. 
together with the traces of a later pit at the northern end. Based on the colours the later pit appeared with a blackish grey filling in the middle and southern part of the narrow grave and extended westwards. The extremely soft filling of the shaft was strongly mixed sand with humus patches. The later pit in the northern part of the discolouration was different, here the heap of charred bones appeared in the hard, yellow loess in one block (scattered ashes of burial no. 350/B). The ground was very hard above and around the charred bones. Next to the charred bones some weathered, poorly preserved black-and-red sherds with black breakage were found. The vessel stood above them.

Measurements of the grave: The length of the discolouration on the scraped surface was $390 \mathrm{~cm}$, its width was $100 \mathrm{~cm}$ and $90 \mathrm{~cm}$. It could be observed during the excavation that the pit of cremation burial no. 350/B caused the disproportion. The discolouration of grave 350/A was $260 \mathrm{~cm}$ long on the scraped surface. A bench appeared on the southern side in the depth of $29 \mathrm{~cm}$. The same bench could be observed on the northern side as well although only in a short, $10 \mathrm{~cm}$ wide section. The bottom of the cremation burial (350/B) was found in a depth between 42 $\mathrm{cm}$ and $36 \mathrm{~cm}$. At the inhumation grave, black soil mixed with loess, the filling of the shaft, appeared behind the slightly slanting, sandy bench between $41-43 \mathrm{~cm}$ next to the eastern wall of the shaft. This discolouration was oblong-shaped with rounded corners in the south. Its length was $210 \mathrm{~cm}$, its width measured $50 \mathrm{~cm}$ in the north.

\section{Burial no. 350/B}

\section{Description:}

A round pit disturbed the inhumation grave in the north-western part of the shaft. It was a cremation burial with scattered ashes, which was younger than inhumation grave no. 350/A, as revealed by the overlapping outlines.

A very poorly preserved broken vessel was found above the ashes. The ashes appeared already in the depth of $28 \mathrm{~cm}$, but most of the charred bones lay on the bottom of the pit in the depth of $42 \mathrm{~cm}$. Here the bottom of the grave reached the yellow sand.

\section{Grave furniture:}

1. A large urn tempered with coarse, grainy sand. B.d. $=12 \mathrm{~cm}$. It was secondarily burnt. $(\text { Fig. 12.12 })^{28}$

2. (2) A handmade $\boldsymbol{b o w} \boldsymbol{l}$, which was also secondarily burnt. It is black with red spots and broken to pieces. M.d. $=22 \mathrm{~cm}$, B.d. $=14 \mathrm{~cm}, \mathrm{H} .=11 \mathrm{~cm}$. It is distorted. (Fig. 12.11)

\section{Inhumation burial no. 350/A}

Shape and measurements of the grave: An oblong-shaped shaft with rounded corners. The later pit damaged the length of the grave in the north along the axis to a depth of $40 \mathrm{~cm}$. The shaft was $280 \mathrm{~cm}$ long, and $265 \mathrm{~cm}$ long at the bottom. The width was $98-100 \mathrm{~cm}$ in the south, and $100 \mathrm{~cm}$ in the north.

\section{Description:}

The skeleton of a man lay in the grave extended on the back with the skull to S-SE, and the face turned to east. The right arm was extended along the body, the left hand rested on the thigh bone. Anthropological determination: male, $30-40$ years old. ${ }^{29}$

\section{Articles of wear:}

1. (3) A bronze bracelet on the bones of the left lower arm. It has open, seal-shaped, touching terminals. Textile remains could be observed at several parts on the bracelet. It is solid with an oval cross-section. Diam. $=$ $6 \times 7 \mathrm{~cm}$. (Fig. 13.7)

2. (4) An iron fibula on the right clavicle. It is a one-piece fibula twisted from a wire of round cross-section, fragmentary. Length $=6.5 \mathrm{~cm}$. (Fig. 13.2)

3. (6) Bronze fibula (Marzabotto type) between the right elbow and the hilt of the sword. It is a one-piece fibula twisted from a wire of the oval section. The spring is large, the end of the foot is returned to the bow and is four times beaded in disproportionate segments. Length $=8.5 \mathrm{~cm}$. (Fig. 13.1)

\section{Weapons:}

1. (7) Iron rivets beside the sword on the right hipbone. The diameter of the heads is $1.8 \mathrm{~cm}$. Fragmentary.

2. (8-9) An iron shield rim $10 \mathrm{~cm}$ outside the right leg. It is semicircular in cross-section and fragmentary. It could be observed only at the foot. (Fig. 13.9a-9b)

\footnotetext{
${ }^{28}$ It was originally above the ashes but a worker lifted it $\quad{ }^{29}$ Determination of K. Köhler.
} 
3. (10) An iron sword between the right arm and the body, between the elbow and the knee. Wood remains were observed on the hilt and the scabbard. Total length: $62 \mathrm{~cm}$, length of the hilt: $11.6 \mathrm{~cm}$. There is a pommel on the hilt and a rivet on the cross-bar standing perpendicular to the blade, ending in hemispherical heads on both sides. This fastened the grip covering the hilt iron. The diameter of the grip cover can be estimated from their measurements to have been $2 \mathrm{~cm}$. The blade is midribbed. The arched scabbard closed at the top bears the traces of two rivets on one side (Fig. 13.8a), and the traces of two more rivets could be observed on the cordiform chape (Fig. 13.8b). On the other side, there is a vertically placed suspension mount made for a $2.2 \mathrm{~cm}$ wide leather strap. Facing the suspension mount, large remains of coarse textile adhered to the scabbard, while the rust preserved plant remains at the chape. The width of the blade is $4.4 \mathrm{~cm}$. The total length of the scabbard: $58 \mathrm{~cm}$. Width of the scabbard at the hilt: $5.3 \mathrm{~cm}$. (Fig. 13.8c)

4. (5) A spear at the skull above the right shoulder pointing toward the shorter southern wall of the grave. The total length is $24 \mathrm{~cm}$, the length of the socket is $5.5 \mathrm{~cm}$, its diameter is $1.8 \mathrm{~cm}$. (Fig. 13.3)

5. An iron ring, a suspension element of the sword, round in cross-section, fragmentary. Diam. $=\mathrm{ca} .4 \mathrm{~cm}$. (Fig. 13.5)

6. A small, closed, flat iron ring rusted to the scabbard of the sword. Diam. $=2.5 \mathrm{~cm}$. Thickness $=0.3 \mathrm{~cm}$.

7. Two closed, flat iron discs perforated in the center. Diam. $=4-4 \mathrm{~cm}$. (Fig. 13.4)

Grave furniture:

1. (1) An urn tilted to the side between the left foot and the shorter wall of the grave with the mouth towards the bowl. The rim is everted, there is a rib in the arch of the neck, the shoulder, and the belly are separated by a groove. M.d. $=14 \mathrm{~cm}$, B.d. $=9 \mathrm{~cm}$, H. $=25 \mathrm{~cm}$. (Fig. 13.10 and Fig. 30.2)

2. (2) A large bowl beside the urn close to the right foot. The rim is everted, the neck is segmented by a rib in the arch, the bottom is omphalos-shaped. M.d. $=24 \mathrm{~cm}$, B.d. $=5 \mathrm{~cm}, \mathrm{H} .=8 \mathrm{~cm}$. (Fig. 13.11 and Fig. 33.2)

3. A pig jaw at the foot between the vessels and the shorter wall of the grave.

\section{Grave no 360}

Grave ditch: feature 302

Bone splinters ${ }^{30}$ were found in a heap in one-third of the northern stretch of the ditch in the upper $3 \mathrm{~cm}$ of the filling. Two discolourations could be discerned within the ditch. The ditch was parallel only to the larger one. Only the NE and the NW sides could be seen in an L-shape on the scraped surface. The ditch became shallow on the NW side, its continuation was not outlined. The SE part extended under the wall of the cutting. The width of the ditch was irregular, the cross-section was approximately U-shaped. Its greatest depth was $20 \mathrm{~cm} .{ }^{31}$ The grave ditch was $5.75 \mathrm{~m}$ long outside and $5.45 \mathrm{~m}$ inside on the eastern side, its width measured $50 \mathrm{~cm}$. On the northern side its length was $7.5 \mathrm{~m}$ outside and 6.9 inside in a width of $40 \mathrm{~cm}$. The western stretch was destroyed at the digging of ditch no. 306.

Shape and measurements of the grave: could not be determined.

Orientation: could not be determined.

Description: The feature was situated at the southern edge of the territory, partly under the humus deposition. Two discolourations (360.I and 360.II) appeared at the scraping of the surface. The larger one (360.I) had an NW-SE orientation, it measured $2.40 \times 1.20 \mathrm{~m}$. It was oblong-shaped with rounded corners filled in with strongly mixed, loessy humus. The scraping revealed slight iron oxide traces. There was no find in the shallow, only $3-5 \mathrm{~cm}$ deep mixed soil. The smaller discolouration (360.II) was perpendicular to the former one. It measured $0.9 \times 0.4 \mathrm{~m}$. Its shape was oblong with rounded corners showing iron oxide traces on the scraped surface. It did not resemble a grave. It had a NE-SW orientation. Its length was $92 \mathrm{~cm}$, width $41 \mathrm{~cm}$ and ended in a depth of $6 \mathrm{~cm}$. In the SW part, parallelly to the longer wall, two iron objects were found in the depth of $2 \mathrm{~cm}$, partly as a rust mark.

Finds:

1. Iron knife. Not even the core of the iron survived, only a strong rusty mark outlined its shape. ${ }^{32}$ (Fig.14.6c)

\footnotetext{
${ }^{30}$ They are unsuitable for anthropological determination.

${ }^{31}$ In the spirit of the contract with the Autópálya Igazgatóság (Highway Directorate) excavations could be conducted only within the track. Accordingly, the cuttings could only exceptionally be
}

enlarged. Here, it could not be done because of the service road beside the deposition.

${ }^{32}$ The objects are described after the excavation drawings in original size. Although it was lifted together with the embedding earth, the remains could not be conserved. 
2. The fragments of an iron object (perhaps scissors?) were found beside it. The laminar object seems to be returned from the point, the two edges are thick. (Fig.14.6.a-b)

3. A Münsingen-type bronze fibula was found by a metal detector in the seemingly unbroken yellow ground in the depth of 12-20 cm, about $30 \mathrm{~cm}$ north of the axis of the ditch. On the foot returned on the bow, there is a small disc decorated with a circle of punched dots in the centre. Dense transversal lines cover the bow. (Fig.14.5)

We started from the supposition that the grave ditch was shallower than the grave and the objects got to the level of their appearance in consequence of a later burial or a violation. So after having scanned the area with a metal detector, a pit was opened in the territory of the supposed grave within the grave ditch to a depth of $180 \mathrm{~cm}$ yet no trace of a grave could be observed. The cross-section of the control pit showed a lack of disturbance. It also revealed that similar to the sandy Szeles surface, patches of iron oxide discolourations appeared in the loessy sand, which is natural iron precipitation in the sand.

Surface remains suggest that the dead were only placed on the surface of the ditch, or were placed in a very shallow pit dug into the destroyed humus layer and then carried over to the top of the grave. The fences were deeper at this burial (!) than the grave itself.

Grave no. 361

Without grave ditch

Shape and measurements of the grave: The longitudinal axis of the grave has an S-SW-N-NE orientation. It was $170 \mathrm{~cm}$ wide in the middle. The depth of the grave shaft was $48 \mathrm{~cm}$ from the scraped surface.

Orientation: $\mathrm{N}+226^{\circ}$

Description: The grave appeared with an oval shape in the yellow alluvial sand. The skeleton of an adult lay in the grave on the back in an extended position. The right hand rested on the right hipbone, the left hand under

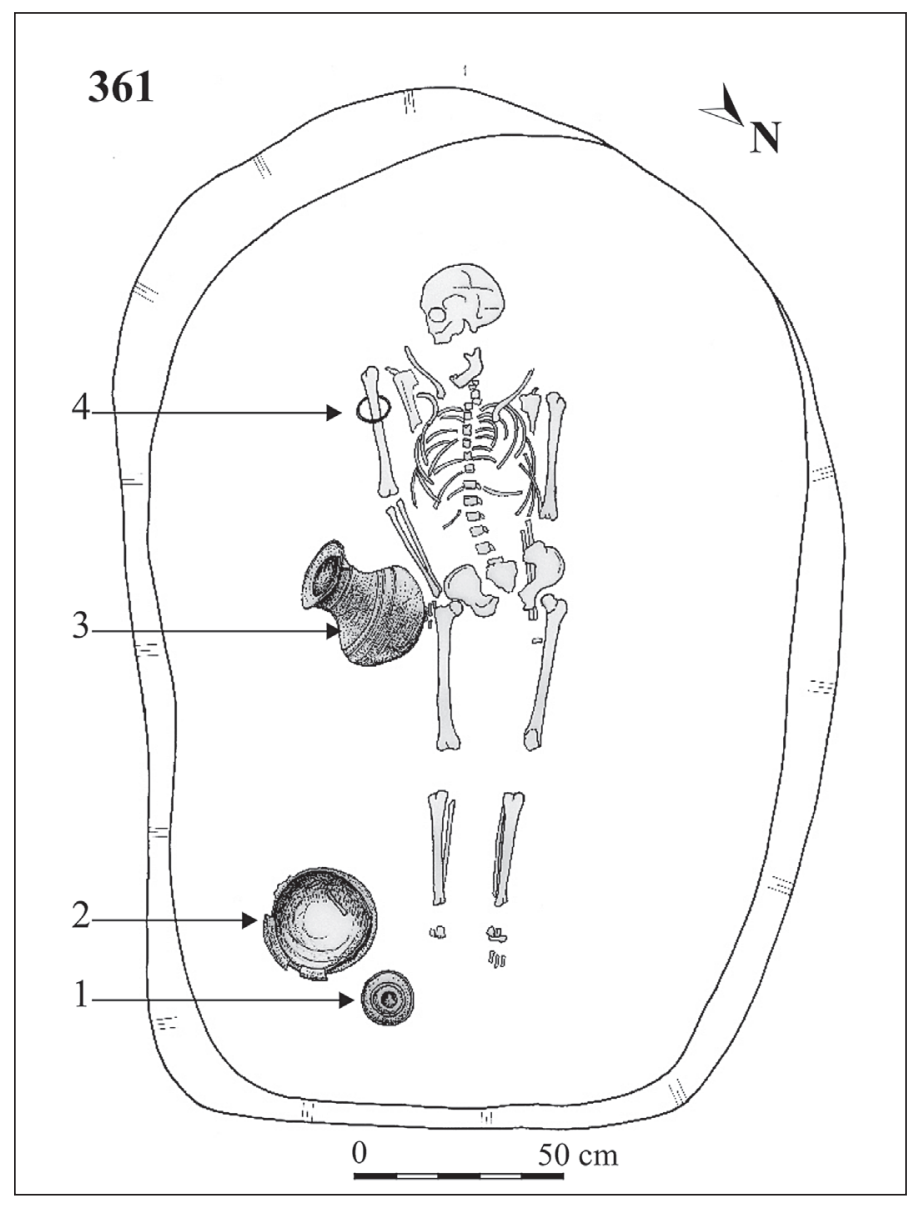

Acta Archaeologica Academiae Scientiarum Hungaricae 71, 2020 
the left hipbone. The face was turned to the right, to N-NW. The bones were relatively poorly preserved. Anthropological determination: male(?), 40-59 years old. ${ }^{33}$

\section{Article of wear:}

1. (4) A closed, solid, cast, undecorated, smooth bronze bracelet of round cross-section was found on the right upper arm. Diam. $=9 \mathrm{~cm}$. (Fig.14.1)

\section{Grave furniture:}

1. (3) An urn tilted on the side was found outside the upper part of the right thighbone. It seems to have been tilted by the weight of the earth and, at the same time, it got shifted towards the right hand and the pelvis of the deceased during the burial. The urn has an everted rim and two parallel ribs in the arch of the neck. The shoulder is separated from the belly by a groove and two further grooves run round the belly. M.d. $=16 \mathrm{~cm}$, B.d. $=10 \mathrm{~cm}$, H. $=31 \mathrm{~cm}$. (Fig.14.2 and Fig. 30.4)

2. (2) A large bowl stood between the right ankle and the longitudinal wall of the grave. It was already fragmentary when placed in the grave. The bottom is very weathered. It is black, the clay was tempered with sand. In section it is lighter grey in the middle. There is a rib in the arch of the neck bordered by a groove below it and another groove runs round the shoulder. M.d. $=25 \mathrm{~cm}$. (Fig.14.3)

3. A small - Beled-type - bow $\boldsymbol{l}$ beside grave furniture no. 2 and the right foot. There is a double groove on the omphalos-shaped bottom. The surface is horizontally smoothed in the upper part and coarsened in the lower one. The colour of the wheel-thrown vessel is greyish brown, the clay was tempered with sand. M.d. $=11 \mathrm{~cm}$, B.d. $=6 \mathrm{~cm}, \mathrm{H} .=3 \mathrm{~cm}$. (Fig.14.4)

\section{Grave no. 362}

\section{Without grave ditch}

Shape and measurement of the grave: The irregular, narrow grave shaft had an S-SE-N-NW orientation. Its width was $90 \mathrm{~cm}$, its length $225 \mathrm{~cm}$. Its depth $26 \mathrm{~cm}$. The grainy sand filling of the shaft was lighter than the environment. The grave was excavated to a depth of $200 \mathrm{~cm}$ because of the depth of the grave and the sandy soil,

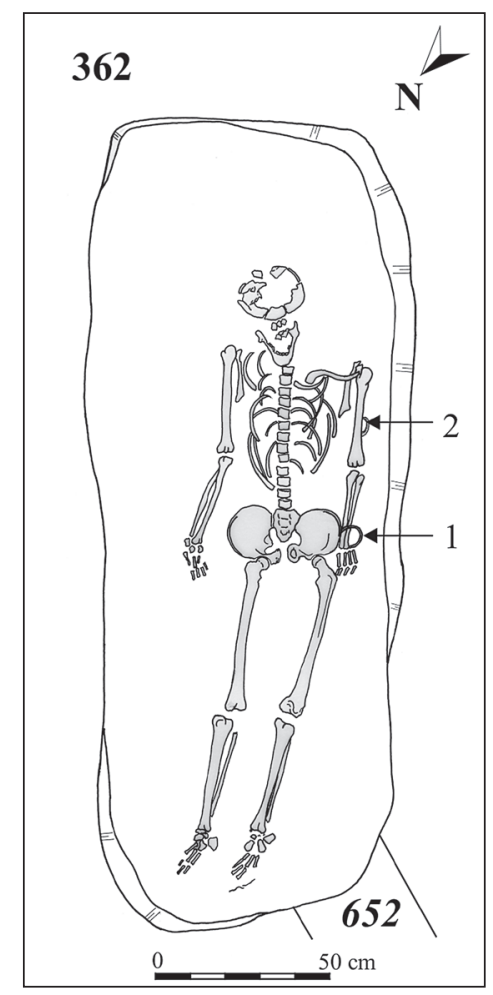

${ }^{33}$ Determination of K. Köhler. 
although the hardness of the filling of the shaft could be differentiated from that of the bottom. In greater depths, the ground proved to be unbroken

The grave intersected ditch no. 652 .

Orientation: $\mathrm{N}+242^{\circ}$

Description: The skeleton lay in the grave on the back with the skull to S-SE. The legs were bent in an arch toward the northern corner of the grave. The arms were extended only the right arm was slightly bent at the elbow. The skeleton was medium well preserved, its measurable length was $167 \mathrm{~cm}$. The age and sex are indeterminable. ${ }^{34}$

\section{Articles of wear:}

1. A bronze bracelet of oval cross-section with open terminals was found on the left lower arm. The open terminals are ridged. Very thin bronze wire is densely coiled on one of the open terminals in a length of $1.9 \mathrm{~cm}$. (Fig. 11.16)

2. The fragment of a Dux-type iron fibula was found under the left upper arm. The bow is of round crosssection, the foot is returned on the bow, its end is divided into three segments. A part of the catch plate, the head and the pin is missing. Only a small part of the pin survived. (Fig. 11.15)

Grave no. 364 (Fig. 16)

\section{Grave ditch: feature no. 365}

It is wider and shallower than the other grave ditches. Its average width was between $50-30 \mathrm{~cm}$, its depth measured $8-10 \mathrm{~cm}$. It is semicircular is cross-section. There was an oval depression in the northern stretch, which was of the same depth as the ditch. Its uniform filling, which did not contain finds, was also identical with that of the grave ditch. It is contemporary to the grave ditch. The ditch was later disturbed by several features, still it seems that it did not have a regular quadrangular course. The northern and the eastern ditches were arched, the southern one was straight. The arch of the eastern section, nevertheless, does not imply a regular circular shape for the grave ditch. The length of the eastern ditch stretch was $6.2 \mathrm{~m}$ outside and $5.9 \mathrm{~m}$ inside, its width was $50 \mathrm{~cm}$. The northern one measured $5 \mathrm{~m}$ outside and $4.8 \mathrm{~m}$ inside in a width of $50 \mathrm{~cm}$.

Roman ditch no. 299 intersected it to a depth of $86 \mathrm{~cm}$ and disturbed the grave as well.

Shape and measurements of the grave: cannot exactly be determined, except for the length of the axis, which was $270 \mathrm{~cm}$. The estimated depth of the grave was $58 \mathrm{~cm}$.

Orientation: $\mathrm{N}+232^{\circ}$

Description: It appeared as an oval, light brownish discolouration, which was intersected by a Roman ditch with darker filling. Celtic sherds were found already on the surface during scraping, which suggested disturbance. The filling of the grave was light, somewhat brownish loessy. The outlines were vague. It was not only the ditch that damaged the grave, the looser sandy loessy soil fell in and was washed in at several places, first of all at the longer sides of the grave. Its length was $164 \mathrm{~cm}$, its width $100 \mathrm{~cm}$ at the vague outlines during scraping. 10-12 cm deeper, the shape of the shaft with the fallen insides was rectangular with rounded corners. Its width was about $90 \mathrm{~cm}$ in the south and $110 \mathrm{~cm}$ in the north in a depth of $58 \mathrm{~cm}$.

Ditch no. 299 that intersected the grave passed in the southern third of the shaft. Its bottom was deeper than that of the grave. The ditch was $86-87 \mathrm{~cm}$ wide in the middle with slanting walls. Based only the relatively less disturbed bones of the legs, the skeleton had a $\mathrm{S}-\mathrm{N}$ orientation with the skull to the south. Some of the bones were washed down on the southern wall of the ditch. Anthropological determination: Female, 20-x years old. ${ }^{35}$

\section{Article of wear:}

There wasn't any, or nothing survived.

1. Fragment of an iron object of oval cross-section from the filling of the grave. (Fig. 14.7)

\section{Grave furniture:}

1. An urn was broken to pieces in the southern corner of the shaft in the depth of $55 \mathrm{~cm}$. Some sherds were found in the filling where the ditch intersected the grave, a rim fragment lay at the northern wall of the grave. The rim is everted, there are two ribs on the neck and two grooves on the shoulder. M.d. $=16 \mathrm{~cm}$, B.d. $=10 \mathrm{~cm}$, H. $=28 \mathrm{~cm}$. (Fig. 14.8 and Fig. 30.5)

${ }^{34}$ Determination of K. Köhler.

Acta Archaeologica Academiae Scientiarum Hungaricae 71, 2020
${ }^{35}$ Determination of K. Köhler. 


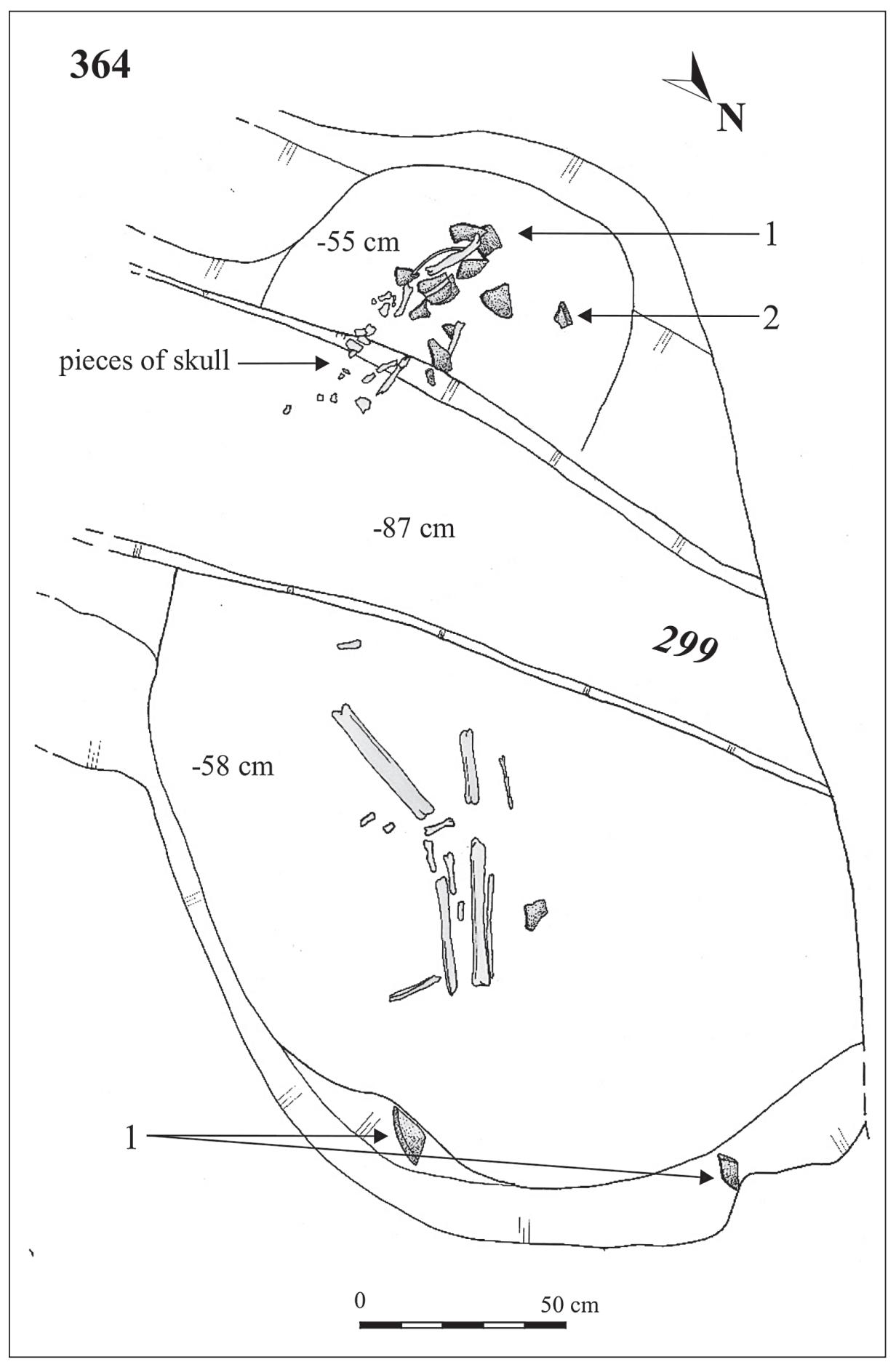

Acta Archaeologica Academiae Scientiarum Hungaricae 71, 2020 
Grave no. 367 (Fig. 17)

Without grave ditch

Appearance: at ditch no. 368/378 + 746. It intersects the ditch.

Shape and measurements of the grave: It was an elongated, oval discolouration with $250 \mathrm{~cm}$ and $117 \mathrm{~cm}$ long axes. Direction: NW-SE. The grave was filled in with a light mixed soil. The length of the axis was $230 \mathrm{~cm}$ on the scraped surface. The grave had a regular oblong shape at the bottom, where its length was $210 \mathrm{~cm}$. The width of the grave was $115 \mathrm{~cm}$. The depth of the grave was $78 \mathrm{~cm}$ from the scraped surface.

Orientation: $\mathrm{N}+228^{\circ}$

Description: The longitudinal axis of the grave shaft had a N-NW-S-SE orientation. The short southeastern wall of the grave ended in a semicircle on the surface. The length of the poorly preserved female skeleton was $144 \mathrm{~cm}$. It lay extended on the back. The bones of the right foot and partly those of the left leg were displaced by an animal. Under and beside the skeleton, a plank (?) appeared as a brownish discolouration.

Anthropological determination: sex is uncertain. $40-x$ years old. ${ }^{36}$ The grave-goods suggest a woman.

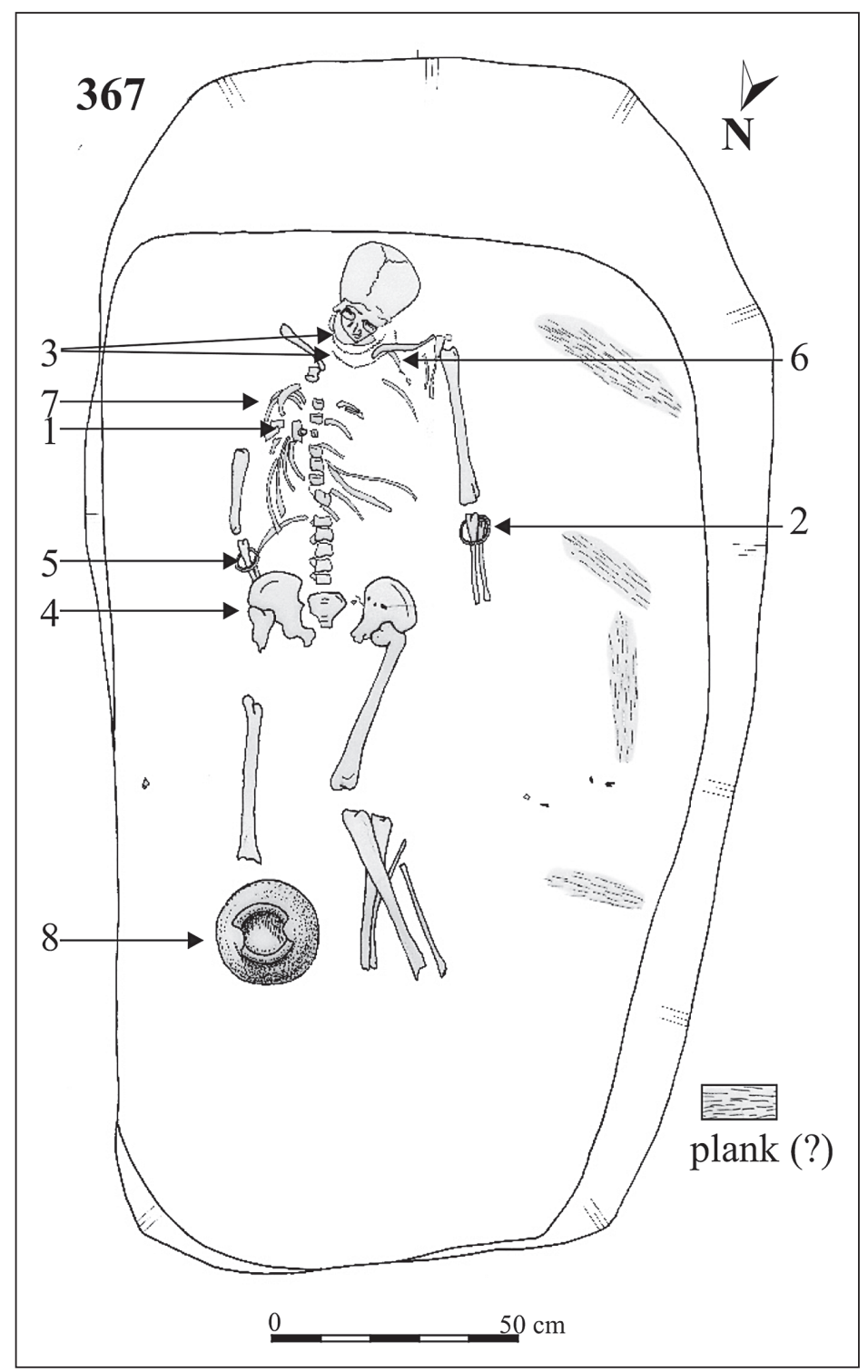

${ }^{36}$ Determination of K. Köhler. 
Articles of wear:

1. (3) A bronze torque at the cervical vertebrae. It was made of a twisted wire of round cross-section with hooked terminals. (Fig. 15.1a)

2. (3) Another bronze torque, similar to the former one, around the cervical vertebras. (Fig. 15.1b)

3. (1) A so-called bird head bronze fibula on the right side of the chest. The wide head plate is ornamented, the cord is internal, the bow widens similarly to the returned part of the foot. Both bear double incised lozenge ornaments. (so-called Doppelpaukenfibel) Length: $5.7 \mathrm{~cm}$. Fig. 15.2)

4. (1) A bronze pendant beside fibula no. 3. It consists of 5 thin trapezoid bronze plates with punched ornaments on the edges and a punched row in the middle. Below it there is a row of dot-and-circle patterns followed by two horizontally arranged dot circles. The plates were perforated at the top and threaded on an iron ring. Only the butt of the iron ring survived. ${ }^{37}$ (Fig. 15.3)

5. (7) Another fragment of an iron fibula on the chest (Dux-type?). The fragmentary fibula with the chord external conserved textile remains. Length: $9 \mathrm{~cm}$. (Fig. 15.4)

6. (6) The fragment of an iron fibula on the left clavicle. (Fig. 15.9)

7. (2) A bronze bracelet on the left lower arm, under the elbow. The bangle is oval in cross-section, cast, and solid. Diam: $7.3 \mathrm{~cm} \times 6.5 \mathrm{~cm}$. Textile remains were found at several spots on the surface (Fig. 15.5)

8. (5) A bronze bracelet on the right lower arm also at the elbow. It is similar to the above one except for the cross-section, which is semicircular. Diam: $6.7 \mathrm{~cm}$. (Fig. 15.6)

9. (4) The fragment of an iron clasp on the left hipbone. Fragments of the bent plate of an angular, hooked clasp with the remains of a rivet. (Fig. 15.7)

Grave furniture:

1. (8) An urn at the right foot. The rim is everted, there is a rib on the neck, the shoulder, and the belly are separated by a sharp carination. The bottom is omphalos-shaped. M.d. $=13 \mathrm{~cm}$, B.d. $=3 \mathrm{~cm}, \mathrm{H} .=15 \mathrm{~cm}$. (Fig. 15.10 and Fig. 31.6)

2. Several wall fragments of vessels were found in the filling of the grave. They were red outside and black, burnt inside, crumbling, impossible to reconstruct. Together with them lay a fragment of a small sandstone pipeform fulgurite. (Fig. 15.8)

Grave no. 375 (?)

Grave ditch: feature no. 374

The ditch intersected grave ditch no. 450. Its shape was different from that of the other ditches, it followed a round track. Its filling was uniform, the cross-section was semicircular. It was shallow with an average depth of about 8 to $15 \mathrm{~cm}$. It was interrupted in the southern section or it became so shallow that it gradually disappeared. The area enclosed by the round grave ditch was $14.11 \mathrm{~m}^{2}$.

Description: It appeared as a round, brownish-yellow discolouration with a diameter of 90-95 $\mathrm{cm}$ in the centre of the round ditch no. 374. The discolouration had vague outlines. It was divided into two sections and one half was first excavated. The discolouration gradually became fainter and ended in the depth of $20 \mathrm{~cm}$. It did not contain either animal bones or anthropological material or archaeological finds. Due to the character of the sandy soil, we deepened to a depth of $200 \mathrm{~cm}$ cutting though the discolouration but the unbroken ground did not change, it did not contain archaeological finds and traces of pits.

\section{Graves nos 376/A - 376/B \\ Without grave ditch}

Description: Grave no. 376 appeared deeper than the neighbouring grave no. 377 encircled by a grave ditch. It could not be spotted on the mechanically scraped surface, or even on the manually scraped surface although grave no. 377 could be observed there. Only some moist spots of vague outlines indicated that a disturbed soil, looser than the unbroken ground with different absorption qualities, can be found under the sand filling. On the second manually scraped surface, $5-7 \mathrm{~cm}$ deeper in the sandy soil, a very faint discolouration indicated the oblongshaped grave with somewhat irregular, rounded corners and spots caused by the one-time vegetation. At the place

\footnotetext{
${ }^{37}$ The remains of the iron ring perished during restoration.
} 


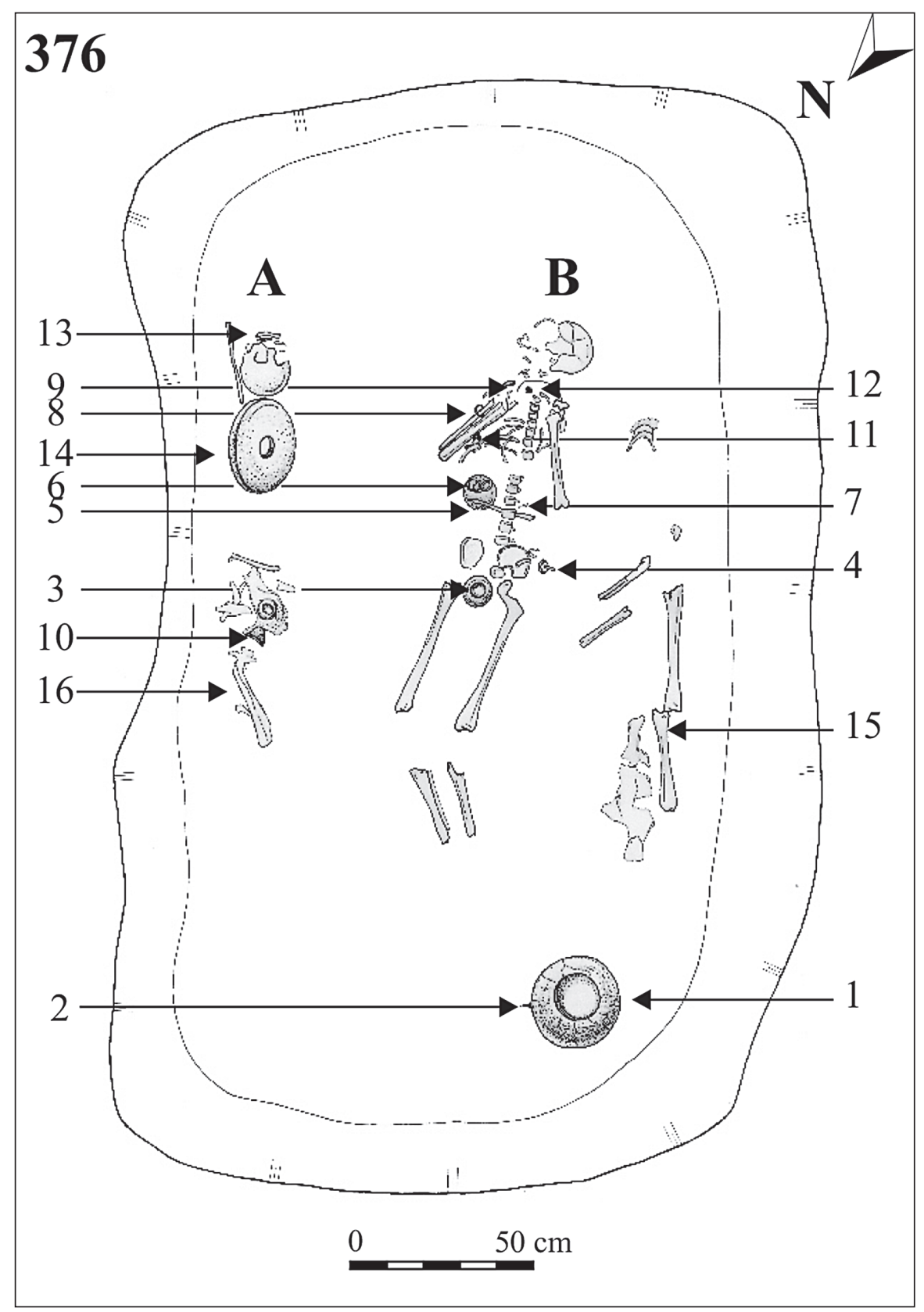

where the moisture of the soil showed the corners of the grave, the discolouration was $200 \mathrm{~m}$ long and $80-85 \mathrm{~cm}$ wide. The outlines of the real grave shaft appeared only $5-7 \mathrm{~cm}$ deeper from the scraped surface during excavation. Here the length of the shaft was $300 \mathrm{~cm}$, its width $192 \mathrm{~cm}$. The shaft all around narrowed downwards. The shaft of the second burial was dug along the same axis, and it was probably larger in every direction. The appearance of the grave shaft suggested that that the second burial no. 376/B and the underlying grave 376/A were older than the neighbouring grave no. 377 .

Shape and measurements of the grave: The grave shaft was oblong-shaped with rounded corners and irregular sides. The length at the bottom (first shaft) was $268 \mathrm{~cm}$, its width $150 \mathrm{~cm}$. Depth: $92 \mathrm{~cm}$. 
Orientation: $\mathrm{N}+228^{\circ}$

Burial no. 376/A

The skeleton was disturbed, it lay along the eastern longitudinal wall of the shaft. It seemed that the remains of the dead and the grave-goods were heaped up on the bottom of the grave in the depth of $78 \mathrm{~cm}$ just before the second burial. Only the skull and the fragments of the long bones were preserved from the skeleton. ${ }^{38}$

\section{Articles of wear:}

1. (13) An iron fibula was found beside the skull among the bones. (Fig. 16.1)

2. (10) The fragment of a thin bronze fibula (?) pin of round cross-section was found among the animal bones in the medial line of the grave on the eastern side. (Fig. 16.2)

\section{Grave furniture:}

1. A bowl with everted rim with a rib in the arch of the neck. The bottom has a double omphalos-shape. M.d. $=24 \mathrm{~cm}$, B.d. $=8 \mathrm{~cm}$, H. $=8 \mathrm{~cm}$. (Fig. 16.3 and Fig. 33.3) It stood next to the skull in a secondary position.

2. Animal bones beside the eastern wall of the shaft (a cattle shoulder blade could be determined).

\section{Burial no. 376/B}

The second burial seems to have followed the first one after a longer period. The skeleton lay extended on the back not in the axis of the grave but somewhat to the west. Its orientation was also different from that of the grave. The depth of the shaft was $84 \mathrm{~cm}$. The legs lay parallelly, somewhat drawn up at the knees (flexed position). The right arm was bent to the shoulder. Only the left upper arm stayed in the original position, a burrowing animal removed the ulna. The position of the radius suggests that the left arm was bent under the body at a right angle above the pelvis. The place of the bracelet implies the same position. The post-cranial bones were incomplete, the bones of the hand and the feet were missing together with some of the ribs. Anthropological determination: male(?), 40-59 years old. ${ }^{39}$

\section{Articles of wear:}

1. (4) An open bronze ring of oval cross-section and overlapping terminals on the left side of the pelvis. The left lower arm was missing, the ring must have been on the left hand. (Fig. 16.6)

2. (5) A bronze bracelet between the pelvis and the elbow of the bent right arm, at the end of the left lower arm, which was bent under the body. A closed, solid, cast bronze ring with textile remains on the surfaces. There is a cast knob on one side. Diam. $=8 \mathrm{~cm}$. (Fig. 16.10)

3. (6) Two adhered, cast, and closed bronze rings of oval cross-sections on the above bronze bracelet. Both preserved textile remains. Diam. $=3-3 \mathrm{~cm}$. (Fig. 16.11)

4. (6) An open, cast, distorted ring of round cross-section on the above rings. The exterior is ridged. It also preserved textile remains on the surfaces. (Fig. 16.12) (Fig. 16.15)

5. (2) A fragment of a bronze wire of round cross-section beside the urn at the northern corner of the grave.

6. (3) A brick-coloured clay ring, burnt at some places to a lighter reddish shade, was found between the two caput femoris. Diam. $=8 \mathrm{~cm}$. (Fig. 16.13)

7. (7) The fragment of a bronze wire of round cross-section between the left upper arm and the vertebral column. (Fig. 16.5)

8. (8) The fragment of a bronze bracelet at the wrist of the bent right arm. It is oval in cross-section with the imprint of densely woven textiles in the patination. (Fig. 16.9)

9. (9) A bronze torque of round cross-section round the neck. One terminal ends in a perforated disc, the other terminal is hooked. The remains of three types of textiles were preserved on the surface. (Fig. 16.4)

10. (11) A Dux-type bronze fibula with textile remains between the elbow of the bent right arm and the ribs. The foot of the one-piece fibula with the chord external is returned on the bow. It is beaded in six segments. The bow is of round cross-section and the two sides bear incised ornaments. (Fig. 16.7)

11. (12) A closed bronze ring of oval cross-section on the finger of the bent right arm. It preserved the remains of fine, densely woven textiles. (Fig. 16.8)

\footnotetext{
${ }^{38}$ The bones were destroyed.
}

\footnotetext{
${ }^{39}$ Determination of K. Köhler.

Acta Archaeologica Academiae Scientiarum Hungaricae 71, 2020
} 


\section{Grave furniture:}

1. (1) An urn in the north-western corner of the grave. The rim is everted, there is a rib in the middle of the neck, the shoulder is sharply divided from the belly by a groove. The bottom is slightly arched. M.d. $=15 \mathrm{~cm}$, B.d. $=12 \mathrm{~cm}, \mathrm{H} .=23 \mathrm{~cm}$. (Fig. 16.14 and Fig. 32.3 )

2. Cattle long bones between skeleton B and the western wall of the grave shaft.

\section{Grave no. 377}

Grave ditch: feature (?) no. $368=378$

It is a stretch of a ditch broken at a right angle. Only sections of the northern and the eastern stretches survived. A N-S directed oblong-shaped discolouration appeared in the northern part of the ditch, not in the middle of the section but closer to the north-eastern corner: this was feature no. 746. Feature no. 746 was intersected by grave no. 367. Neither the ditch nor feature 746 contained find material. The position of the features, namely that grave no. 367 intersected both grave ditch no. $368=378$ and feature 746 , suggests that grave 367 was later than the ditch section and grave no. 377 .

Orientation: $\mathrm{N}+228^{\circ}$

Description: The outlines of grave no. 377 were quite vague on the mechanically scraped surface, it was rather the moisture of the soil that indicated it in a length of $250 \mathrm{~cm}$ and a width of $110 \mathrm{~cm}$. On the manually scraped surface (5-10 cm under the mechanically scraped surface) it was $230 \mathrm{~cm}$ long and $80 \mathrm{~cm}$ wide. The filling was a light mixed soil, somewhat darker than the environment. A darker discolouration of irregular outlines appeared at the southern third of the eastern longitudinal wall of the grave of a regular shape and another similar one could be observed aligned with it behind the western longitudinal side of the grave. Both of them intersected the grave on the surface where they appeared, they are the traces of vegetation posterior to the burial. They could be documented at the depth of $42-47 \mathrm{~cm}$. In this depth both discolourations intersected the walls of the grave. Two similar irregular discolourations could be discerned in the northern third of the grave. These, nevertheless, were situated inside the grave. The clearing of the pits revealed that they contained a natural humus filling mixed with sand. Their depth was $18-22 \mathrm{~cm}$. In the undisturbed area, the wall of the grave shaft was sand to a depth of 44-46 cm, which was lighter than the filling of the discolourations and the grave shaft. In the depth of $52-56 \mathrm{~cm}$, the sand became darker and mixed with greyish earth. The disturbance could not be detected here, only the clear outlines of animal burrows of sandy filling could be observed. The bottom of the grave was reached in a depth of $67 \mathrm{~cm}$. Neither bone nor finds were found in it. We carried on deepening to a depth of $250 \mathrm{~cm}$ although the bottom of the grave was distinguishable. The ground was unbroken without disturbance or finds, the colour turned first into light grey which was gradually replaced by dark grey clay.

\section{Grave no. 379}

\section{Without grave ditch}

The outlines of the grave could not be discerned on the mechanically scraped surface, only an amorphous discolouration indicated it, which reminded of the corner of a house. The soil was greyish clayey around the discolouration. The outlines of the grave distinctly appeared only in the depth of $60 \mathrm{~cm}$.

\section{Orientation: $\mathrm{N}+232^{\circ}$}

Shape and measurements of the grave: The shaft was $101 \mathrm{~cm}$ deep from the mechanically scraped surface. The width of the grave in a W-NW direction was $176 \mathrm{~cm}$, in the opposite direction it measured $132 \mathrm{~cm}$. Its axis was $260 \mathrm{~cm}$ long. The eastern wall of the shaft bulged at an angle in a length of $135 \mathrm{~cm}$. A vessel (No. 2) stood in this niche $15 \mathrm{~cm}$ above the bottom of the grave. The depth of the grave was $45 \mathrm{~cm}$.

Description: The body lay on the back in an extended position in the north-eastern half of the shaft in an $80 \mathrm{~cm}$ wide stripe. The vertebral column was bent towards the wall of the grave, the skull was inclined on the right clavicle, the left shoulder was drawn up. The maxilla slid into the skull. The bones were very poorly preserved. Some or all of the bones of the left hand and the left foot were missing. The right thighbone turned out of the socket. Anthropological determination: male(?), 20-59 years old. ${ }^{40}$ The belt clasp implies a woman!

\footnotetext{
${ }^{40}$ Determination of K. Köhler.
} 


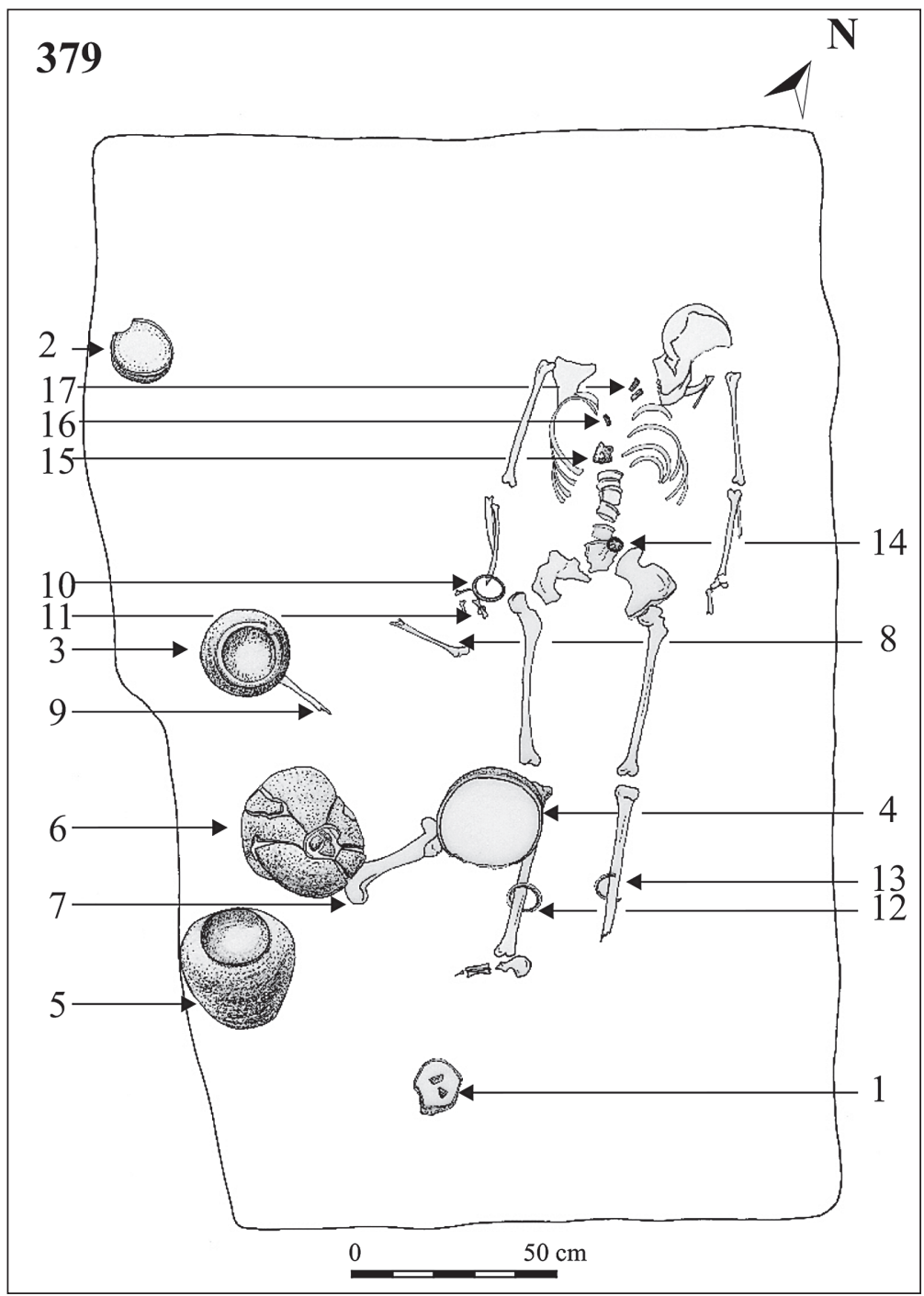

\section{Finds:}

1. (10) A bronze bracelet on the right wrist. The solid, open bracelet has seal-shaped terminals with two grooves. The body is all around ornamented by obliquely incised lines. Diam. $=6.5 \mathrm{~cm}$. (Fig. 17.6)

2. (11) A bronze finger ring on a finger of the right hand (cannot be told on which one). It is round in cross-section, solid and fragmentary. A sheet is bent over it in a section. Textile remains rusted onto the surface. (Fig. 17.4)

3. (12) An anklet above the right ankle. It is hollow, round in cross-section, sleeved. There are incised linear ornaments on the two edges of the closing section. The engraved linear pattern fills in each a horizontal triangular field on the two terminals. There are four punched dot circles on the tops of the triangles. Textile rusted onto the anklet. Diam. $=9 \mathrm{~cm}$. (Fig. 17.8)

4. (13) A damaged bronze anklet above the left ankle. It is hollow, hooked, the terminal is broken, textile rusted onto the body in broadband. One terminal is transversally perforated and iron rust marks beside the hole indicate the missing iron rivet. Diam. $=9 \mathrm{~cm}$. (Fig. 17.7)

5. (14) An iron clasp of a hooked-quadrangular plate on the left pelvis. W. $=4 \mathrm{~cm}$. It must have been attached to an approximately 2,6 cm broad leather strap. (Fig. 17.5) 
6. (15) An iron fibula on the right part of the chest. Fragmentary, the returned fragmentary foot is four times beaded. It is one-piece with the chord external. (Fig. 17.3)

7. (17) An iron fibula on the breast bone. It is fragmentary, oval in cross-section, only a section of the bow and the spring were preserved. (Fig. 17.1)

8. (16) A bronze fibula on the breast bone. It is small, one-piece, with the chord external, the catch plate is turned to the side, the beaded end of the foot is returned on the bow. Both the end of the foot and the bow are ornamented with incised lines. L. $=2.5 \mathrm{~cm}$. (Fig. 17.2)

Grave furniture: There were six vessels in the grave beside the articles of wear. All except one lay in the north-western part of the grave shaft.

1. (1) The fragment of a small vessel between the right foot and the shorter wall of the shaft. It is a brownish fragment tempered with sand, the mouth is missing. There are vertically incised double lines on the lower part. B.d. $=5 \mathrm{~cm}$. (Fig. 17.11)

2. (2) A small bowl in the north-western corner of the grave in a depth of $95 \mathrm{~cm}$. It is small, with a vertical rim and a pressed globular body. The bottom is omphalos-shaped. M.d. $=8.8 \mathrm{~cm}$, B.d. $=3 \mathrm{~cm}, \mathrm{H} .=5 \mathrm{~cm}$. (Fig. 17.9)

3. (3) An urn with the mouth down outside the right thighbone The rim is everted, a rib runs round the arch of the neck and another one on the shoulder. It has a foot disk. M.d. $=15.5 \mathrm{~cm}$, B.d. $=12 \mathrm{~cm}, \mathrm{H} .=22 \mathrm{~cm}$. (Fig. 17.12 and Fig. 32.4)

4. (4) A bowl with the mouth down on the right leg bones. It lay partly on the leg bones and partly on the animal bone (no. 7). The rim is everted, the bottom is slightly omphalos-shaped. M.d. $=24 \mathrm{~cm}$, B.d. $=3.4 \mathrm{~cm}$, H. $=9 \mathrm{~cm}$. (Fig. 17.13 and Fig. 33.4)

5. (5) An urn in the northern corner. The rim is everted, a wide grooved rib runs round under the rim and another groove in the arch of the neck. There are two parallel grooves at the joining of the shoulder and the neck. The bottom is cut. M.d. $=17 \mathrm{~cm}$, B.d. $=14 \mathrm{~cm}, \mathrm{H} .=29 \mathrm{~cm}$. (Fig. 17.14 and Fig. 32.6)

6. (6) A broken, so-called Linsenflasche between grave furniture nos. 3 and 5 at the wall of the shaft. It is matt, tempered with sand, the mouth slightly widens, the neck bulges. The bottom continues without break from the belly. M.d. $=8.3 \mathrm{~cm}$, B.d. $=$ unmeasurable, $\mathrm{H} .=27.6 \mathrm{~cm}$. The vessel cracked under the weight of the earth, the neck sank into the broken body of the vessel. (Fig. 17.10 and Fig. 32.1)

7. Cattle foot bone between the right patella of the skeleton and grave furniture no. 4 .

8. Pig bone at the right hand.

9. Animal bone (indeterminable) beside grave furniture no. 3 .

\section{Grave no. 464}

\section{Grave ditch (?) feature no. 450}

The narrow, irregular grave ditch breaks at an obtuse angle. The axis of the grave is not parallel to that of the ditch but no other feature can be considered within the ditch frame since grave no. 465 is too far from the ditch. Grave ditch no. 450 was disturbed by the round ditch no. 374. It partly cut off the northern and eastern sections of ditch no. 450. The section of the ditch where it turns to south-west and the southern section was damaged by later features as well. At the neighbouring features, it could be observed that the original floor surface was shallower in the southern part and some of the features were ploughed away. The preserved northern section of the ditch was $3.6 \mathrm{~m}$ long and $25 \mathrm{~cm}$ wide. The western section was $3.5 \mathrm{~m}$ long and $30 \mathrm{~cm}$ wide.

\section{Orientation: $\mathrm{N}+204^{\circ}$}

Shape and measurements of the grave: The length of the grave shaft with rounded corners was $180 \mathrm{~cm}$, its width was $110 \mathrm{~cm}$ and $100 \mathrm{~cm}$. Depth: $35 \mathrm{~cm}$.

Description: It appeared as a light brown discolouration against the greyish yellow, mixed sandy-clayey soil. The unbroken ground, a brownish, mixed sandy soil could be seen in the walls of the shaft to a depth of $10-11 \mathrm{~cm}$. Deeper down, the shaft was dug into yellow sand. The bottom of the grave shaft was reached in a depth of $35 \mathrm{~cm}$. Neither bones nor finds lay in the shaft. To be certain, the control shaft was deepened first to the depth of $80 \mathrm{~cm}$, but it was filled only with seemingly intact yellow sand. Then we dug on to a depth of $200 \mathrm{~cm}$ but the situation did not change. 


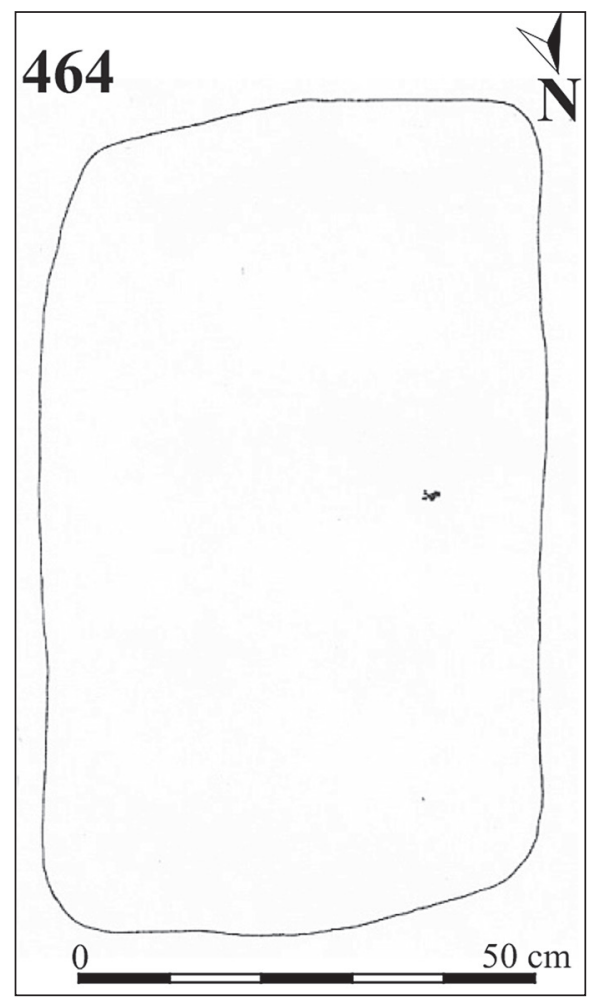

\section{Grave no. 465}

Without grave ditch

Orientation: $\mathrm{N}+228^{\circ}$ one is $150 \mathrm{~cm}$ long.

Shape and measurements of the grave: An oval shaft, the longitudinal axis is $200 \mathrm{~cm}$ long, the shorter

Description: It appeared as an oval patch with a sandy filling. Two small patches resembling animal burrows appeared in it. The sand fell in although it seemed intact, and a mixed layer appeared under it. The urn came to light in the north-eastern third right under the sand. A bench was found at the eastern, longitudinal wall in the depth of $58 \mathrm{~cm}$ but it stretched only to about half of the grave. It seemed as if the original wall of the grave were there. Total depth: $78 \mathrm{~cm}$. The skeleton was missing, only a few bone splinters remained at the western side: teeth and splinters of long bones. Feature 305 intersected the grave, which means that the grave was older than ditch no. 305. Anthropological determination: Infans I-II., 1-14 years old not cremated(!) child. ${ }^{41}$

\section{Articles of wear:}

1. (6) An iron fibula among the bone splinters. Textile remains could be found in the rust at several places. It is a one-piece fibula with the chord external, the end of the foot, and the pin broke off. (Fig. 18.1) (Fig. 18.2)

2. (6) A small, arched, flat iron plate fragment beside the iron fibula with wood remains in the rust.

3. (7-8) Iron fragments at the northern edge of the grave: the edge plates and mounts of a shield (?). Wood remains adhered to the iron. Judged from the arch of the edge plate, the wood could be $0.5 \mathrm{~cm}$ thick. (Fig. 18.3-6)

\section{Grave furniture:}

1. (3) A so-called Beled-type bowl with omphalos-shaped bottom encircled by a double foot ring was found in the centre. The rim is slightly everted, the wall was smoothed in two bands probably bordering a slight ridge in the arch of the neck. M.d. $=13 \mathrm{~cm}$, B.d. $=4 \mathrm{~cm}$, Height $=4 \mathrm{~cm}$. (Fig. 18.8)

\footnotetext{
${ }^{41}$ Determination of K. Köhler.
} 


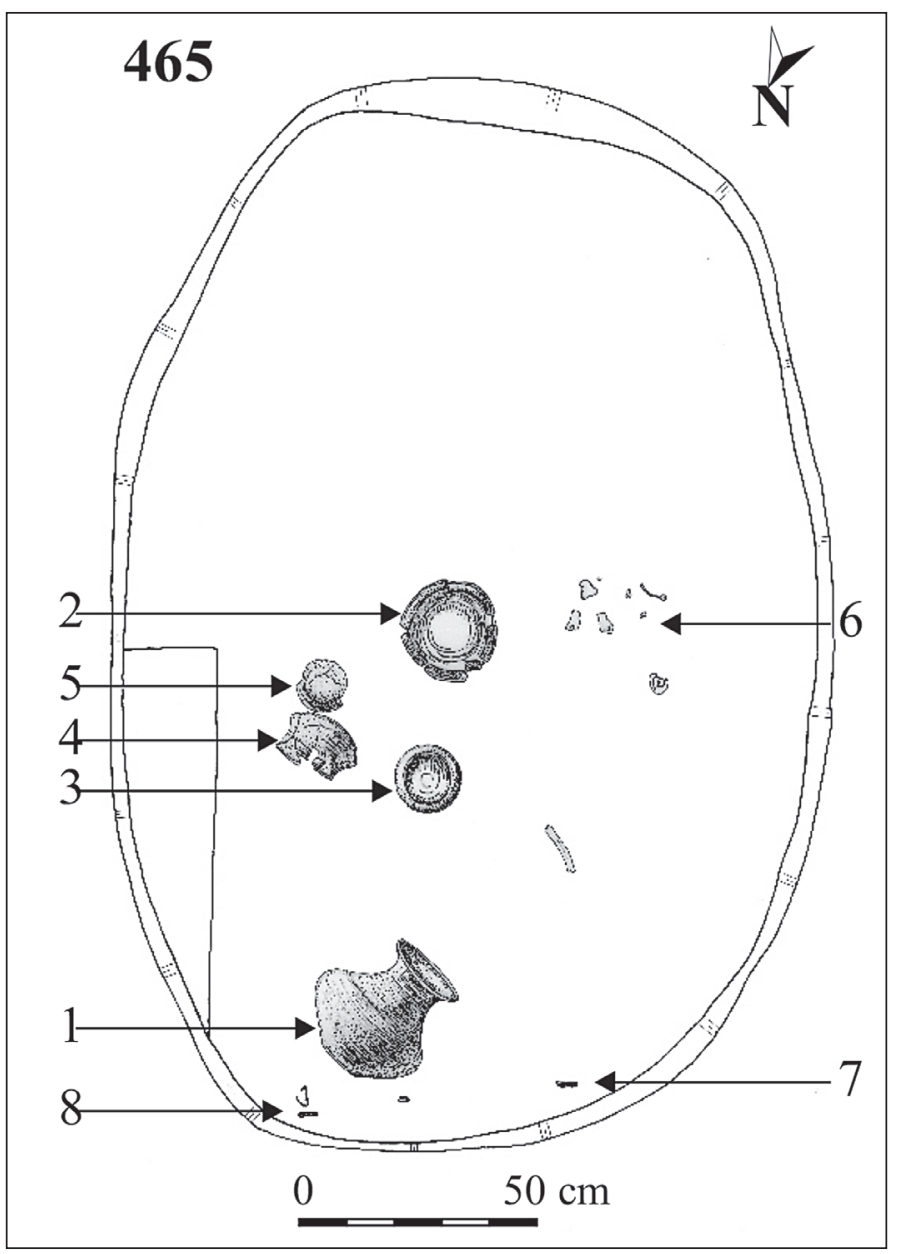

2. (1) A large urn in the northern end of the grave. The rim is everted, There are a groove and a rib on the neck, a wide groove on the shoulder and an even wider, shallower groove under it. M.d. $=16 \mathrm{~cm}$, B.d. $=10 \mathrm{~cm}$, H. $=25 \mathrm{~cm}$. (Fig. 18.9 and Fig. 30.1)

3. (2) A small bowl broken to pieces was found in the central part. M.d. $=18 \mathrm{~cm}$, B.d. $=2,5 \mathrm{~cm}, \mathrm{H} .=6 \mathrm{~cm}$. The rim is everted, there are two grooves on the neck. It is greyish brown, wheel-thrown, the clay is sandy. (Fig. 18.7)

4. (5) A small hand-made $\boldsymbol{b o w} \boldsymbol{l}$ beside the bench. It was adjusted on a wheel. It is brownish grey, tempered with sand. M.d. $=11 \mathrm{~cm}$, B.d. $=3 \mathrm{~cm}, \mathrm{H} .=5 \mathrm{~cm}$. (Fig. 18.10)

5. (4) Another vessel beside grave furniture no. 4. It is a small urn of everted rim, with a rib on the neck and a groove on the shoulder. It is wheel-thrown, brownish back, tempered with sand. M.d. $=12 \mathrm{~cm}$, B.d. $=6 \mathrm{~cm}$, H. $=12 \mathrm{~cm}$. (Fig. 15.10)

6. An animal bone fragment among the bones of the child. ${ }^{42}$

\section{Grave no. 737}

Without grave ditch

Orientation: $\mathrm{N}+212^{\circ}$

Shape and measurements of the grave: The grave did not appear either on the mechanically or on the manually scraped surfaces. Here the ground was a dark grey, clayey, loamy alluvial soil. We worked in a controlled cutting measuring $10 \times 10 \mathrm{~m}$. The slightly irregular, oblong-shaped grave shaft appeared in the depth of $58-60 \mathrm{~cm}$

${ }^{42}$ It cannot be determined more accurately. 
under the archaeologically intact soil. The width of the grave shaft was $120 \mathrm{~cm}$ in SE (at the skull) and $110 \mathrm{~cm}$ at the foot. (For fear the wall could fall in, the grave could not be opened in the whole width, since the earth scaled off in large lumps and fell into the shaft from every direction.) The relative depth from the mechanically scraped surface was $121 \mathrm{~cm}$.

Description: A very poorly preserved skeleton lay in a S-SE-N-NW direction in the grave. The measurable length of the skeleton was $160 \mathrm{~cm}$. The skull tilted from the original position, similarly to the jaw. The left arm and the left thighbone were in a secondary position as well. No animal burrow could be seen in the soil or the wall, but animal holes could not be observed anywhere in the greyish, clayey soil. The whole grave was underwater at the time of the excavation. The clearing of the grave proved difficult in the greyish black, smearing earth and the ceramics had to be removed with the earth packing. It could be seen both on the finds and the bones that they were

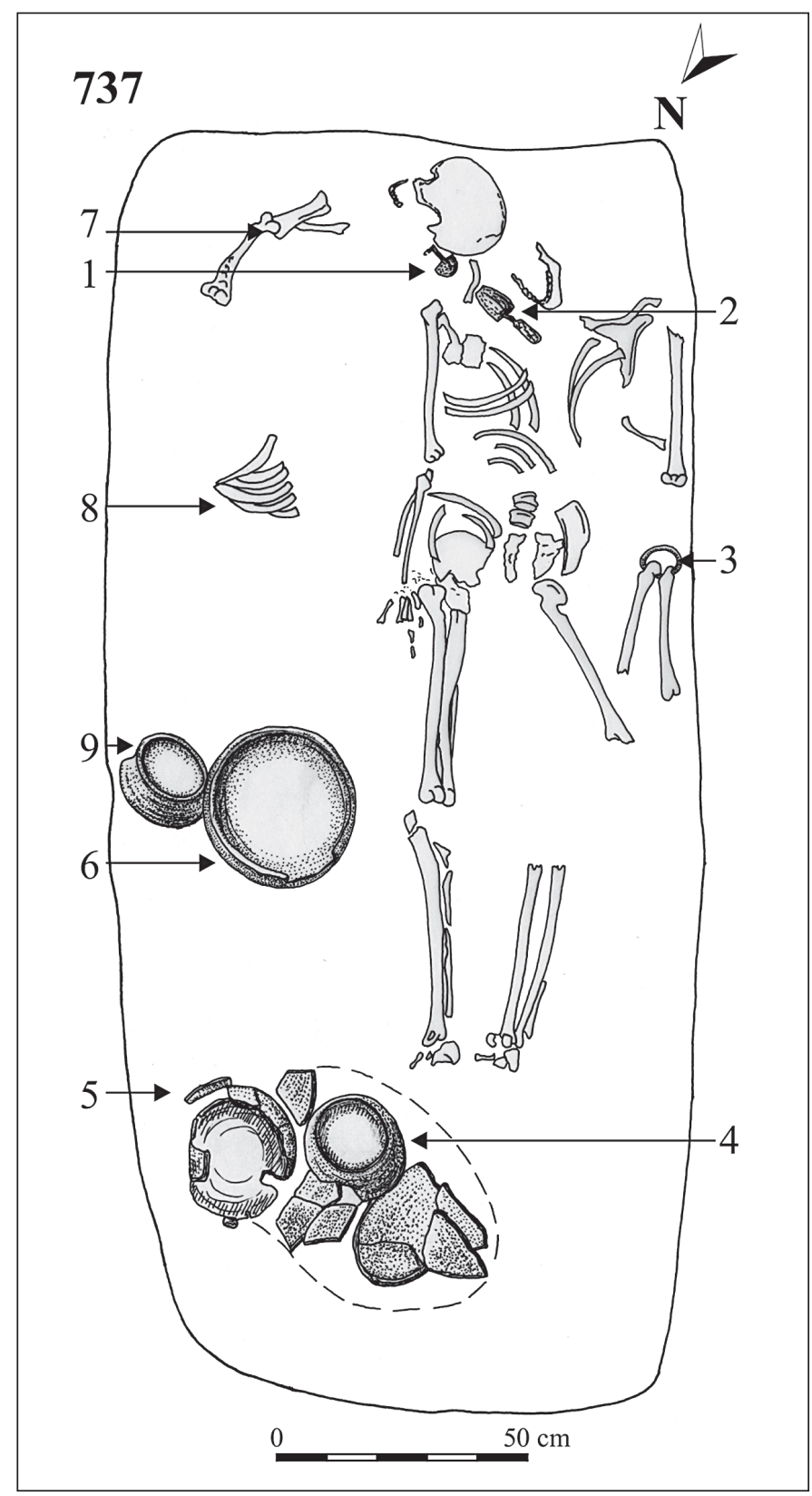

Acta Archaeologica Academiae Scientiarum Hungaricae 71, 2020 
strongly deteriorated by the frequently rising groundwater. The bones were brownish black, spongy and the pottery was soaked and pulpy. Anthropological determination: male, $40-50$ years old. ${ }^{43}$

\section{Articles of wear:}

1. (1) An iron fibula in the place of the right clavicle. It is fragmentary, a part of the bow together with the end of the foot is missing. It is a wide and large fibula with a spring gear and a large returned knob on the bow. It could be lifted only together with the earth. (Fig. 19.6)

2. (2) An iron fibula near the dislocated jaw, next to the left clavicle. It has a large spring of a large diameter. The bow bulges in the middle, the returned end of the foot ended in a large double globule. L. $=13.5 \mathrm{~cm}$. Similarly to the above item, it could be lifted only with the earth packing. (Fig. 19.5)

3. (3) A bronze bracelet on the left lower arm close to the elbow, where the animal burrow disturbed the grave. It is an open bracelet with slightly thickening terminals, cast, solid, oval in cross-section. Diam. $=7 \times 6.2 \mathrm{~cm}$. (Fig. 19.7)

\section{Grave furniture:}

1. (4) A broken vessel in the northern corner of the grave at the foot. The neck is steep, the clay was tempered with sand. The situla-shaped vessel has a shallow groove under the rim. A roulette ornament runs in a wavy line between two horizontal grooves on the carinated shoulder. M.d. $=10 \mathrm{~cm}$, B.d. $=11 \mathrm{~cm}, \mathrm{H} .=16 \mathrm{~cm}$. (Fig. 19.9 and Fig. 35.8)

2. (5) A broken urn at the wall in the northern corner of the grave. The rim is everted, a rib runs round the neck. There are two shallow grooves on the shoulder. Its colour is grey due to being baked in a reducing environment. At the top it is brick coloured, baked to a yellowish colour. The clay was tempered with sand. Originally it was grey on the outside. M.d. $=13.4 \mathrm{~cm}$, B.d. $=10.4 \mathrm{~cm}, \mathrm{H} .=26 \mathrm{~cm}$ (?). (Fig. 19.12)

3. (6) A large bowl between the right knee and the wall of the grave. It broke in the grave. On the inside there is a double roulette ornament in a wavy line, the waves leaning leftwards. It was baked in a reducing environment, its colour is brownish-black, lighter in cross-section. M.d. $=24 \mathrm{~cm}$, B.d. $=5 \mathrm{~cm}, \mathrm{H} .=9 \mathrm{~cm}$. (Fig. 19.11 and Fig. 34.3)

4. (9) A biconical bowl with everted rim leaning against the middle of the south-eastern wall of the grave beside the large bowl. It was secondarily burnt and became reddish grey in spots, the clay was finely levigated. M.d. $=14 \mathrm{~cm}$, B.d. $=5 \mathrm{~cm}, \mathrm{H} .=6.5 \mathrm{~cm}$. (Fig. 19.8 )

5. A broken urn beside vessels nos 4-5. The rim is everted, there are a rib on the neck and two grooves on the shoulder. It is light grey, the clay was tempered with sand. M.d. $=13 \mathrm{~cm}$, B.d. $=10.6 \mathrm{~cm}, \mathrm{H} .=24 \mathrm{~cm}$. (Fig. 19.10)

6. (7) Animal bones in the south-eastern corner of the grave shaft (sheep bones).

7. (8) Animal bones between the right elbow and the longer wall of the grave (cattle ribs).

\section{Grave ditch no. 738}

The ditch is semicircular in cross-section with a uniform filling. It reached under the southern humus deposition. It extended towards the centre of the surface. The section turning to the west could be seen, while the northern and western sections could not be observed on the scraped surface. It was 20-25 cm wide and $12 \mathrm{~cm}$ deep in the excavated $5.2 \mathrm{~m}$ long section. The filling was uniform, only slightly darker than the blackish-grey environment. It did not contain finds. The outlines of a grave could not be observed within the ditch nor did the metal detector indicate finds. To be certain, a control cutting was opened within the ditch but no pit could be found and there weren't any finds either. From the features of the Celtic cemetery only cremation burial no. 298 fell between the grave ditch and the black, deep part with moist filling in the blackish grey soil.

\section{Grave no. 744}

\section{Grave ditch: feature no. 745}

The grave ditch was intersected by grave ditch no. 306 and it destroyed the eastern and partly the northern sections of ditch no. 745. A small, round depression appeared in the western stretch, which intersected only the southern wall of the ditch. The western stretch of the grave ditch was $5 \mathrm{~m}$ long outside and $4.8 \mathrm{~m}$ inside, its width measured $35 \mathrm{~cm}$. The northern stretch was $4 \mathrm{~m}$ long and $30 \mathrm{~cm}$ wide.

\footnotetext{
${ }^{43}$ Determination of K. Köhler.
} 
Orientation: $\mathrm{N}+228^{\circ}$

Shape and measurement of the grave: An oblong-shaped shaft with a S-SE-N-NW directed axis. Its width at the south-eastern wall was $113 \mathrm{~cm}$, and $105 \mathrm{~cm}$ at the N-NE-S-SW wall. The length of the axis was $254 \mathrm{~cm}$, its depth $67 \mathrm{~cm}$.

Description: The soil was greyish, clayey, and mixed. Downwards it became more and more grey and moist, a smearing yet compact clay. The poorly preserved skeleton was disturbed by animal burrows. It lay on the back with slightly flexed legs toward NE. Intermittent groundwater deteriorated the bones and the metal finds. The skull tilted from its original position. It lay close to the southern wall, the mandible was displaced into the height of the right shoulder. Anthropological determination: male(?), 35-45 years old. ${ }^{44}$ The archaeological material implies a male!

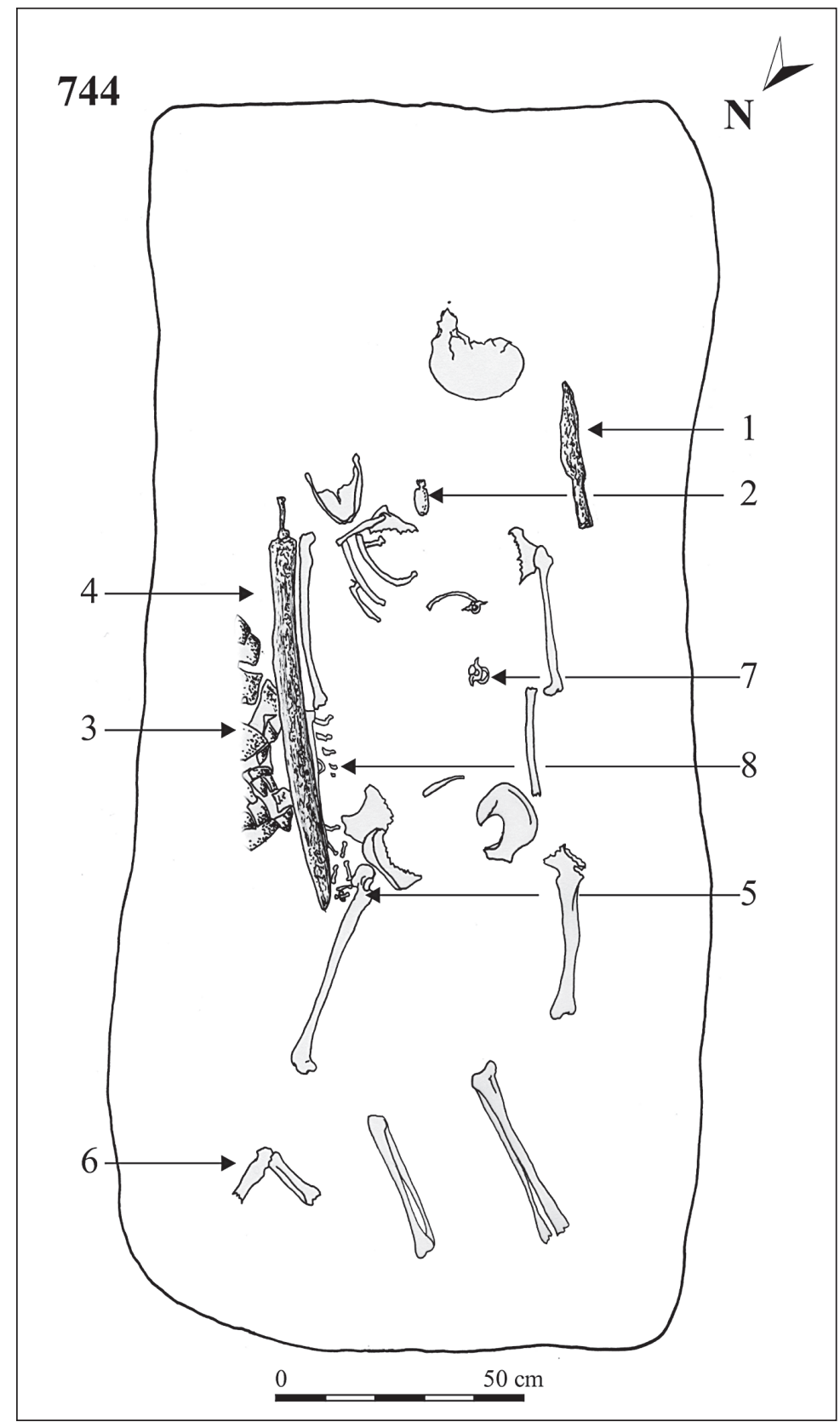

${ }^{44}$ Determination of K. Köhler. 


\section{Articles of wear:}

1. (1) A one-armed iron fibula at the right clavicle. H. $=6.5 \mathrm{~cm}$. (Fig. 20.2)

2. (7) An iron fibula above the right pelvis. It is solid, bent to the side, the catch-plate is small. It has broad spring arms, the chord is external. H. $=5.3 \mathrm{~cm}$. (Fig. 20.4)

3. (5) A silver finger-ring on the middle finger of the right hand. It is solid, cast, of round cross-section. Diam. $=2.3 \mathrm{~cm}$. (Fig. 20.3)

4. (8) Fragment of an iron ring under the sword (disintegrated).

\section{Weapons:}

1. (1) A spearhead beside the right upper arm, between the upper arm and the wall of the grave pointing toward the shorter wall at the head (which means it was probably put into the grave with the intact shaft). $\mathrm{H}$. $=25 \mathrm{~cm}$, Diam. $=2 \mathrm{~cm}$, length of the socket $=7 \mathrm{~cm}$. It is midribbed, the socket is oval in cross-section, and shows the places of two rivets. (Fig. 20.1)

2. (4) An iron sword between the right shoulder, and the thigh bone, beside the body, in the direction of the grave wall. It is double-edged, $82 \mathrm{~cm}$ long, the hilt is $11.5 \mathrm{~cm}$ long, ending in an antenna, which was preserved only on one side. The width of the remaining antenna was $2 \mathrm{~cm}$. The blade has a midrib, the width of the blade is $5.3 \mathrm{~cm}$ at the hilt. Under the antenna, a small fragment of the bone grip plate is preserved with the remains of an iron rivet. The thickness of the bone plate is $0.9 \mathrm{~cm}$. The scabbard with an arched termination was $5.6 \mathrm{~cm}$ wide at the top. The textile of coarse weaving was found at several parts of the scabbard. The length of the suspension mount, which ends in two semicircles, is $4 \mathrm{~cm}$, it was prepared for an approximately $2 \mathrm{~cm}$ wide leather strap. At the same place, two iron nails with hemispherical heads were also found. (Fig. 20.6a-c)

\section{Grave furniture:}

1. (3) A broken urn between the sword and the wall of the grave. There are two grooves on the shoulder and a horizontal S-motive arranged within an imprinted triangle under it. M.d. $=20 \mathrm{~cm}$, B.d. $=12 \mathrm{~cm}, \mathrm{H} .=24 \mathrm{~cm}$. (Fig. 20.5 and Fig. 32.5)

2. (6) Animal bone remains between the right leg and the wall if the grave. ${ }^{45}$

\section{Grave no. 752}

Without grave ditch

Orientation: $\mathrm{N}+240^{\circ}$

Its top was partly intersected by medieval ditch no. 382. The skeleton was not disturbed.

Description: The grave shaft was deepened into the grey, moist, paludal mud, and the bones were rather poorly preserved. The grave shaft was narrow, oblong-shaped, its relative depth from the mechanically scraped surface was 59-62 cm. The width of the grave shaft was $53 \mathrm{~cm}$, its length measured $161 \mathrm{~cm}$. Its axis had a S-SEN-NW direction. The skeleton lay with the skull to S-SE. It did not lie in the middle but the eastern half of the narrow grave. The skull-faced east, the left arm was bent at the elbow and placed across the chest. The right arm was extended along the body. The right leg was slightly bent at the knee. There is a mark of a blow on the left temple. Perhaps this must have caused the death. Measurable length of the skeleton in the grave: $151 \mathrm{~cm}$. Anthropological determination: female, $34-43$ years old. ${ }^{46}$

\section{Articles of wear:}

1. (1) A bronze fibula on the right clavicle. It is a one-piece fibula with the chord external, the foot returned on the bow was twice partitioned with beading. There is an engraved pattern on the bow: a ring within a lozenge. Length: $2.7 \mathrm{~cm}$. (Fig. 12.9)

2. (2) A bronze fibula on the left clavicle. The small one-piece fibula with the chord external had the foot returned on the bow. The foot is terminated in a hemisphere above triple beading. The bow is round in cross-section. Length: $3 \mathrm{~cm}$. (Fig. 12.8)

3. (3) A solid, closed iron ring, round in cross-section, beside the fibula on the left clavicle. Diam. $=3 \mathrm{~cm}$. (Fig. 12.10)

\footnotetext{
${ }^{45}$ They cannot be determined more accurately. $\quad{ }^{46}$ Determination of K. Köhler.
} 


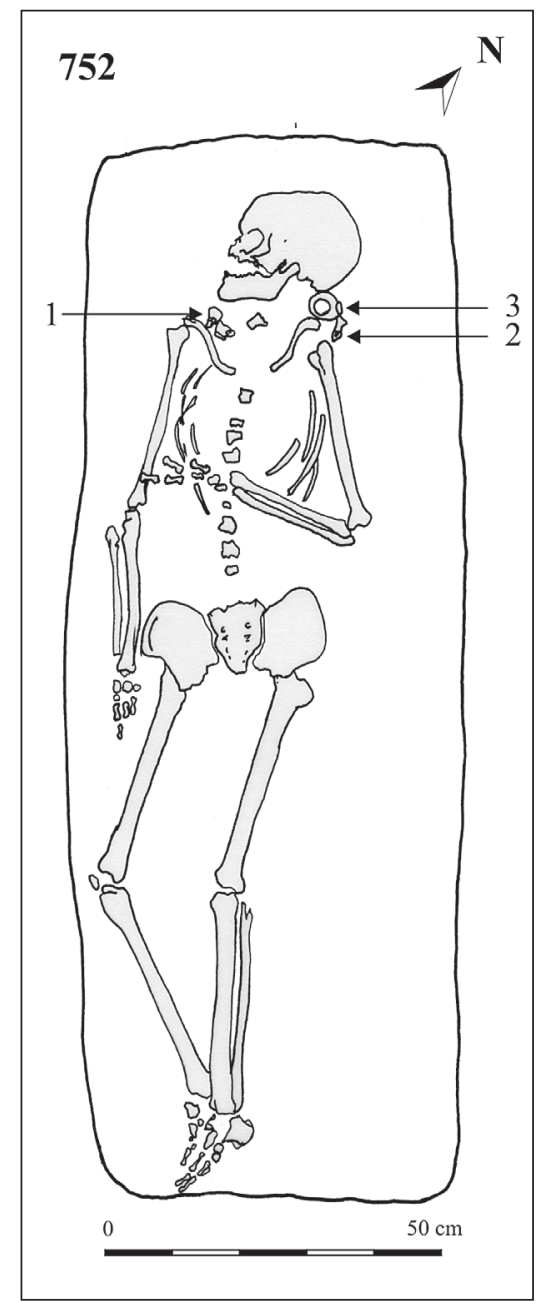

\section{Grave no. 754}

Without grave ditch

A surface of daub was unearthed above the grave (feature no. 386). The daub surface was burnt, red, with precipitated lime grains and traces of mortar around it. It appeared already on the scraped surface. The outlines were irregular measuring $90 \times 72 \mathrm{~cm}$, its depth was $20 \mathrm{~cm}$.

Orientation: $\mathrm{N}+234.5^{\circ}$

Description: It did not appear on the mechanically scraped surface since in this area nothing appeared in the black, clayey humus. Its faint outlines appeared $30 \mathrm{~cm}$ deeper in the control cutting. The oblong-shaped grave shaft was dug in the grey paludal clay. The axis of the grave had a S-SE-N-NW orientation. The width of the grave shaft was $70 \mathrm{~cm}$, and $80 \mathrm{~cm}$ at the feet. The length of the axis was $145 \mathrm{~cm}$. Its depth (from the mechanically scraped surface) was $70-78 \mathrm{~cm}$. The bones were rust coloured and crumbled in splinters. The length of the skeleton could not be measured. It could not be observed, either, how the skeleton lay. The axis length of the grave, which was strikingly short in the cemetery, and the measurements of the surviving post-cranial bones (an adult!) suggest a crouched position. The filling of the grave was mixed clayey, moist. The remaining bones were coloured to brown and disintegrated into splinters. Only the outline of the skull remained on the western edge of the grave.

The grey clayey unbroken ground taken out at the digging of the grave was refilled in large lumps. Bone remains unsuitable for anthropological determination.

\section{Articles of wear and use:}

1. (5) An iron $\boldsymbol{a} \boldsymbol{w} \boldsymbol{l}$ at the neck. It is round in cross-section, with a tapering end. L. $=7.6 \mathrm{~cm}$. (Fig. 19.3) 


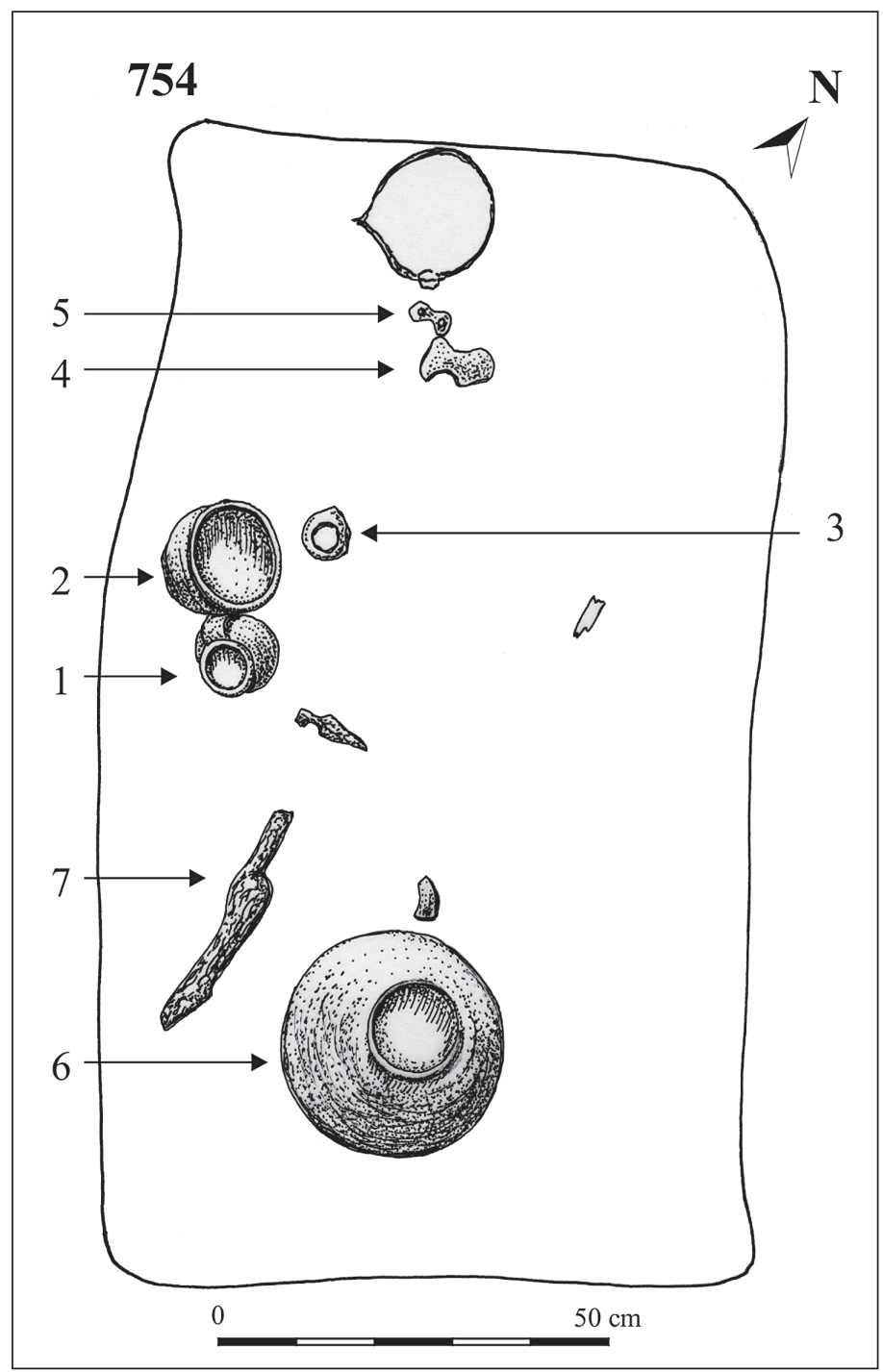

2. (4) An iron fibula at the neck. It has a wide arm with a large spring, the foot is returned at an angle on the bow and terminates in a globular element. (Fig. 19.1)

3. (3) An iron ring in the place of the right arm. It is closed, round in cross-section. Probably a closed-ended iron bracelet. Diam. $=5.5 \times 7.5 \mathrm{~cm}$. $($ Fig. 19.2)

4. (7) An iron knife in the place of the lower right leg. Single-edged, slightly arched back. A fragment of two rivets on the handle of the handle and a fragment of an angle indicates the attachment of the wood handle. (Fig. 19.4)

\section{Grave furniture:}

1. (6) A black bowl baked in a reducing environment. The rim is everted, the bottom is omphalos-shaped. M.d. $=25.8 \mathrm{~cm}$, B.d. $=5.8 \mathrm{~cm}$, H. $=9 \mathrm{~cm} .($ Fig. 18.15)

2. (3) Another broken bowl. It was baked in a reducing environment. M.d. = about $20 \mathrm{~cm}$. (Fig. 18.14)

3. (2) A bowl between the wall of the grave and the place of the right arm. M.d. $=11.5 \mathrm{~cm}$, B.d. $=4 \mathrm{~cm}$, H. $=5.5 \mathrm{~cm}$. (Fig. 18.12 and Fig. 35.2)

4. (1) A cup next to the previous bow. It is one-handled, burnt (?) to a black colour, the surface is coarse. The band handle is oblong-shaped in cross-section, it starts from the rim and joins the shoulder of the vessel above the biconical carination on the belly. M.d. $=7 \mathrm{~cm}$, B.d. $=5 \mathrm{~cm}$, H. $=7.6 \mathrm{~cm}$. (Fig. 18.13 and Fig. 34.1) 


\section{Grave no. 755}

\section{Grave ditch: feature no. 756}

The grave ditch was partly destroyed. The northern section reached under the humus deposition. The western stretch was $4 \mathrm{~m}$ long outside and $3.85 \mathrm{~m}$ long inside. The southern stretch was $5 \mathrm{~m}$ long outside and $4.8 \mathrm{~m}$ long inside, where it was $30 \mathrm{~cm}$ wide. The width of the ditch varied between 15 and $30 \mathrm{~cm}$, its depth was $20-22 \mathrm{~cm}$. It was semicircular in cross-section. It was filled with a slightly brownish, mixed sand. There were no finds in it.

Orientation: $\mathrm{N}+224^{\circ}$

Shape and measurements of the grave: The grave shaft was rounded, arched on the southern side, where its width was $121 \mathrm{~cm}$. On the northern side, it was $126 \mathrm{~cm}$ wide. The length of the grave was $230 \mathrm{~cm}$. A small pit could be observed at the feet, partly under the humus deposition, the bottom of which was somewhat deeper than that of the grave. Depth of the grave: its discolouration appeared $74 \mathrm{~cm}$ under the present ground level, the bottom of the grave was $115 \mathrm{~cm}$ from the mechanically scraped surface and $75 \mathrm{~cm}$ from the appearance.

Orientation: S-SE-N-NW. The skull lay to S-SE.

Description: The grave was in the southern part of the area unearthed in 1993, under the humus deposition. It appeared in the black, moist, clayey soil as a slightly darker moist discolouration. It could be spotted directly under the ploughed layer. A roughly carved piece of limestone with rounded corners was found in the centre in a vertical position. Under it, a large, carved sandstone with semicircular end lay horizontally indicating the grave. The sides of the large tombstone were carved smooth, its bottom was 25-30 cm large. It is rough, prepared with a bushhammer. This part was originally sunk in the earth. The length of its base was $56 \mathrm{~cm}$, its height was $106 \mathrm{~cm}$, its thickness was $9 \mathrm{~cm}$ at the bottom, and $7 \mathrm{~cm}$ at the roughly carved part. One of the corners of the bushhammered part of the tombstone broke off before being placed on the grave. There are two carved regular grooves on the upper, regular part, which could hold the smaller stone.

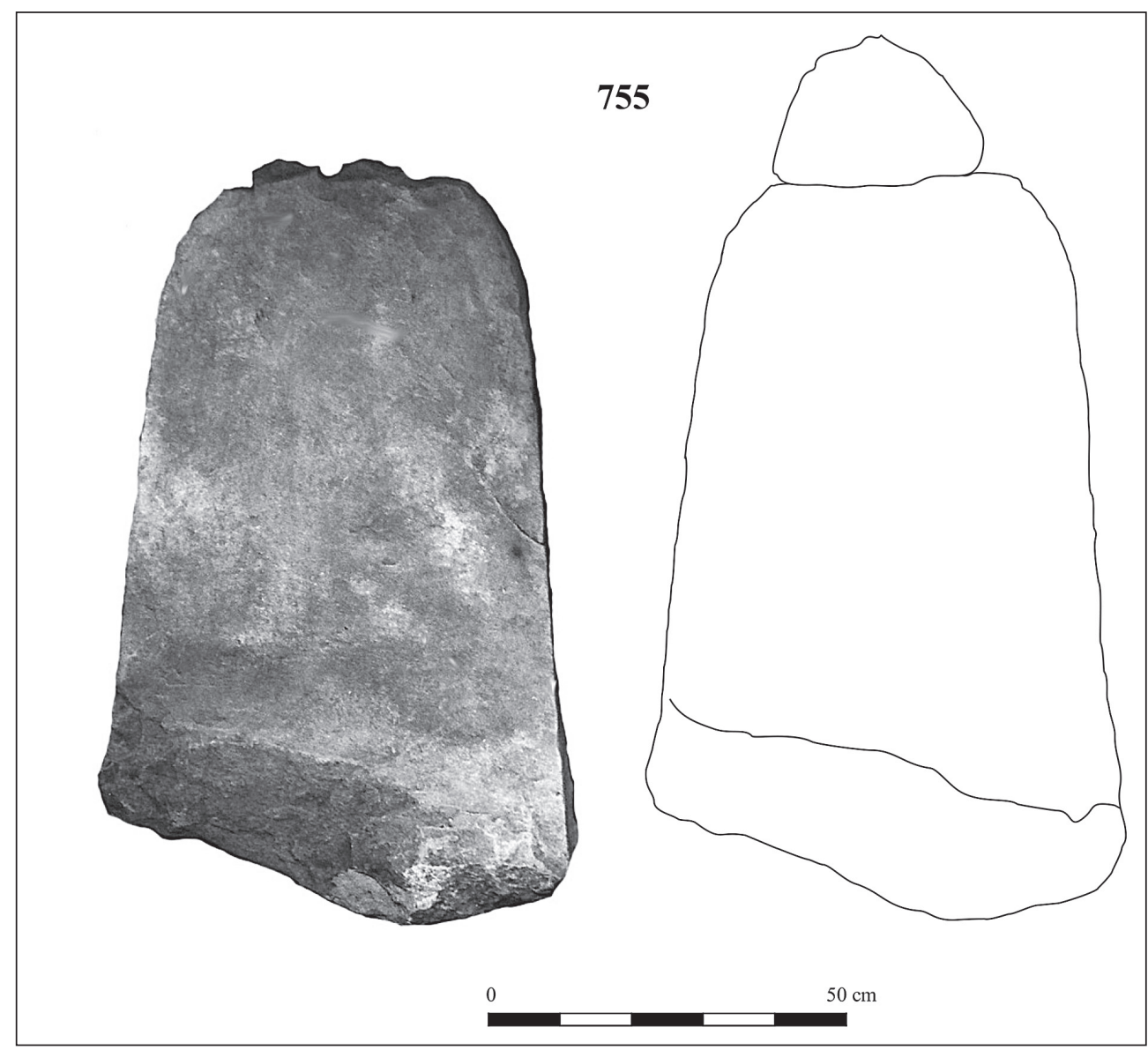

Acta Archaeologica Academiae Scientiarum Hungaricae 71, 2020 
The filling of the grave shaft was greyish black in a thickness of $20-25 \mathrm{~cm}$. Under it, the soil gradually turned lighter and moister. A darker band could be observed right above the large fallen tombstone. This band was of uneven thickness. It was thicker above the foundation of the tombstone, which is at the northern part, and narrowed at the arched end. It disappeared $30 \mathrm{~cm}$ south of the arched part. It seems that the tombstone was set up at the foot after the dead had been placed in the shaft but not yet covered with earth. After having placed the stone, the humic soil was refilled to the foundation of the tombstone and partly over the body. The direction of the burial was from the north as it can be read from the cross-section. Later the tombstone fell over the body but by that time the body had already been covered with a 10-12 cm thick, solidified layer of earth. The upper part of the tombstone fell over the larger stone slab and cracked the urn at the foot of the dead. (Fig. 36)

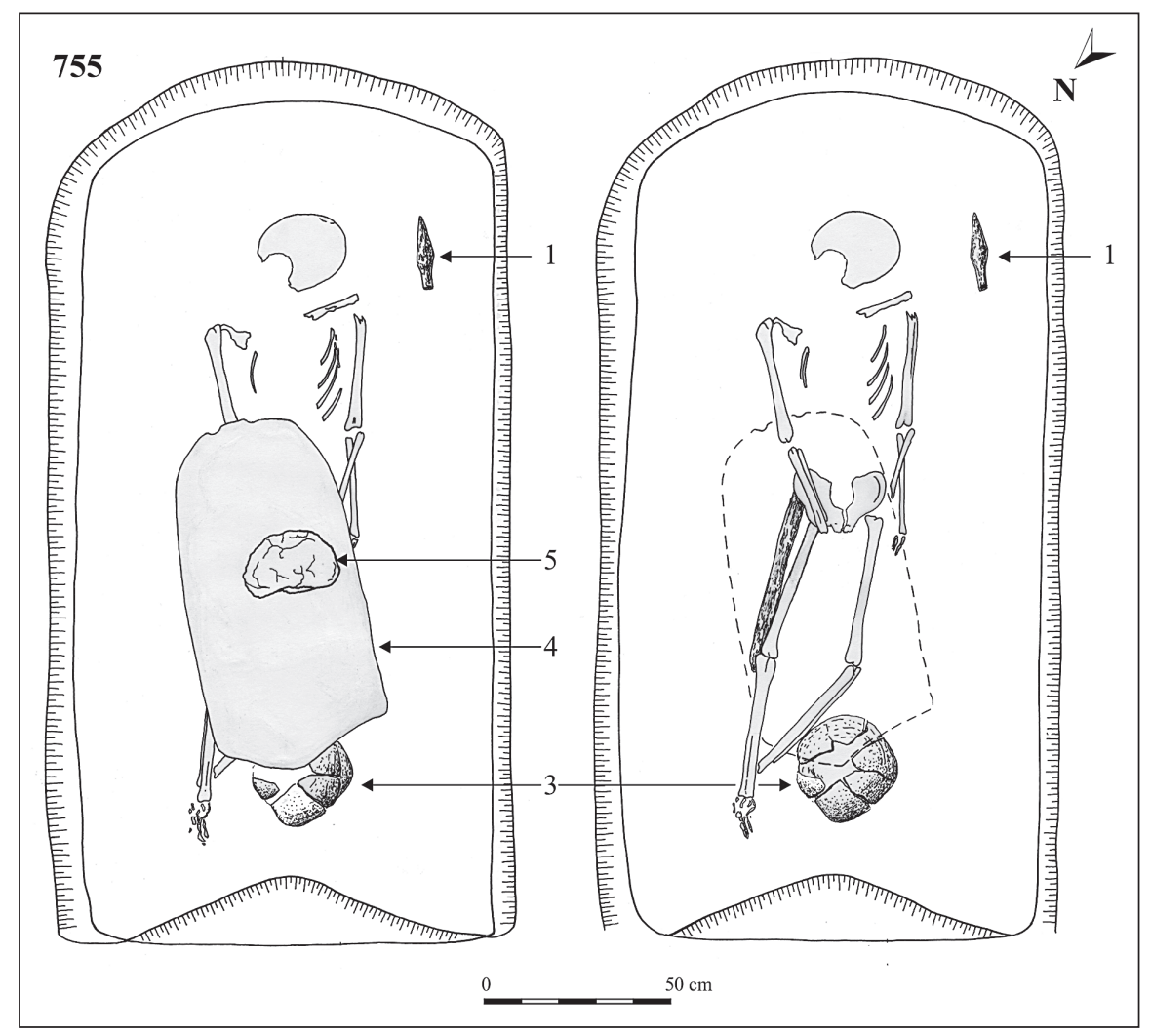

The bones of the dead were very poorly preserved. They lay partly in the grey, moist clay, which deteriorates the bones. The skull was barely more than a discolouration but it could be discerned that it originally faced east. The left shoulder was somewhat drawn up. The left-arm lay along the body, the right hand was put on the pelvis. The right leg was extended toward the north-eastern corner of the grave. The left leg was bent at the knee, the foot was found under the right leg. The irregular position of the foot was explained by the fact that the urn was placed in the grave earlier than the dead, which had to be laid a little obliquely beside the urn. The sword lay on the right side of the skeleton under the arm, the pelvis and partly under the right thighbone, and it was found only after the skeleton had been lifted. This means here that the sword, although found where it had been worn, was placed in the grave together with the urn before the body was lowered.

Measurable length of the skeleton: $169 \mathrm{~cm}$. Anthropological determination: male: 20-39 years old. ${ }^{47}$

Finds:

1. An iron spear pointing toward S-SE. It lay on the left side of the skeleton between the skull and the wall of the grave. It had a short, wide, angular blade with a midrib. H. $=13.5 \mathrm{~cm}$, Socket $1 .=4 \mathrm{~cm}$, Diam. $=2 \mathrm{~cm} .($ Fig. 21.1$)$

\footnotetext{
${ }^{47}$ Determination of K. Köhler.
} 
2. A long double-edged iron sword under the right leg. It was $69 \mathrm{~cm}$ long, the hilt was $7.8 \mathrm{~cm}$ long. The end of the hilt broke off. The scabbard had an arched terminal where the rusted remains of the suspension mount can be seen. Opposite the suspension mount coarse textile remains of thick threads can be observed. Length: $3.5 \mathrm{~cm}$. Width of the scabbard at the top: $5.5 \mathrm{~cm}$. (Fig. 21.4a-b)

3. The fragment of a small iron ring of round cross-section under the sword. Diam. = about $3 \mathrm{~cm}$. (Fig. 21.3)

4. A small iron tool in the urn. It is $10.5 \mathrm{~cm}$ long of a round cross-section at the top at the handle, the blade is oblong in cross-section. (Fig. 21.5)

\section{Grave furniture:}

1. (3) An urn at the left foot. It is black, grey in cross-section, broken to pieces, crumbling, the clay was tempered with sand. The rim is everted, the shoulder runs stepwise into the belly. M.d. $=16 \mathrm{~cm}, \mathrm{~B} . \mathrm{d} .=9 \mathrm{~cm}$, H. $=28 \mathrm{~cm}$. (Fig. 21.6)

2. (3) The fragments of a small bowl among the fragments of the urn. It is thick-walled, baked in a reducing environment, brick-coloured in cross-section, black inside and out, the clay was tempered with sand, disintegrated. M.d. $=13 \mathrm{~cm}$, B.d. $=4.8 \mathrm{~cm}$, H. $=8.8 \mathrm{~cm}$. (Fig. 21.2 and Fig. 35.5)

Grave no. 757

Orientation: $\mathrm{N}+225^{\circ}$

Shape and measurements of the grave: It was oblong-shaped with rounded corners. The width of the grave was $80 \mathrm{~cm}$ at the head and $75 \mathrm{~cm}$ at the feet. Its length measured $185 \mathrm{~cm}$. Its depth was 40 from the mechanically scraped surface, that is $110 \mathrm{~cm}$ from the actual ground surface.

Description: The Roman period ditch no. 299 intersected the grave destroying its central part. The bones were very poorly preserved, the skull appeared only as a discolouration. The bones of the chest and the upper arms

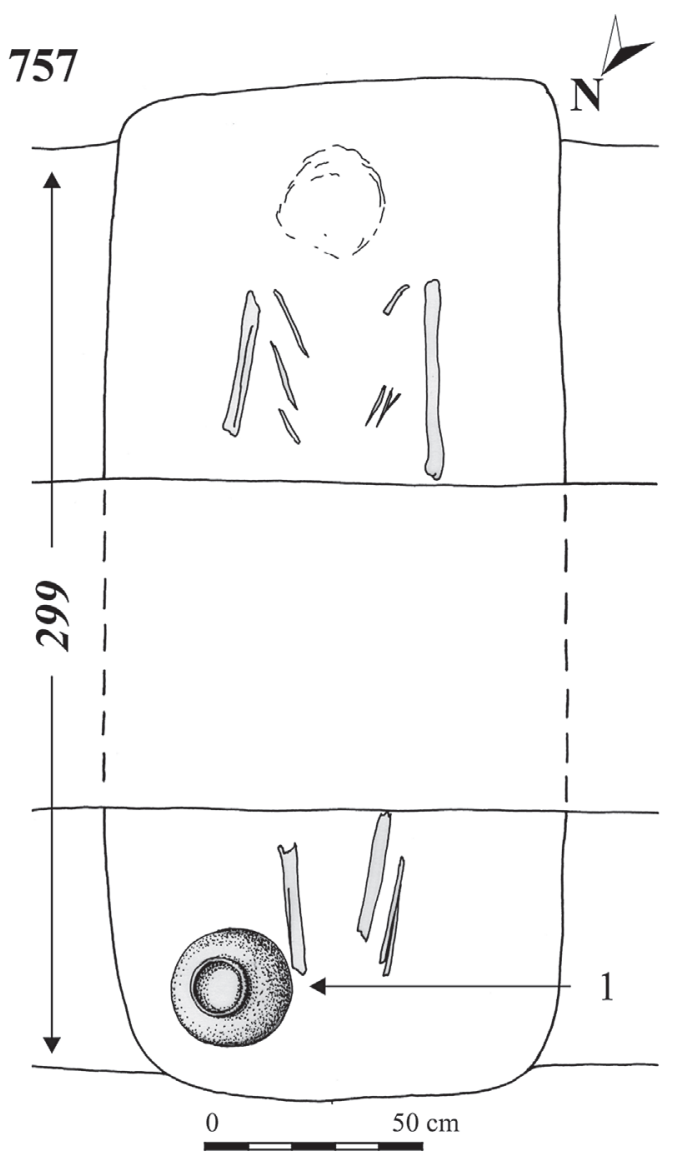


were preserved similarly to those of the leg. The rest of the skeleton was destroyed by the ditch. Anthropological determination: female(?), 20-39 years old. ${ }^{48}$

The only grave furniture was a grey vessel, so-called Linsenflasche with the mouth down next to the right foot, cracked by the weight of the earth. There are twice two grooves on the inwards narrowing neck. The lower part is flattened globe-shaped, the bottom is omphalos-shaped. The upper part is broken.

M.d. $=10 \mathrm{~cm}$, B.d. $=6 \mathrm{~cm}, \mathrm{H} .=13 \mathrm{~cm}$. (Fig. 15.11 and Fig. 34.2)

\section{Graves no. 760/A, 760/B}

\section{Grave ditch: feature no. 759}

The northern part reached under the humus deposition. The eastern and western stretches could not entirely be excavated. The western section of the ditch was $4 \mathrm{~m}$ long, the southern one was $5.9 \mathrm{~m}$ long outside and $5.4 \mathrm{~m}$ long inside in a width of $30 \mathrm{~cm}$. It was semicircular in cross-section, its width varied between 20 and $37 \mathrm{~cm}$, its depth between 7 and $16 \mathrm{~cm}$ from the surface where it appeared. The uniform filing did not contain finds.

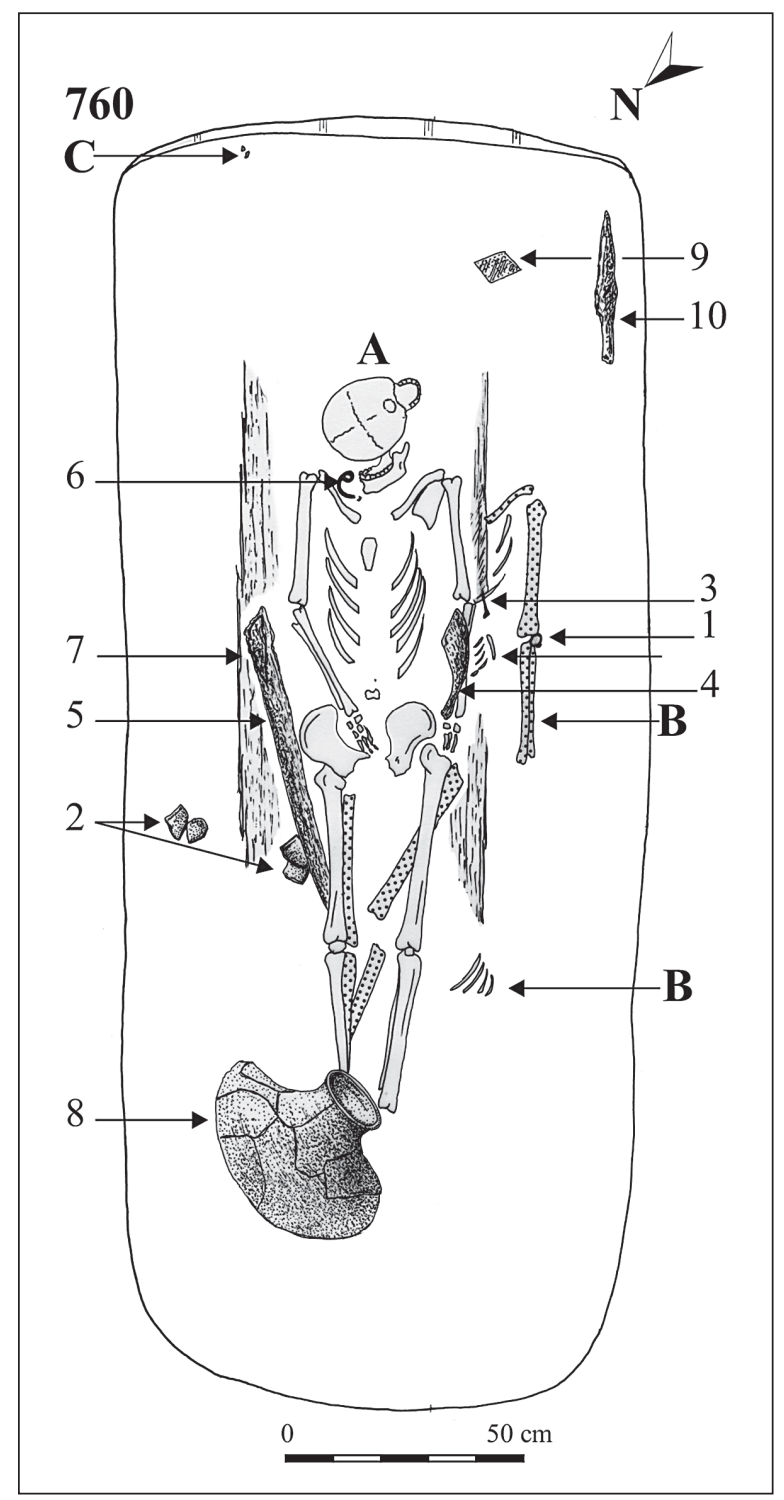

${ }^{48}$ Determination of K. Köhler. 
Orientation: $\mathrm{N}+222^{\circ}$

Description: An inhumation burial with a second burial above it. The second, later skeleton (B) was an adult male, and there was another skeleton (760/A) under it. Anthropological determination: 760/A: male, 20-30 years old; 760/B: male, gracile, 20-x years old. ${ }^{49}$

Shape and measurements of the grave: Its length was $270 \mathrm{~cm}$, its width $110 \mathrm{~cm}$ at the head, and $90 \mathrm{~cm}$ at the feet. It appeared during the scraping of the yellowish-grey sand surface $70 \mathrm{~cm}$ under the original ground surface. Its filling was somewhat darker. (The $70 \mathrm{~cm}$ means the depth of the cutting as well.) The depth of the grave was $30 \mathrm{~cm}$ at the head and $47 \mathrm{~cm}$ at the feet. The shaft was dug at an approximately right angle at the head, while the corners were rounded at the feet. The upper $20 \mathrm{~cm}$ of the filling contained densely scattered ash and charcoal pieces. In the south-eastern part of the grave, there was a discolouration (an animal burrow) of vague outlines, which disturbed the filling of the grave in the depth of $2-20 \mathrm{~cm}$. The bottom of the burial A appeared in the depth of $65 \mathrm{~cm}$.

\section{Skeleton no. 760/A}

The very poorly preserved skeleton lay on the sandy bottom of the grave. The bones were not all preserved, most of them were destroyed by the second burial. The skeleton lay extended on the back, the left leg was crossed over the right foot. The left arm was extended along the body. The bones of the chest and the skull crumbled or cracked. Some were damaged or destroyed by the second burial, some were deteriorated by the moist soil.

\section{Finds:}

1. There was a beveled bronze ring in the middle of the well-preserved left arm. It is closed, cast, solid, round in cross-section. It has a projecting round element. Diam. $=2.3 \mathrm{~cm}$. (Fig. 23.3)

2. Fragment of an iron fibula at the left chest. The returned foot and the catchplate were destroyed, only the end of the foot survived adhered to the bow. (Fig. 23.2)

\section{Grave furniture:}

3. Fragments of a thick-walled vessel partly under skeleton A, partly between the right thighbone and the wall of the grave. The surfaces of the thick bottom and wall fragments are coarse, they are dark grey. B.d. $=9 \mathrm{~cm}$, M.d. = ?, H. = ? The position of the fragments suggests that the vessel, as grave furniture, was placed on the right side of the dead, next to the pelvis. (Fig. 23.4)

\section{Skeleton no. 760/B}

It had a S-SE-N-NW orientation with the head to S-SE. It lay extended on the back. The dead were wrapped in a shroud, its traces were outlined in a width of $53-55 \mathrm{~cm}$, especially next to the skeleton. The position of the skeleton (tightly drawn up shoulders) also implied its being wrapped in a shroud. The skeleton lay extended on the back. The legs were closed. The left-arm lay along the body, the right hand was placed on the pelvis. The bones were rather poorly preserved especially those of the chest and the extremities. The jaw was in its place, while the skull was displaced by an animal burrow so that the foramen magnum was turned upside. The sword and the spear were wrapped into the shroud together with the dead, the shaft of the spear must have been broken. The urn was placed later on the wrapped dead. This is suggested by its position and by the fact that it fell on the feet of the dead under the weight of the earth thrown into the shaft. The dead was a young male, the length of the skeleton measured in the grave was $162 \mathrm{~cm}$.

Finds:

1. (4) A midribbed spearhead on the left lower arm, pointing toward the skull. The socket is round in crosssection. L. $=19 \mathrm{~cm}$, socket $1 .=5 \mathrm{~cm}$, socket diam. $=2 \mathrm{~cm}$. (Fig. 22.3)

2. (5) An iron sword and the scabbard with wood covering were placed nearly parallelly to the body pointing toward the feet. It started at the right elbow and the tip was under the right thighbone. L: $80 \mathrm{~cm}$. The length of the hilt is $11 \mathrm{~cm}$, the width of the pommel is $3.5 \mathrm{~cm}$. The upper width of the scabbard at the hilt is $5 \mathrm{~cm}$. There is a vertically placed suspension mount under the upper, arched termination of the scabbard. A small plate covers the arched terminal of the scabbard along the edge. A rivet of a semicircular head can be seen on the side of the upper part of the scabbard opposite the suspension mount. The two ends of the suspension mount are rounded, shieldshaped. The length of the suspension element is $7.7 \mathrm{~cm}$. The length of the arch is $3 \mathrm{~cm}$, it could belong to an approximately $3 \mathrm{~cm}$ wide leather strap. A roughly woven textile remain adhered to in the rust on the scabbard opposite

\footnotetext{
${ }^{49}$ Determination of K. Köhler.
} 
the suspension mount and a somewhat more finely woven textile remain can be observed in a larger rust lump. An intact and two fragmentary flat iron rings and an iron rivet rusted to the sword. (Fig. 22.a-b)

3. (6) At the right shoulder is a fragment of an iron fibula. (Fig. 22.1)

4. (7) Fragments of the sword chain beside the iron sword in a very poor condition. Fragments of iron links of round cross-sections. (Fig. 22.2)

5. (7) Fragments of two iron nails with disc-shaped heads next to the iron band. (Fig. 22.4b)

6. (7) The fragment of a small iron plate with two rivets on the backside. (Fig. 22.4a)

7. (7) The fragment of a flat iron ring of oval cross-section. Perhaps the fragments of the sword chain. (Fig. 22.6)

\section{Grave furniture:}

8. (8) The urn (broken to pieces) was placed on the feet of the wrapped dead. The urn was black inside and out, red in cross-section, the rim is everted. There is a rib in the arch of the neck and twice three parallel, horizontal ribs with deep smoothing on the neck and the shoulder. The surfaces of the vessel are strongly worn, fragmented. It was already broken when placed into the grave since it had been perforated at several places along with earlier fractures. The bottom melted away in the moist soil. M.d. $=13.2 \mathrm{~cm}$. (Fig. 23.1)

9. The fragments of a small, brick-colored, wheel-thrown, smoothed vessel were found among the sherds of the urn. It cannot be reconstructed.

Note: There was an iron spearhead in the SW corner of the grave pointing toward the western wall of the grave. (10) The spear lay outside the shroud so it probably belonged to grave A. Neither its depth nor its position connects it unilaterally to burial B. It has a midrib, the tip broke off. Length in the broken condition: $28 \mathrm{~cm}$, length of the socket: $5.5 \mathrm{~cm}$, diameter: $2 \mathrm{~cm}$. (Fig. 23.6)

2. (9) There was a split shist plate in the filling near the south-western corner of the grave. At some places, it bears green patination and traces of sharpening. (Whetstone?) (Fig. 23.5)

\section{$760 / \mathrm{C}$}

There were two milk teeth in the western corner of the 760 graves. No other child's bone was in the grave. There are several possibilities: one of the dead could have been placed with his child's missing teeth, or it is possible that the two teeth were accidentally mixed in the soil.

\section{Grave ditch no. 306}

A wide and shallow grave ditch. There was a larger oval depression in the middle of the northern section and a smaller shallower depression within it. Feature no. 466 is a grave-like discolouration in the middle section of the northern stretch of grave ditch no. 306. It probably belonged to the grave ditch. There was no grave enclosed by the grave ditch. The southern part of the ditch reached under the southern humus deposition so we could not unearth it. Yet the length of the excavated northern and eastern stretches excluded the possibility of a grave that had been dug under the level where the ditch appeared placed within the ditch. The surface was deepened to a depth of $2 \mathrm{~m}$ in a controlled cutting but no grave was found, the ground was unbroken. The length of the oval discolouration no. 466 was $230 \mathrm{~cm}$, its width $100 \mathrm{~cm}$. In its centre there was another concentric smaller depression with a diameter of $100 \times 64 \mathrm{~cm}$. The grave ditch was $60 \mathrm{~cm}$ deep and $70 \mathrm{~cm}$ deep here at the joining. The filling was uniform, identical to that of the graves. There were daub grains in the filling on the surface and the soil was slightly burnt.

The northern section of the grave ditch was $7 \mathrm{~m}$ long outside and $6.4 \mathrm{~m}$ inside, its width was $80 \mathrm{~cm}$. The eastern stretch was $5.4 \mathrm{~m}$ long outside and $5.2 \mathrm{~m}$ long inside, its width was $35 \mathrm{~cm}$. The excavated western section was $4.5 \mathrm{~m}$ outside and $4.2 \mathrm{~m}$ inside, its width was $50 \mathrm{~cm}$.

Grave ditch no. 306 was intersected by grave ditch no. $304=366$, which means that ditch no. 306 was older than the latter. Ditch no. 306 intersected ditch no. 302 encircling grave no. 360. (Fig. 24)

\section{b. Other features from the area of the Celtic cemetery}

Several archeological features have been unearthed in the Celtic cemetery. See their location: Fig. 24. Here we mention only the features that have a chronological relevance to the Celtic cemetery. 


\section{Celtic feature from the area of the cemetery}

\section{Feature no. 652}

The preserved section of the ditch ran in a N-NE-S-SW direction. In the NE part, it broke at an angle and a short section could still be followed. It contained neither archaeological nor archaeozoological material. The filling was uniform. This ditch was intersected by ditch no. $304=366$, which did not contain finds, either. Ditch no. 652 intersected grave ditch no. $363=653$ of grave no. 303 , that is ditch no. 652 was younger than grave no. 303 and its ditch no. $363=653$. At the same time, the N-NE part of ditch no. 652 was intersected by Celtic grave no. 362, which means that no. 652 was the older. Accordingly, ditch no. 652 was also dug in the Celtic period and can be dated from the time between the two Celtic features. The ditch, nevertheless, is longer where it can be observed than the grave ditches in the cemetery, which suggests that its original function in the cemetery was something else than a grave ditch.

We have to consider settlement features from later periods that sometimes disturbed the Celtic cemetery. Although they do not belong to the Celtic cemetery either chronologically or with their find material, their effects, the rearrangement of the surfaces often rendered the observation of Celtic features difficult.

\section{Disturbances in the Roman period}

Roman ditch no. 299 ran in a N-S direction across the south-eastern part of the Celtic cemetery. The ditch oven no. 300 was dug into this filled in ditch during the Migration period. The Roman ditch intersected grave ditch no. 359 encircling the Celtic grave no. 347 and the Celtic grave 364 encircled by ditch no. 365. The northern stretch of ditch no. 299 crossed and intersected ditch no. 304 = 366 running also transversally across the area. This means here that ditch no. $304=366$ was older than the Roman ditch no. 299. Ditch no. $304=366$, at the same time, is younger than grave no. 465 and its Celtic grave ditch no. 306 since ditch no. 305 intersected grave no. 465, which was, in turn, intersected by ditch no. $304=366$. Ditch no. 652 from the Celtic period was also intersected by ditch no. $304=366$, that is ditch no. 652 was older than ditch no. $304=366$.

Another section of the above-mentioned ditch no. 299 intersected grave no. 757 destroying its central part.

Ditch no. 369 ran in a N-S direction intersecting ditch no. 370. Ditch no. 370 ran in a E-W direction and it was intersected by feature no. 372 .

Ditch no. 369 intersected grave ditch no. $368=378$, which belonged to grave no. 377 . In the north it extended under the humus deposition, in the south, it disappeared after $10 \mathrm{~m}$ and did not reach grave ditch no. 450 belonging to the grave no. 464 .

\section{Disturbances in the Árpádian Era}

Some settlement features from the Árpádian Era $\left(11^{\text {th }}-14^{\text {th }}\right.$ century A. D. $)$ disturbed the Celtic cemetery but luckily not to the depth of the skeletons and the finds (see ditch no. 382 running above grave no. 752).

\section{Features of uncertain dating, which disturbed Celtic cemetery features}

The wide and shallow ditch no. 305 ran in a W-E direction across the cutting between two grave ditches (nos. $363=653$ and 302) without having any contact with them, and here it ended. This ditch was intersected by the narrow ditch no. $304=366$, which means that ditch no. 305 is earlier than ditch no. $304=366$. Ditch no. 305 also intersected the Celtic grave no. 465 , it is younger than the grave. Ditch no. $304=366$ is also younger than grave no. 364 and grave ditch no. 365 . Feature $304=366$ is older than Roman ditch no. 299 . As feature $304=366$ intersected ditch no. 305 , ditch no. 305 is older than the Roman ditch no. $299 .^{50}$

The relationship between ditch no. $304=366$ and grave ditch no. 306 see at the description of feature no. 306 .

${ }^{50}$ Features older than Roman feature no. 299 that intersected the Celtic graves can be dated from earlier phases of the Roman period or from the Celtic period, since the archaeological material they contained does not determine their accurate age. 


\section{Features of uncertain dating}

There were features in the area of the cemetery that could not stratigraphically be fitted into the structure of the Celtic cemetery or among any older or younger features.

Feature no. 758

It appeared as a short, ditch-shaped discolouration. Its length was $1 \mathrm{~m}$, its maximal width was $52 \mathrm{~cm}$. Its depth varied between 24 and $50 \mathrm{~cm}$. It narrowed downwards. Its filling was sandy, mixed, and brownish and mixed in the deeper eastern part. It contained a stone, a sherd of uncertain age, and animal bones (dog and cattle).

\section{THE INNER CHRONOLOGY OF THE CEMETERY AFTER THE EXCAVATIONS ${ }^{51}$}

It was a lucky circumstance offered during the rescue excavations ${ }^{52}$ that the interpretation of the archaeological features helps the determination of the relative chronology from more than one respect. Relative chronology is evident at the superimposed features, they provide the so-called primary relative chronological links. The graves of the grave rows also imply a chronological order among themselves. These links indicate further relationships. These are the secondary chronological associations. Besides one can compile other hypotheses as well concerning relative chronology. These latter ones can be regarded as hypothetical relativity from which the model of the chronological structure of the cemetery can be created.

The problem is that relativity means a chronological subsequence and never absolute chronological accuracy or a numerical chronological interval. In some cases, we have to use the expressions longer and shorter periods at burials in superposition, but they cannot be determined to numerical accuracy.

This model derived from the analyses is, consequently, no more than a relative chronological sketch, which can or cannot be corrected by the analogical typo-chronological determination of archaeological finds. This is determined by the homogeneity of the materials or the chronological/cultural mobility in the archaeological period. In both cases, it is worth setting up the model and analysing it.

The model has been built on various information levels, which can be completed with further hypothetical elements.

\section{a. Primary chronological links}

A primary chronological link exists between the grave and the grave ditch or another grave in central superposition. It does not mean an incidental superposition coming from an intersection but a consciously superposed burial. The superposition caused by the intersection of graves and grave elements provides another primary chronological link, similarly to the succession deduced from the surface features observed during the excavations.

\section{The contemporaneity of graves and grave ditches}

Where the graves are encircled by ditches, the graves, and the ditches are contemporary. When another grave was subsequently centrally superposed, ${ }^{53}$ the grave ditch preserved its function. The following features represent this relationship:

Grave no. 301 is contemporary to grave ditch no. 351.

Grave no. 303 is contemporary to grave ditch no. 363/653.

Grave no. 343/A is contemporary to grave ditch no. 344.

Grave no. 345/A is contemporary to grave ditch no. 346.

Grave no. 347 is contemporary to grave ditch no. 359 .

${ }^{51}$ Preliminary reports: VADAY 2006a, and VADAY 2006b.

${ }^{52}$ Here we deal with the chronology of only the cemetery long time.

${ }^{53}$ If the burial was not incidentally placed there after a fragment unearthed in 1993-94.

Acta Archaeologica Academiae Scientiarum Hungaricae 71, 2020 
Burial no. 350/A is contemporary to grave ditch no. 349 .

Grave no. 360 is contemporary to grave ditch no. 302 .

Grave no. 364 is contemporary to grave ditch no. 356.

Grave no. 377 is contemporary to grave ditch no. 368 .

Grave no. 464 is contemporary to grave ditch no. 450 .

Grave no. 744 is contemporary to grave ditch no. 745 .

Grave no. 755 is contemporary to grave ditch no. 756 .

Grave no. 760/A is contemporary to grave ditch no. 759 .

Feature (grave?) no. 375 is contemporary to the roundish ditch no. 374.

\section{Superposition of the younger graves (post-burials)}

Burial no. 343/B is younger than grave no. 343/A and consequently it is younger than ditch no. 344. Burial no. 345/B is younger than grave no. 345/A and consequently it is younger than ditch no. 346. Burial no. 350/B is younger than grave no. 350/A and consequently it is younger than ditch no. 349. Burial no. 376/B is younger than grave no. 376/A.

Burial no. 760/B is younger than grave no. 760/A and consequently it is younger than ditch no. 759 .

\section{Chronological succession derived from the intersection of graves and grave elements}

In this case, the situation is not so clear as it was in the aforementioned one. The relativ connection of more features must be fixed and in some cases, more solutions exist. If in case of variations their chronological situation could not be expressly fixed the model diverges into two or more directions. Alongside these directions probability of the model can be fixed sometimes ambiguously but in other cases only hypothetically. Occasionally further definitions never could end in an exact model. Here we can determine the relative sequence of more features.

\section{Features nos 343/A - 346 - 344 - 345/A}

Burial no. 343/A is younger than the neighbouring burial no. 345/A also with a grave ditch, since grave ditch no. 344 intersects the eastern section of grave ditch no. 346 of burial no. 345/A. Here however something must be clarified. Grave no. 345, namely has a secondary burial and the above-mentioned superposition is unambiguous only in the case of grave no. 345/A. The chronological order of graves no. 345/A and the superposed burial no. $345 / \mathrm{B}$ is unambiguous, while it is less certain if grave no. 343 is younger than the second burial no. 345/B. Theoretically, two or three versions can exist at the ambiguous chronological situations. ${ }^{54}$ In this case, we use the most probable version. When, however, the probability of two versions is 50-50\%, the model branches according to the versions. There can also be a situation when the reality of the probability of the models cannot be decided either with certainty or even hypothetically. In the above-cited case, the grave ditch was not renewed at the time of the subsequent burial, so it can be supposed that it was still visible when the second grave was superposed. ${ }^{55}$ In this case grave no. 343/A is younger than either grave no. 345/A or the subsequent burial no. 345/B.

\section{Features nos 301 - 351 - 349 - 350/A - 350/B}

Grave no. 301 and grave ditch no. 351 are contemporary, and they are younger than burial no. 350/A and its ditch no. 349, since ditch no. 351 of grave no. 301 intersects grave ditch no. 349. The succession of cremation burial no. 350/B and grave no. 350/A is also unambiguous, since grave no. 350/B was dug over grave no. 350/A. Cremation burial no. 350/B is probably younger than grave no. 301 since the central place of the neighbouring grave and grave no. 350/A under it, both enclosed by a grave ditch, were not taken into consideration at the digging

${ }^{54}$ Contemporary, younger, older. In lucky cases the observation of details can help to decide which version seems to be most correct.
${ }^{55}$ The condition of the skeletons of graves no. 345/A and $345 / \mathrm{B}$ skeleton indicates that not too much time has passed between the two burials. Post-burial does not differ from the first tomb, which also refers to a shorter period.

Acta Archaeologica Academiae Scientiarum Hungaricae 71, 2020 
of the grave. Disregarding the ritual differences we could set up another chronological model, namely that grave no. 301 and its ditch no. 350 are younger than cremation burial no. 350/B. This model is less probable than the previous one since grave no. 350/B contained a cremation burial and grave ditch no. 349 around grave 350/A could not belong to it. So the chronological implication of the superposition of the ditches cannot be correlated to the grave that is not related to the ditch. Grave no. 350/B is not in the centre of the surface encircled by the ditch, which shows that the ditch around the grave was not visible at the time of the burial and it was not renewed. ${ }^{56}$

\section{Features nos $306-360-744$}

Grave ditch no. 306 is younger than graves nos. 360 and 744, since it intersected the ditches of both graves (no. 302 of grave no. 360 and no. 745 of grave no. 744). Two models are possible here as well. According to the first one the chronological sequence if the following: grave ditch no. 306 is the youngest, followed by ditch no. 745 and its grave no. 744, then finally grave ditch no. 302 and its grave no. 360. According to the other model, grave ditch no. 306 is the youngest, grave ditch no. 302 and its grave no. 360 are older, while grave no. 744 enclosed by ditch 745 is the oldest. Regarding, however the hypothesis that burials in graves with grave ditches followed an east-west succession from the top of the hill, ${ }^{57}$ grave no. 360 bordered by grave ditch no. 302 is older than grave no. 744 with grave ditch no. 745 . This version corroborates the first model.

\section{Features nos 375 - $374-464-450$}

The fragment of round ditch no. 374 of the round dicolouration no. 375 intersects grave ditch no. 450 of grave no. 464, the round discolouration and its ditch are younger than grave no. 464 and its ditch no. 450 . Here we only conditionally linked the 464 to the tomb with the trench 450 because of its shape. If not included in the tomb, the chronological connection is only between 375 and 450 and does not apply to tomb 464 .

\section{Relativity deduced from the surface formations}

The surface formations observed during the excavations also contribute to the determination of the relative chronology of the cemetery. Graves nos 376/A and 376/B are older than the neighbouring grave no. 377, since the adjacent graves appeared in different depths. Grave no. 377 was outlined on the scraped surface, while grave no. 376/B appeared deeper. It is also evident that grave no. 376/A is older than the superposed grave no. 376/B. This relative order is completed by grave ditch no. 368 around grave no. 377, which is intersected by the younger grave no. 367 .

\section{b. Secondary relative chronological associations}

The characteristics of rite and the more accurate dating of finds help in determining the secondary relative associations. In the north, on the territory unearthed by A. Uzsoki, there were only inhumation graves. The cemetery was already biritual along the track of Road no. 83, while in the southern part, in the service territory and at the water trench, most of the graves contained cremation burials. The earliest grave in the northern part was of Late LT A features, ${ }^{58}$ while the graves found in the water trench and south of it can partly be dated from the LT C. Another possibility is that there are four rows of graves with ditch. The groups are also differentiated by a divergence in the orientation of the axes of the grave ditches. Graves and grave ditches with axes of identical orientation compose a relatively closed group of burials probably within a short chronological period. Summarizing what has been said, the following picture can be drawn, adding the position of the graves.

The first line of graves: nos $343,345,760,757.755$, and 348. The grave no. 345/A is evidently the oldest in the first row of graves. Grave no. 343, which intersects the ditch of this grave is younger. It is not clear, however,

\footnotetext{
${ }^{56}$ Grave ditch no. 351 already intersected it!

${ }^{57}$ This direction could be demonstrated from the intersect- tion.
}

${ }^{58}$ The earlier grave of burial no. 4 in A. Uzsoki's publicaing graves. 
to which grave nos 760 and 755 should be compared. It can be seen in the map of the cemetery that the axes of graves nos 343, 760, and 755 have the same direction and they are evenly distributed. So we can suppose that they composed a sequence. Burial no. 345/A and its grave ditch no. 346 are older than burial no. 345/B. Burial 345/B, at the same time, is older than grave no. 343 and its grave ditch no. 344. Burial 760/A and its grave ditch no. 759 are younger than grave 343. Grave 755 and its ditch no. 756 are younger than burial no. 760/A. As burial 760/B is obviously younger than grave no. 760/A, the relative chronological order can be continued. The relationship between burials nos 760/B and 755 is not clear, we can only suppose that the grave in superposition is younger than grave no. 755. The grave no. 348 is not exactly aligned with the others, it has no observable connection to them.

The next row runs parallel to the first: nos 301, 350/A and 347, 364, and 367. It is conceivable that cremation graves 298 and 350/B also belong to this series of graves. However, this is questionable. The grave no. 350/B is much later than the grave no. 350/A. The grave no. 301 was already dug when the grave ditch no. 349 of the grave no. 350/A was no longer visible, so a much longer time elapsed at the next burial. It should be added that cremation tombs seem to be the latest here. Grave no. 301 and its ditch no. 351 are younger than burial no. 350/A and its grave ditch no. 349. According to the structure of the cemetery, grave no. 347 and its ditch no. 359 may have been the earliest grave of the grave-row, adapting to the above mentioned first grave row.

The chronological relationship between the two rows of the group can be determined by the N-S extension of the cemetery. The relationship between the elements of the two rows of graves means another relativity, the particular chronological intervals and how the individual graves can be distributed among these intervals cannot be determined solely from the surface formations.

The third row is not very regular, it includes the next graves: nos 361, 376/A, 376/B and 379. Only superposition is certain in the row.

It is characteristic of the graves in the next group that the direction of the axes of their ditches somewhat diverges towards SE as compared to those of the former group. Here are four rows of graves. There is only one grave in the first row (no. 367). Cut the $368=378$ trench. In the second row lies the graves no. 377 and perhaps no. 342 . The third line of the second grave group consists of the grave: nos 303, 307, 362, and 464. There are two graves in the fourth row of the group: no. 360, and no. 744. But here you can see the 738 and 306 ditches, in which the graves are no longer left. The easternmost grave of the row was the burial enclosed by ditch no. 738. Here the grave itself could not anymore be observed inside the ditch, and the ditch itself is incomplete, which suggests that the erosion had destroyed the higher parts of the grave ditch.

Interpretation is the most difficult in this group since the erosion of the sandy soil on the higher altitude and the features of later periods often damaged the Celtic graves and the grave ditches. Sometimes the ditches were not even outlined. It is certain that the trench no. 306 cut the trench of the grave no. 302, and the trench of the grave no. 745 . Some of the graves were shallower than the grave ditches (see the position of grave ditches nos 360 and 306). Grave ditch no. 306 (contemporary to feature no. 466) was younger than grave no. 744 and its ditch no. 745, while the latter ones are younger than grave no. 360 and its ditch no. 302. Grave ditch no. 738 is the youngest of all. The abovementioned graves no. 298 and no. 350/B is questionable. Both are located in 2 rows of the first group, but presumably much later. There are three more graves in the north-eastern part of the cemetery (nos 737, 752, 754). These appear to be the latest inhumation graves, have no trench, and their temporal relationship to each other cannot be determined.

\section{c. Hypothetical and "floating" chronological links}

Some more observations can be made concerning the chronological situation, which is suitable for drawing consequences but the chronological links allow only the determination of a "floating chronology". This exists between the following features:

345/A - 346 - 345/B:

Ditch no. 346 of burial no. 345/A was not renewed at the time of the burial in grave no. 345/B. The uncorrected line of the ditch suggests that the ditch of the former grave was still visible at the time of the second burial, that is people took care of the grave. But the dead in grave no. 345/B was not buried exactly over the centrally placed 
grave, which suggests that the longer time must have passed between burials no. 345/A and 345/B and the pit or the mound of grave no. 345/A was not any more clearly discernible on the surface.

\section{8 - 349 - 350/A - 350/B - 301 - 351:}

Cremation burial no. 350/B did not have a grave ditch although it was partially dug over grave no. 350/A and so it lies inside ditch no. 349. The different rite and the irregular (casual) position dates cremation burial no. 350/B to a period after the row of graves with grave ditches (graves nos 350, 347, 364, and 301). It has already been suggested that the rows of graves were started from the eastern edge and they follow one another toward the west in chronological succession. Supposing the same regularity in the case of cremation burials, grave no. 350/B follows grave no. 298 in the chronological order. It should be added that cremation grave no. 298 did not have a grave ditch which supports the supposition that cremation burial no. $350 / \mathrm{B}$ was only incidentally placed inside the grave ditch. ${ }^{59}$ It has already been mentioned that the link between grave/ditch nos $301=351$ is younger than that between grave/ ditch nos 350/A-349. Including the cremation burials, cremation grave no. 298 is younger than the above-mentioned inhumation graves with grave ditches, while cremation burial no. 350/B is even younger. ${ }^{60}$

Based on the above, the relative chronology of the unearthed cemetery fragment can be illustrated after the stratigraphic sequence with the help of the Harris matrix. Naturally, it only indicates the succession of the features and does not express the absolute chronological differences between the features and does not correlate the sequence with absolute dates. The features of the same "level" illustrated in the figure along a horizontal line, but not joined by a continuous line, cannot be associated with certainty with the same absolute date.

We distinguished between burials that also contained LT A type finds. ${ }^{61}$ However, it is not necessarily present that these are earlier. Maybe these items have been in vogue for a long time. It is also conceivable that the immigrants brought it with them. In the latter case, they could also be members of the first generation in Transdanubia.

\section{STATISTICAL DATA OF THE CEMETERY}

\section{The rite of the cemetery}

The structure, the chronological determination, and ritual characteristics of the cemetery used for several generations are not simple. The following table contains the burial rite and the sex of the buried persons.

\begin{tabular}{|c|c|c|c|c|c|}
\hline \multicolumn{4}{|c|}{ Grave } & \multicolumn{2}{|c|}{ Dead } \\
\hline number & ditch & ríte & pit & sex & number \\
\hline 298 & - & Cremation & + & - & - \\
\hline $350 / \mathrm{B}$ & - & Cremation & + & - & - \\
\hline 301 & 351 & Inhumation & + & $?$ & 1 \\
\hline 303.1 & $363 / 653$ & Inhumation & + & Q & 1 \\
\hline 303.2 & $363 / 653$ & Inhumation & + & $0^{\prime \prime}$ & 1 \\
\hline 307 & - & Inhumation & + & O & 1 \\
\hline 340 & - & Inhumation & + & $?$ & 1 \\
\hline 342 & - & Inhumation & - & ○? $?^{62}$ & 1 \\
\hline $343 / \mathrm{A}$ & \multirow[t]{2}{*}{344} & Inhumation & \multirow[t]{2}{*}{+} & $O^{\prime}(?)$ & 1 \\
\hline $343 / \mathrm{B}$ & & Inhumation & & $\sigma^{\prime}(?)$ & 1 \\
\hline $345 / \mathrm{A} 1$ & \multirow{4}{*}{346} & Inhumation & \multirow[t]{2}{*}{+} & $\sigma^{\prime}(?)$ & 1 \\
\hline $345 / \mathrm{A} 2$ & & Cremation & & $?$ & 1 \\
\hline $345 / \mathrm{B} 1$ & & Inhumation & \multirow[t]{2}{*}{+} & Q(?) & 1 \\
\hline $345 / \mathrm{B} 2$ & & Cremation & & $?$ & 1 \\
\hline
\end{tabular}

${ }^{59}$ It can often be observed in Celtic cemeteries that cremation graves were also enclosed by ditches but no cremation burial with a grave ditch was discovered at Ménfőcsanak either during A. Uzsoki's former observations nor during the excavations in 1993-94.
${ }^{60}$ The cremation burials indicate a later phase in the Ménföcsanak cemetery, and the ritual difference supports the interpretation of the phenomena observed in the cemetery.

\footnotetext{
${ }^{61}$ VADAY 2006b, Fig. 6.

${ }^{62}$ Based on its spindle button.
} 


\begin{tabular}{|c|c|c|c|c|c|}
\hline \multicolumn{4}{|c|}{ Grave } & \multicolumn{2}{|c|}{ Dead } \\
\hline number & ditch & ríte & pit & sex & number \\
\hline 347 & 359 & Inhumation & + & \% & 1 \\
\hline 348 & - & Inhumation & + & O & 1 \\
\hline $350 / \mathrm{A}$ & 349 & Inhumation & + & $0^{\prime \prime}$ & 1 \\
\hline 360 & 302 & Inhumation? & - & - & - \\
\hline 361 & - & Inhumation & + & $O^{\prime}(?)$ & 1 \\
\hline 362 & - & Inhumation & + & $?$ & 1 \\
\hline 364 & 365 & Inhumation & + & Q? & 1 \\
\hline 367 & - & Inhumation & + & $?$ & 1 \\
\hline $375^{63}$ & 374 & $?$ & - & - & - \\
\hline $376 / \mathrm{A}$ & - & Inhumation & + & $?$ & 1 \\
\hline 376/B & - & Inhumation & + & $\sigma^{\prime}(?)$ & 1 \\
\hline 377 & $368=378 ?$ & $?$ & + & - & - \\
\hline 379 & - & Inhumation & + & $\sigma^{\prime}(?)$ & 1 \\
\hline 464 & $450 ?$ & $?$ & + & - & - \\
\hline 465 & - & Inhumation & + & $?$ & 1 \\
\hline 737 & - & Inhumation & & $0^{n}$ & 1 \\
\hline 744 & 745 & Inhumation & + & $\sigma^{\prime}(?)$ & 1 \\
\hline 752 & - & Inhumation & + & \% & 1 \\
\hline 755 & 756 & Inhumation & + & $0^{\prime \prime}$ & 1 \\
\hline 757 & - & Inhumation & + & Q(?) & 1 \\
\hline 760/A & 759 & Inhumation & + & $0^{\prime \prime}$ & 1 \\
\hline $760 / \mathrm{B}$ & & & + & $0^{\prime \prime}$ & 1 \\
\hline- & 306 & $?$ & - & - & - \\
\hline \begin{tabular}{|l}
- \\
\end{tabular} & 738 & $?$ & - & - & - \\
\hline
\end{tabular}

The number of graves is different just like the number of buried persons and the burials. The interrelation and variation of the diverse ritual elements are also different. Some of the graves were enclosed by ditches. Due to this complicated system, the burials will be reviewed in the following in detail in the order of the grave groups.

Few graves were in the excavation area of the cemetery-part. However, it is also clear that the inhumation graves are in a numerical majority. Due to the small number of graves, statistical analysis is not warranted, only trends can be identified.

Regarding the distribution from the aspect of the rite, burials without ditches dominate: 16 pieces, which are completed by the one superposed burials without ditches. Graves with ditches form the next largest group: 13 pieces, completed with another - perhaps trenched - grave. This also means that superposed burials were more frequent at graves with ditches than at graves without ditches.

Grave index, surface index, and content index, grave ditch indices.

The metric data of the graves are diverse. We try to compare the simple documentation data abstractly and correlate them with the data gained from the analysis of the cemetery and the graves to find out if any correspondences can be demonstrated.

The surface index can be measured from the metric data. Actually, the data measured on the surface of observations determine it. The secondary surface index calculated from the metric data of the open bottom of a grave completed with the excavated depth determines the three-dimensional shape of the grave. These data, however, are important only if the shape of the grave is not a regular prism.

The volume index can be calculated also from the metric data. The problem is that it is calculated from the surface where the graves appeared or from which they were excavated, or mostly from where they are definitely out-

${ }^{63}$ Grave? 
lined. We cannot count on the upper parts that were destroyed by ploughing. It means that the content index does not match the original content index, it will always be smaller. Still, it is worth calculating it since the ploughed soil was of approximately the same thickness in most of the sites and so the content indices of the graves can be compared. ${ }^{64}$

Finally, in the case of graves, the grave index is the abstract expression of the shapes and proportions of the graves.

In the case of grave ditches, the index of the territory enclosed by the ditch can be compared. Complete or incomplete data series of grave ditches could be used in the case of the following graves: 301 , ditch no. 306 (without grave), 342(?), 343, 345, 347, 350/A, 360, 364, 377, 464, ditch no. 738 (without grave), 744, 760, 755.

\section{The metric data of the graves and grave elements}

There is a wide distribution of the metric data in the cemetery. We used the data collected according to the following aspects of the analysis:

1. Grave index: the proportion of the length and the width of the grave.

2. Surface index: the product of the length and width data measured at the appearance of the regular graves. Where the above data were different on the surface where the grave appeared and on the bottom of the grave, the upper and the lower indices are given in $\mathrm{m}^{2}$.

3. Volume index: the volume of the grave from the level of the appearance in $\mathrm{m}^{3}$.

4. Enclosed territory: the territory enclosed by the ditch in $\mathrm{m}^{2}$.

The data:

\begin{tabular}{|c|c|c|c|c|c|c|}
\hline grave no. & ríte & $\begin{array}{l}\text { grave } \\
\text { ditch }\end{array}$ & grave index & surface index & volume index & $\begin{array}{l}\text { enclosed } \\
\text { territory }\end{array}$ \\
\hline 298 & cremation & no & - & $0.75 \mathrm{~m}^{2}$ & $0.075 \mathrm{~m}^{3}$ & - \\
\hline 301 & inhumation & yes & 2.12 & $3.06 \mathrm{~m}^{2}$ & $2.60 \mathrm{~m}^{3}$ & $48.91 \mathrm{~m}^{2}$ \\
\hline $303.1+2$ & inhumation & yes & 1.91 & $2.53 \mathrm{~m}^{2}$ & $1.51 \mathrm{~m}^{3}$ & $18.48 \mathrm{~m}^{2}$ \\
\hline 306 & $?$ & yes & - & - & - & $33 \mathrm{~m}^{2}$ \\
\hline 307 & inhumation & no & 2,5 . & $1.23 \mathrm{~m}^{2}$ & $0.55 \mathrm{~m}^{3}$ & - \\
\hline 340 & inhumation & no & $\begin{array}{l}\text { upper: } 2.42, \text { lower } \\
2.5\end{array}$ & $\begin{array}{l}\text { upper: } 1.2 \mathrm{~m}^{2} \text {, lower } \\
0.62 \mathrm{~m}^{2}\end{array}$ & $0.65 \mathrm{~m}^{3}$ & - \\
\hline 342 & inhumation & no & - & - & - & - \\
\hline $343 / A+B$ & inhumation & yes & 1.77 & $3.24 \mathrm{~m}^{2}$ & $0.77 \mathrm{~m}^{3}$ & $26.73 \mathrm{~m}^{2}$ \\
\hline $345 / \mathrm{A} 1+2$ & biritual & yes & 2.04 & $2.94 \mathrm{~m}^{2}$ & $1.67 \mathrm{~m}^{3}$ & $14.62 \mathrm{~m}^{2}$ \\
\hline $345 / \mathrm{B} 1+2$ & biritual & see $345 / \mathrm{A}$ & 2.13 & $2.7 \mathrm{~m}^{2}$ & $1.026 \mathrm{~m}^{3}$ & see 345/A. \\
\hline 347 & inhumation & yes & $\begin{array}{l}\text { upper: 2, lower: } \\
2.63\end{array}$ & $\begin{array}{l}\text { upper: } 3.125 \mathrm{~m}^{2}, \\
\text { lower: } 2.37 \mathrm{~m}^{2}\end{array}$ & $1.51 \mathrm{~m}^{3}$ & $28 \mathrm{~m}^{2}$ \\
\hline 348 & inhumation & no & 2.47 & $1.54 \mathrm{~m}^{2}$ & $0.24 \mathrm{~m}^{3}$ & - \\
\hline 350 & inhumation & yes & 265 & $4.9 \mathrm{~m}^{2}$ & $3.92 \mathrm{~m}^{3}$ & $19.95 \mathrm{~m}^{2}$ \\
\hline 360 & $?$ & yes & $?$ & $?$ & $?$ & $37.65 \mathrm{~m}^{2}$ \\
\hline 361 & inhumation & no & 196 & $3.06 \mathrm{~m}^{2}$ & $1.23 \mathrm{~m}^{3}$ & - \\
\hline 362 & inhumation & no & 31 & $1.63 \mathrm{~m}^{2}$ & $0.41 \mathrm{~m}^{3}$ & - \\
\hline 364 & inhumation & yes & 26 & $2.16 \mathrm{~m}^{2}$ & $1.25 \mathrm{~m}^{3}$ & $28.32 \mathrm{~m}^{2}$ \\
\hline 367 & inhumation & no & upper: 24 , lower: 21 & $\begin{array}{l}\text { upper: } 2.28^{2} \text {, } \\
\text { lower: } 1.98^{2}\end{array}$ & $1 ., 54 \mathrm{~m}^{3}$ & - \\
\hline 375 & $?$ & yes & - & - & - & $14.11 \mathrm{~m}^{2}$ \\
\hline $376 / A+B$ & inhumation & no & $\begin{array}{l}\text { upper: 171, lower: } \\
234\end{array}$ & $\begin{array}{l}\text { upper: } 5.25 \mathrm{~m}^{2} \text {, } \\
\text { lower: } 3.1 \mathrm{~m}^{2}\end{array}$ & $3.51 \mathrm{~m}^{3}$ & - \\
\hline 377 & empty & yes & 287 & $1.84 \mathrm{~m}^{2}$ & $1.23 \mathrm{~m}^{3}$ & - \\
\hline 379 & inhumation & no & 162 & $4.16 \mathrm{~m}^{2}$ & $1.87 \mathrm{~m}^{3}$ & - \\
\hline
\end{tabular}

${ }^{64}$ In the individual cases it should be considered if soil erosion had the same effect in the entire territory in the time following the burial.

Acta Archaeologica Academiae Scientiarum Hungaricae 71, 2020 


\begin{tabular}{|l|l|l|l|l|l|l|}
\hline \multicolumn{1}{|c|}{ grave no. } & \multicolumn{1}{|c|}{$\begin{array}{c}\text { gríte } \\
\text { ditch }\end{array}$} & \multicolumn{1}{c|}{ grave index } & surface index & \multicolumn{1}{c|}{ volume index } \\
territory
\end{tabular}

1. Cremated dead in a simple grave without a grave ditch could be found in graves nos 298 and 350/B. Biritual, cremated, and contemporary inhumation burials were found in graves enclosed by ditches in two cases: in burials nos 345/A1 and 345/A2 and in the superposed later burials nos 345/B1 and 345/B2, which were enclosed by the same grave ditch.

2. Cremation, probably overground burial with a round ditch was no. 375 with ditch no. 374 . Since neither archaeological nor anthropological material was the existence of a grave can be deduced only from the measurements and the surface formations.

3. Simple inhumation grave without a ditch containing a single skeleton was found in 13 cases (features $\operatorname{nos} 307,340,342,348,361,362,367,379,465,737,752,754$ and 757). and $376 / \mathrm{B}$.

4. There was only one simple inhumation grave without a ditch with a superposed burial: burials nos 376/A

5. There were six instances of inhumations graves with ditches and a single skeleton (features nos 301 , $347,360,364,744$, and 755).

6. There were two symbolic (?) burials with empty grave shafts: feature no. 377 with a ditch and feature no. 464 without a ditch. ${ }^{65}$

7. There was only one inhumation grave with the grave ditch and two contemporary burials: nos 303.1 and 303.2.

8. Inhumation burial inside a ditch with two contemporary burials occurred in a single case: nos 343/A and 343/B and 760/A and 760/B.

In the first stage the indices of all the inhumation and biritual graves are illustrated in the graph:66

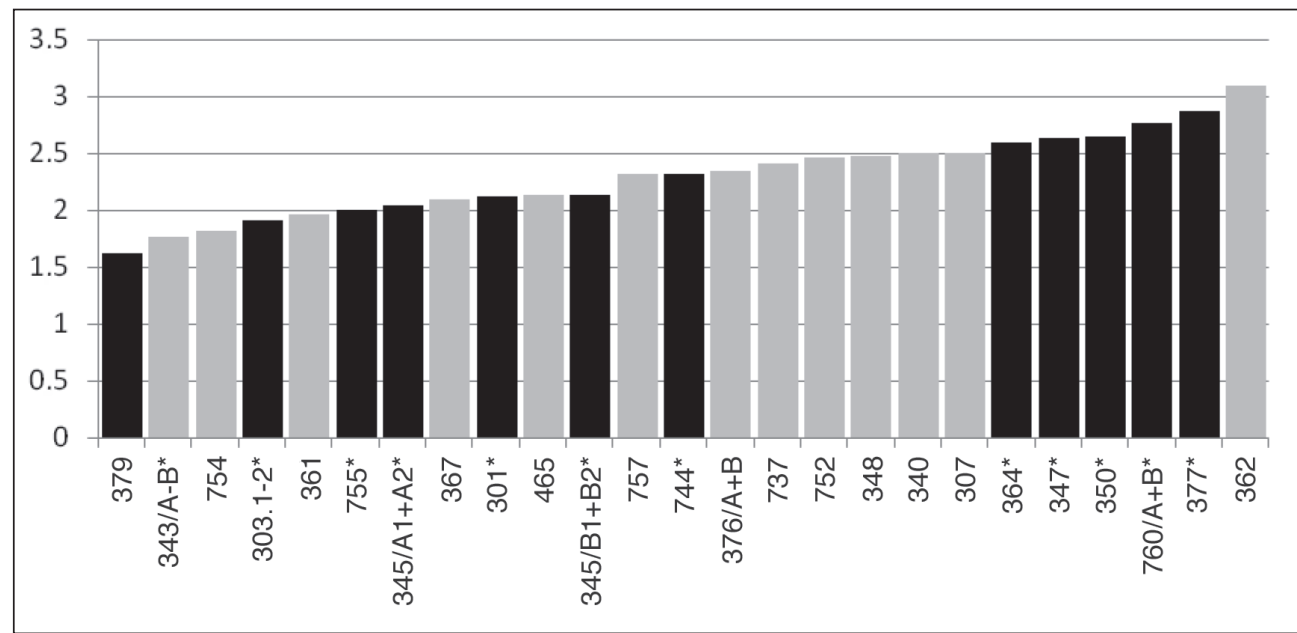

${ }^{65}$ The size and the proportion of both shafts imply skele-

${ }^{66}$ The graves marked by $*$ in the graph have ditches. tons in extended positions. 
Features with superposed graves have two different grave indices if the grave index of the second burial is different from that of the earlier one. According to the above graph, the grave indices vary between 1.6 and 3.2 at Ménföcsanak. The distribution is rather even, no great anomaly can be observed. The distribution of the grave indices is not influenced by rite, the graves with ditches and the "unmarked" burials do not compose groups of identical measurements until index value 2.4. Five burials fall between 2.4 and 2.5, none of them have superposed burials. Four graves can be found between 2.6 and 2.9. They are the graves with ditches, which contained single or superposed burials.

The grave index and the surface index are logically correlated since both are calculated from surface data. Yet they are different, which supports the fact that the grave index is independent of the size of the graves, while it is dependent on the proportions of the measurements and can be proximally evaluated. Consequently, the above illustrated grave indices must be compared to the surface indices to see if there is any correspondence within the groups of the grave types. First, the graves without ditches are listed:

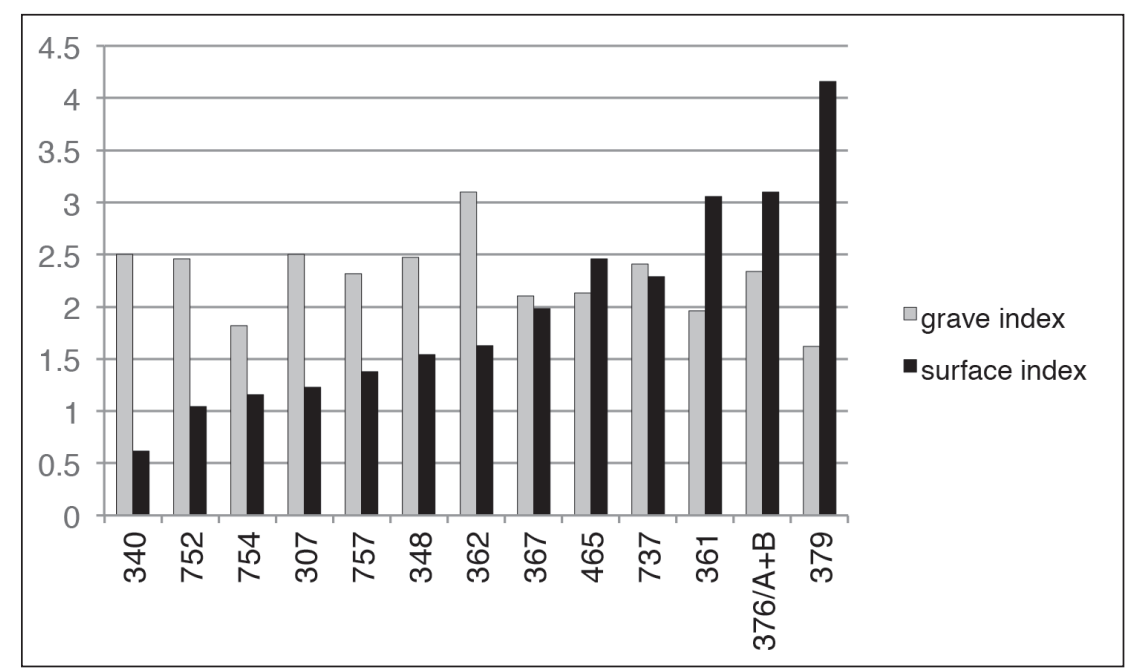

Listing the data in the growing order of the surface index, the grave indices do not show a homogenous distribution. This means that the subjectively chosen population order hinders the evaluation of the data. (The groups are shown in the graph according to the growing order of the surface indices.)

The same can be observed at the graves with ditches:

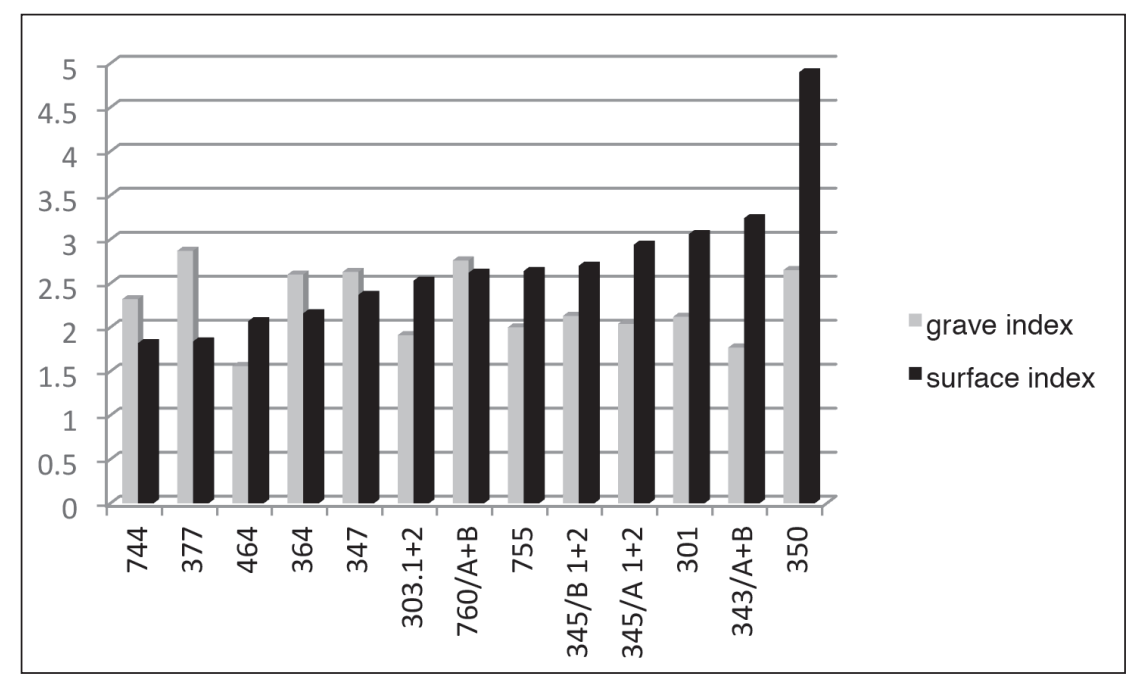




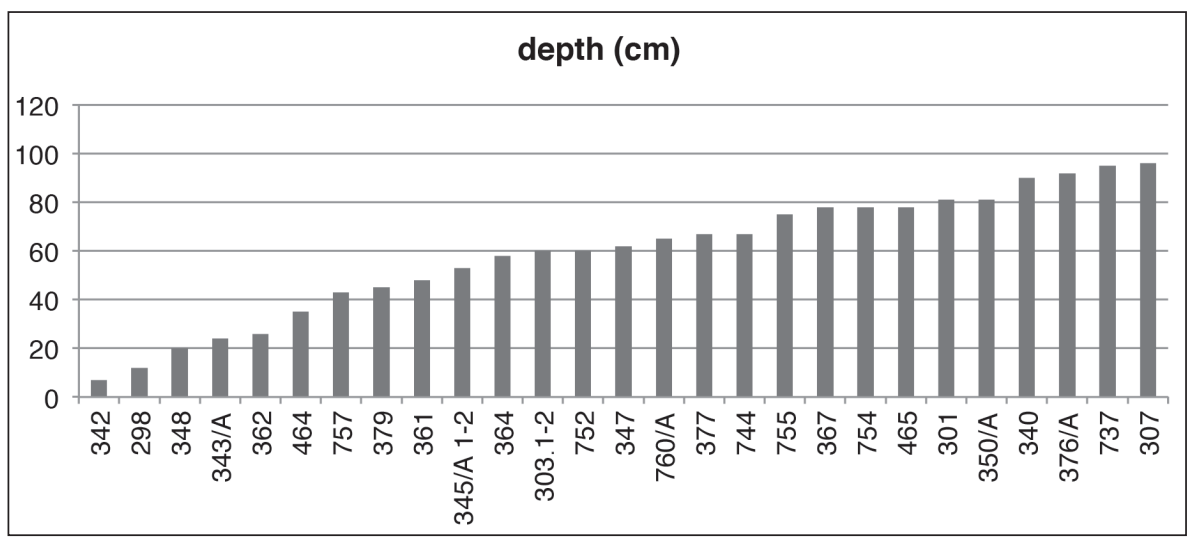

Finally, the depth of the graves is shown in the following graph:

It is a rather regularly rising curve with a balanced absolute frequency. Similarly to the above instance, it is not worth calculating relative frequency. When several cemeteries can be compared, the curves of relative frequencies could be compared. The only thing one must consider is that the original floor level cannot be observed any more because of agricultural cultivation. Accordingly, the relative frequency of the absolute values on the axis showing the number of samples is modified according to the diverse features of the individual sites.

We have to note, that the grave pits no. 377 with a ditch and no. 464 without ditch were empty, which was not without precedent on this archaeological site because the grave no. 6 excavated by A. Uzsoki in 1967 contained neither skeleton nor ashes. ${ }^{67}$ These could be symbolic or robbed burials, which has many known analogies in other necropolises. ${ }^{68}$

It is conspicuous that the inhumation rite unambiguously dominates in the known part of Ménföcsanak cemetery. 12 individuals were unearthed by A. Uzsoki from 10 inhumation graves between 1967 and $1968 .{ }^{69}$ Next to his excavation 29 inhumation burials were found by A. Vaday beside two cremation graves, one uncertain burial and other robbed or empty pits in the excavated section of Road No. 83 between 1993 and 1994. Later as we are informed from preliminary reports at least another 230 La Tène graves were uncovered by I. Egry in more campaigns between 1997 and 2006 in Ménföcsanak necropolis. This recently excavated part of the cemetery is biritual, where the rites were distributed in as half or cremation and half of the inhumation. ${ }^{70}$ Most human skeletons were found in an extended supine position. The only exception is the grave 10, which was lying in a crouched position on the right side with the arms drawn up in front of the face. ${ }^{71}$ The inhumation graves are regularly oriented northsouth or northwest-southeast. It means particularly that the head oriented to the south and the feet to the north. The standard grave pit for inhumation burials had an oblong rectangular plan with vertical walls and - more or less - flat bottom. The use of wood, perhaps wooden board or coffin was recorded in grave 301 and $760 .{ }^{72}$

Double graves with different funerary rites appear in many La Tène cemeteries in the Carpathian Basin ${ }^{73}$ and other regions. ${ }^{74}$ In some cases, burials were placed superimposed, like in the double burial from Pişcolt, where an adult was placed above a warrior, ${ }^{75}$ or from Szentlörinc, where a child (boy?) was buried under an adult female (mother?). ${ }^{76} \mathrm{~A}$ temporary succession of the graves could be observed, with cases of disturbance or partial overlapping of the burials and their enclosure in Ménföcsanak. ${ }^{77}$ Various examples of superposition are known in other La Tène necropolises - for example - from Slovakia. ${ }^{78}$

${ }^{67}$ UZSOKI 1987, 29

${ }^{68}$ Symbolic and totally robbed burials also documented e. g. in Gyöngyös cemetery: TANKÓ et al. 2016, 310.

${ }^{69}$ UzsOKI 1987, 13-29.

${ }^{70}$ EgRY 2007, 33-34.

${ }^{71}$ UZSOKI 1987, 20.

${ }^{72}$ Traces of wooden coffin, box or other counstruction were found other La Tène cemeteries in Northeast-Hungary: e. g. grave No. 1057 in Ludas-Varjú-dủlő, see SzABÓ-TANKó 2012, 71, Fig. 112.

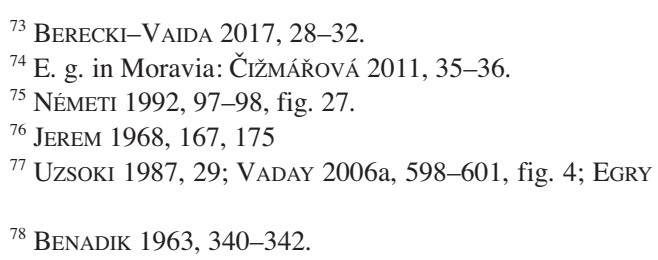


Tombstone (Fig. 36)

Large limestone and a semicircular piece of sandstone were found in the filling of the grave 755 . This roughly carved piece of limestone with rounded corners was found in the centre in a vertical position. Under it, a large, carved sandstone with semicircular end lay horizontally indicating the grave. The situation of stones suggests us it could be a stood tombstone which was fallen in the grave pit. The sides of the large tombstone were carved smooth, its bottom was $25-30 \mathrm{~cm}$ large. It is rough, prepared with a bushhammer. This part was originally sunk in the earth. The length of its base was $56 \mathrm{~cm}$, its height was $106 \mathrm{~cm}$, its thickness was $9 \mathrm{~cm}$ at the bottom, and $7 \mathrm{~cm}$ at the roughly carved part. One of the corners of the bushhammered part of the tombstone broke off before being placed on the grave. There are two carved regular grooves on the upper, regular part, which could hold the smaller stone. A darker band could be observed right above the. This band was of uneven thickness. It was thicker above the foundation of the tombstone, which is at the northern part, and narrowed at the arched end. It disappeared $30 \mathrm{~cm}$ south of the arched part. It seems that the tombstone was set up at the foot after the dead had been placed in the shaft but not yet covered with earth. After having placed the stone, the humic soil was refilled to the foundation of the tombstone and partly over the body. Later the tombstone fell over the body but by that time the body had already been covered with a 10-12 cm thick, solidified layer of earth. The upper part of the tombstone fell over the larger stone slab and cracked the urn at the foot of the dead. The using a large tombstone in burial rite was not unprecedented in the Eastern Celtic cultural circle. A similar large stone was discovered in two graves in the recent excavation in Göttlesbrunn in Austria. ${ }^{79}$ Moreover, one of them from Göttlesbrunn was a similar size to Ménfőcsanak stele, and the other consisted of a stone slab and a structural element such as in Ménföcsanak grave. Various forms of gravestones and stelae are known from burial sites in the La Tène culture, especially in their western areas, ${ }^{80}$ and in individual cases also from the East. ${ }^{81}$

\section{TYPOLOGICAL AND CHRONOLOGICAL CLASSIFICATION OF FINDS}

\section{Jewelry and clothing accessories}

1. Fibulae

Bird shaped bronze fibulae were found in grave 345.B1 (Fig. 9.1) and 367 (Fig. 16.2). Both of these fibulae have similar wide bow and bird head stylized leg with engraved geometrical decoration on it and crossbow type spiral spring. The analogies of these bird head fibulae ${ }^{82}$ are known in the Late Iron Age cemetery of Csepel ${ }^{83}$ in Hungary, moreover the Early La Tène phase of Szentlörinc cemetery, ${ }^{84}$ where it appears together with either iron Certosa or iron Eastern Alpine Zoomorphic fibulae. ${ }^{85}$ Furthermore, more examples of bird-shaped fibulae were found in Sanski most ${ }^{86}$ in Bosnia-Herzegovina, Franzhausen ${ }^{87}$ in Lower-Austria, and the fortified settlement of Závist $^{88}$ in Moravia. A common feature of these analogies that the leg bent above the bow and visualize a stylized bird head. ${ }^{89}$ On the other hand, this type has 'paukenartig' prolate bow and leg, so Thomas Stöllner identified it as an Early La Tène schema of 'Fusspaukenfibel'. ${ }^{90}$ It was stated before that the Early La Tène schema bird head or drum fibulae are developed from the Early Iron Age 'Doppelpaukenfibel' which was commonly widespread in the territory of Northeast-France, Southwest-Germany, and Switzerland in the Late Hallstatt period. ${ }^{91}$ One of the interesting analogy is the fibula from Dürnberg which has a zoomorphic bird head on the leg and its bow decorated as stylized fish. ${ }^{92}$ It seems that this piece is an example of the transition between the Late Hallstatt period drum fibulae and the Early La Tène schema decorated bird fibulae. Summarizing all the closest analogies of the bird head fibulae

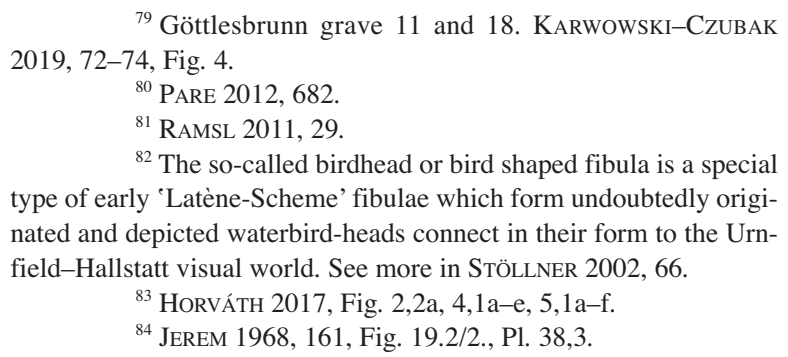

${ }^{79}$ Göttlesbrunn grave 11 and 18. KARWOWSKI-CZUBAK 2019, 72-74, Fig. 4.

${ }^{80}$ PARE 2012, 682.

${ }^{81}$ RAMSL 2011, 29.

${ }^{82}$ The so-called birdhead or bird shaped fibula is a special type of early 'Latène-Scheme' fibulae which form undoubtedly originated and depicted waterbird-heads connect in their form to the Urnfield-Hallstatt visual world. See more in STÖLLNER 2002, 66.

${ }^{83}$ HoRvÁth 2017, Fig. 2,2a, 4,1a-e, 5,1a-f.

${ }^{84}$ JeREM 1968, 161, Fig. 19.2/2., Pl. 38,3.

${ }^{85}$ See the latest chronological study of the Szentlörinc cemetery in SCHNEIDER 2019.

${ }^{86}$ Fiala 1899, 92-93, Fig. 107, 111.

${ }^{87}$ Neugebauer 1992, 69.

${ }^{88}$ TREFNÝ 2016, 158, Fig. 7,1-2.

${ }^{89}$ Binding 1993, 40-41.

${ }^{90}$ STÖLlNER 2002, 68-70.

${ }^{91}$ Bergmann 1958, 37-40, Abb. 3/VI, Karte 9-10.

${ }^{92}$ Moser et al. 2012, 114, 187-188, Grab 216/49. 
uncovered at Ménföcsanak can be dated to the LT A phase of Early La Tène period ${ }^{93}$ and their geographical spread can be localized in southern Germany, Bohemia, and Austria, as well as the north-western part of the Carpathian Basin and Bosnia-Hercegovina in the north-western Balkan. ${ }^{94}$

Bronze plate with geometric punched decoration pendant was in grave 367 (Fig. 15.3). We can conclude from the grave context of this find that it was fastened to the spring of above mentioned bird-head fibula (Fig. 15.2). Similar trapezoidal bronze plate pendant is known from Celtic burials in Pilismarót-Basaharc ${ }^{95}$ and Solymár $^{96}$ in Hungary, as well as Mannersdorf ${ }^{97}$ and Dürrnberg ${ }^{98}$ in Austria. Many analogies are also published from Čurug, ${ }^{99}$ Grobnik, ${ }^{100}$ and Osijek ${ }^{101}$ in the northwestern territory of Balkan. These pendants were usually connected to or discovered in the same context with Early La Tène fibulae, so these are the representative findings of the Early La Tène Period. ${ }^{102}$

Two Early La Tène wire fibulae with symmetrical bow - one of made of iron (Fig. 13.1) and the other made of bronze (Fig. 13.2) - were found in grave 350/A. These could be identified - at first sight - as Marzabotto fibulae, ${ }^{103}$ which chief characteristic is the high and symmetrical bow, the coils are large and two (or four) in number, and the foot runs parallel to the pin. ${ }^{104}$ However, many detailed variations are possible within this general formula, especially as far as foot element and final are concerned. ${ }^{105}$ This element may take the form of the globe as we can see on the example from Ménföcsanak. It has to mention that the large coils of the Ménföcsanak fibulae are similar to the Pottenbrunn-Horný Jatov type,${ }^{106}$ which has a known example in, ${ }^{107}$ but the chief characteristic elements of bow and foot of fibulae from Ménföcsanak are undoubtedly different. On the contrary, it should be noted that the fragment of iron fibula from grave 298 (Fig. 2.2) has a large coil and short bow which is somewhat similar to the Pottenbrunn-Horný Jatov type. ${ }^{108}$

The fibula from grave 345/A1 (Fig. 10.2) has a well balanced arch-bow profile which is slightly different from the known analogy in Münsingen, ${ }^{109}$ but it is similar in form and decoration to the fibulae found in Vícemilice in Moravia. ${ }^{110}$ The difference can only realize the character of the foot, and the analogy for this form can be quoted from Tuchomyšl. ${ }^{111}$ These analogies are the emblematic types of the so-called pre-Duchcov horizon, which was recognized by Czech researchers. ${ }^{112}$ It has to refer to they separated a transitional horizon before the emergence of Duchcov - or Dux after the German name of the eponym site - type fibulae, which was defined as La Tène B1a phase before the classical Duchcov horizon, that is La Tène B1b phase. ${ }^{113}$ The pre-Duchcov horizon was first detected only in the Czechia and Moravia, but its existence has since been proven in the Rhine region, ${ }^{114}$ Bavaria, ${ }^{115}$ Austria, ${ }^{116}$ Silesia, ${ }^{117}$ and also in Slovakia. ${ }^{118}$ This chronological stage is distinguishable in burials, where several well-dated artifacts are recorded in contrast to settlements where the ceramic finds are less affected by rapid stylistic changes

2012, 188.

93 Jerem 1996, 106; STÖLlner 2002, 70; Moser et al.

${ }^{94}$ DuLĘBA 2014, 321-322, Fig 12.

${ }^{95}$ BognÁR-KutZiÁN 1975, Pl. 5,1.

${ }^{96}$ MARÓTI-KeCSKÉS 2008, 55, Fig. 5.

${ }^{97}$ RAMSL 2011, 133, Taf. 79,7b.

${ }^{98}$ PenNinger 1972, Taf. 24,B3.

99 Todorović 1974, T. III.1-3; BognÁR-KutZián 1975,

30.

${ }^{100}$ LuUbić 1889, Pl. 33, 246; HunYAdy 1944, Fig. 1,1.

101 Todorović 1975, Abb. 13.

${ }^{102}$ JEREM 1996, Fig. 2,1-2.

${ }^{103}$ GIESSLER-KRAFT 1944, 38-39: Drathfibeln mit symmetrisch gebogenem Bügel.

${ }^{104}$ DeHN-STÖLLNER 1996, 17.

${ }^{105}$ HoDSON 1968, 35.

${ }^{106}$ RAMSL 2002, 73-74.

${ }^{107}$ HunYADY 1944, Taf. 22,7.

${ }^{108}$ This fragment of fibula is similar to another example form Bajč-Vlkanovo: BenAdík 1962, 447, Pl. XII, 5.

${ }^{109}$ There is a sharply angled roof-bow profile of fibula 673 in tomb 6 , but in an asymmetrical version, and the foot is much longer. HoDSON 1968, 35, T. 6.673. Analogy for this form may be quoted from Nebringen: KRÄMER 1964, Taf. 8,2.
${ }^{110}$ Meduna 1965, Fig. 226, 1a-4b, 227, 2a-b.

${ }^{111}$ HolodŇÁK-WaldHauser 1984, Fig. 4,1.

${ }^{112}$ An early phase before the Duchcov horizon was recognized by J. Meduna at first: MedunA 1965, 819-822.

${ }^{113}$ The pre-Duchcov horizon - Předduchcovský or Vorduxer as they first mentioned - was defined by P. Holodňák and J. Waldhauser when they analysed thoroughly some Early La Tène graves in Czechia and Moravia. They emphasized that an early archaeological horizon can be identified before the hiding of the Duchcov treasure and it is represented by the slowly disappearing La Tène A (e. g. bird head) fibulae as well as the just emerging La Tène B types (typologically the most archaic fibulae found in the Duchcov treasure): HoLODŇÁK-WALDHAUSER 1984, 31-48. Similar to the history of the Duchcov-type fibulae, it has been identified a developmental phase by J. Bujna, which is correspond to the pre-Duchcov horizon in the typological classification of Münsigen fibula and it is primary detectable in Switzerland: BuJNA 1998, 185-186.

${ }^{114}$ MÖLLER 2000, 409-413.

115 TAPPERT 2007, 183; BAGLEY et al. 2010, 73.

${ }^{116}$ RAMsl 2011, 140

${ }^{117}$ DulęBa 2019, 378-381.

${ }^{118}$ BARTÍK-ČAMBAL 2014, 98. 
and well-dated assemblages are barely available. ${ }^{119}$ An exception to this - for example - the rural settlement at Szajk in Hungary where a characteristic LT B1a type fibula was found. ${ }^{120}$ Good analogies of it are known from Szentlőrinc, ${ }^{121}$ as well as Sisak and Velika in the North-Balkan. ${ }^{122}$ Based on the known distribution of objects it is not surprising that it is a new example for pre-Duchcov type fibula which uncovered in grave no. 345/A1 in Ménföcsanak.

The other fibula from grave 345/A1 (Fig. 10.2) has a good analogy in the cemetery of Hostomice. The shape of the bow, the construction of coils, and the spherical element on bent feet meet the typological criteria of the preDuchcov horizon. ${ }^{123}$ The bronze fibula from grave 345/A2. (Fig. 10.11) also belongs to the pre-Duchcov types. ${ }^{124}$ Its exact analogies are known from Nova Ves ${ }^{125}$ and Mannerdorf. ${ }^{126}$ The existence of pre-Duchcov type fibulae in Ménföcsanak is not a surprising thing nowadays, because this chronological horizon is precisely proved in the necropolis of Mannersdorf in Austrian Burgenland. ${ }^{127}$ It is important to mention, that the two fibulae were chained in grave 345/A1 (Fig. 10.1-2). Similarly, thin bronze chain connected fibulae were also found in the Mannersdorf cemetery, ${ }^{128}$ where these were documented - in a similar way to Ménföcsanak - on the neck of the skeletons. ${ }^{129}$

Two beaded-bow fibulae from tombs 362 (Fig. 11.15) and 376/B (Fig. 16.7) share the same regularly curved bow profile, small globe element, and short catch plate. In F. R. Hudson opinion the general shape of 'classical' Duchcov type derived from an earlier beaded-bow variety. ${ }^{130}$ These are early - probably pre-Duchcov ${ }^{131}$ variations of the fibulae with widely differing bow decoration but all possessing six coiled springs with internal cords, small, globular foot-elements, and similar profiles. The Duchcov or Dux type firstly identified by R. Beltz in 1911. The primary criteria of the definition were globular foot-elements and its variety. ${ }^{132}$ More than a half-century after the first publication of the treasure V. Kruta analyzed the stylistic differences between Duchcov fibulae based on the contents of female graves in Central European La Tène cemeteries. Later he defined generation time segments. ${ }^{133}$ Duchcov type fibulae were formerly found in Ménföcsanak grave nos 9, 10, and $16^{134}$ which have known close analogy from Neunkirchen. ${ }^{135}$

Disc-footed Münsingen type fibulae were found in tomb 360 (Fig. 14.5) and 379 (Fig. 17.2). The discfooted fibula was also identified by R. Beltz at first. ${ }^{136}$ Characteristics of the type are high-arching, thickened bow, short disc foot with the short catch plate, and six-coiled spring. The disc feet usually may have beaded or inlaid coral decoration but in some cases, it lost or decomposed in soil. P. Jacobsthal, in fact, highlighted a series of fibulae which he regarded as representing a Münsingen class ${ }^{137}$ however, deficiency noted by L. Pauli ${ }^{138}$ and G. Kaenel ${ }^{139}$ when dealing with relevant fibulae from Dürrnberg and Western Switzerland respectively. Within this overall class has many variations of the type. ${ }^{140} \mathrm{~A}$ valid classification of all relevant La Tène disc-footed fibulae suggested being F. R. Hodson at Münsingen-Rain cemetery, where he realized different chronological stages in changing of the fibula fashion. ${ }^{141}$ The typology of disc-footed fibulae carried out by J. Bujna in recent decades. ${ }^{142}$ On the disc foot of fibula from Ménföcsanak grave, 360 is not found inlay, only the empty hole of the rivet is observed. The closest analogies of this fibula are known from Mannersdorf ${ }^{143}$ and others found in cemeteries in Czech and Moravian territory. ${ }^{144}$ However, it should be noted that the Münsigen fibula is comparatively rare in Czechia and Moravia ${ }^{145}$ because the core area of this type can be localized in Swiss territory. ${ }^{146}$ It has to mention to the unique find in

${ }^{119}$ DulęBa 2019, 373.
${ }^{120}$ GÁTI 2009, 66. fig. 4/20.
${ }^{121}$ JEREM 1968, fig. 29, 65/2.
${ }^{122}$ About the problematics and chronological aspects of

Early La Tène period between the Pannonia and North-Balkan: PoPOVIć 1996, 105-125.

${ }^{123}$ HOLODŇÁK-WALDHAUSER 1984, Fig. 2,7-9.

${ }^{124}$ HolodŇÁK-WALdHAUSER 1984, Fig. 2,6, 2,23.

${ }^{125}$ HOLODŇÁK-WALdHAUSER 1984, Fig. 3,3.

${ }^{126}$ RAMSL 2011, Taf. 24,4.

${ }^{127}$ RAMSL 2011, 140-141.

${ }^{128}$ RAMSL 2011, Taf. 34,4, 80,5, 88,9-10, 142,4a-b.

${ }^{129}$ RAMSL 2011, 34-36, 76-77, Taf. 34,4, 142.

${ }^{130}$ Hodson 1968, 35-36.

${ }^{131}$ The beaded-bow fibulae reserved Horizon D and E (see Hodson 1968, Pl. 123) and it have identifed as pre-Duchcov type in Bohemia (see VenClová et al. 2013, 112-114).

${ }^{132}$ BELTZ 1911, 679. The well-known "Duchcov treasure" is a hoard containing several thousand bronze fibulae, torques, brace-

Acta Archaeologica Academiae Scientiarum Hungaricae 71, 2020 lets, finger rings were deposited in bronze cauldron in the territory of Obři Pramen thermal spring in Lahošt' near Duchcov (named Dux in German). BERGER 1882; KYSELA-VENCLOVÁ 2019, 133-134.

${ }^{133}$ KrUTA 1971; KrUTA 1979, 81-91.

${ }^{134}$ UzsoKi 1987, Pl. 6,2-4, 10,1, 18,4-5.

${ }^{135}$ Schiel 2015, Taf. 18, Inv.-Nr. 11202., Taf. 25, Inv.-Nr. 11240.-11241.

${ }^{136}$ BeLTZ 1911, 678,

${ }^{137}$ JACOBSTHAL 1944, 129.

${ }^{138}$ Pauli 1978, 125.

${ }^{139}$ KAENEL 1990, 239.

${ }^{140}$ Hodson 1968, 36-37.

${ }^{141}$ Hodson 1998, 34-35.

${ }^{142}$ Bujna 1998, 171-203; Bujna 2003, 52-55.

${ }^{143}$ RAMSL 2011, Taf. 126,9-10, 129,5a.

144 ČIŽMÁŘ 1995, Abb. 1, 6-9; SANKOT 1998, Abb. 1, 2-3.

145 ČIŽMÁř 1995, 69.

${ }^{146}$ KAENEL 1990, 238-239. 
Ménföcsanak grave 4, which is an especially beautiful iron fibula with inlaid coral decoration on the disc foot, and relief motif design in the Continuous Vegetal, or so-called Waldalgesheim Style ${ }^{147}$ on the bow. This is type 1B in J. Bujna's classification, which belongs to the younger phase of La Tène B1. ${ }^{148}$ Furthermore, there is one another disc-footed fibula in grave 14 excavated by A. Uzsoki in $1968 .{ }^{149}$ The closest analogies of inlaid coral decoration from the tomb 14 are known from the Swiss plateau. ${ }^{150}$ It has to mention that disc-footed bronze fibula (Bujna BF-D1-A type $)^{151}$ also found as a stray find at the Ménföcsanak settlement near the cemetery. ${ }^{152}$

Zoomorphic fibula with stylized griffin head was found in Ménföcsanak grave 345.B1. (Fig. 9.3) The foot of these fibulae is ring-shaped and ornamented with a stylized dragon or griffin head with an open wide mouth. ${ }^{153}$ This type of fibula mainly occurs in the Carpathian Basin, and the distribution is concentrated in the area of northern Transdanubia and Danube Bend, ${ }^{154}$ but it has also spread to the North-Balkan, ${ }^{155}$ Banat, and Transylvania. ${ }^{156}$ A commonly cited object is the stray find from Szentendre which is attached by a chain to a Duchcov type fibula. ${ }^{157}$ Therefore, it is proved that the zoomorphic fibula with stylized griffin head has to connect to the Duchcov horizon that is the La Tène B1 period. ${ }^{158}$ Finally, it has to shortly refer another fibula with stylized griffin head which was found in Ménföcsanak grave 888 in the excavation year 2006. ${ }^{159}$

An Early La Tène Scheme bronze fibula with wide arc bow is from Ménföcsanak grave 752 (Fig. 12.9). This is the BF-A3-C type in J. Bujna's classification. ${ }^{160}$ It has good analogy from the cemetery Gumefens-Pra Perry in Switzerland, where this type was found together with La Tène B2 variations of disc-footed, coral inlay decorated fibulae. ${ }^{161}$ Another example of it is also known from Dubnik in Southwest-Slovakia, which was dated by J. Bujna to La Tène B2 phase, as well as the BF-C1/C2 type ${ }^{162}$ bronze fibula with globular foot element, which was also found in Ménföcsanak grave no. 752 (Fig. 12.8), and the wearing of it can be stated in the same period.

The iron fibulae were usually unearthed in fragmented and strongly corroded in Ménföcsanak. This circumstance largely restricted the determination of the type, variation, and also chronological position. Such iron fibulae were found in poor condition in grave nos 301 (Fig. 3.6-7), 303 (Fig. 4.9, Fig. 5.1-2,6), 350 (Fig. 13.2), 367 (Fig. 15.4,9), 376/A (Fig. 16.1), 379 (Fig. 17.1,3), 465 (Fig. 18.1), 737 (Fig. 19.6), 760/A (Fig. 22.2), and 760/B (Fig. 22.1). However important to note, because it seems that these iron fibulae have unbounded foot, which can be referred to as its chronological positions. Traditionally the unbounded fibulae with globular foot element - like the special variations of Duchov-type - emerged in the La Tène B1 phase, ${ }^{163}$ and later, the bounded variations firstly appeared in the same grave context together with unbounded variations in La Tène B2 period. This statement applies to both of the bronze and iron fibulae. ${ }^{164}$

\section{Neck-rings}

The rings worn around the neck are usually distinguished primarily by their material (iron, bronze, silver, or rarely gold), the method of closure (e. g. hook-and-eye), and the type of decoration (incised, inlayed or plastic). According to the generally accepted view, the different neck-rings were typical of the Early La Tène period. ${ }^{165}$

\footnotetext{
${ }^{147}$ MÜLLER 1998, 81. The "Continuous Vegetal Style", also known as the "Waldalgesheim Style" is based mainly on plant motifs which are also used intricate fantastic images that depict human or animal faces, where the ornament is typically dominated by continuously moving tendrils of various types, twisting and turning in restless motion across the surface. The images sometimes can be interpreted in a variety of ways. KRUTA 1986, 7-32; KRUTA 2000, 111-118 and 429-433; Megaw-Megaw 2001.

${ }^{148}$ Bujna 1998, 182, 189, 195.

${ }^{149}$ UZSOKI 1987, 16, 23-24, Pl. 1,5, 14,1a-b.

${ }^{150}$ KRUTA 2014, 693.

${ }^{151}$ BUJNA 2003, 53.

${ }^{152}$ TANKÓ 2010a, 257, Fig. 8.

${ }^{153}$ Szabó 1974; Binding 1993, 39-40; Rustoiu 2008, 118-119; Rustolu 2012, 359.

${ }^{154}$ Litér: MárTon 1933, Taf. 5,2; Pilismarót-Basaharc: SZABÓ 1974, 72; Püspökhatvan: MÁrTON 1933, fig. 8,8; Sopron-Bécsidomb: HunYady 1944, Taf. 18,5; Szentendre: SZABÓ 1974, Fig. 1-3.
}

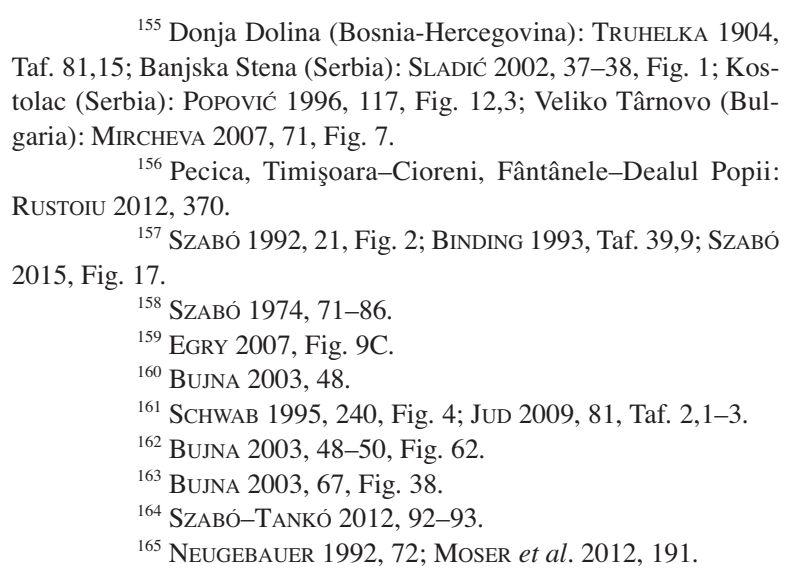

Acta Archaeologica Academiae Scientiarum Hungaricae 71, 2020 
Iron wire neck-ring with circular cross-section was worn by female deceased of the double grave 303 in Ménföcsanak (Fig. 4.4). This hoop was strongly corroded and because of this, the method of closure cannot be reconstructed. However, the textile preserved by the corrosion remained on the surface of the object. Similar to this, iron neck-rings were found in Au am Leithaberge ${ }^{166}$ and Mannersdorf. In this latter case, it is questionable that the closed ring with an inner diameter of $12 \mathrm{~cm}$ when and by what procedure was placed on the neck of the deceased. ${ }^{167}$

Bronze wire neck-ring with circular cross-section was found in grave 348. This ring is consisting of two parts and fastened its ends (Fig. 12.1). Massive bronze torques with a circular cross-section and simple hook-andeye fastening on the skeleton determined as male in Ménföcsanak grave 376.B. There was a little knob on the end of the hook (Fig. 16.4). The simple hook-and-eye fastened neck-rings are known with many examples from the Early La Tène cemeteries. The closest analogies can be mentioned the torques made of bronze from PilismarótBasaharc, ${ }^{168}$ silver from Budapest-Csepel, ${ }^{169}$ and twisted gold from Kósd. ${ }^{170}$ Similar to the latter, twisted bronze neck-ring was also found in Ménföcsanak grave 367. This twisted wire ring has two hooks at the ends (Fig. 12.1). This fastening method is also known from a grave of Petőháza. ${ }^{171} \mathrm{~A}$ similar, but hook-and-eye torques found in Ossarn bei Herzogenburg in Austria. ${ }^{172}$ Four fragments of a neck-ring made of bronze were also uncovered in Ménfócsanak grave 4. It has a hook clasp at the two ends too. ${ }^{173}$

\section{Thin bronze chains}

The thin bronze chain was found in Ménfőcsanak grave no. 303 (Fig. 4.1A-1B,10). Two bronze fibulae were connected with a thin bronze chain in the grave no. 345/A1 (Fig. 10.1-2). These chains are a serial assembly of connected pieces, called links, small wire rings were made of bronze. The occurrence of fibulae connecting with the chain is not unique in the Carpathian Basin. These chains were usually worn by females and generally found on the neck of the deceased in the graves. It has many analogies in Eastern Austria, ${ }^{174}$ Northwest Slovakia, ${ }^{175}$, and also in the middle zone of the Carpathian Basin. ${ }^{176}$ It has to emphasize that a thin bronze chain were uncovered together with an amber ring in many cases in Ludas and also Sajópetri. ${ }^{177}$ The closest analogies of it are known from the necropolis of Maňa in Southwest Slovakia. ${ }^{178}$ A similar situation could be shown at Ménfö́csanak in grave 303, where was not amber, but the bronze ring was chained on the neck of the deceased. Chronologically, it seems that the thin bronze chain was commonly worn in the La Tène B2-B2/C1 phases, ${ }^{179}$ however, the earliest examples appeared - as it proved by many graves in Pottenbrunn ${ }^{180}$ and Mannersdorf ${ }^{181}$ - in the La Tène B1 phase.

\section{Glass, amber and coral beads}

There were glass beads in three graves in Ménföcsanak. Transparent blue glass beads twisted in spiral coils, biconical large, transparent, turquoise blue glass beads (Fig. 4.8), and hyacinth blue globular and a disk-shaped also hyacinth blue glass beads (Fig. 5.4) were found in the grave 303. Small, biconical, and ring-shaped dark blue glass beads have been described by A. Uzsoki in grave 9 at Ménföcsanak. ${ }^{182}$ The closest analogies of biconical turquoise blue glass bead are known from Pottenbrunn, ${ }^{183}$ Dubník, ${ }^{184}$ Mannersdorf, ${ }^{185}$ Au am Leithaberge, ${ }^{186}$ and also Solymár ${ }^{187}$ and Dürrnberg. ${ }^{188}$

Transparent, white, amphora-shaped glass bead (Fig. 11.3) was in grave 347 in Ménföcsanak. The amphora-shaped beads were produced between the end of the $5^{\text {th }}$ century and the beginning of the $3^{\text {rd }}$ century BC. ${ }^{189}$

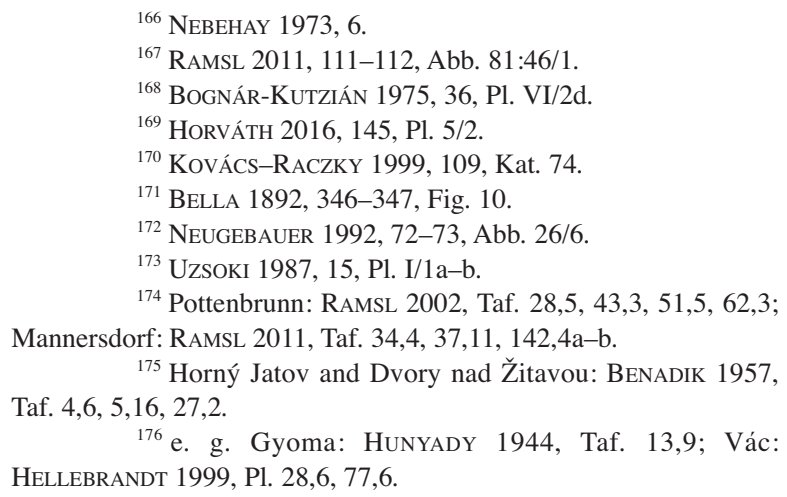

${ }^{177}$ Ludas: SZABÓ et al. 2012, Pl.1,2, 20,7; and Sajópetri: SZABÓ et al. 2018, Pl. 10,9, 16,12, 35,4, 36,2, 58,12, 59,11.

${ }^{178}$ BENADIK 1983, Taf. 45,11, 47,9, 47,13, 55,11-12.

${ }^{179}$ SZABÓ-TaNKó 2012, 103; SZABÓ-TANKó 2018, 166-167.

${ }^{180}$ RAMSL 2002, Taf. 39,6, 70,5.

${ }^{181}$ RAMSL 2011, 133-134, Taf. 27,17, 98,3, 104,1, 105,5.

${ }^{182}$ UZSOKI 1987, 34, Pl. 7,3b.

${ }^{183}$ RAMSL 2002, 63, Abb. 58, Taf. 49,4.

${ }^{184}$ Bujna 1989, Taf. 24,8a-f.

${ }^{185}$ RAMSL 2011, 131, Abb. 105.

${ }^{186}$ NeBehay 1973, Taf. 24, 2.

${ }^{187}$ Maróti-KecsKés 2008, 55, Fig. 4.

${ }^{188}$ Moser et al. 2012, 198-199.

${ }^{189}$ Meduna 1970, 231, 235; Venclová 1990, 59; Rustolu 
belong to the typologically same group differ slightly from each other in the decoration and formation of ribbing. For example, the bracelet form grave 301 (Fig. 3.4-5) cannot be integrated into the Bujna's system in all aspects. In this case, according to German terminology named "Geperlt" ${ }^{234}$ product definitely different from presented by J. Bujna. ${ }^{235}$ It seems, the nearest analogies of this bracelet are known Almásfüzitő grave 1 in Hungary ${ }^{236}$ while this was particularly commonly occurred in Austria, where similar finds were found in Pottenbrunn, ${ }^{237}$ Neunkirchen, ${ }^{238}$ Mannersdorf, ${ }^{239}$ and Dürrnberg. ${ }^{240}$ Some analogies of this type were also published from Moravia. ${ }^{241}$ The solid open ring with ribbed body and sealed ends was found in grave 307 in Ménföcsanak (Fig. 6.1) was identified by J. Bujna as variant BR-B4-Ab. ${ }^{24}$ Similar to the pieces from tomb 301, the closest analogies of the bracelet from grave 307 are known from Pottenbrunn ${ }^{243}$ and Mannersdorf. ${ }^{244}$ Some nearer examples also can be mentioned from SopronBécsidomb in West-Hungary ${ }^{245}$ and Dubník in Southwest-Slovakia. ${ }^{246}$ The bracelet form Ménföcsanak grave 379 (Fig. 17.6) can be considered a transitional type which corresponds in part to the Bujna BR-B1Aa variant, ${ }^{247}$ while the profiled endings of it rather have a relation to the bracelets with sealed ends discussed above.

A pair of simple circular cross-section bracelets with a biconical pin-and-hole fastened ending was discovered in Ménföcsanak grave no. 345/B1 (Fig. 9.6-7). The closest analogies of these rings were in grave 4 and 9 excavated by A. Uzsoki. The observable differences are that the fastening is not conical but profiled on the hoop from tomb $4,{ }^{248}$ and the findings found in tomb 9 have a rectangular cross-section. ${ }^{249}$ On the other hand, despite being similar fastened and beaded (Geperlt) bracelet appropriates the BR-B2-Bb type ${ }^{250}$ the simple solid circular cross-section wire bracelet cannot be found in J. Bujna's classification. Contrary it can be mentioned as close parallels the finds from Győr-Újszállás, Baj and Oggau ${ }^{251}$ with the proviso that cannot be known from published photos, whether they were made of solid wire or with a hollow interior.

The endings of wire bracelets form Ménföcsanak grave no. 347 were not profiled, but it has also pin-andhole fastening. The two barrel-like parts facing each other decorated by engraved lines (Fig. 11.6-7). A similarly fastened bracelet is the BR-L3-B type in J. Bujna's system ${ }^{252}$ which has only one representative analogy known from Maňa. ${ }^{253}$

The hollow bracelets and anklets made of iron or bronze sheet form an independent group beside the solid wire rings in Ménföcsanak. Two hollow bronze anklets were in grave nő. 379 (Fig. 17.7-8). One of these was decorated with engraved geometric motifs. Triangular fields at the ends framed by a double line and filled with hatches and several point-circles are at the apex of the triangle (Fig. 17.8). This is a special composition that also occurred in Mannersdorf ${ }^{254}$ and Dürnberg ${ }^{255}$ cemeteries. The other hollow bronze anklet from grave 379 was undecorated and fastened by a rivet at the end (Fig. 17.7). This method of fastening is also discernible in the case of another hollow bronze anklet in grave no. 347 (Fig. 11.8), and has some analogies in Almásfüzitö ${ }^{256}$ and Mannersdorf. ${ }^{257}$

The iron rings from grave nos 340 (Fig. 6.4), 350/A (Fig. 13.5) and 754 (Fig. 19.2) were strongly corroded, therefore, we refrained from their typological definition.

14 fingerings and small rings were found in 35 graves in Ménföcsanak. In some cases, more than one small rings were in the same grave. For example, five pieces were in the grave no. 376/A (Fig. 16.6 8,11-12) and four different were in the grave no. 303 (Fig. 4.5-6,13-14). However, there was only one-pieces in the grave nos 307

${ }^{234}$ RAMSL 2002, 61.

${ }^{235}$ Bujna 2005, 19, Fig. 8.

${ }^{236}$ VADÁSZ 1987, 238, Pl. IX,1-2.

${ }^{237}$ Neugebauer 1992, Abb. 23, 8-19; RAmsL 2002, 61-63, Taf. 41,6-9, 62,8.

${ }^{238}$ SCHIEL 2015, Taf. 22. Inv.-Nr. 11221

${ }^{239}$ RAMSL 2011, Taf. 40.4,7, 106.2a-b.

${ }^{240}$ Penninger 1972, Taf. 33A, 10; TiefengraberWiLTSCHKE-SCHROTTA 2012, 75, Grab 37/6.

${ }^{241}$ ČIŽMáŘová 2011, Tab. 2.4, 3.1.

${ }^{242}$ Bujna 2005, 25-26.

${ }^{243}$ RAMSL 2002, 61-62, Taf. 35,4.

${ }^{244}$ RAMSL 2011, Taf. 27,11-12, 162,5.

${ }^{245}$ HunYady 1944, Taf. 27,6.

${ }^{246}$ Bujna 1989, Taf. 33,4

${ }^{247}$ Bujna 2005, 19-21.
${ }^{248}$ UZSOKI 1987, P1. 2,2.

${ }^{249}$ UZSOKI 1987, Pl. 8,3-5.

${ }^{250}$ Bujna 2005, 21-24. The only mentioned example is from Dubník: Bujna 1989, Taf. 4,9.

${ }^{251}$ HunYady 1944, Taf. 27,1-3.

${ }^{252}$ BujNa 2005, 86-87.

${ }^{253}$ BENADIK 1983, Taf. 8,8

${ }^{254}$ Neugebauer 1992, Abb. 20; RAMSL 2011, Fig. 84, 101, Taf. 43,19a, 51,1b-2b, 55,9a, 56,8a, 174.

${ }^{255}$ Moser et al. 2012, 97, grave 213/2-3, 149, grave 219/4-5; TiEFENGRABER-WiLTSCHKE-SCHROTTA 2012, 30, grave 16/45,51 , grave $20 / 3-4,61$, grave $28 / 16-17,75$, grave $37 / 11,132$, grave 65/3-4; Tiefengraber-WiltschKe-Schrotta 2015a, 93, grave 240/7-8.

\footnotetext{
${ }^{256}$ VADÁSZ 1987, Pl. 8,1-2.

${ }^{257}$ RAMSL 2011, Abb. 84, 101-102.
} 
(Fig. 6.3), 379 (Fig. 17.4), 744 (Fig. 20.3), 752 (Fig. 12.10) and 760 (Fig. 23.3). Most of the fingerings and small rings were made of bronze, but only the pieces from no. 303 (Fig. 4.14) and no. 752 (Fig. 12.10) were made of iron. It is important to note here that the rings which were found beside the scabbard of a sword cannot be classified as wear items. These most likely were components for suspending the weapon (Fig. 13.4 in grave no. 350/A; in grave no. 755; Fig. 21.3 and Fig. 22.3 in grave no. 760/B). ${ }^{258}$

The fingerings and small rings are closed and have a simple circle, oval or rectangular cross-section in the largest number in Ménföcsanak (Fig. 4.6, Fig. 12.10, Fig. 16.8, Fig. 16.11, Fig. 17.4, Fig. 20.3). A similar image unfolded before us in recently published Ludas $^{259}$ and Sajópetri necropoleis, where was inferred the general habit of wearing objects while typologically only minimal differences could be detected. ${ }^{260}$

The bronze plate closed ring from grave no. 307 has a simple design (Fig. 6.3) which was identified as J. Bujna's BR-K2-3 type with some analogies from Southwest Slovakiaa ${ }^{261}$ and Pottenbrunn from Austria. ${ }^{262}$

The open bronze fingering with stacking ends and oval cross-section from Ménföcsanak grave no. 376/A (Fig. 16.6) is slightly different from the above-mentioned examples. It has analogies in Ludas ${ }^{263}$ and other cemeteries in the Carpathian Basin. ${ }^{264}$ The closed bronze ring with the sealed design was found at the neck of the deceased in grave no. 303 (Fig. 4.5). It is questionable in this situation whether it was a fingering or a pendant functionally. A similar type of ring is known from the cemetery in Les Jogasses in France. ${ }^{265}$ Here we have to mention the closed bronze ring with also sealed design from grave 760 in Ménfőcsanak (Fig. 23.3).

\section{Belts and buckles}

The Ménfócsanak graves yielded five buckles with rectangular belt-plaques made of iron. (grave no. 303: Fig. 4.15; grave no. 307: Fig. 6.12; grave no. 345/A1: Fig. 10.6; grave no. 345/B1: Fig. 9.4; grave no. 379: Fig. 17.5). The other three pieces were formerly published by A. Uzsoki from this cemetery. ${ }^{266}$ It seems, that there are significant differences in the size of the rectangular iron plaque which is fastened to the hook by massive rivet. In other words, larger and smaller plates also occur among them. So in terms of size, there is a large from grave no. 303 (Fig. 4.15), two middle-sized from grave no. 307. and no. 345/B1 (Fig. 6.12, Fig. 9.4) and also two pieces from grave nos 379 and 345/A1 (Fig. 10.6; Fig. 17.5). According to the construction, we can assume that iron plate was fixed to a belt made of organic material, probably leather. It can be established empirically that the dimensions of belt mainly could be $4-6 \mathrm{~mm}$ thick and $25-35 \mathrm{~mm}$ wide. ${ }^{267}$ In other respects, it was also be observed that these buckles typically belonged to women's wear in Ménföcsanak.

It can be stated on the basis of the general examination of buckles with rectangular belt-plaques (in German term kästchenförmige Beschläg) made of bronze and iron that it was mainly produced together with the openwork buckle ${ }^{268}$ in the Eastern Alpine territory in the Early La Tène Period. ${ }^{269}$ On the other hand, these finds are remarkable and one of the earliest examples of the 'Celtisation' as the typical product of La Tène culture in the Eastern Alps region and the Carpathian Basin. ${ }^{270}$ However, it must refer to that these artifacts are traditionally connected by some researchers to the La Tène A phase, ${ }^{271}$ but it was found also in the context of La Tène B1-B2 phases. ${ }^{272}$ It has also been suggested that there are differences in the size of hooks, that is, the buckles made with shorter hook seems older. $^{273}$ This statement was also confirmed by Ludas example, where a buckle made of iron was found with long hook and small plate in a La Tène B2 grave. ${ }^{274}$ The buckles in Ménföcsanak were produced with a short hook without exception, so these can be early types. The closest analogy to this was found Inzersdorf, ${ }^{275}$ Pottenbrunn, ${ }^{276}$ Kuffern, ${ }^{277}$ Au am Leithagebirge, ${ }^{278}$ and Bučany. ${ }^{279}$

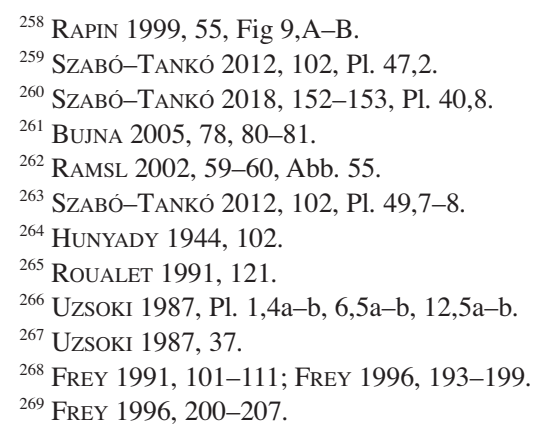

${ }^{270}$ For example in Bučany: BuJNA-ROMSAUER 1983, 299

${ }^{271}$ GugGisberG-STÖLlner 1996, 122.

${ }^{272}$ Dürrnberg: Moser et al. 2012, 182-183; Pottenbrun: RAMSL 2002, 58 .

${ }^{273}$ RAMSL 2002, 58

${ }^{274}$ SZABÓ-TANKÓ 2012, Pl. 27,7; about the chronological position: fig. 187.

${ }^{275}$ Neugebauer 1996, Taf. 14,3, 19,5.

${ }^{276}$ RAMSL 2002, Abb. 54; Taf. 26,3, 27,6, 29,6.

${ }^{277}$ Nebehay 1993, Taf. 15,3.

${ }^{278}$ NEBEHAY 1973, Taf 2,5.

${ }^{279}$ Bujna-Romsauer 1983, Pl. 5,1a-b, 6,9, 7,3, and 8,5. 


\section{Knife}

Three examples of slashing knife (also called hewing or cutting knife as well as Hiebmesser in German term) were published by A. Uzsoki from Ménföcsanak formerly. ${ }^{280}$ It is surprising in light of this, that only a corroded fragment of the iron blade was found from 35 burials in the recently investigated part of the cemetery (Fig. 190.4). This blade is so corroded and fragmented that it is impossible to class typologically.

\section{Weapons}

It seems from the analysis of graves in the Carpathian Basin that members of the Celtic elite considered themselves mainly as warriors in the period of the Great Historical Migration to Balkan expansion of the Celts $\left(4^{\text {th }}\right.$ and $3^{\text {rd }}$ century BC) ${ }^{281}$ There are seven warrior graves in the recently excavated part of the Ménföcsanak necropolis. In other words, only $20 \%$ of the 35 persons buried in the cemetery were armed. This corresponds to the $15-25 \%$ commonly typical rate of the Carpathian Basin, ${ }^{282}$ even if in the present case we can only talk about a specific detail of the Ménföcsanak cemetery. Spearhead was found in grave no. 303 and lance in the grave no. 760 (Fig. 5.13; Fig. 23.1). Five warriors equipped by sword and spearhead or lance were laid in grave nos 343/B, 350/A, 744, 755, and $760 / \mathrm{B}$.

\section{Swords and scabbards}

Five iron swords (Fig. 27) were found in this part of Ménföcsanak cemetery. ${ }^{283}$ The swords were complete and placed in the scabbard in all situations. These were unbent, i.e., there was not deliberately caused deformation and the bending of swords was not part of the burial rite. Both of the swords and the scabbards were heavily corroded. As a result of rust, the iron sheets of scabbards have generally remained in a rather poor or even fragmented condition. Therefore, there was no possibility to observe traces of engraved decoration on the surface of scabbards. Some of the swords were analyzed by X-ray and microscope, however, these methods did not lead to evaluable results. Unfortunately, engraved decorations were not discovered on surfaces of the iron plate of scabbards in Ménföcsanak. The chape as a protective fitting at the bottom of a scabbard was mostly fragmented or just recognizable in corrosion due to poor conditions. Thus the types of chapes were not or only uncertainly definable (grave no. 343/B: Fig. 7.4b; grave no. 744: Fig. 20.6c; grave no. 755: Fig. 21.4b; grave no. 760/B: Fig. 21.5b). The only exception was the chape of the scabbard from grave no. 350/A (Fig. 13.8c), which was also strongly corroded but it can be certainly identified as Kósd D type. ${ }^{284}$ This type was named after the characteristic form of chape of the sword scabbard was found in Kósd grave 15, and also grave nos 2 and $10{ }^{285}$ There are some analogies in a Ruma-Borkovac, ${ }^{286}$ Beograd-Karaburma, ${ }^{287}$ and Rezi-Rezicseri. ${ }^{288}$ It probably can be classified here as a fragmentary example from Pottenbrunn. ${ }^{289}$ The occurrence of known some finds is mainly localized in the Middle Danube Region. ${ }^{290}$ A recent find was also found Monte Bibele in Italy ${ }^{291}$ and Cetina near Trilj in Croatian Dalmatia. ${ }^{292}$ However, the latter is a less typical example and rather forms a transition to the Hatvan-Boldog type swords.

\section{Shields}

Clear evidence of shield use has rarely been found in this part of Ménföcsanak cemetery. Iron umbo was not found. The presence of shields made primarily of organic material could only be inferred from a few minor iron parts in the funeral rite. Edge ironing was found in warrior grave no. 350/A (Fig. 13.9a-b) and perhaps the wrought iron nail reinforced also a shield too (Fig. 13.6). Probably, the massive iron nails from grave no. 760/B should also be considered as parts of a shield (Fig. 22.4). The small number of parts is not surprising if we are considering that the shield published and reconstructed by A. Uzsoki in 1970 consisted only of small iron components, like edge

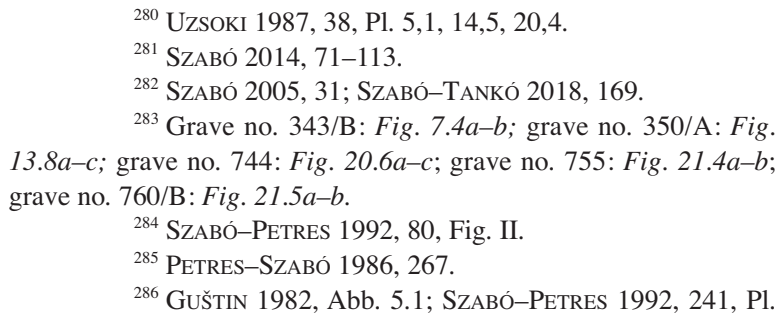

Pl. 57.

${ }^{287}$ BLeČIĆ KAVUR-KAVUR 2010, 71.

${ }^{288}$ Horváth 1987, Pl. XVII,5; SZABÓ-Petres 1992, 175,

${ }^{289}$ RAMSL 2002, 78-79, Abb. 74, 80.

${ }^{290}$ RAMSL 2003, 256, Fig. 12.

${ }^{291}$ Lejars 2008, 213; BleČIĆ Kavur-Kavur 2014, Fig.

29.3.3.

${ }^{292}$ BleČIĆ KAVUR-KavUR 2014, 266, Fig. 29.2.

123.1. 
ironings, wrought iron nails, and iron reinforcements. ${ }^{293}$ These and the organic remains of the oval shield covered the skeleton. ${ }^{294} \mathrm{~A}$ similar situation of the position of iron and preserved organic remains of the shield was documented in Velká Maňa and also Palárikovo in Southwest Slovakia where the elements of the shield also covered human body during the overall reconstruction of the warrior grave. ${ }^{295} \mathrm{In}$ light of this, the suggestion seems logical that the edge ironing from grave no. 350/A. (Fig. 13.9b) and the iron nails form the same grave and the grave no. 760/B (Fig. 13.6; Fig. 22.4) were parts of shields. Perhaps, the iron reinforcement (Fig. 5.7) found beside spearhead was also an iron component of a shield in grave 303. Fragments of edge ironing were also found in grave no. 465 (Fig. 18.3-6), however, another weapon was not discovered in this grave.

\section{Spearheads and lances}

Spearhead or lance was found in seven graves in the recently investigated part of Ménföcsanak cemetery. Lance, shield, and sword were found in grave no. 350/A (Fig. 13.3,6,8a-c,9a-b), lance or spear and sword equipped warrior was in grave no. 343/B (Fig. 70.2,4a-b), no. 744 (Fig. 20.1,6a-c), no. 755 (Fig. 21.1,4a-b) and 7 no. 60/B (Fig. 21.3,5a-b), furthermore lance was in grave no. 303 (Fig. 5.13) and no. 760 (Fig. 23.1).

Because of their versatility, high effectiveness, easy to use a simple form, and cheap cost, polearms led to many variants and were the most frequently used weapons of the Celts on the battlefield. The typology of these pole weapon is based on the characteristical form and size of the leaf. ${ }^{296}$ Polearms can be divided into two main categories. One part of these designed for extended reach and thrusting tactics such as pike or phalanx combat or against the cavalry attack. These are usually too long, heavy, and slow to be effective against opponents in a melee - assuming the lance survived intact in the first initial impact of the combat. Another group is the light throwing spear or javelin. Essentially, we can deduce the function by considering these criteria. The long and heavy lances were used extended reach and thrusting tactics, and less in hand-to-hand combat, while the light spears were suitable for throwing and close combat too. ${ }^{297}$ It has to be mentioned that the classification based on formal criteria developed for sanctuary finds in Gournay in France ${ }^{298}$ is not directly applicable to the finds of the Eastern Celts in the Carpathian Basin. ${ }^{299}$ On the other hand, the polearms cannot be determined chronologically on the basis of formal criteria. ${ }^{300}$

\section{Pottery}

73 pottery were found in 26 graves in Ménfőcsanak. There were significant differences in the number of backed clayware in burial rite. One vessel was in eight graves, two were in five graves, three in four graves, and four in three, five in five, and six different vessels were unearthed in grave no. 379. On the other hand, only one vessel was in one-third of the burials, while 2-6 ceramics were in most of the graves. Only in the grave nos 340, 362, and 752 has not been found pottery in Ménföcsanak.

The analysis of the position of the vessels within the graves is primarily based on the undisturbed skeletal burials. It is conspicuous that the ceramics were mostly deposited around the deceased's foot. Less frequently, they were placed on the lower or upper leg, possibly next to the hip region. Any deviation from this generally considered habit is observed in only a few cases. A vessel was placed next to the human skull in the grave 379 , while another was discovered on the chest of deceased in grave no. 343/B. A vessel was in the left arm of one of the skeletons in the double grave no. 303. It can also be considered different from the general burial habit, that all of the five ceramics were deposited in one group next to the left hand of the deceased in grave no. 342 (Fig. 28). The position of vessels is correlated with the deposited situation of animal remains in graves in many cases (Fig. 29). This is understandable because food or drink was also placed in the pots next to the dead. ${ }^{301}$ Meat dishes could still be put in wooden jars, but it is also possible that they were packaged in textiles. However, the organic matter has been destroyed, so even without a vessel, meat remains can be found in the graves. In the cemetery of Ménföcsanak, there were animal bones in 11 inhumation graves, referring to the custom of giving food attachments and the funeral feast associated with the funeral ceremony. The custom is typical of both the graves with ditches and the simple graves.

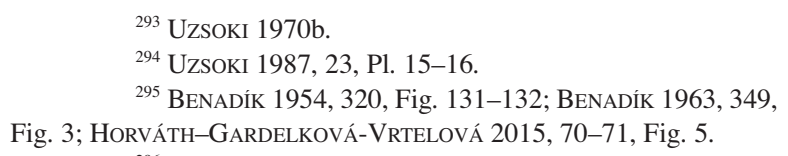

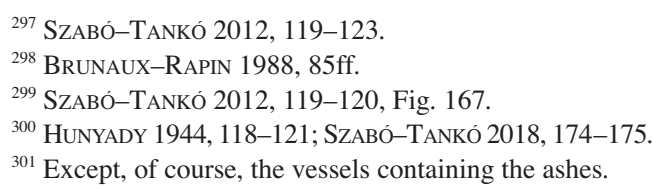


It occurs in the graves of both adults and children too. With the exception of one case (350/A), edible and good quality animal parts are found next to the dead.

The 73 vessels were largely discovered intact and only a smaller part was fragmented or destroyed by the pressure, humidity, and chemical processes of soil during the more than two thousand years. In other words, most of the ceramic finds have come to light in good condition, which resulted from the particularly advantageous properties of the soil. Only eight ceramic vessels (only $11 \%$ ) were totally destroyed and unable to make the conservation process with them. Compared to recently studied cemeteries this is a significantly better ratio than, for example, was observed in Ludas where the ceramic material was particularly poorly retained. ${ }^{302}$ However, this lags behind Sajópetri, where ceramic finds have generally remained in better condition. ${ }^{303}$ It seems likely that, this discrepancy was not primarily due to the quality of the pottery, but rather to the different soil and hydrological conditions of the sites.

The classification of burial ceramics in Ménföcsanak is primarily based on the examination of technological and formal features. For this, we have taken into account the recent research of La Tène ceramology. The recently published monograph of the Celtic settlement of Sajópetri is a significant step forward in terms of Late Iron Age ceramic typology. ${ }^{304}$ The technological and typological system developed there also serves as a starting point in the present work. ${ }^{305}$

Considering the technology of production for the first time, it can be stated that the proportion of wheelthrown ware was outstanding in Ménföcsanak. Of the 65 vessels that can be analyzed 63 were wheel-thrown made, while only two were certainly produced by hand made (Fig. 12.11 and Fig. 18.11). So 97\% of the burial ceramics were wheel-thrown ware. Based on surface examinations, differences were observed in the quality of producing. In four cases, it could not be clearly decided whether it was hand-built and then throwed or whether it was formed by throwing on a slow wheel (e.g.: Fig. 8.2,5-6, Fig. 12.7).

The bowl with S-profile (type II.1.1.) occurred in the largest number (17 pcs) in the classification typologically in Ménföcsanak. (Fig. 2.5, Fig. 3.12, Fig. 5.11, Fig. 8.1, Fig. 10.5, Fig. 11.11-12, Fig. 12.5-6, Fig. 13.11, Fig. 14.3, Fig. 16.3, Fig. 17.13, Fig. 18.7,15, Fig. 19.8,11). These bowls were usually undecorated (Fig. 12.5, Fig. 17.13, Fig. 19.8), except for the rib (Fig. 2.5, Fig. 3.1., Fig. 5.11, Fig. 10.5, Fig. 11.12, Fig. 12.6, Fig. 13.11, Fig. 14.3, Fig. 16.3) or the single (Fig. 18.7,15) and double trench running around horizontally on the shoulder of the vessel (Fig. 8.1., Fig. 11.11, Fig. 19.11). The smoothed bands and wavy lines combined decoration in the inner part of the bowl (Fig. 19.11) was a unique and special find, which has analogies in the excavated part of the cemetery published by A. Uzsoki formerly ${ }^{306}$ This unique wavy line decoration is particularly interesting because it is similar on the shoulder of the pot found in Dürnberg grave $15,{ }^{307}$ on the shoulder of the clay chalk belonging to grave $50,{ }^{308}$ and on the shoulder of the S-profile bowl of grave $53 .{ }^{309}$ These findings may suggest a strong relationship between the two sites, for which further research is needed in the future.

Pots (type II.3) occurred graves frequently. 14 of them were found in Ménföcsanak (Fig. 2.4, Fig. 3.14, Fig. 5.12, Fig. 8.3-4, Fig. 10.8, Fig. 11.14, Fig. 13.10, Fig. 14.2, Fig. 17.12, Fig. 18.9, Fig. 19.10, Fig. 20.5, Fig. 21.6). The rib, rib with double trenches, and only trench running around horizontally on the neck and/or shoulder of a vessel are considered common in this type. These decorations can be observed on $90 \%$ of the pots.

Small pots (type II.5) were only found in two graves. There is rib running around horizontally on the neck of both vessels (Fig. 3.12; Fig. 15.10).

A large number of the flask (type II.8) of different sizes and shapes is remarkable in Ménföcsanak. Within this, the lens-shaped bottle, so-called Linsenflasche form a separate group, which has many examples been found in this cemetery (Fig. 2.3, Fig. 3.11, Fig. 5.10, Fig. 14.8, Fig. 19.12, Fig. 23.1, Linsenflasche: Fig. 6.7, Fig. 15.11, Fig. 17.10). This type required briefly to discuss here. As early as 1944, I. Hunyady attempted to develop a classification for the lens-shaped bottle and to determine its chronological boundaries. In her opinion the Linsenflasche was one of the characteristics find of "LT A Ostgruppe", however, it occurred in the northwest part of Hungary in the La Tène B phase and spread to the east of Danube and south of Balaton in La Tène C phase. ${ }^{310} \mathrm{~T}$. Voigt analyzed

\footnotetext{
${ }^{302}$ SZABÓ-TANKÓ 2012, 131.

${ }^{303}$ SZABÓ-TANKÓ 2018, 197.

304 SZABÓ 2007.

${ }^{305}$ SzABÓ et al. 2007, 229-252.

${ }^{306}$ UzSOKI 1987, Pl. 19,1, 20,1.

${ }^{307}$ PenNinger 1972, Taf. 14,25.
}

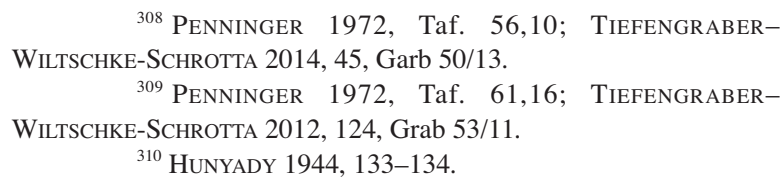

${ }^{308}$ Penninger 1972, Taf. 56,10; TiefengraberWILTSCHKE-SCHROTTA 2014, 45, Garb 50/13.

${ }^{309}$ Penninger 1972, Taf. 61,16; TiefengraberWILTSCHKE-SCHROTTA 2012, 124, Grab 53/11.

${ }^{310}$ HUNYADY $1944,133-134$. 
it from a completely different perspective in 1969. He summed up everything he could have known until then. There are rib, rib with double trenches, and only trench running around horizontally on the neck and/or shoulder of lensshaped bottles. T. Voigt believed that the decoration or non-decoration of the vessels is an essential classification criterion. Based on this, he defined the pieces decorated with stamped motifs as type 'A' and the unadorned ones as type ' $\mathrm{B}$ '. He found that the decorated pieces were specific for the La Tène A phase, while the bottles without decoration were more typical for the La Tène B phase. ${ }^{311}$ Today, this theory is almost unacceptable.

Later, F. Schwappach discussed this type as a representative form of Eastern La Tène pottery. He believed that lentil-shaped bottles could be traced back to the local pottery tradition of Hallstatt culture in the CzechMoravian region. On the other hand, the typical Linsenflasche is already particularly relevant to the earliest phase of La Tène culture. F. Schwappach's significant recognition was the formal development that can be detected and defined over time within the type. The point is that the height and maximum width can usually be the same as the earliest bottles. However, over time, the neck of the bottles was extremely elongated especially during the La Tène B phase to which a relatively low, rounded, or biconic rather than the lenticular body was paired in the La Tène C phase. ${ }^{312}$ Based on several well-dated graves finds, L. Pauli found that the lens-shaped bottles are known mainly from phases A and B of the Dürnberg cemetery. Moreover, L. Pauli confirmed F. Schwappach's ascertainments based on the analysis of the necropolis. He also pointed out that, although the motifs made with the various techniques on the sides of the bottles had chronological significance, however, the typology outlined by T. Voigt was not sufficiently substantiated. ${ }^{313}$ It is important to point out that this type can also be found in the settlement belonging to the cemetery in Ménfócsanak. ${ }^{314}$ Many Linsenflasche are also known from Northwest Hungary and Southwest Slovakia. $^{315}$

The vessel from grave no. 744 deserves special attention. It has stamped triskeles consisting of connected $\mathrm{S}$-motifs running around continuous horizontally on the shoulder of the vessel. The similar continuous decoration is visible on the surface of one of the burial ceramic from Wien-Leopoldau. ${ }^{316}$ Different compositions consisting of a stamped S-motif can often be observed on ceramic finds from the Early La Tène period. ${ }^{317}$ There are also some ceramic fragments stamped with continuous S-motif among the finds of settlement in Ménfőcsanak. ${ }^{318}$

It is important to highlight that a large number of stamped pottery was found, mainly in the Early La Tène sites in Eastern Austria and Western Hungary. ${ }^{319}$ This phenomenon has been noticed by the researcher of La Tène ceramology before. Based on the Sopron-Bécsidomb, F. Schwappach dealt with the spread of the stamped S-motif and the double-lyra compositions in this region. ${ }^{320}$ E. Jerem identified convincingly a production circle of pottery based on a horizontal stamped S-motif on the vessels of Sopron, Hidegség, Pöttsching, and Mannersdorf. ${ }^{321}$ Today, it seems that extending radii of several pottery workshops can also be identified in the region of Eastern Austria and Western Hungary and these are mainly related to La Tène A and B phases. ${ }^{322}$

\section{CONSEQUENCES}

The relative chronology of Ménföcsanak cemetery is mostly based on female graves, which contain a board assortment of chronologically sensitive jewelry, wearing elements, and dress accessories. Most of all, the fibulae can help us to provide the chronological determination, because - as we could have seen in F. R. Hodson's system

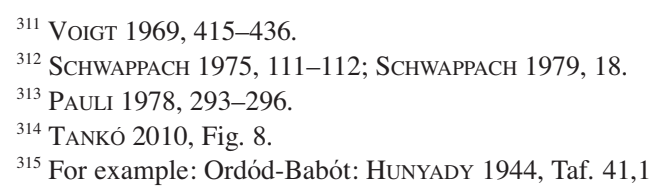
Beled: Hunyady 1944, Taf. 38,3; Hunyady 1957, 1-2; Au am Leithagebirge: HunYady 1944, 133; NEBEHAY 1973, Taf. 3,3, 17,2, 18,1; SchWAPPaCH 1979, Abb. 31; Schwandorf: HunYADY 1944, 133. Sopron-Bécsidomb: HunYADY 1944, Taf. 41,2; Győr-Kálvária: Hunyady 1944, Taf. 41,5; Bakonygyepes: HunYady 1944, Taf. 41,8; Petronell-Carnuntum: HunYADY 1944, 133; Bajč-Vlkanovo, Vel'ka Maňa: BeNADík 1962, 349, Fig. 3.

${ }^{316}$ Nebehay 1973, Taf 21, Garb 7/1.

${ }^{317}$ JEREM 1976, 45-47, Taf. 14,4
318 TANKÓ 2005, Pl. 12,9.

${ }^{319}$ E.g. Franzhausen (Neugebauer 1996, Abb. 11,9), Balf (VÁlYi 1983, 101-102., Pl. 4,2), Kloster-Weltenburg (KAPPEL 1969, Abb. 18,14), Dürrnberg-Ramsaukopf (Hell 1936, Abb. 5,2.), Dürrnberg bei Hallein (Penninger 1972, Taf. 64,10; Moosleitner-PauliPenNinger 1974, Taf. 135,24), Zemlingi (Fundberichte aus Österreich 14/1975, Abb. 209), Sankt Margarethen (Fundberichte aus Österreich 15/1976, Abb. 182) Stupava (MÁRTON 1934, Taf. 28,5) Cserszegtomaj (HunYAdy 1944,Taf. 77,1) Guntramsdorf (URBAN 1985, Abb. 28,5).

${ }^{320}$ SCHWAPPACH 1971, 142-172.

${ }^{321}$ JEREM 1984, 57-80.

${ }^{322}$ SCHWAPPACH 1971, 160; TANKó 2016, 168-170.

${ }^{323}$ Hodson 1968, 34. 
at Münsingen - it provides the greatest potential source of 'horizon-markers' ${ }^{323}$ However, fibula could not found in thirteen graves ${ }^{324}$ and iron fibulae were destroyed by corrosion in two cases. ${ }^{325}$ It also has to mention that many fibulae are typologically undeterminable due to fragmentation. ${ }^{326}$ The current overall accepted fibula classification and the other typology of wearing elements have led to the creation of at least four hypothetical chronological horizons in Ménfőcsanak.

The earliest find of Ménföcsanak cemetery is represented by the fibula with a bird's head in the grave no. 345/B1 (Fig. 9.1). The fibulae with bird's head are traditionally dated to the La Tène A period in the Eastern Alpine area. ${ }^{327}$ However, there was another zoomorphic fibula with a stylized griffin head (Fig. 9.3) found in the context of grave no. 345/B1. Another fibula with a bird's head was in grave no. 367 (Fig. 15.2) together with two iron fibulae, which are typologically undetermined due to fragmentation, but some main features of them suggest dating to La Tène B1 period. ${ }^{328}$ This and the zoomorphic fibula with stylized griffin head in context with early type bird head fibula from grave no. 345/B1 suggests to us that there were only some sporadic finds from La Tène A period, however, it is undoubtedly detected a sure La Tène A chronological horizon in Ménfócsanak cemetery.

The next detected horizon is the La Tène B1a phase which also called pre-Duchcov horizon. This is specified by characteristic fibulae (Fig. 10.2, and Fig. 10.11), which generally have a saddle-shaped and parabolic bow, but each of them is unique and there is no evidence of their serial production. ${ }^{329}$ Plain bar bronze bracelets (Fig. 10.3-4) were also commonly used on this horizon. ${ }^{330}$ These characteristic artifacts are also found in nos 345/A1 and 345/A2 burials in Ménföcsanak. However, it has to mention that a Duchcov-type fibula was connected to pre-Duchcov fibula with a thin bronze chain in the 345/A1 burial Fig. 10.1-2). This fact refers to the coexistence of these fibulae in the La Tène B1b phase.

The next is La Tène B 1b, or also called the Duchcov-Münsingen horizon, which is mainly represented by globular foot-elements decorated Duchcov-type and disc-footed Münsingen-type fibulae. ${ }^{331}$ These Duchcov-type fibulae were found in grave nos 362 and 376/B (Fig. 11.15, Fig. 16.7), while Münsingen-type were in grave nos 360 and 379 (Fig. 14.5, Fig. 16.2). The other wearing elements, for example, the torques are mainly with sealshaped ends, the bracelets have also seal-shaped ends frequently and the bodies of rings are mostly plain or grooved. Anklets are with fine ribs and the finger rings made form thin wire or wide band. Characterizing the nature of the costume are symmetrically worn bracelets and anklets with a combination of fibulae same size that fastened dresses at the chest and shoulder. ${ }^{332}$ The distribution of these artifacts was presumably a consequence of the historical migration of the Celts. Based on an examination of the earliest burials, immigration of a western originated group can be assumed in Ménföcsanak cemetery in the early $4^{\text {th }}$ century BC. ${ }^{333}$

This community was settled in the vicinity of Ménfőcsanak ${ }^{334}$ and buried onward in this necropolis. La Tène B1c phase is characterized by the later variants of Duchcov and Münsingen type fibulae in the grave contexts (Fig. 12.8-9). These have relief decoration in many cases. The costume is represented by a new combination of fibulae, where one large fibula is accompanied with two substantially smaller, mostly bronze fibulae. The inner capacity of the small bronze fibulae radically reduced to 10-20 $\mathrm{mm}$, what is indicating the changing of fashion and wearing new type dresses made of finer textiles. On the other view, this is the first horizon when the so-called "plastic style" appeared. ${ }^{335}$

LT B2a is characterized by fibulae with large globular foot and short drum-shaped bow. This type of fibulae was found in grave nos 737 and 754 in the cemetery (Fig. 19.1, 5).

Based on the history of fibulae, it seems that the spectrum of dateable finds extended from the La Tène A to the La Tène B2 phase, however, the establishment of the Ménföcsanak cemetery was not earlier than La Tène B1

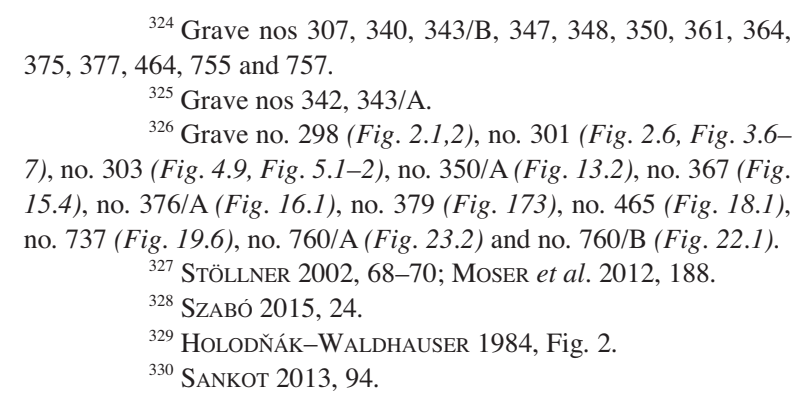

${ }^{331}$ KRUTA 1971; KRUTA 1979, 81-91; HodSON 1968, 3637; SZABó 1992, 22; Hodson 1998, 34-35; Bujna 1998, 171-203; BUJNA 2003, 52-55; SZABÓ 2015, 21.

${ }^{332}$ BUJNA 2005; SANKOT 2013, 94.

${ }^{333}$ SZABÓ 2015, 21.

${ }^{334}$ TANKÓ 2004, 105-112; TANKÓ 2005; TANKÓ-EGRY 2009, 401-416; TANKÓ 2010, 249-260.

${ }^{335}$ SANKOT 2013, 94. 
phase - according to our current knowledge and including the tombs were published by A. Uzsoki. ${ }^{336}$ It means that the earliest finds can be dated to the second half of $5^{\text {th }}$ century BC, however, the first graves were inhumed in Ménföcsanak in the beginnings of the $4^{\text {th }}$ century. The excavated youngest tombs were cremated and it perhaps buried in the first half of $3^{\text {rd }}$ century $\mathrm{BC}$, so the necropolis was abandoned in this or a later time. It has to notice that the Ménfócsanak cemetery is not unearthed and the excavated parts of it are not completely published yet. The burials probably continued in the recently excavated part of the site between 1997 and 2006. After a short report, we can only know that the more than two hundred graves were mostly cremated and they are perhaps later than burials is studied here and were published by A. Uzsoki before. ${ }^{337}$

On the other hand, it still makes sense to connect the community buried in Ménföcsanak to the so-called Celtic Historical Migration event. ${ }^{338}$ This horizon is also discoverable in the cemeteries in Pottenbrunn and Mannersdorf in Austria, ${ }^{339}$ as well as Beled, Ordod-Babót, and Sopron-Bécsidomb in West Hungary. ${ }^{340}$ The Celtic occupation and the establishment of first settlements can be done for this period in the vicinity of Györ, which is proved by the graves Győr-Kálvária, and Győr-Újszállás too. ${ }^{341}$

Finally, it has to mention shortly that a Celtic rural settlement was investigated next to the here studied cemetery. There was an Early Iron Age settlement of Hallstatt culture in the Ha C-D phases in the $6^{\text {th }}-5^{\text {th }}$ century $\mathrm{BC}$ before the occupation of the Celts. It has a later phase which was defined as Ha D/LT A transition period and characterized by some new elements of 'Celtization' in the second half of the $5^{\text {th }}$ century. ${ }^{342}$ The Celts established a village little west to the Early Iron Age settlement in the LT B phase in $4^{\text {th }}$ century BC. This rural settlement lived continuously from the Early to the Middles La Tène period and it was abandoned in the LT C phase approximately in the first half of $2^{\text {nd }}$ century BC. ${ }^{343}$ The graves published from the cemetery until now partly correspond in time with the settlement excavated in the vicinity of Ménföcsanak. This is also important because we can analyze a Late Iron Age cemetery and a settlement from many aspects together. In the case of Sajópetri, this possibility was already given in eastern Hungary, ${ }^{344}$ however, it is the first time in Hungarian Transdanubia, which we can do in the future. All in all, Ménfócsanak is one of the most significant Late Iron Age archaeological sites in the Middle Danube Region, which needs further research.

${ }^{336}$ UzsoKI 1969a, 69-82; UzsoKI 1970a, 17-57; UzsoKI

1970b, 97-108; UzsoKi 1987, 13-63.

${ }^{337}$ EGRY 2007, 32-35.

${ }^{338}$ SZABÓ 1994, 40-41.

${ }^{339}$ RAMSL 2002; RAMSL 2011.

${ }^{340}$ Bella 1889, 361-366; Bella 1894, 301-305.

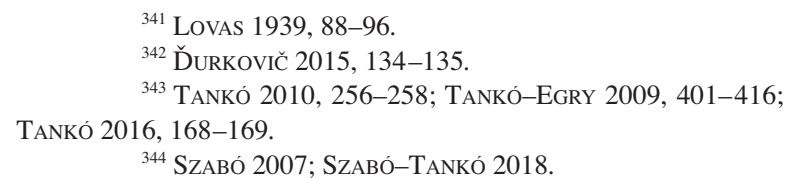

${ }^{341}$ LOVAS 1939, 88-96.

${ }^{343}$ TANKÓ 2010, 256-258; TANKÓ-EGRY 2009, 401-416;

${ }^{344}$ SZABÓ 2007; SZABÓ-TANKó 2018. 


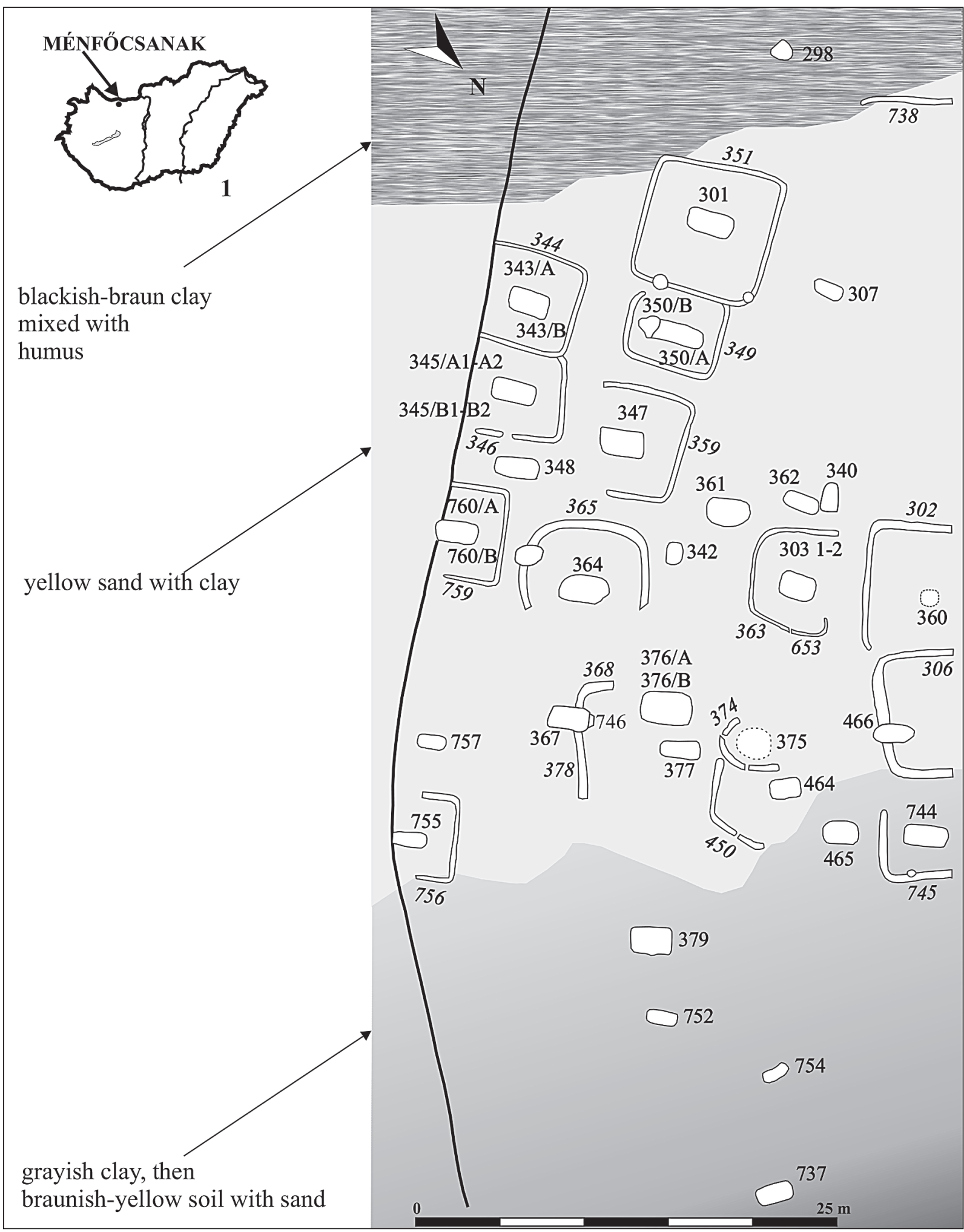

Fig. 1. 1: Location of the site; 2: Celtic cemetery without the other features 


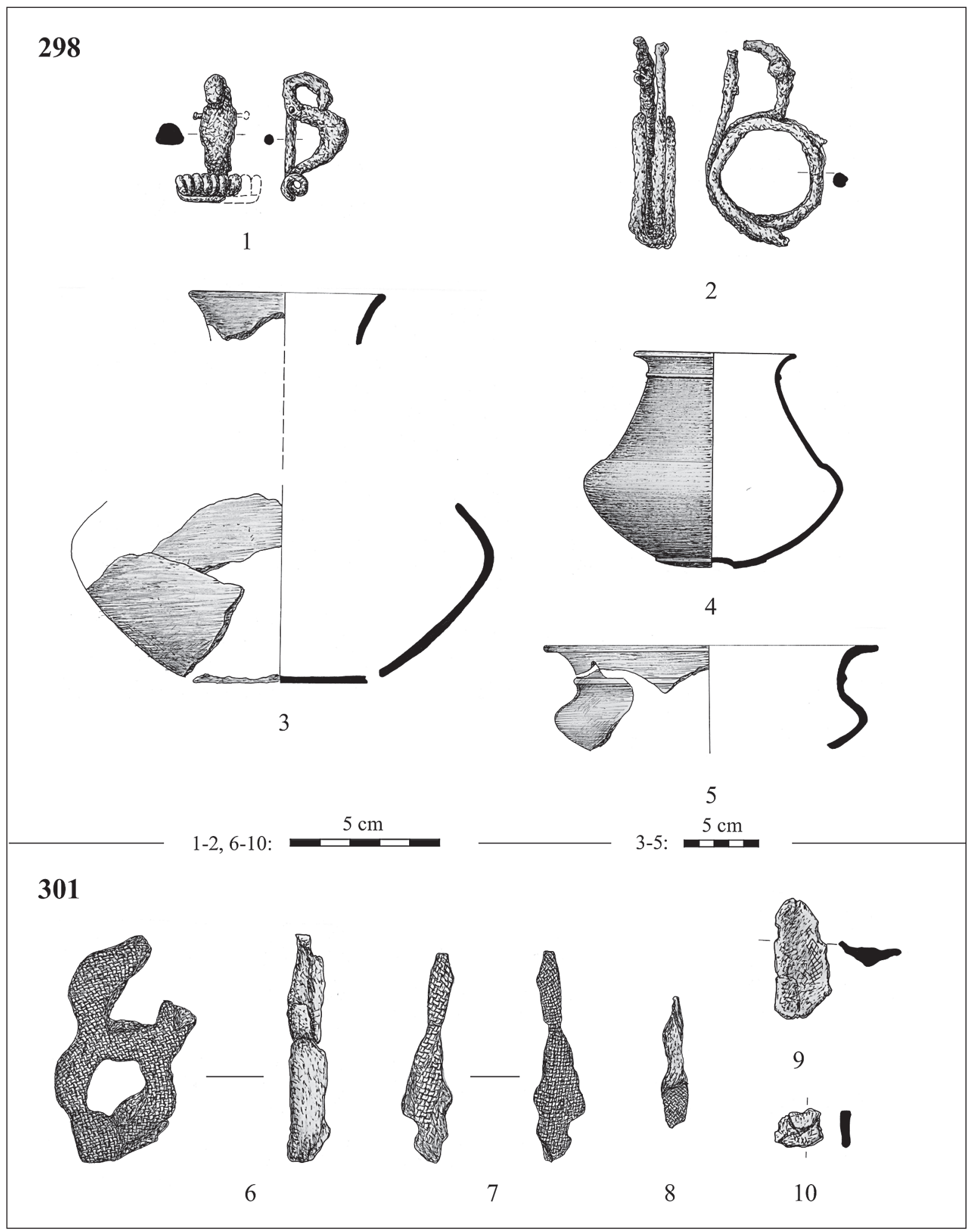

Fig. 2. 1-5: Grave no. 298; 6-10: Grave no. 301 
301
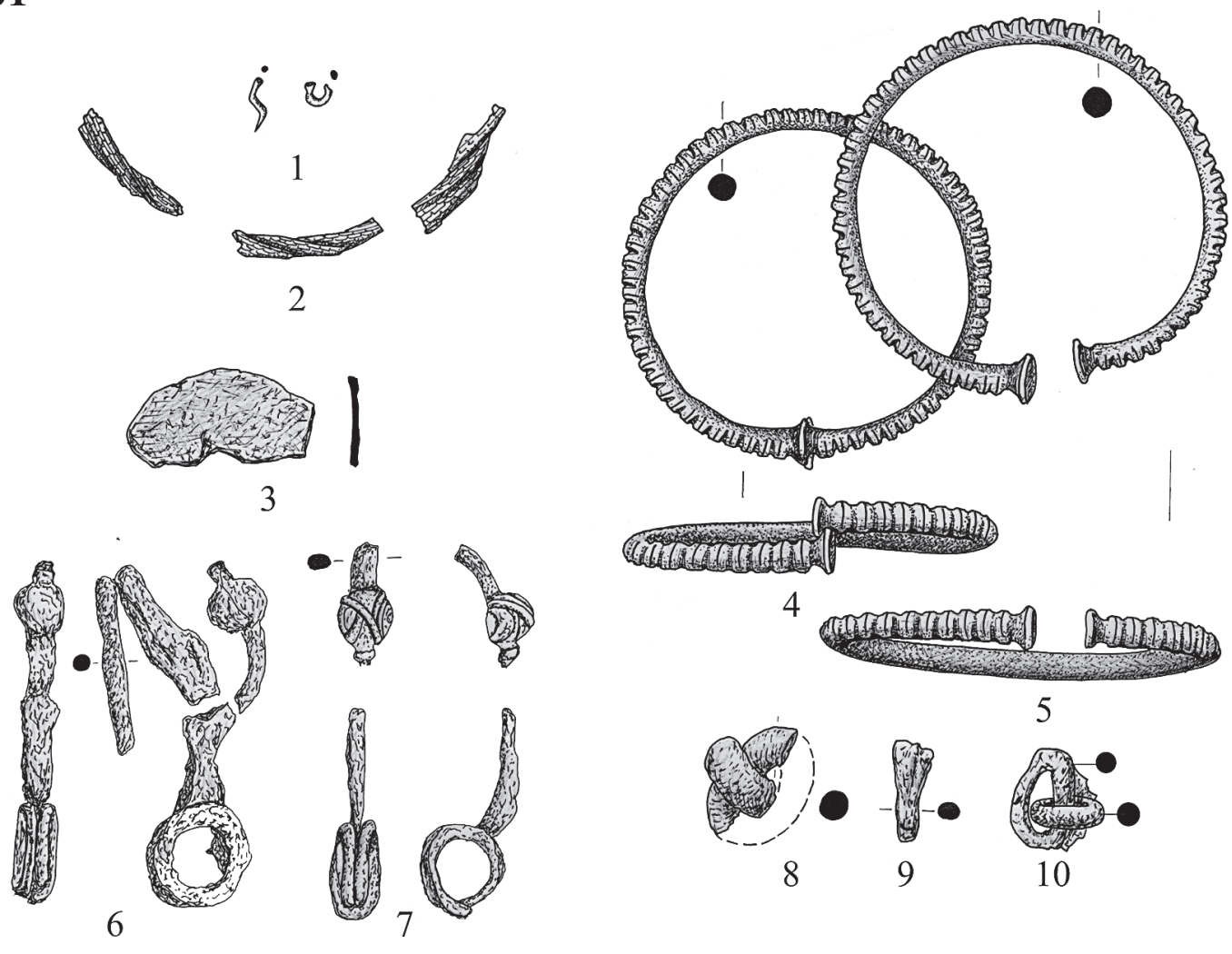

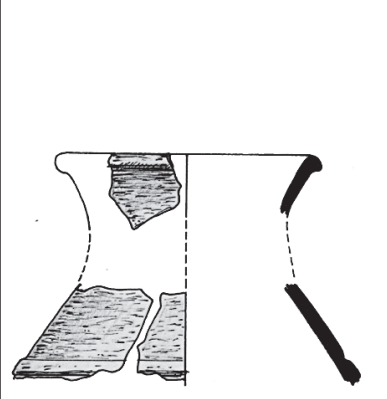

11
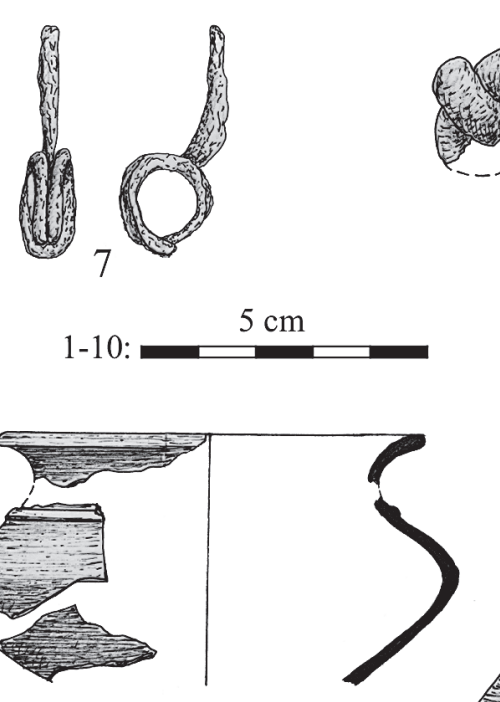

12
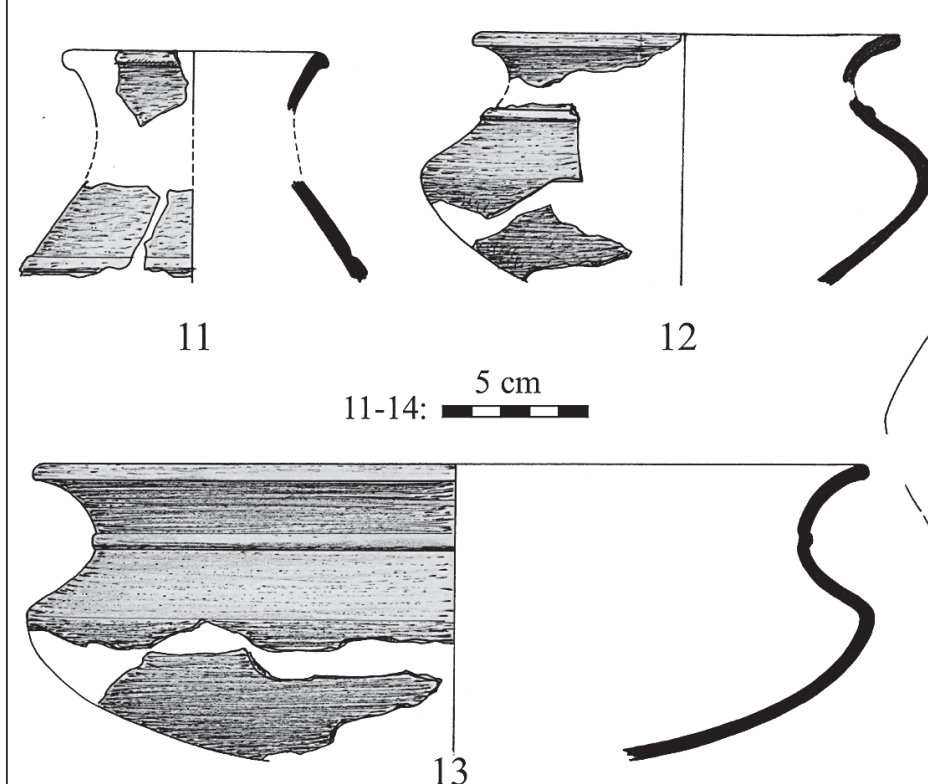

$5 \mathrm{~cm}$
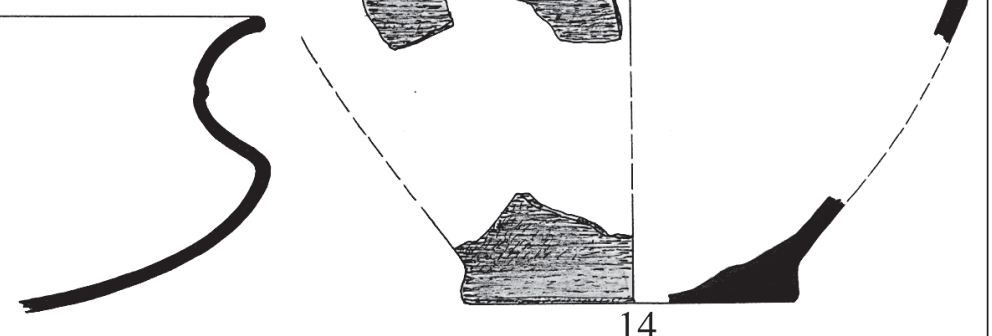

Fig. 3. 1-14: Grave no. 301 


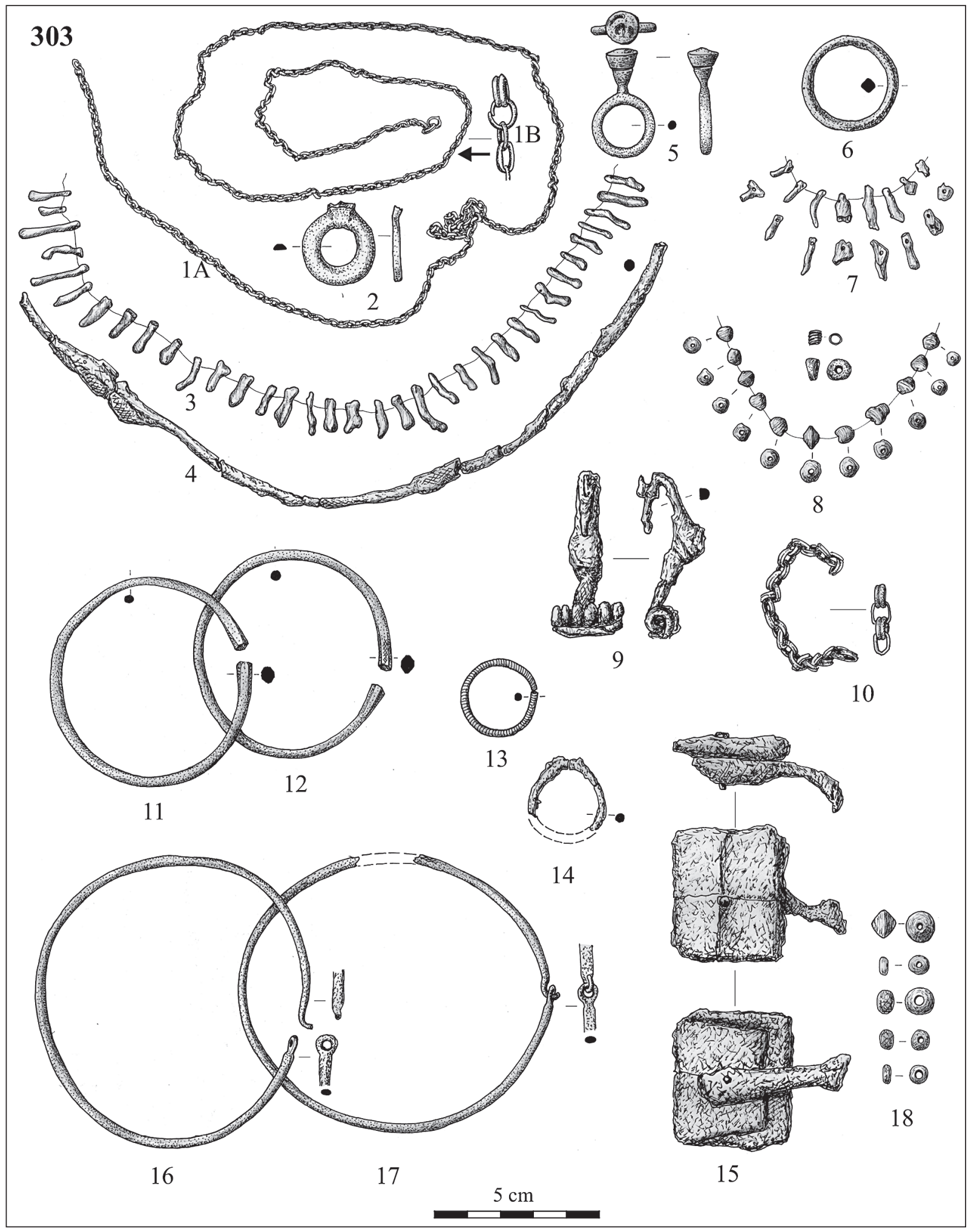

Fig. 4.1-18: Grave no. 303 


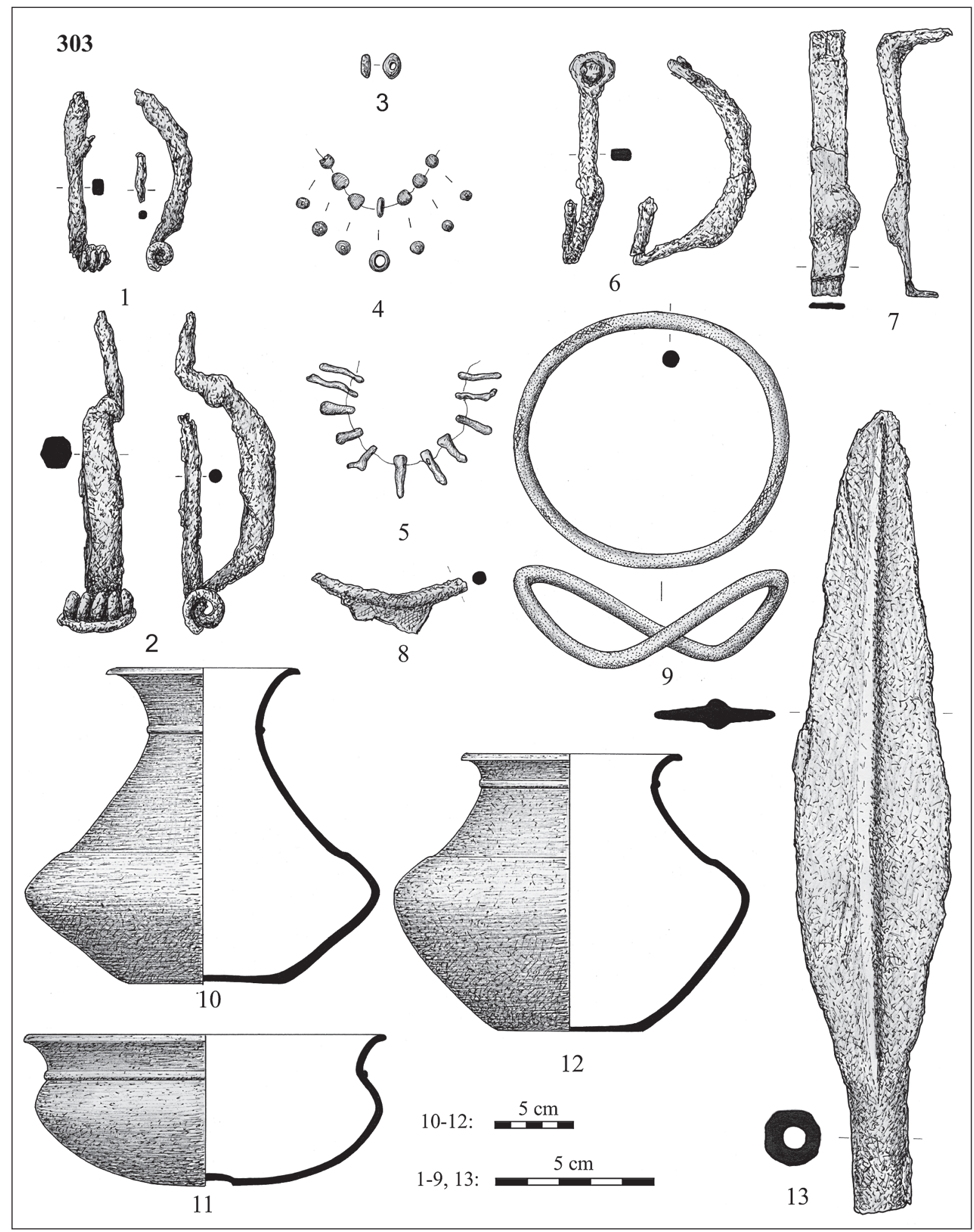

Fig. 5. 1-13: Grave no. 303 


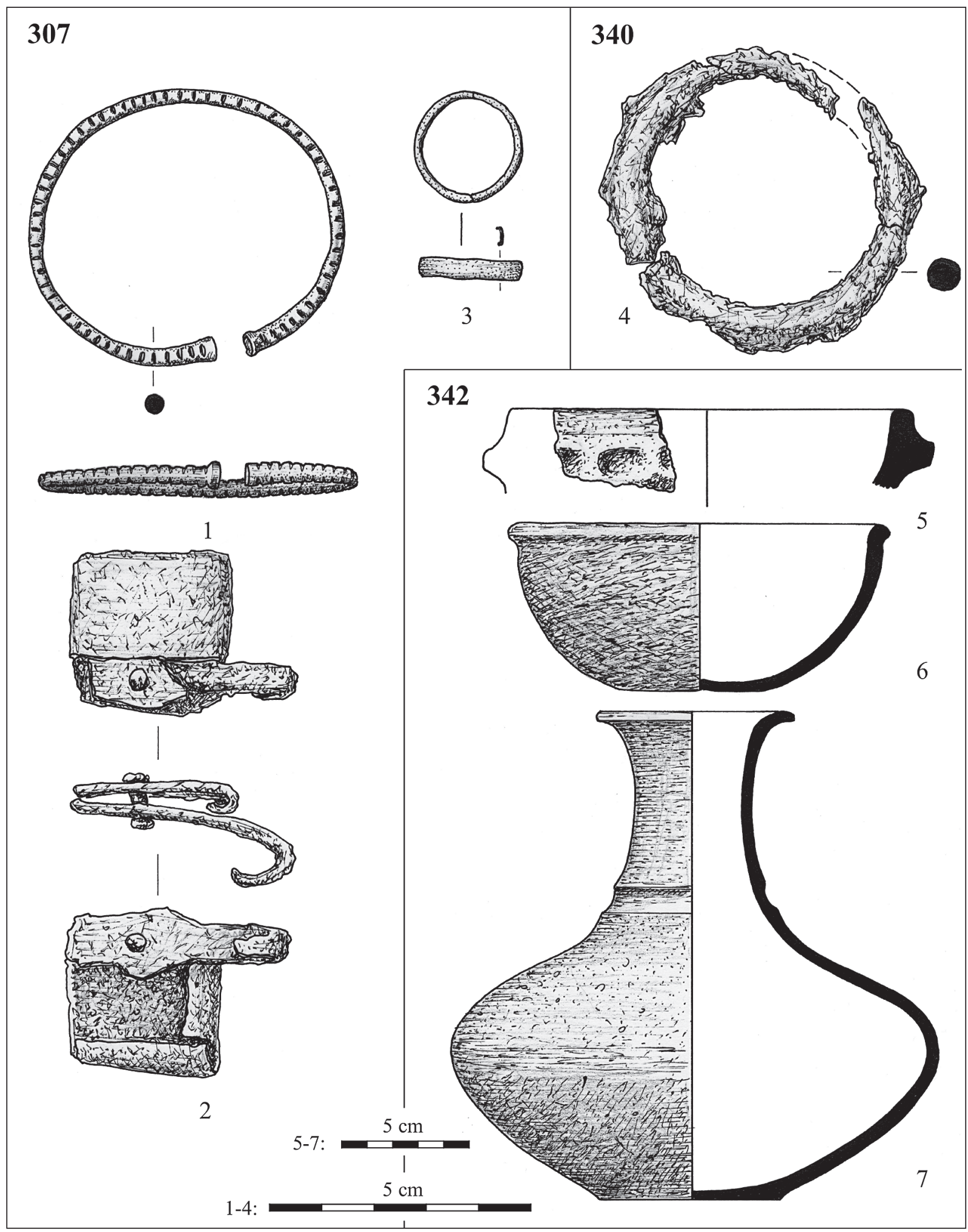

Fig. 6. 1-3: Grave no. 307; 4: Grave no. 340; 5-7: Grave no. 342 


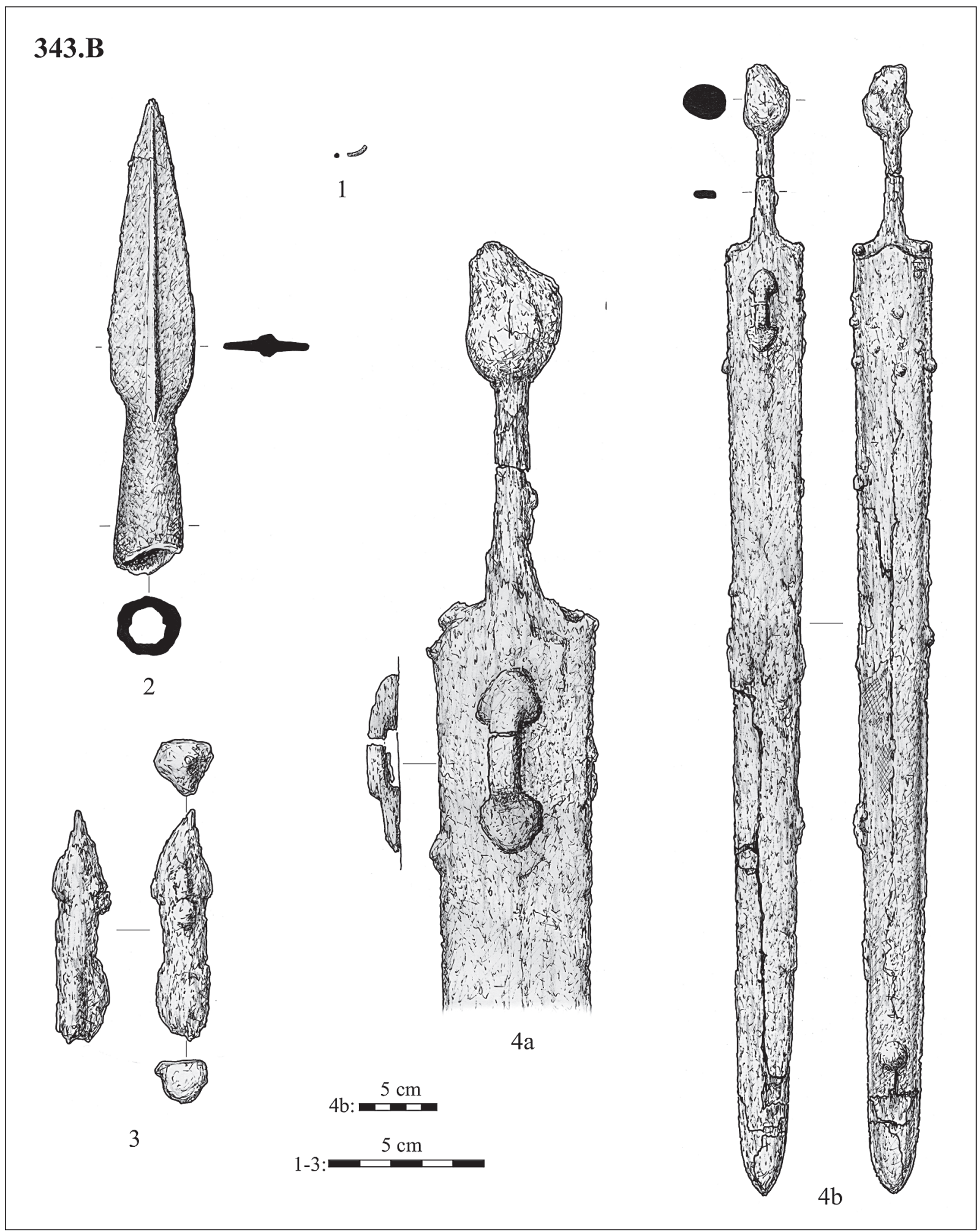

Fig. 7. 1-4: Grave no. 343/B 


\section{B}

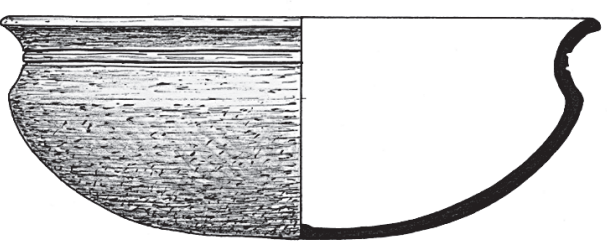

1

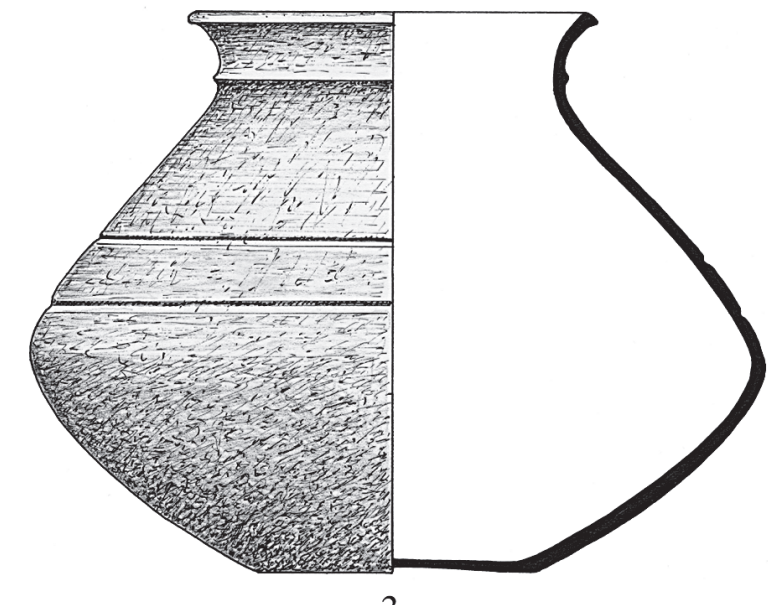

3

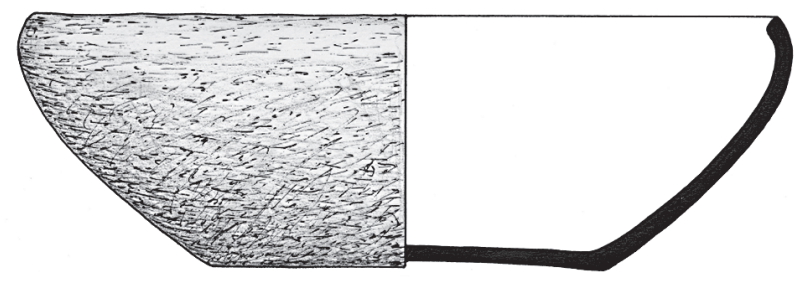

2

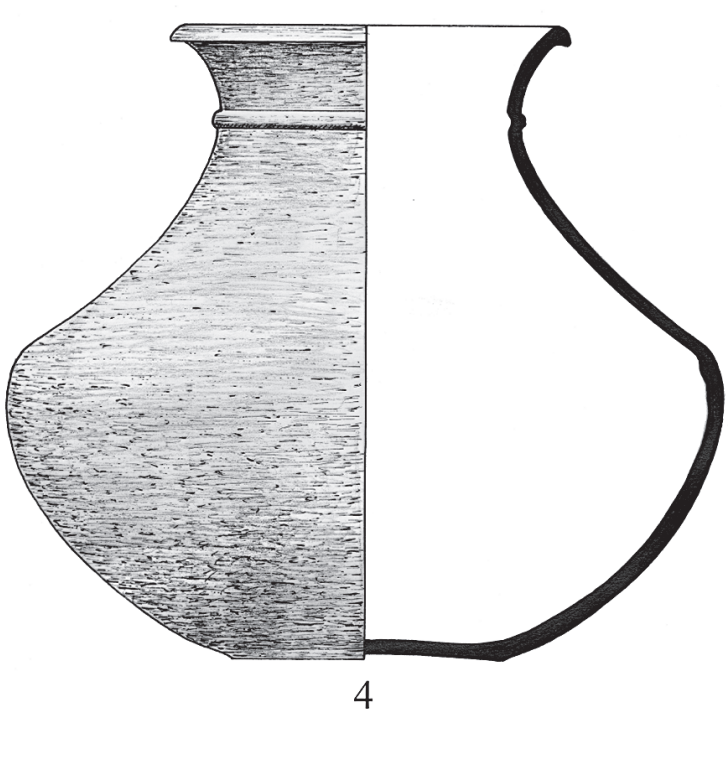

$5 \mathrm{~cm}$

\section{B1}
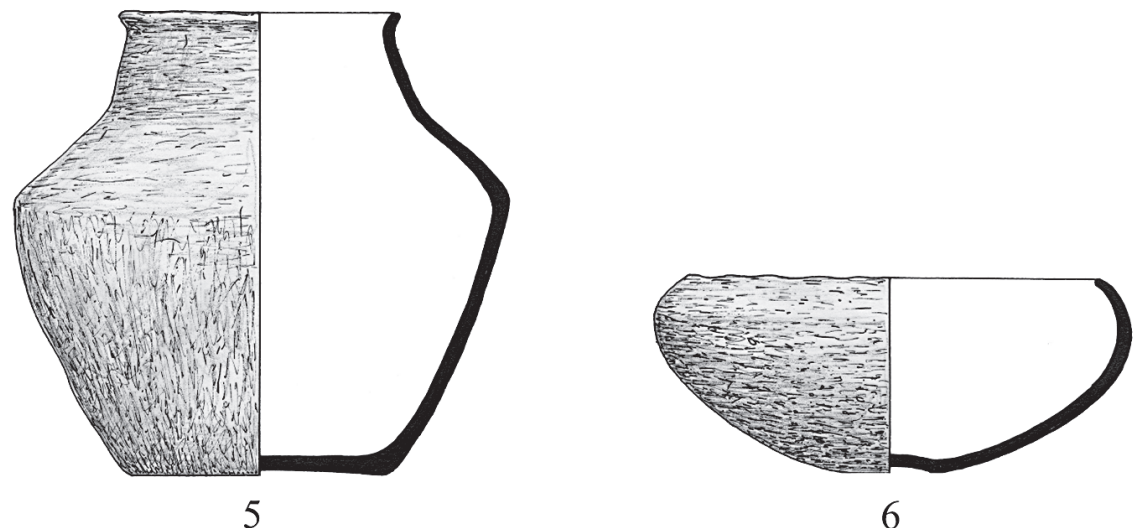

Fig. 8. 1-4: Grave no. 343/B; 5-6: Grave no. 345/B 


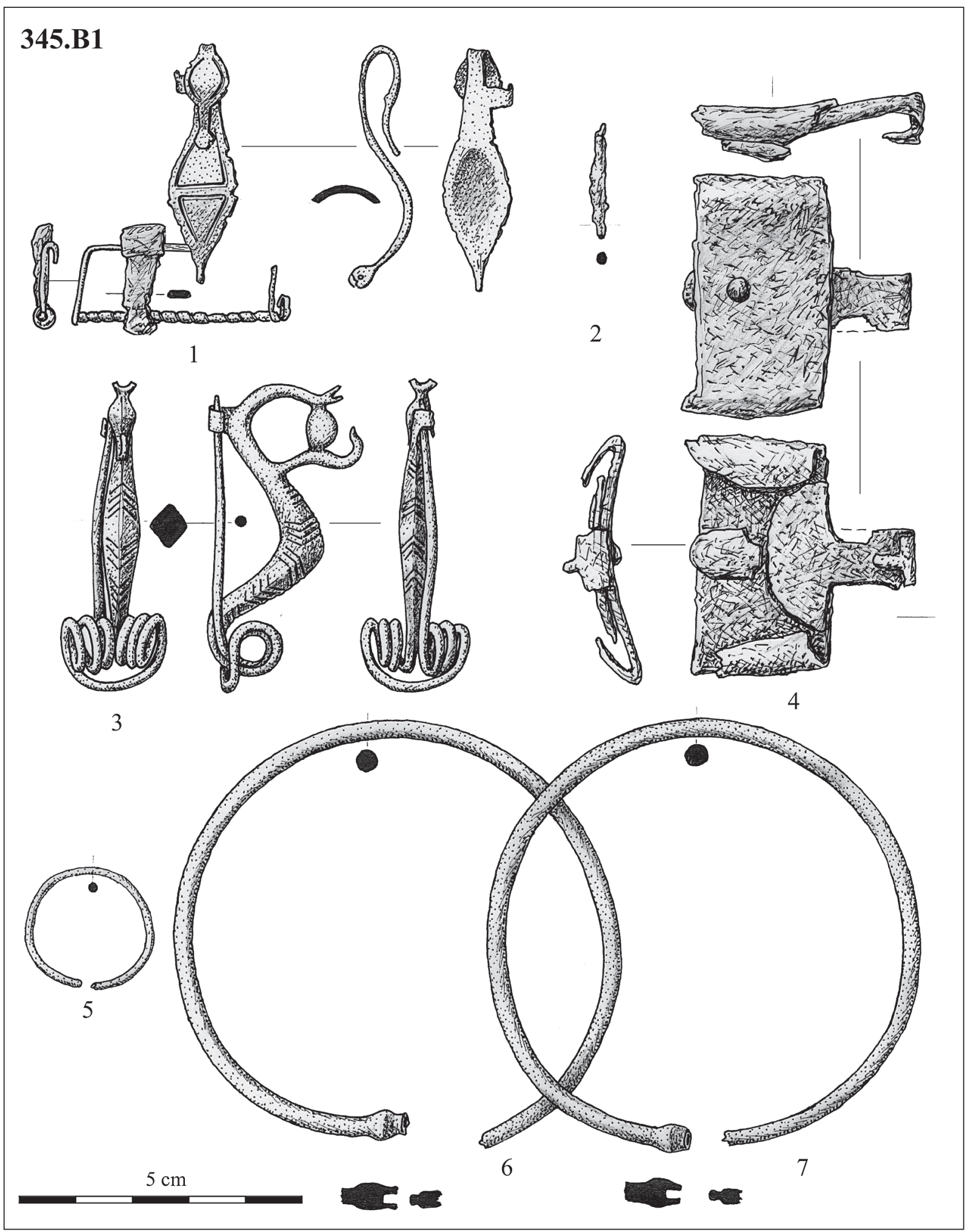

Fig. 9. 1-7: Grave no. 345/B1 


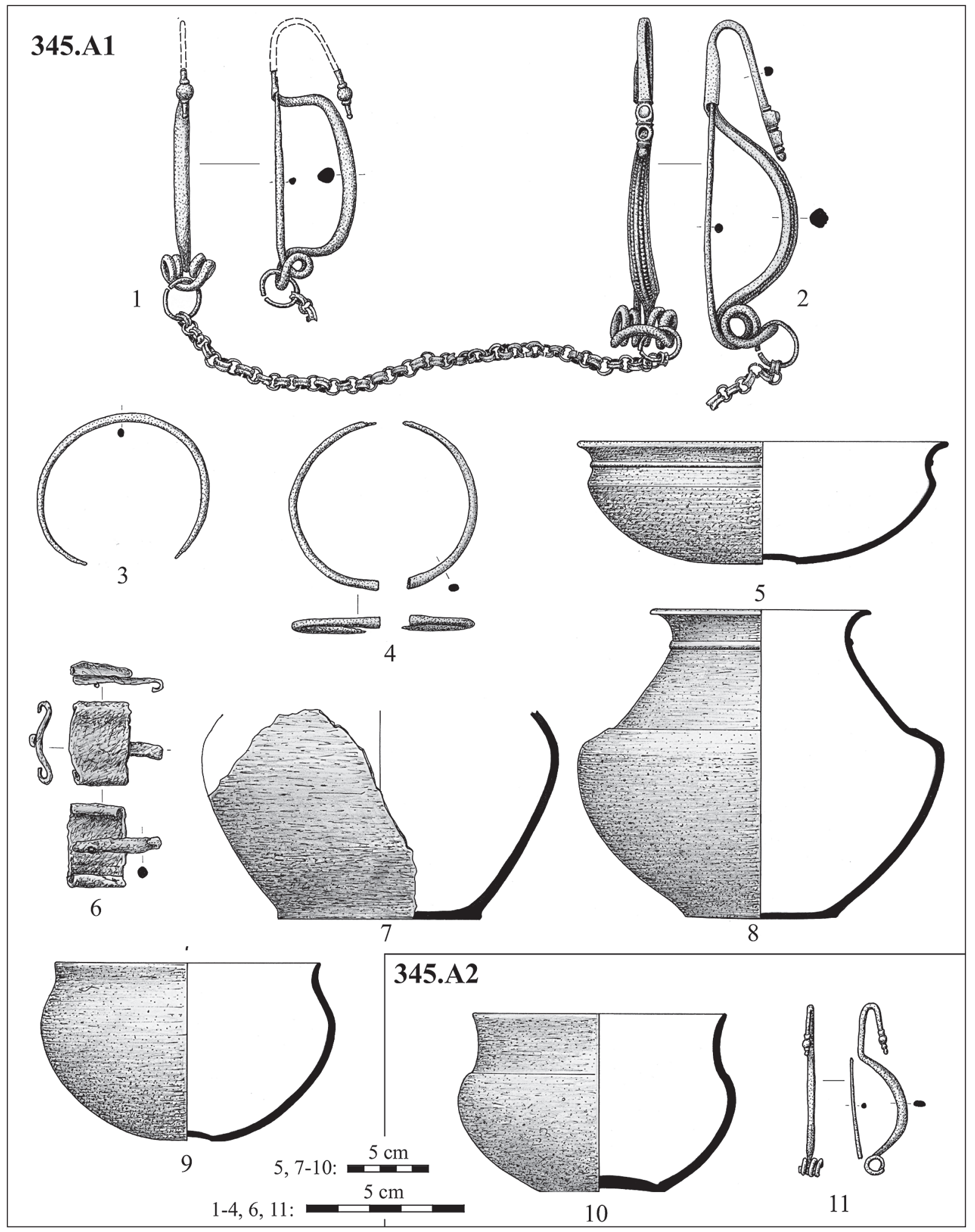

Fig. 10. 1-9: Grave no. 345/A1; 10-11: Grave no. 345/A2 


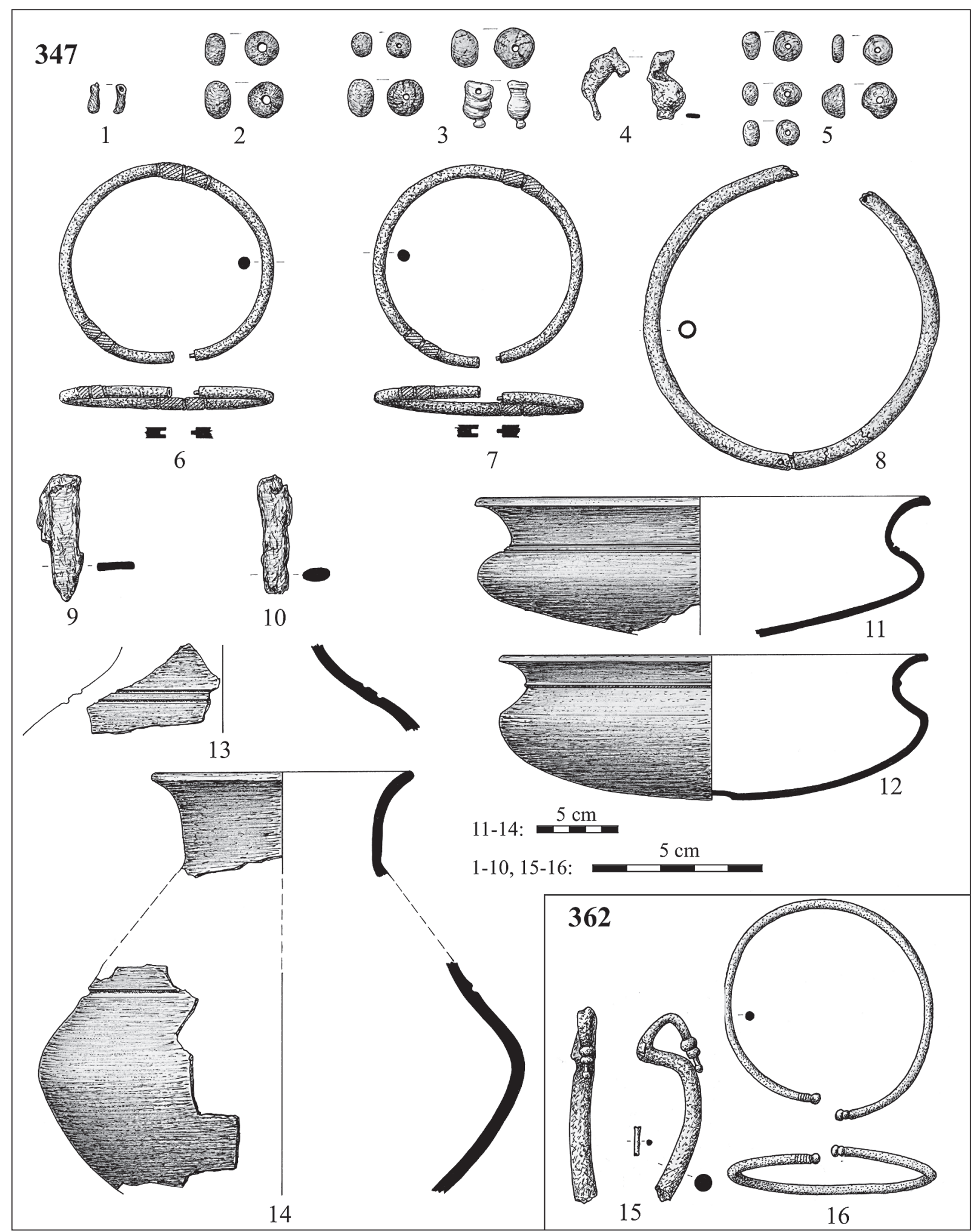

Fig. 11.1-14: Grave no. 347; 15-16: Grave no. 362 


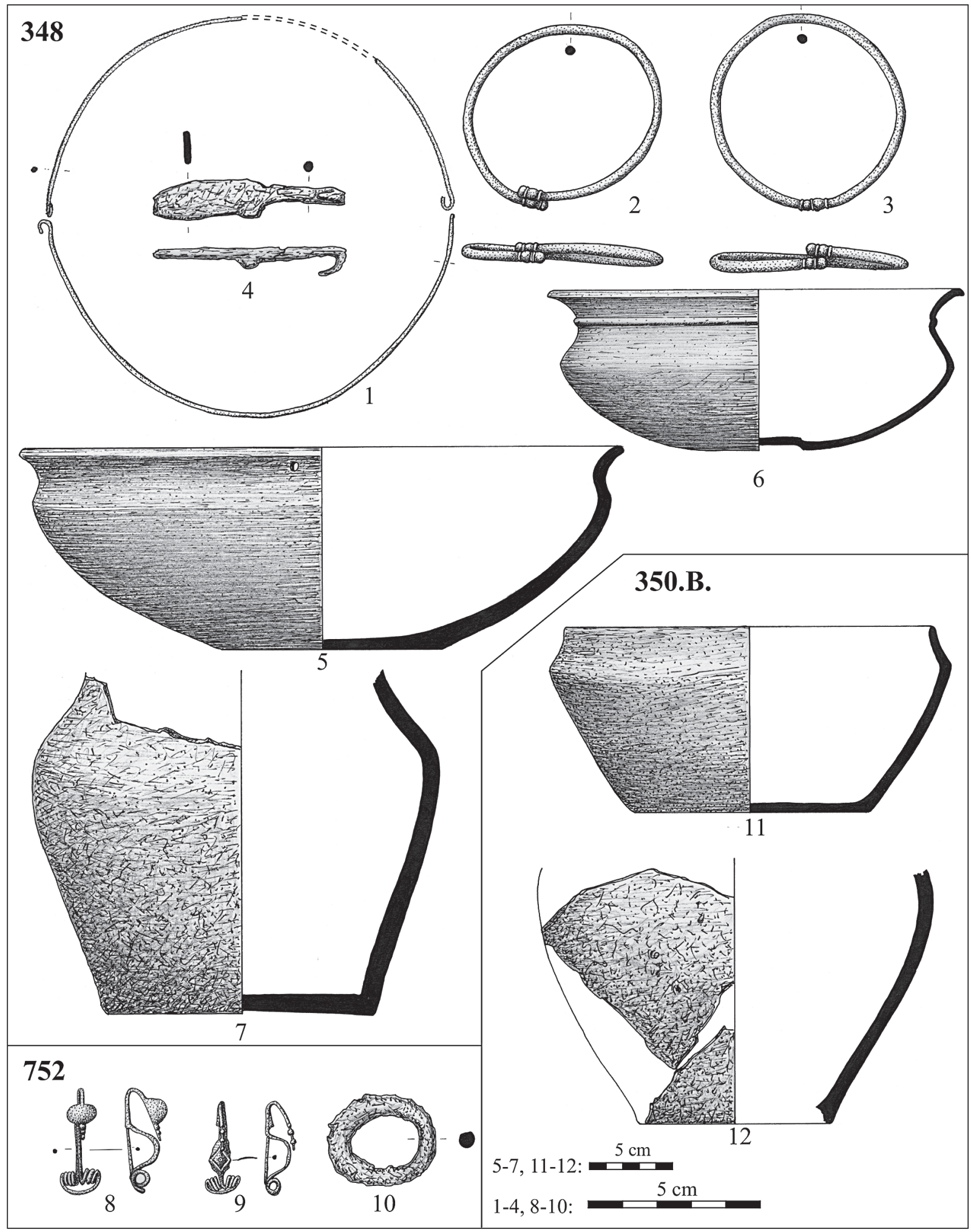

Fig. 12. 1-7: Grave no. 348; 8-10: Grave no. 752; 11-12: Grave no. 350/B 


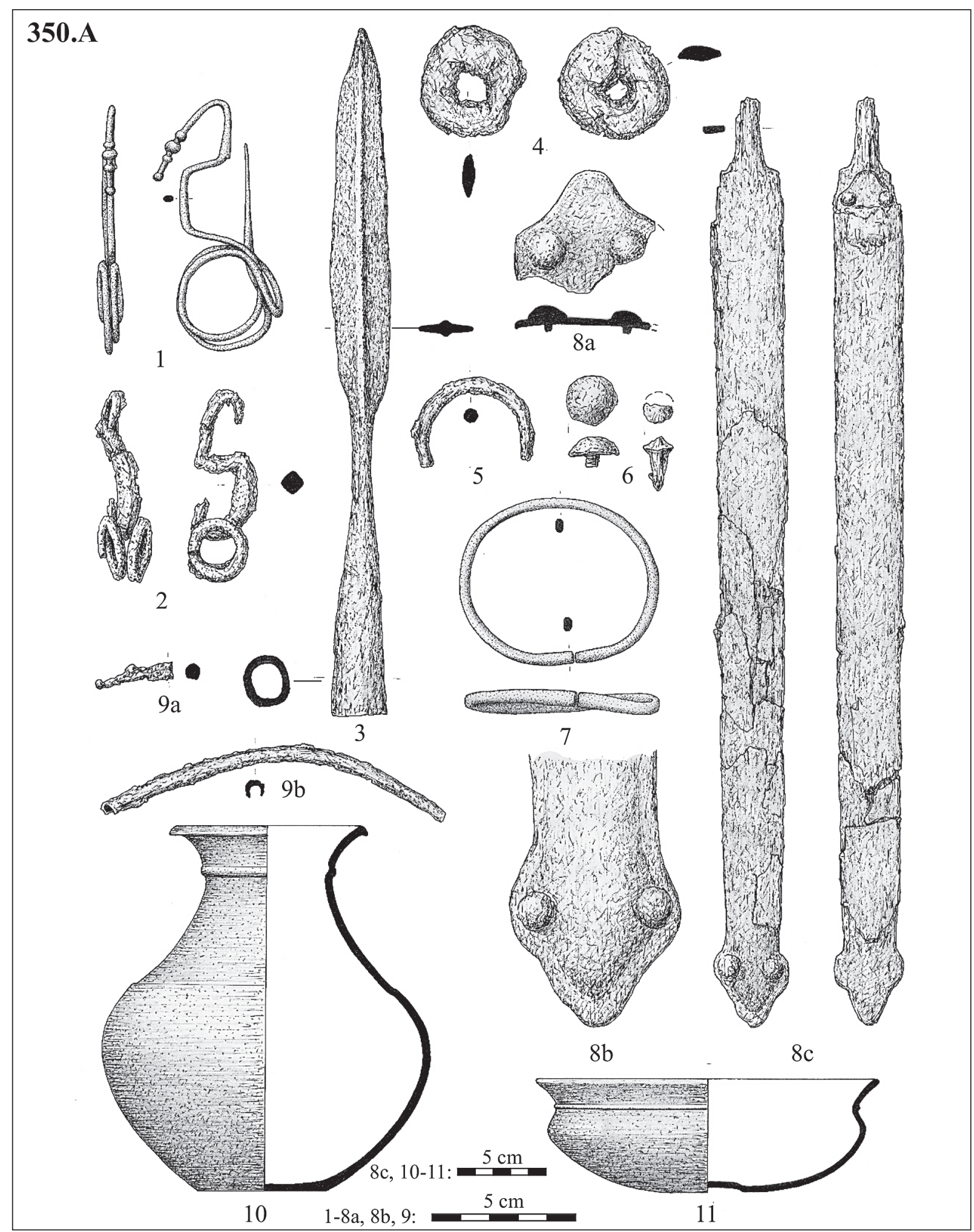

Fig. 13. 1-11: Grave no. 350/A 


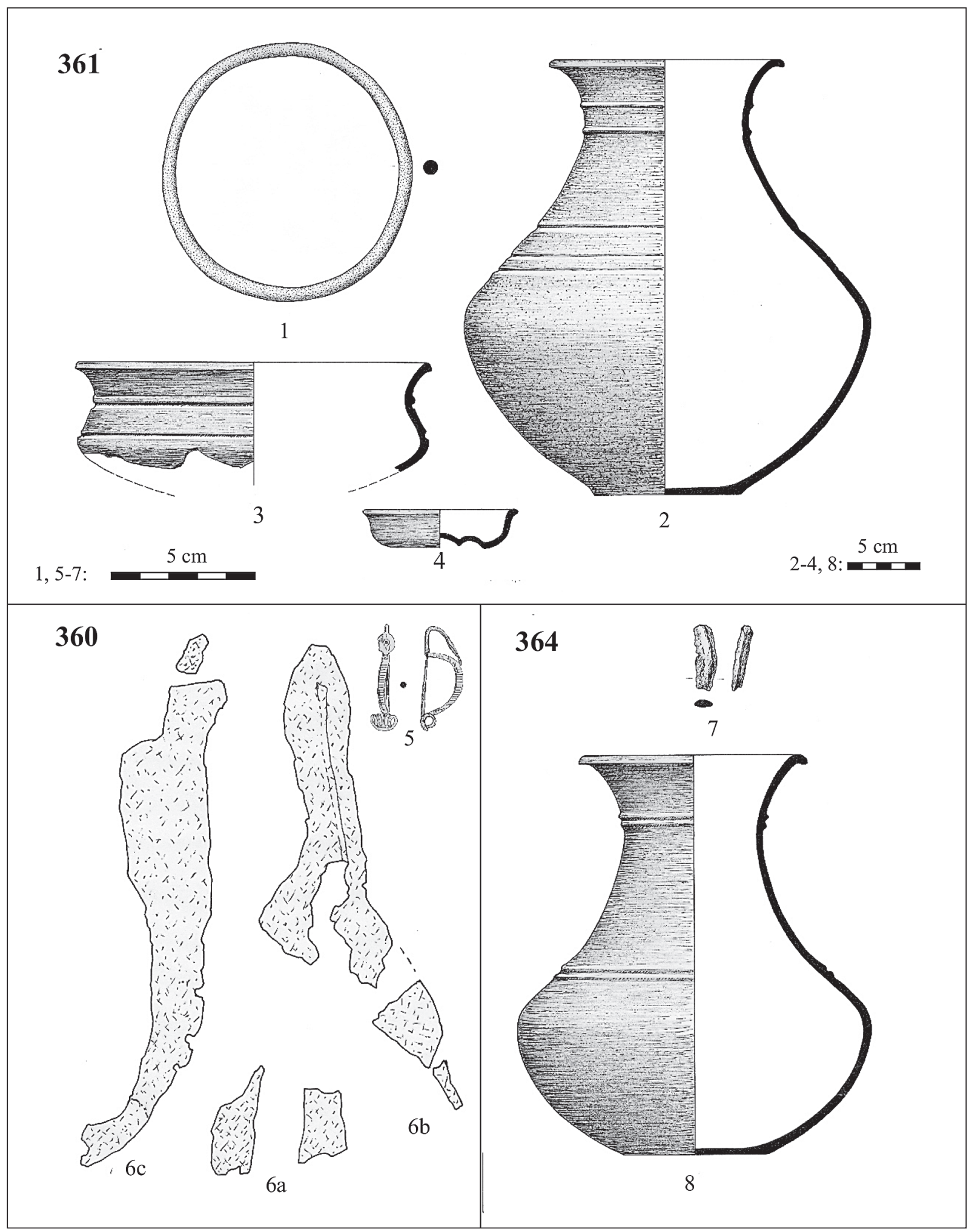

Fig. 14. 1-4: Grave no. 361; 5-6: Grave no. 60; 7-8: Grave no. 364 


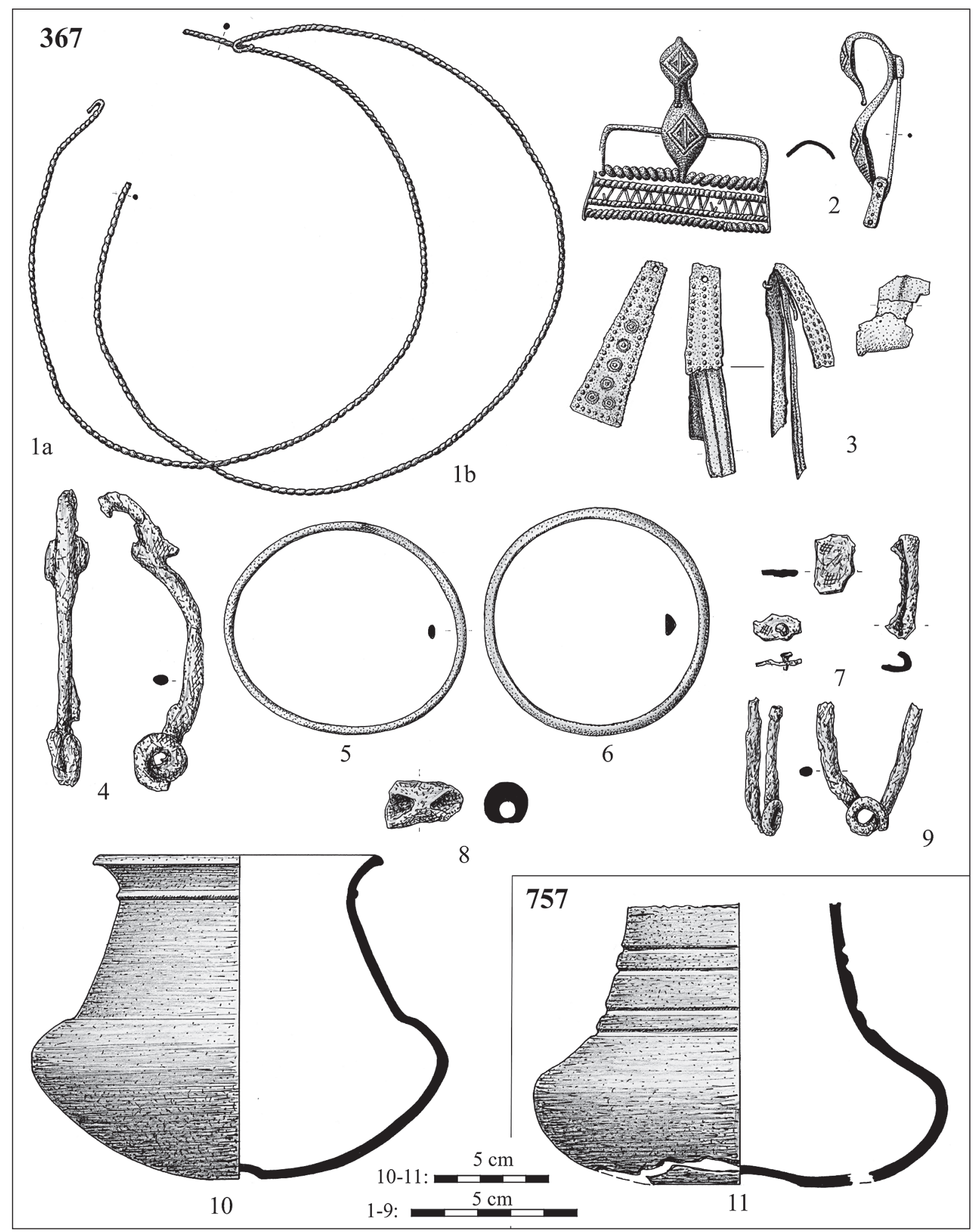

Fig. 15. 1-10: Grave no. 367; 11: Grave no. 757 


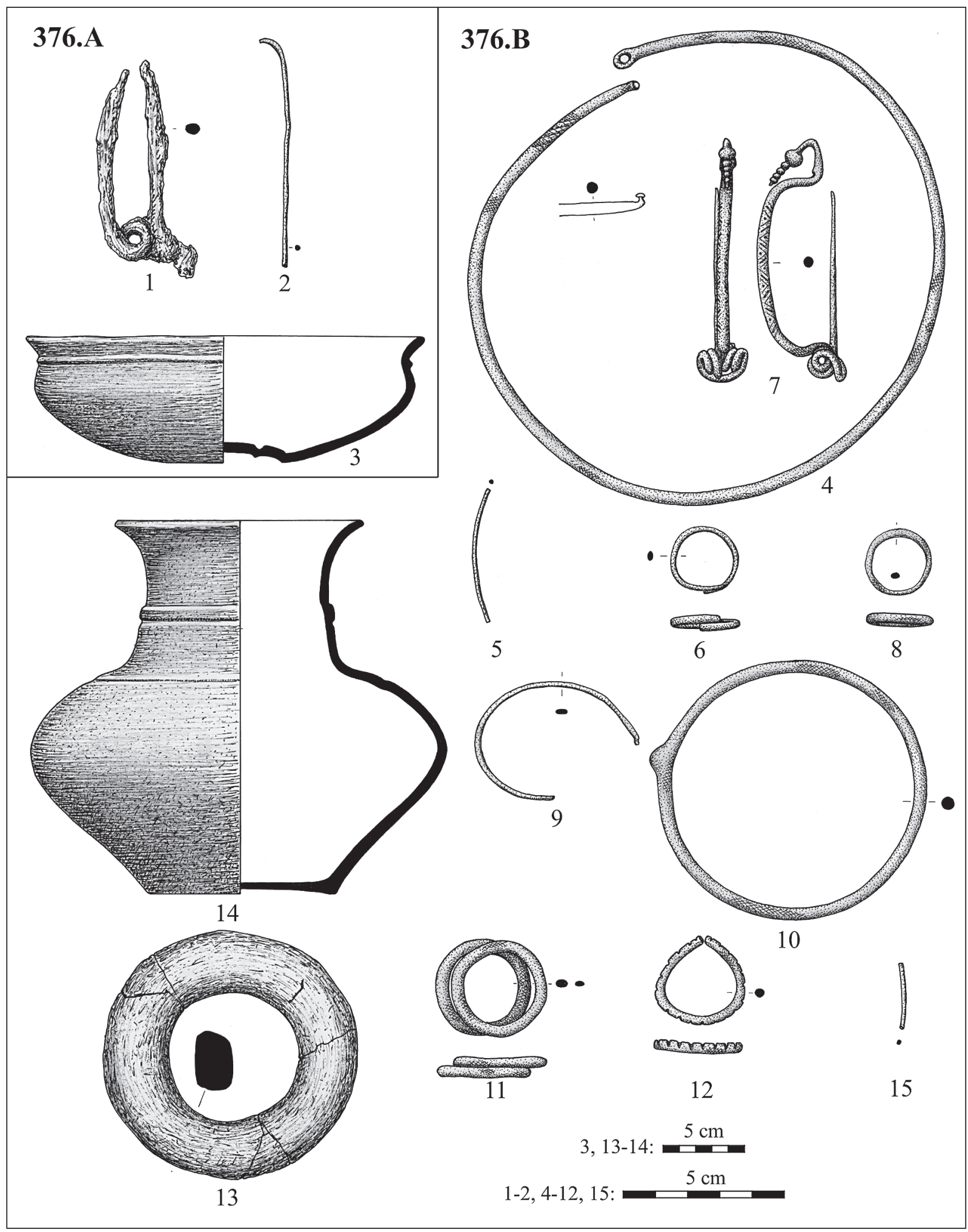

Fig.16. 1-3: Grave no. 376/A; 4-15: Grave no. 376/B 


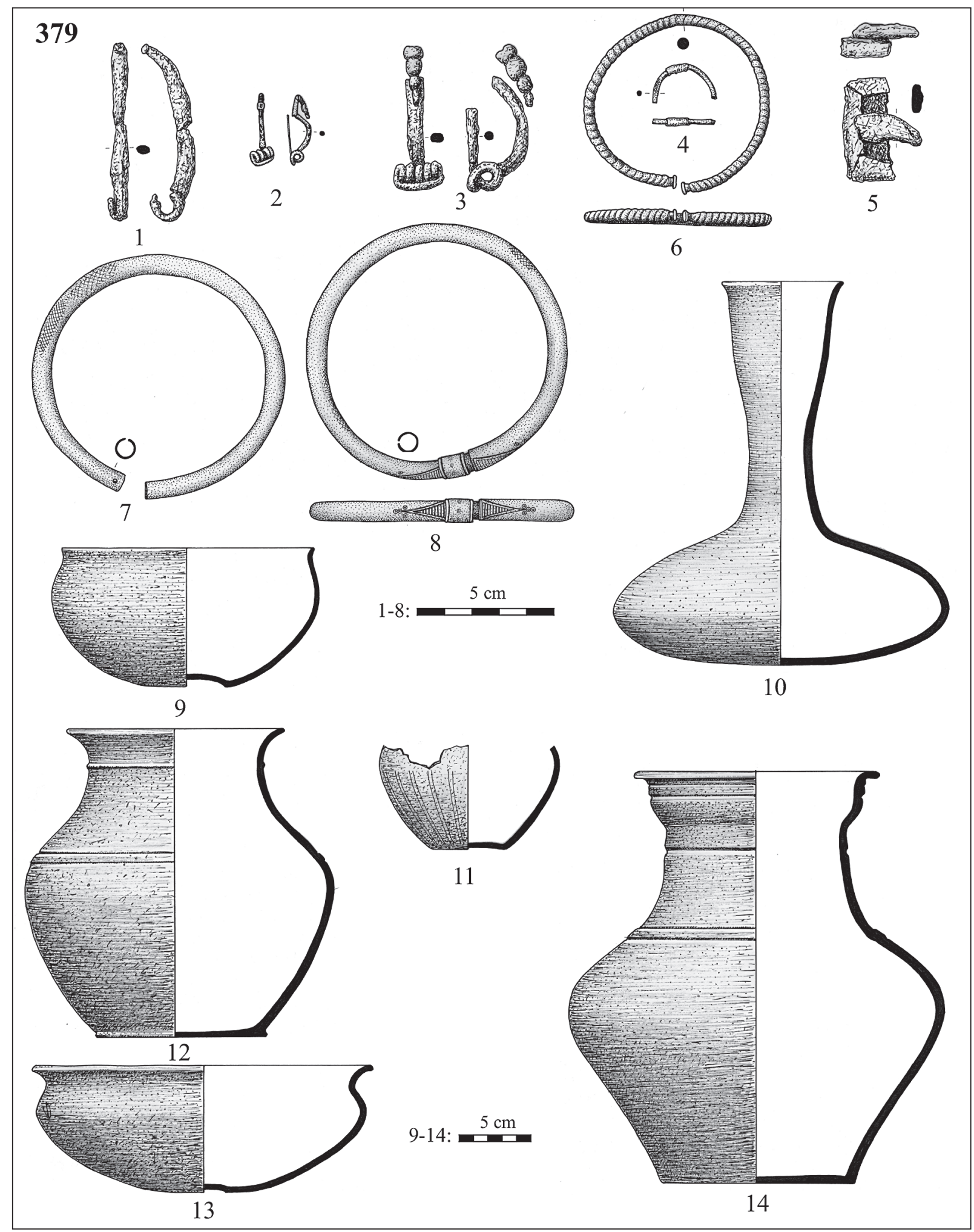

Fig. 17. 1-14: Grave no. 379. 


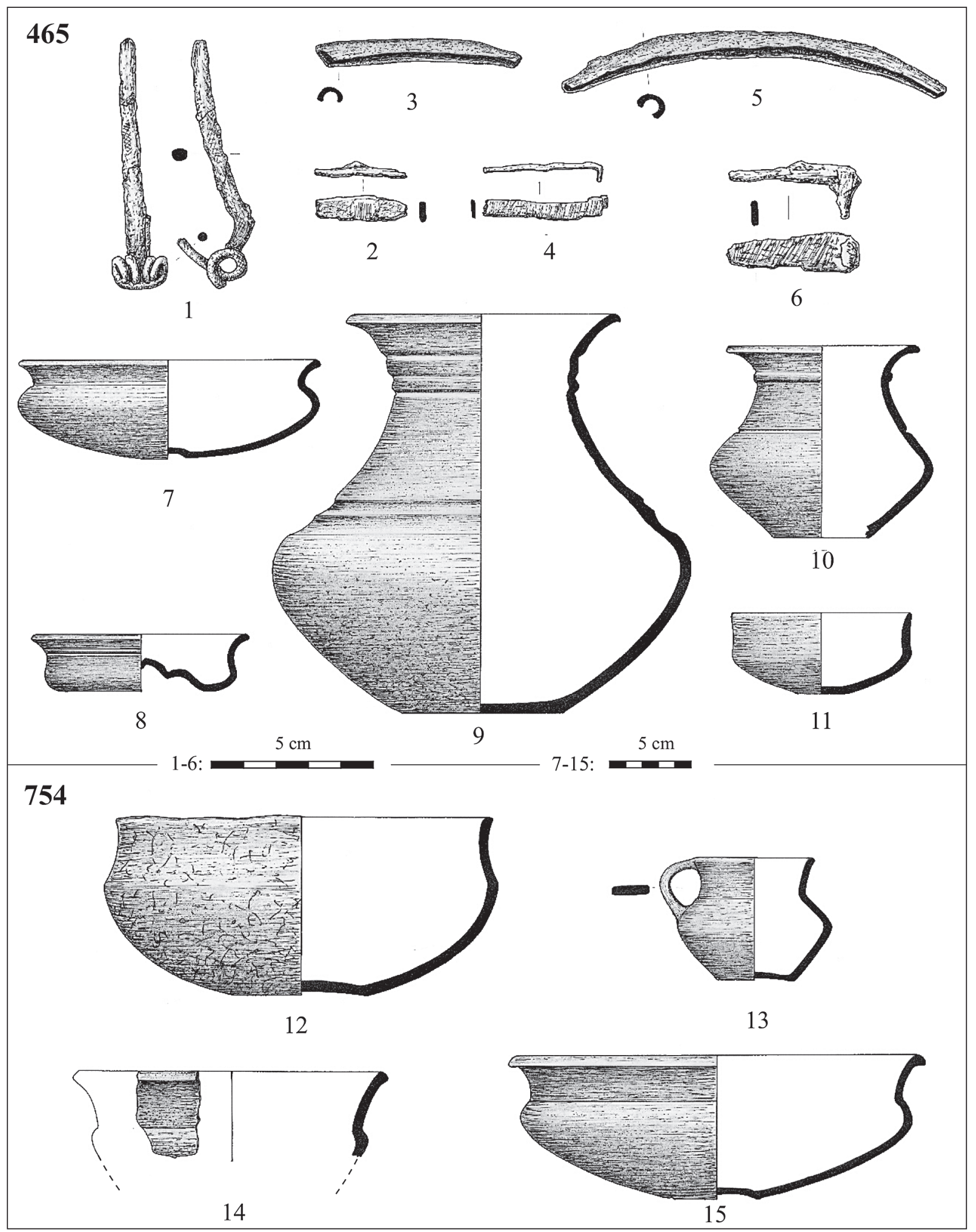

Fig. 18. 1-11: Grave no. 465; 12-15: Grave no. 754 


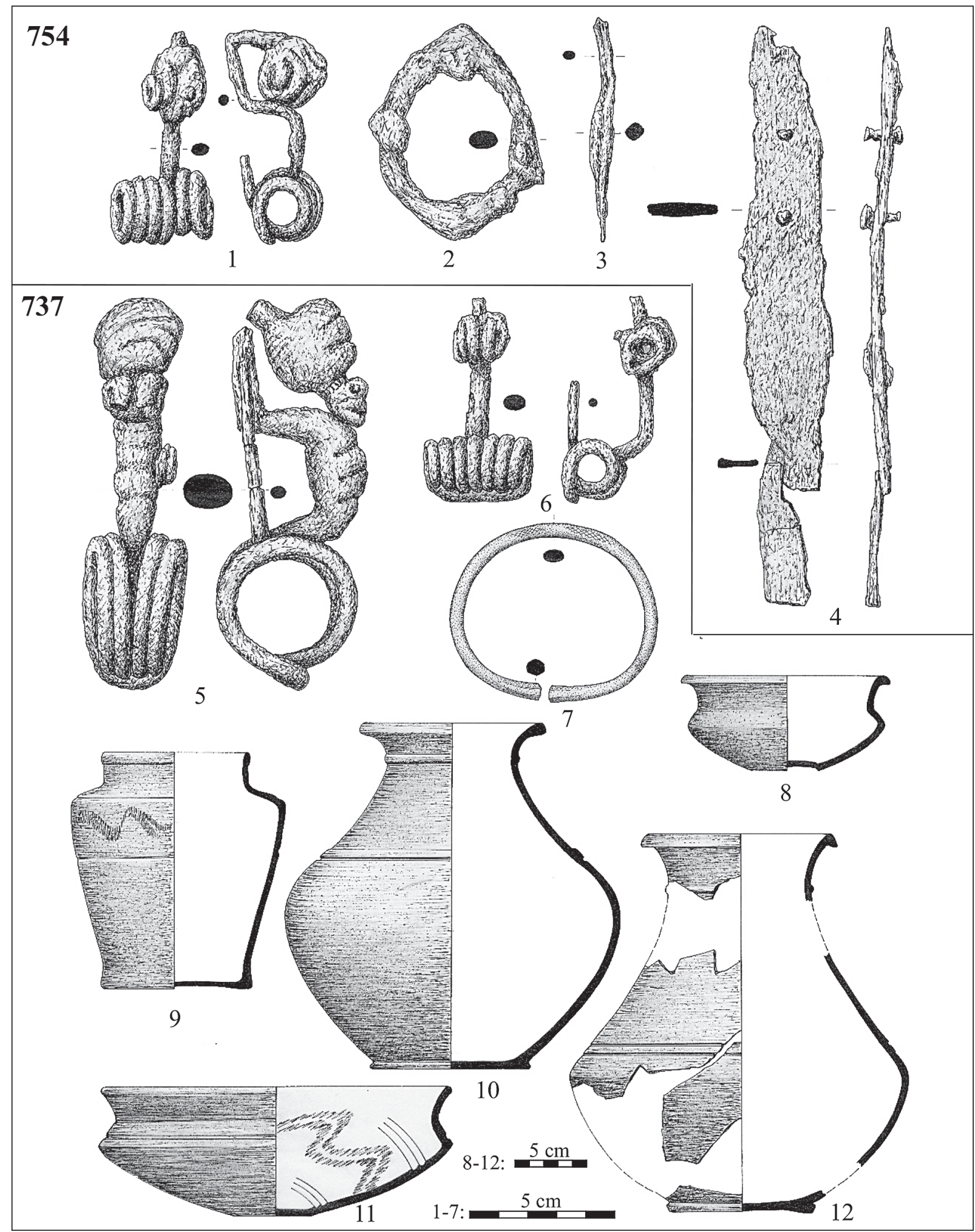

Fig. 19. 1-4: Grave no. 754; 5-12: Grave no. 737 


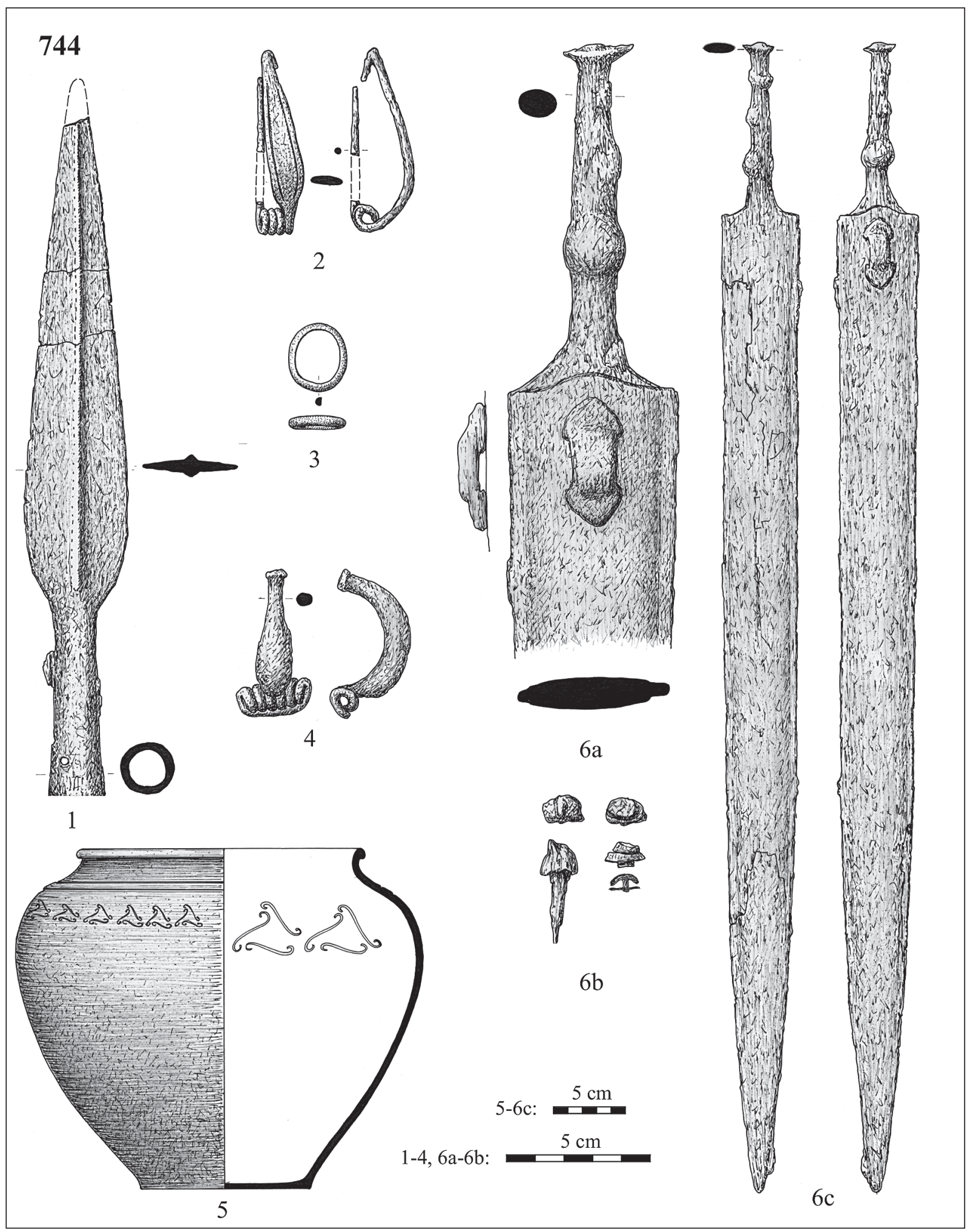

Fig. 20. 1-6: Grave no. 744 


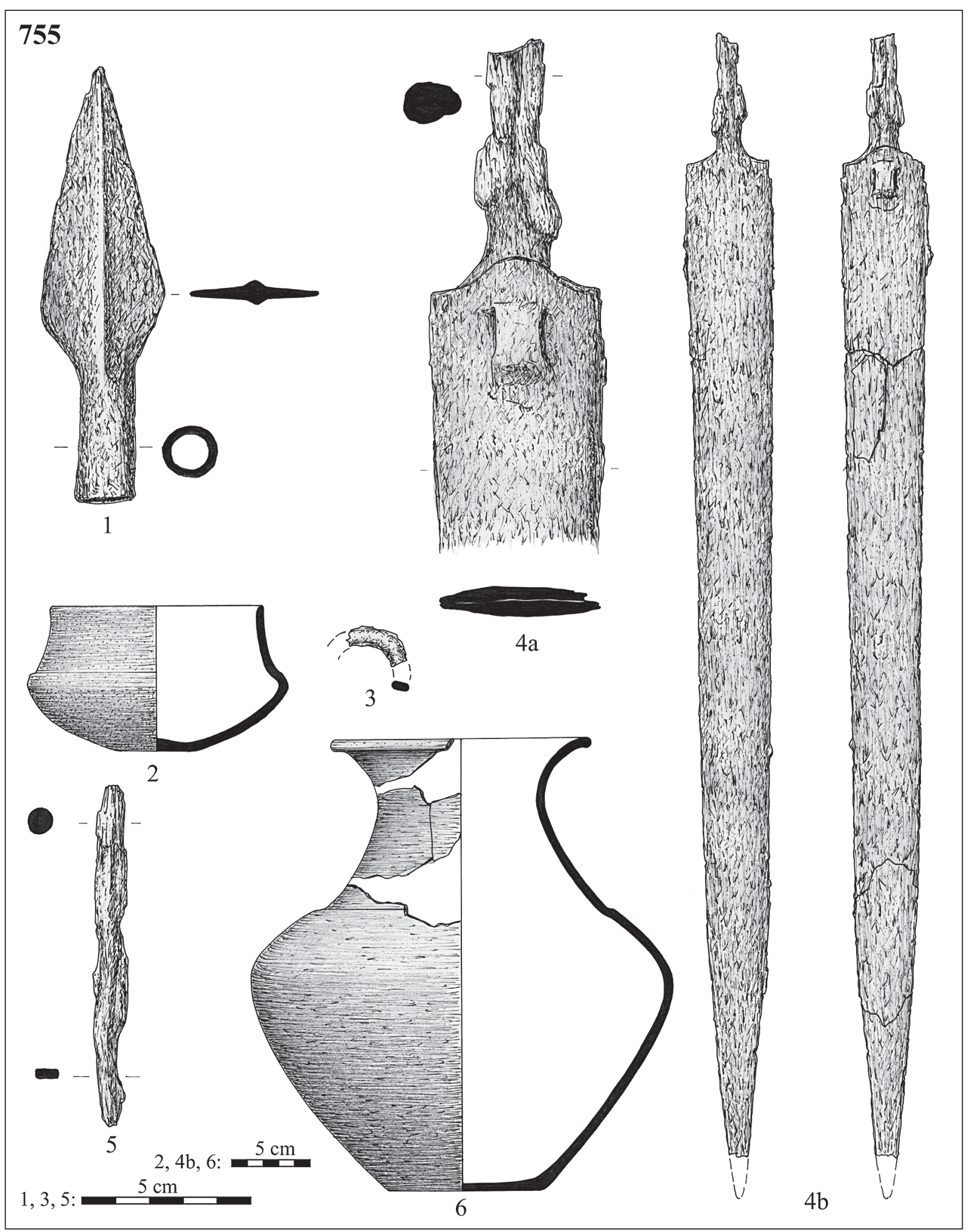

Fig. 21.1-6: Grave no. 755 


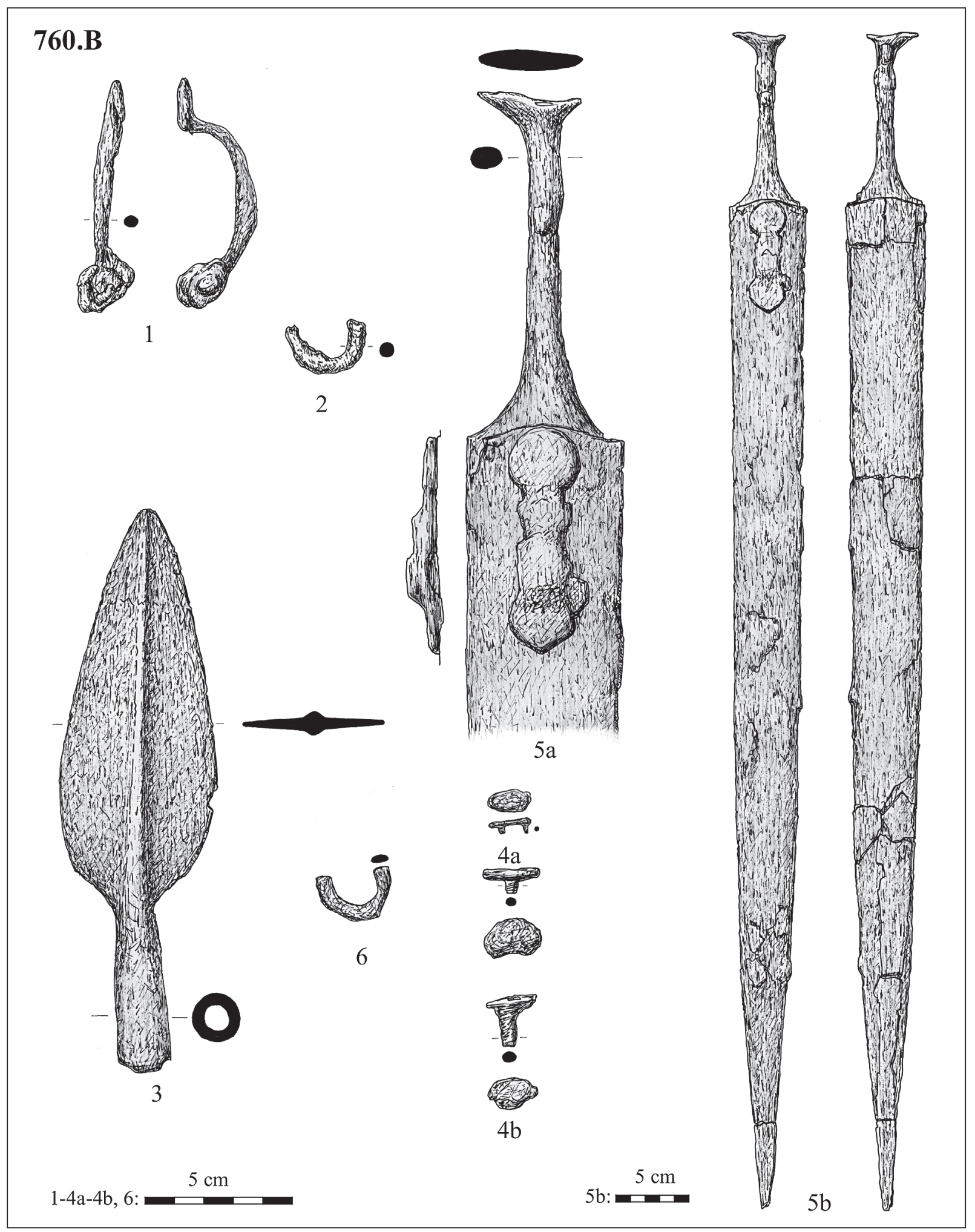

Fig. 22. 1-6: Grave no. 760/B 


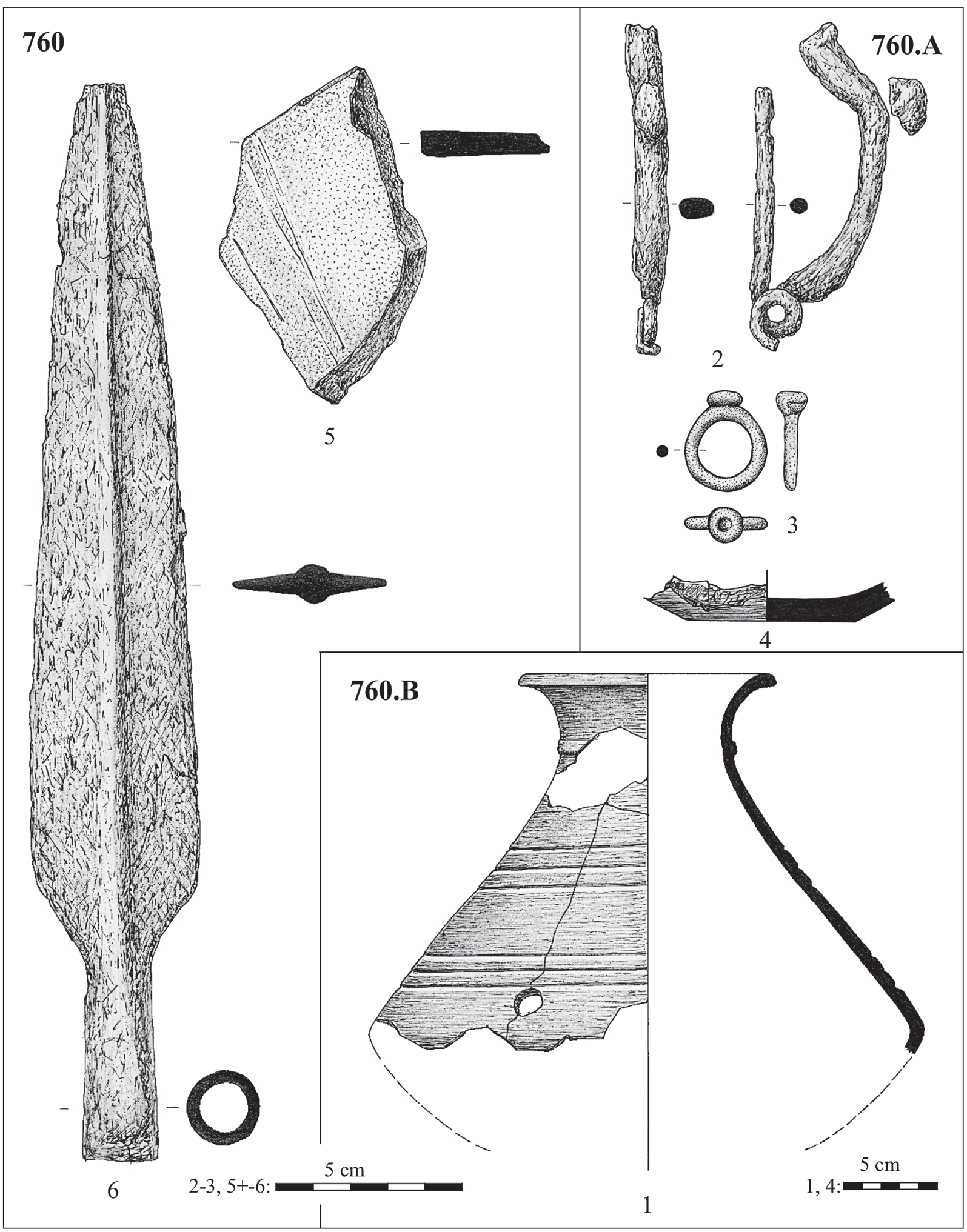

Fig. 23. 1: Grave no. 760/B; 2-4: Grave no. 760/A; 5-6: Grave no. 760 


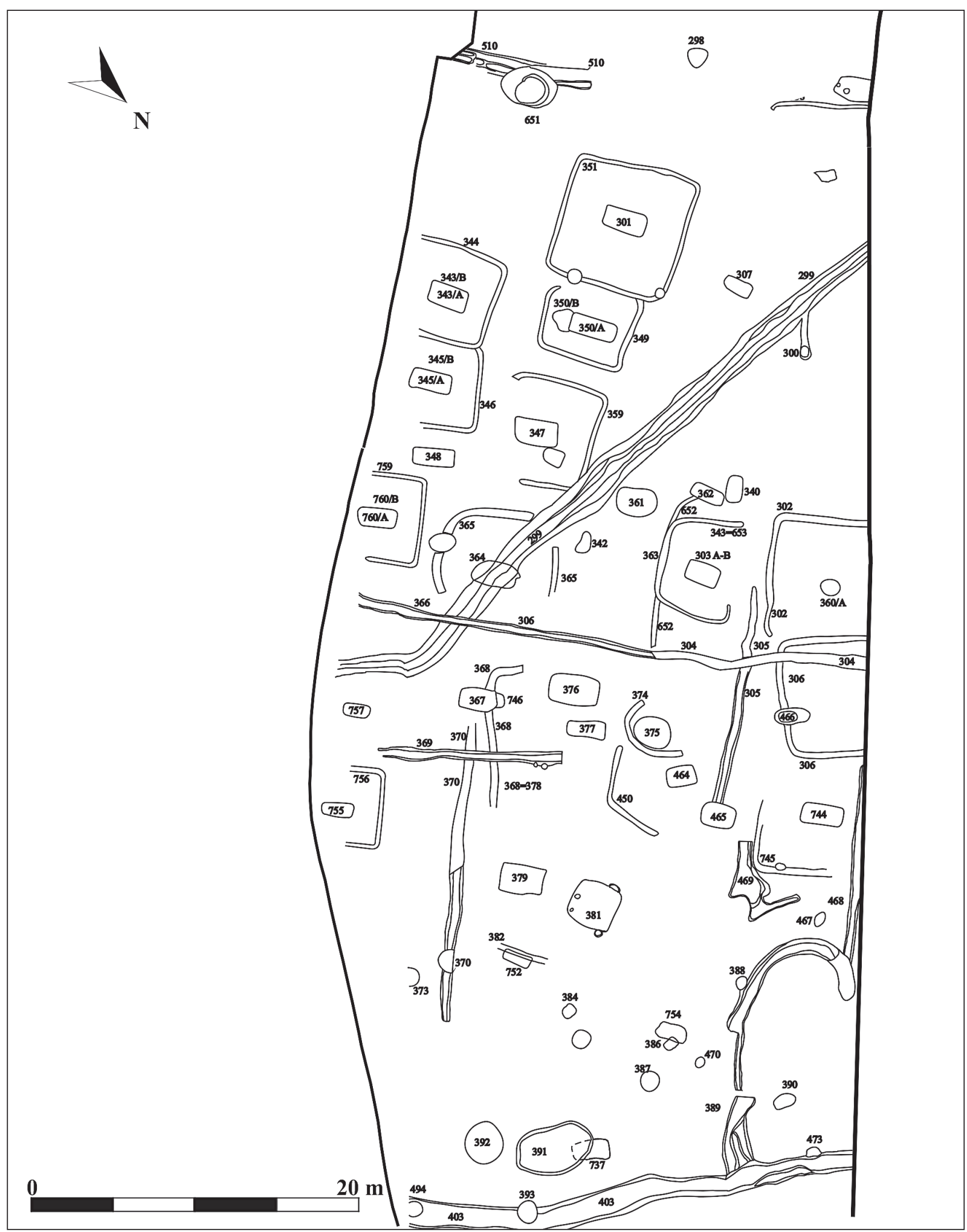

Fig. 24. Features in the territory of the Celtic cemetery 


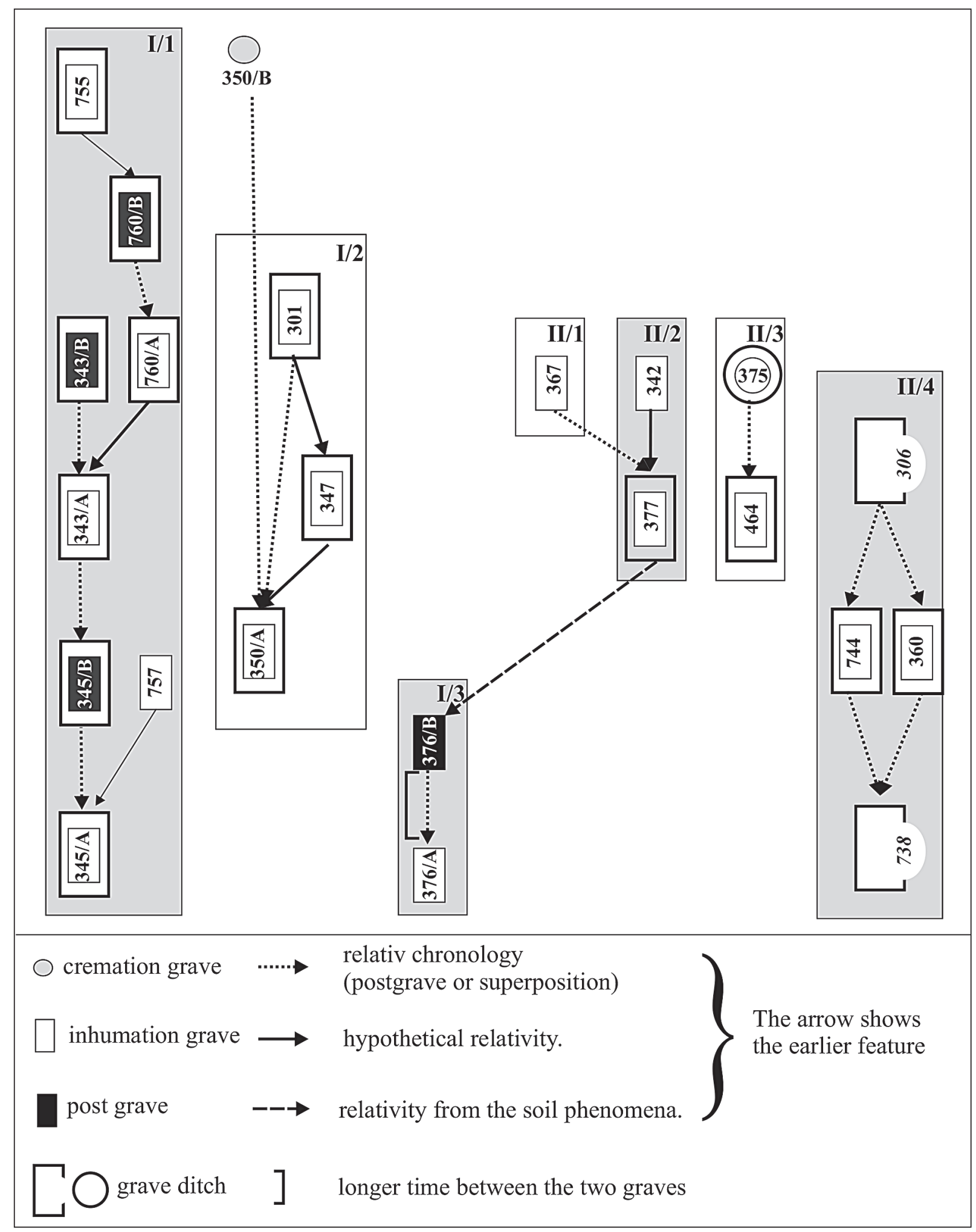

Fig. 25. Chronological position of the graves 


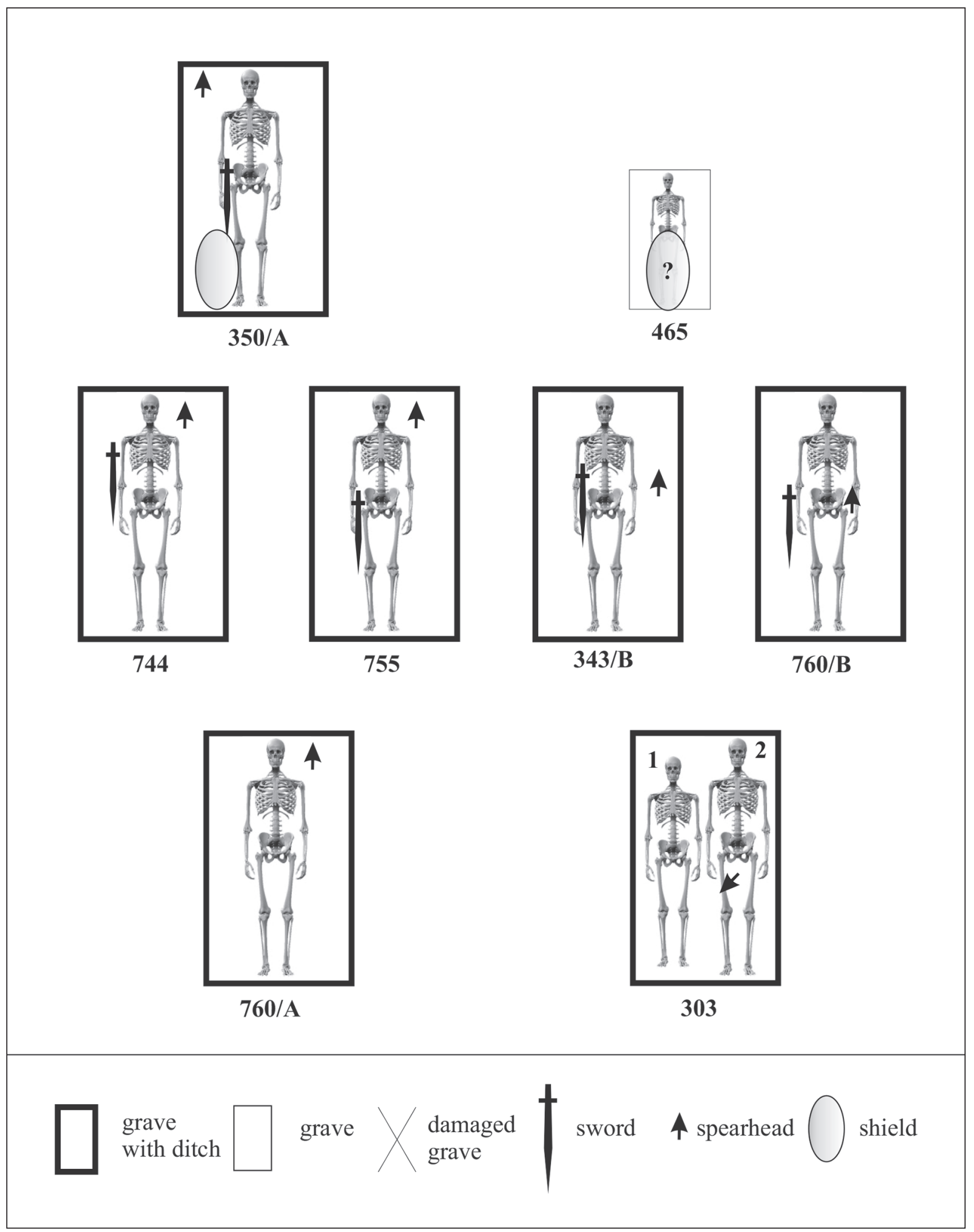

Fig. 26. Position of the weapons in the graves 


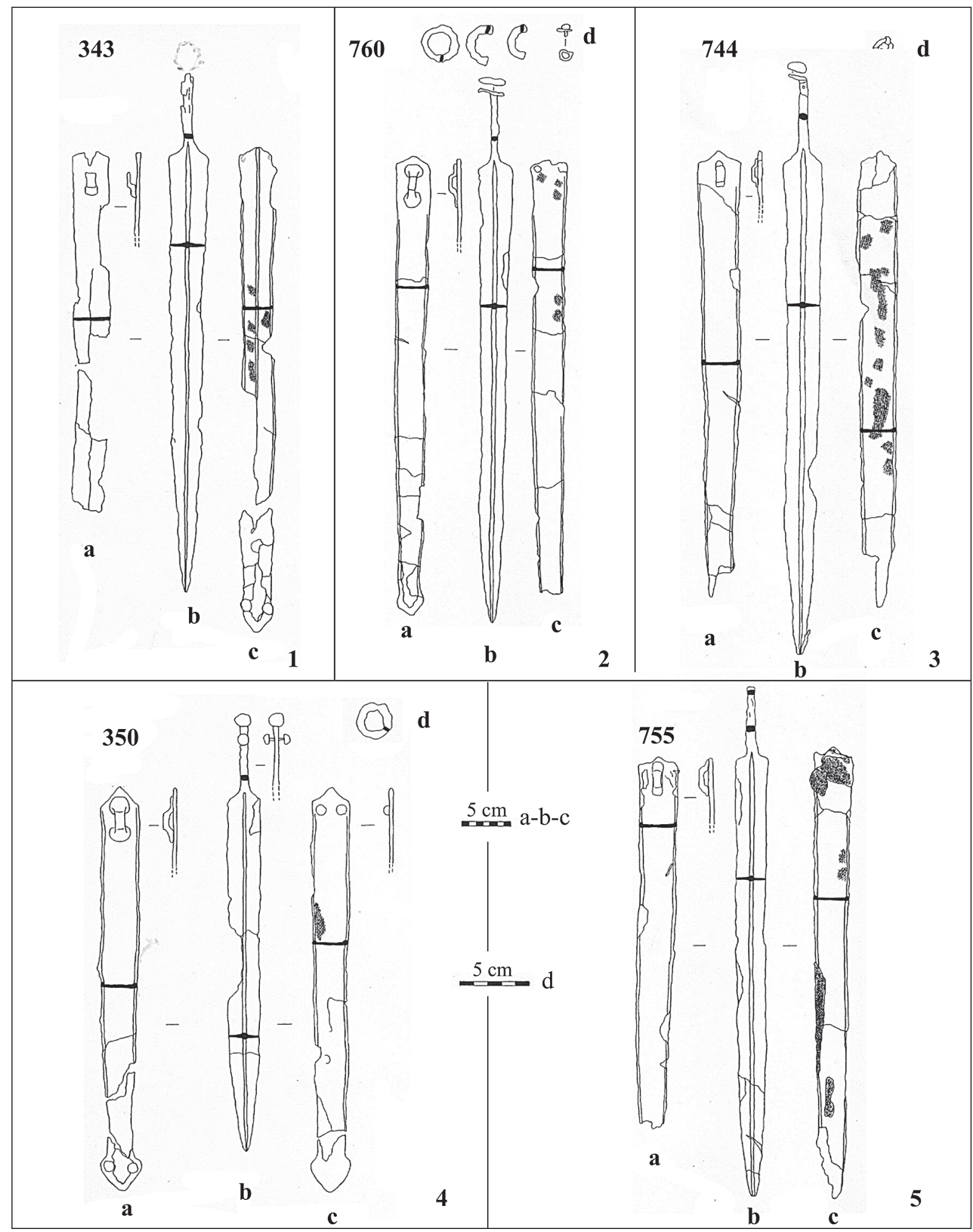

Fig. 27. The swords 


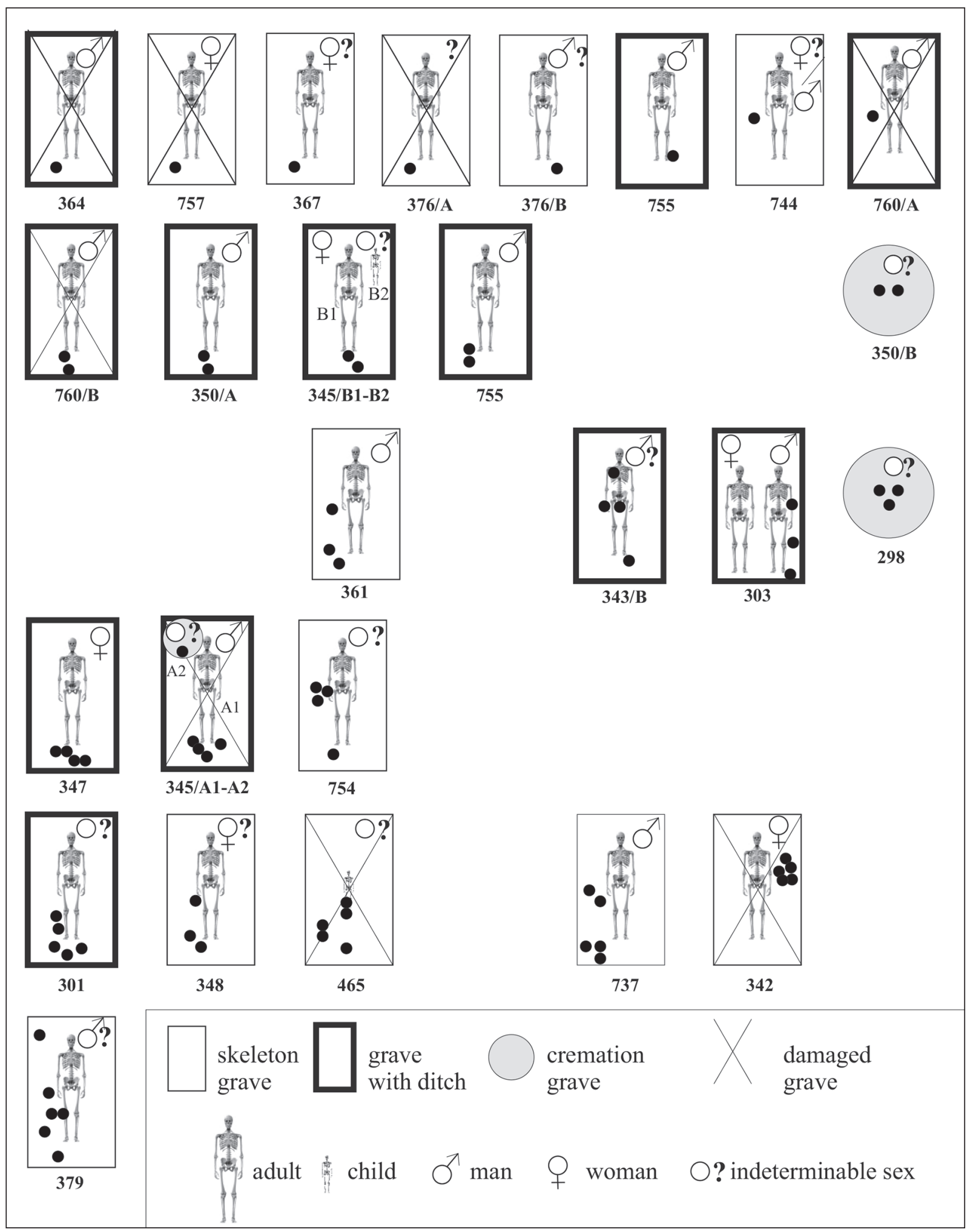

Fig. 28. Position of the vessels in the graves 


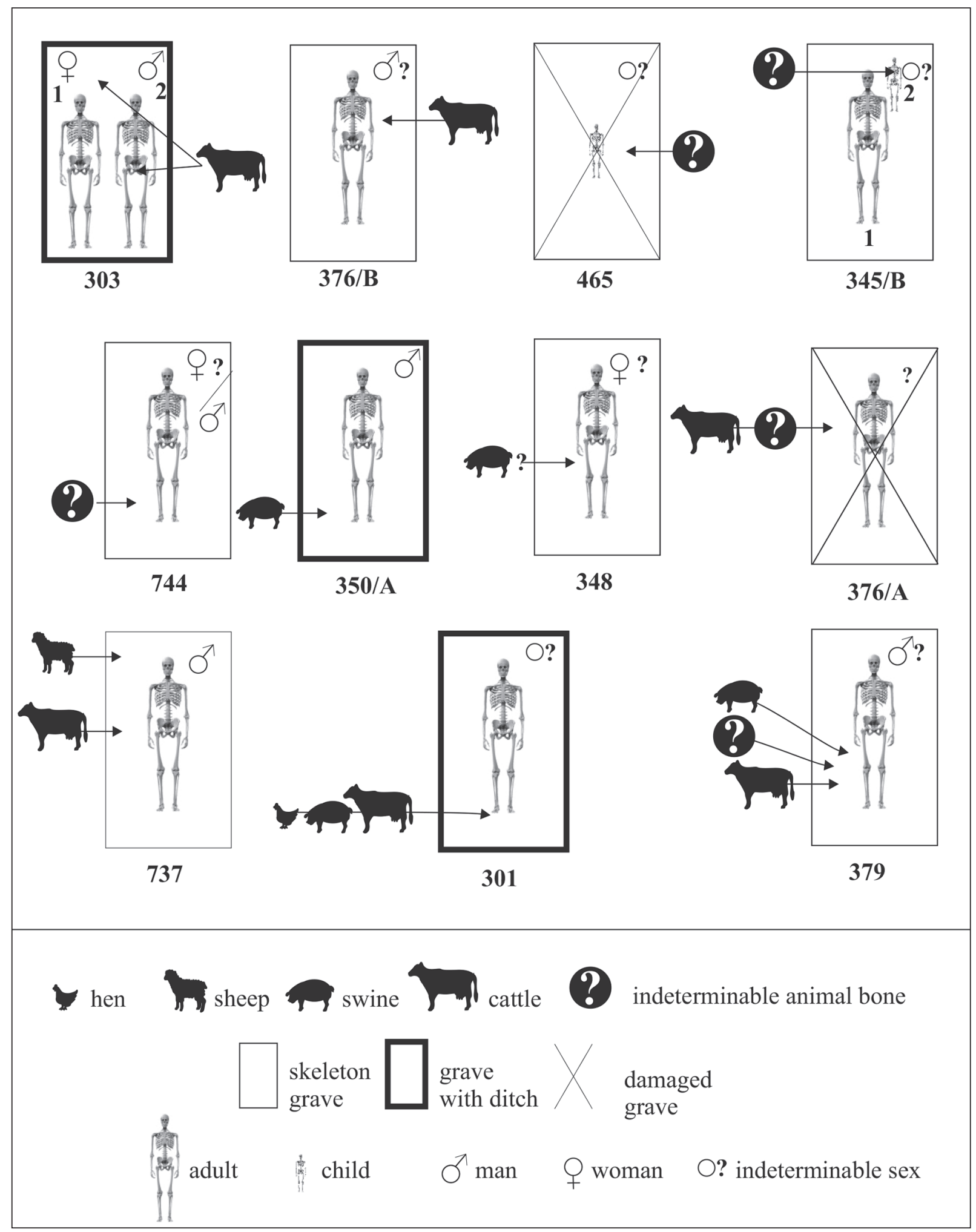

Fig. 29. Position of the animal bones in the graves 


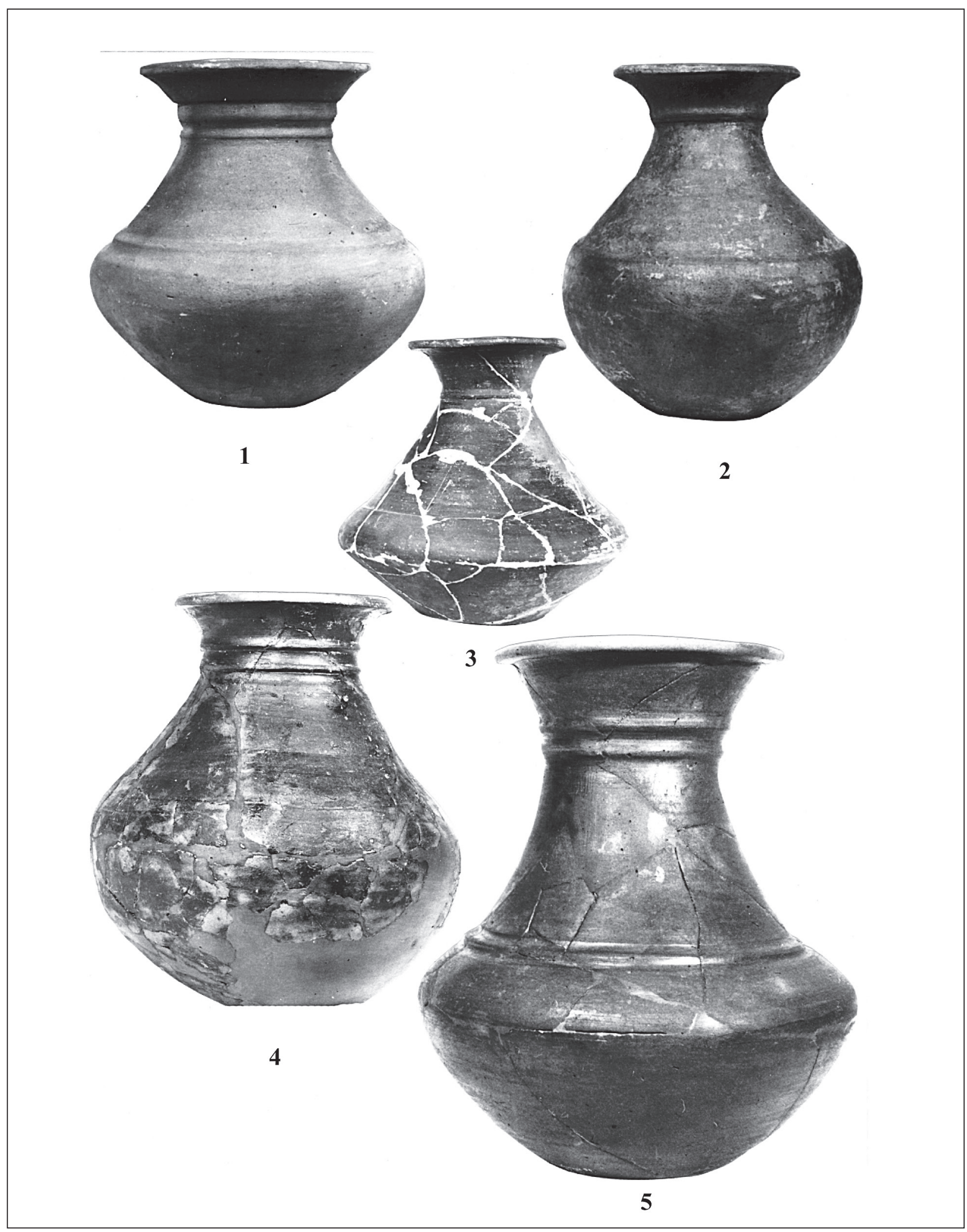

Fig. 30. 1: Grave no. 465; 2: Grave no. 350/A; 3: Grave no. 303.2; 4: Grave no. 361; 5: Grave no. 364 


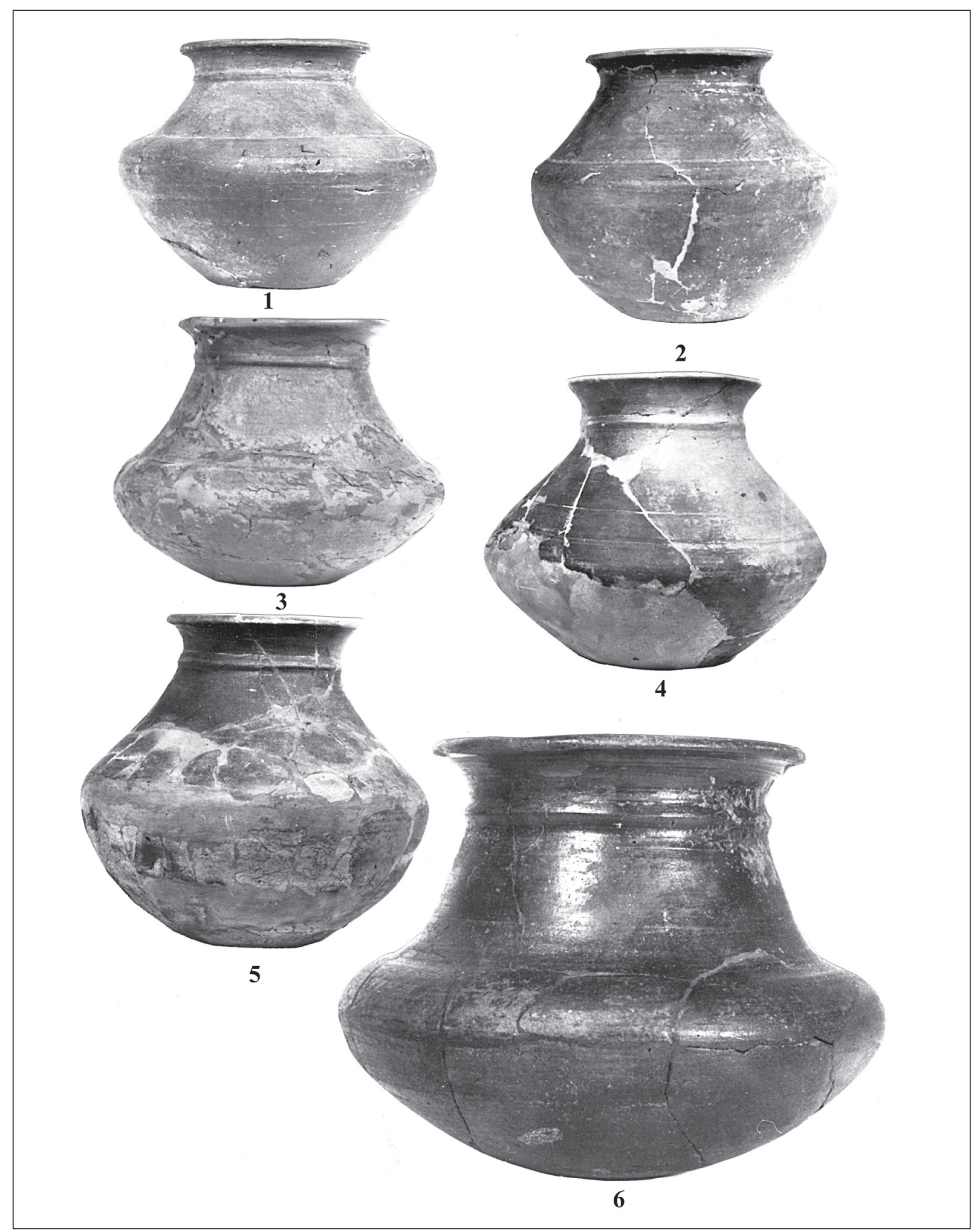

Fig. 31. 1: Grave no. 302.2; 2: Grave no. 345; 3: Grave no. 298; 4-5: Grave no. 343/B; 6: Grave no. 367 


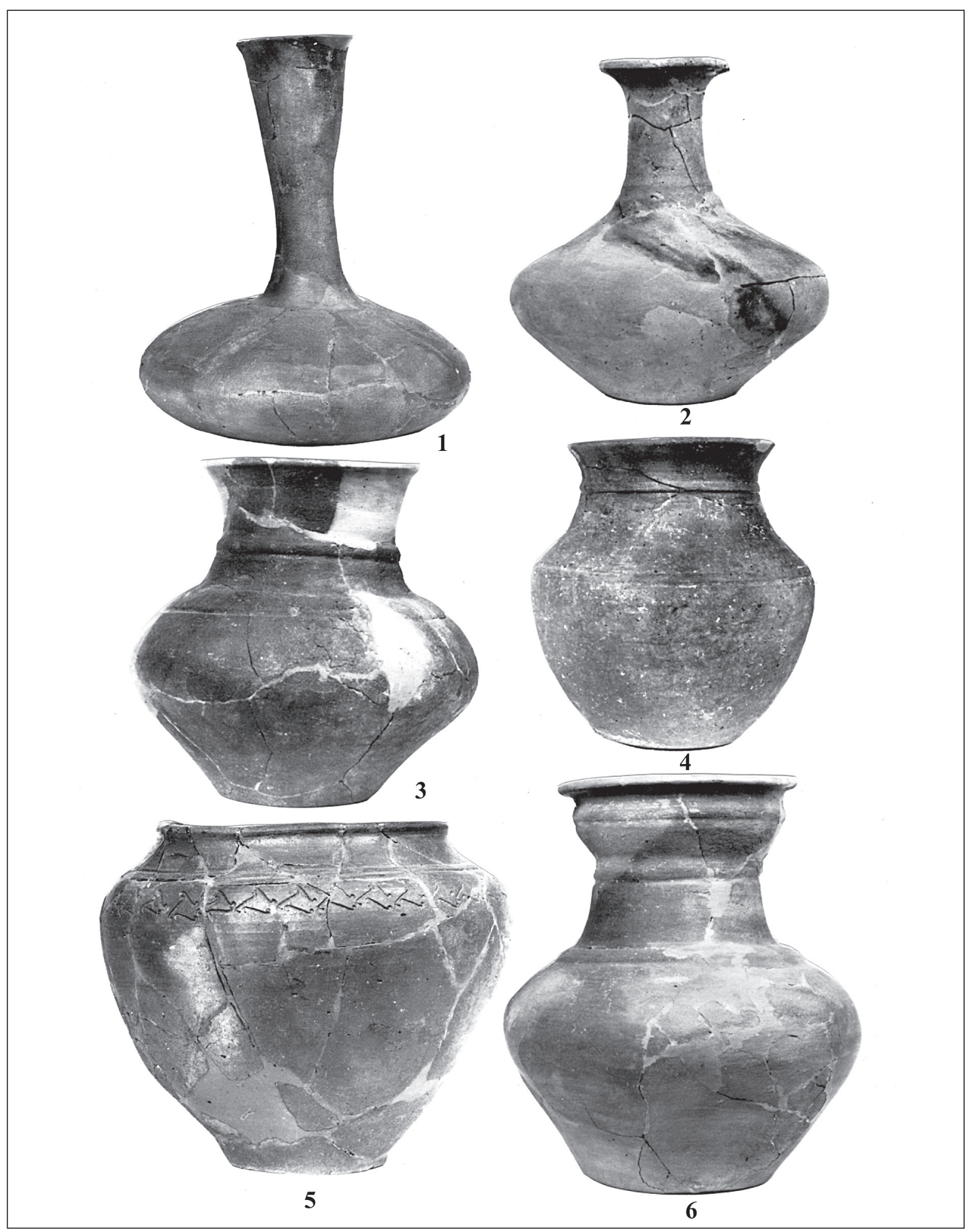

Fig. 32. 1: Grave no. 379; 2: Grave no. 342; 3: Grave no. 376/B; 4: Grave no. 379; 5: Grave no. 744 

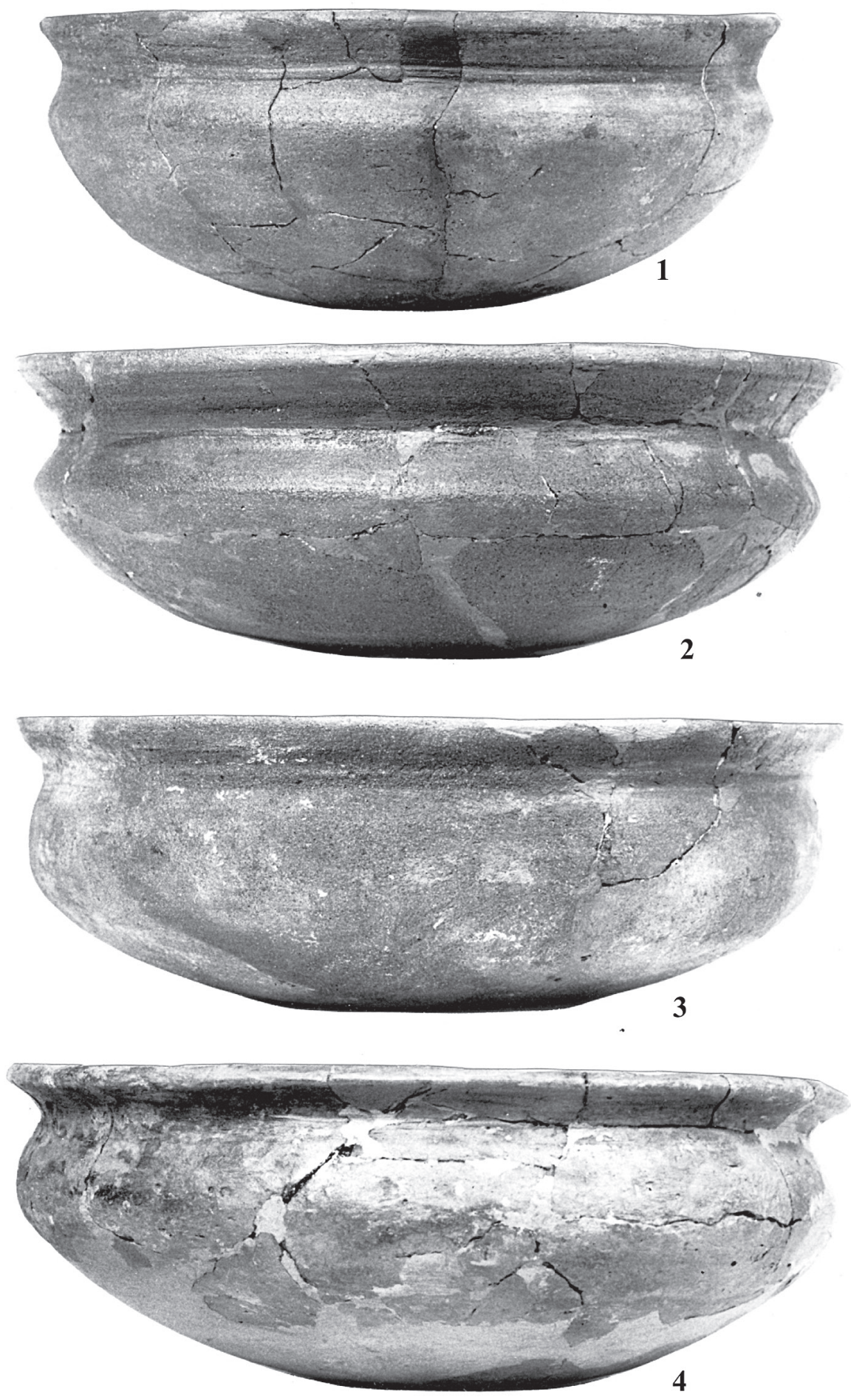

Fig. 33. 1: Grave no. 343/B; 2: Grave no. 350/A; 3: Grave no. 376/A; 4: Grave no. 379 

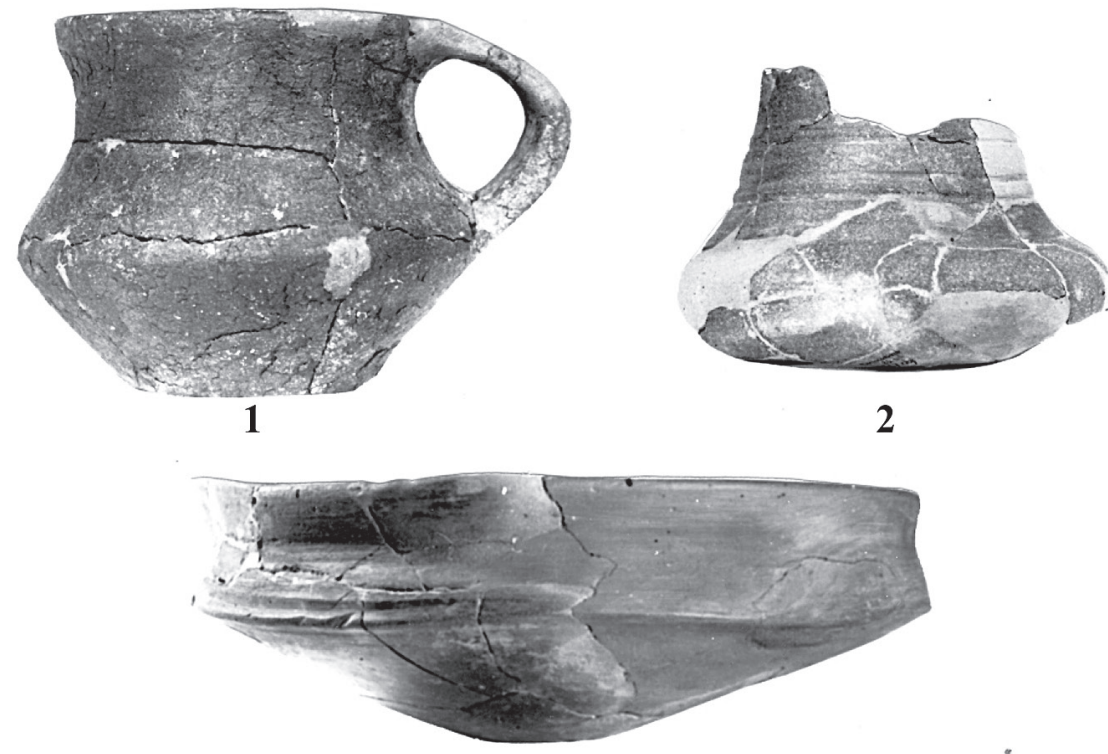

3

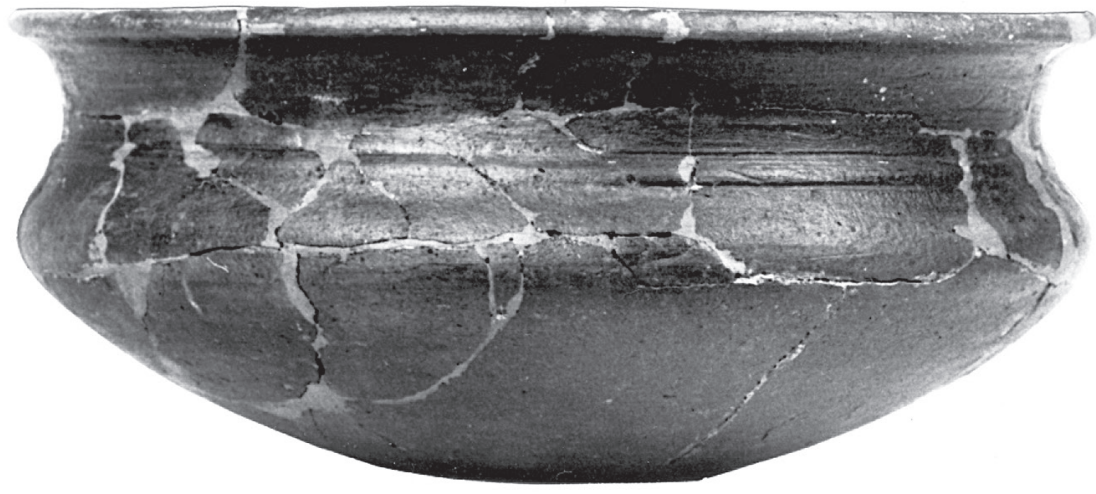

4

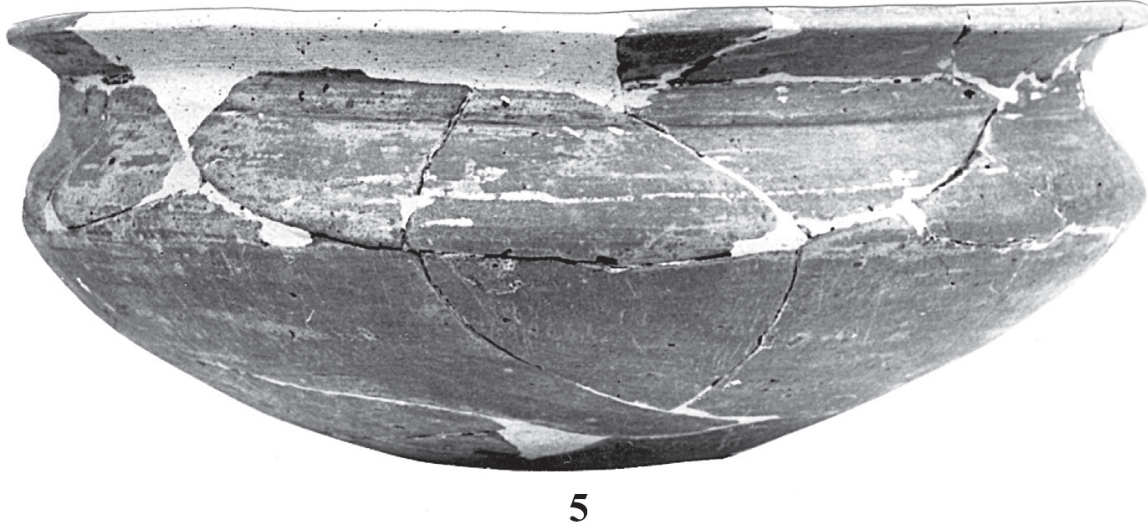

Fig. 34. 1: Grave no. 754; 2: Grave no. 757; 3: Grave no. 737; 4: Grave no. 303; 5: Grave no. 348 

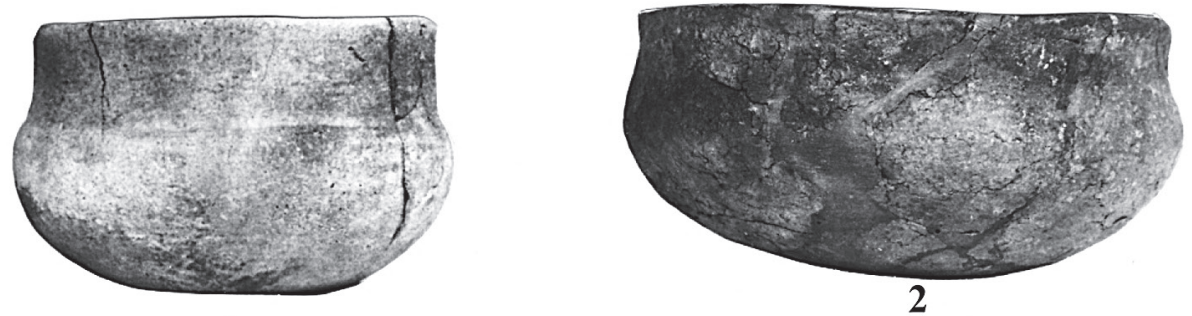

1

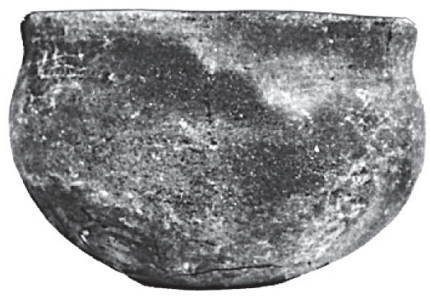

3
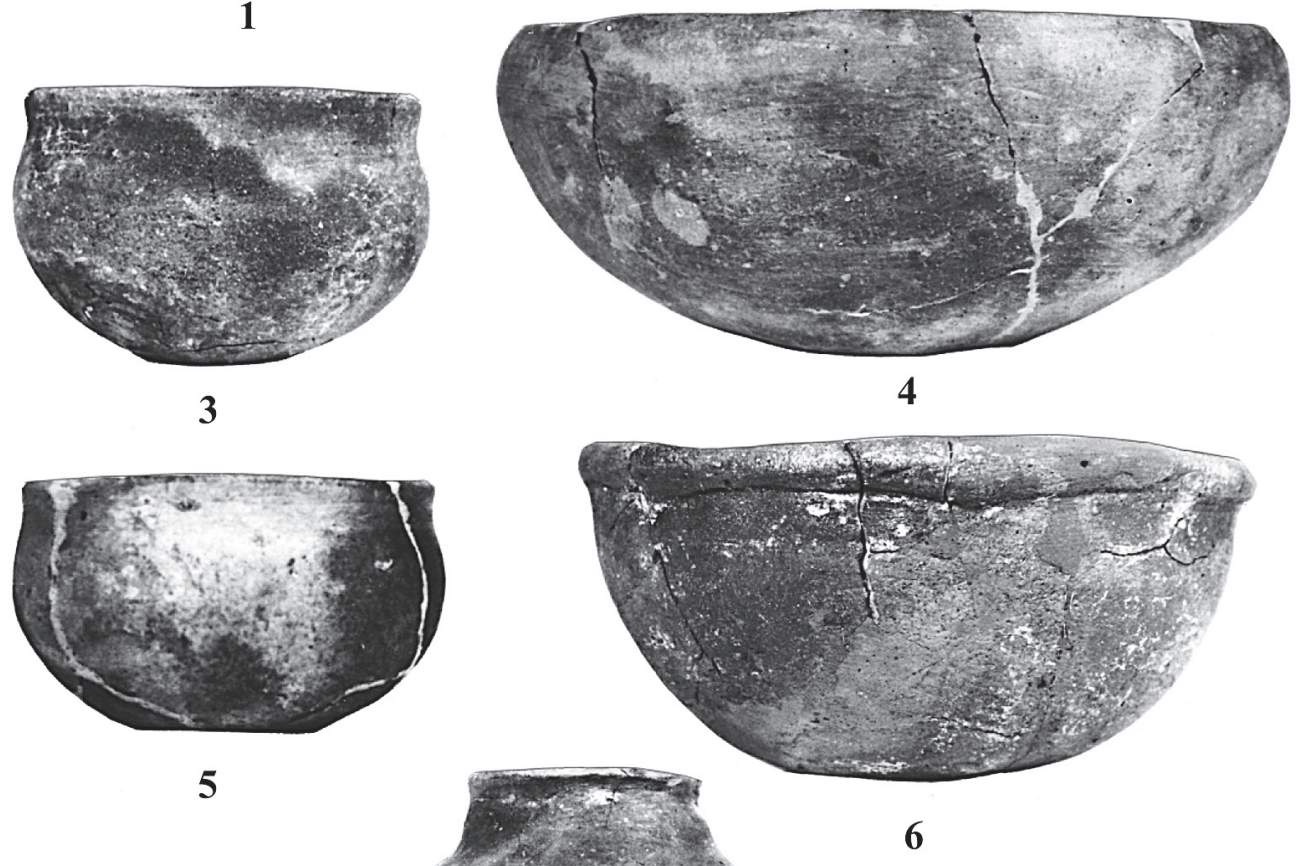

5

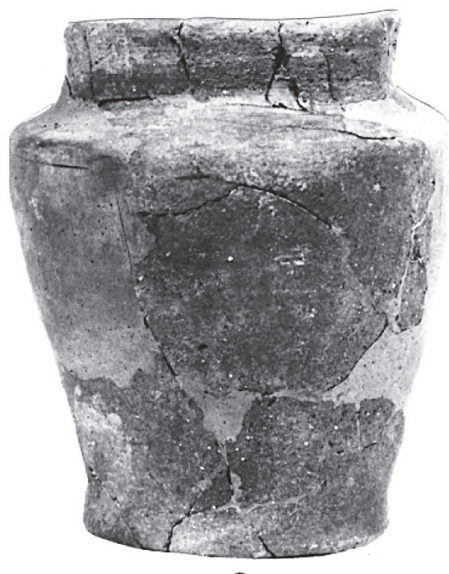

8

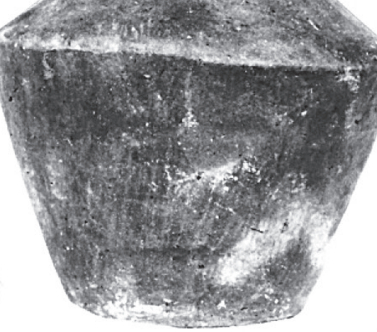

7

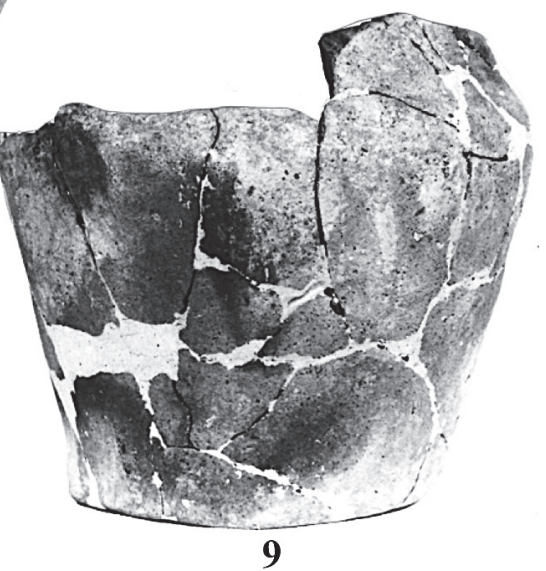

Fig. 35. 1: Grave no. 345/A2; 2: no. Grave 754; 3: Grave no. 345/A1; 4, 7: Grave no. 345/B1; 5: Grave no. 755; 6: Grave 342; 8: Grave no. 737; 9: Grave no. 348 


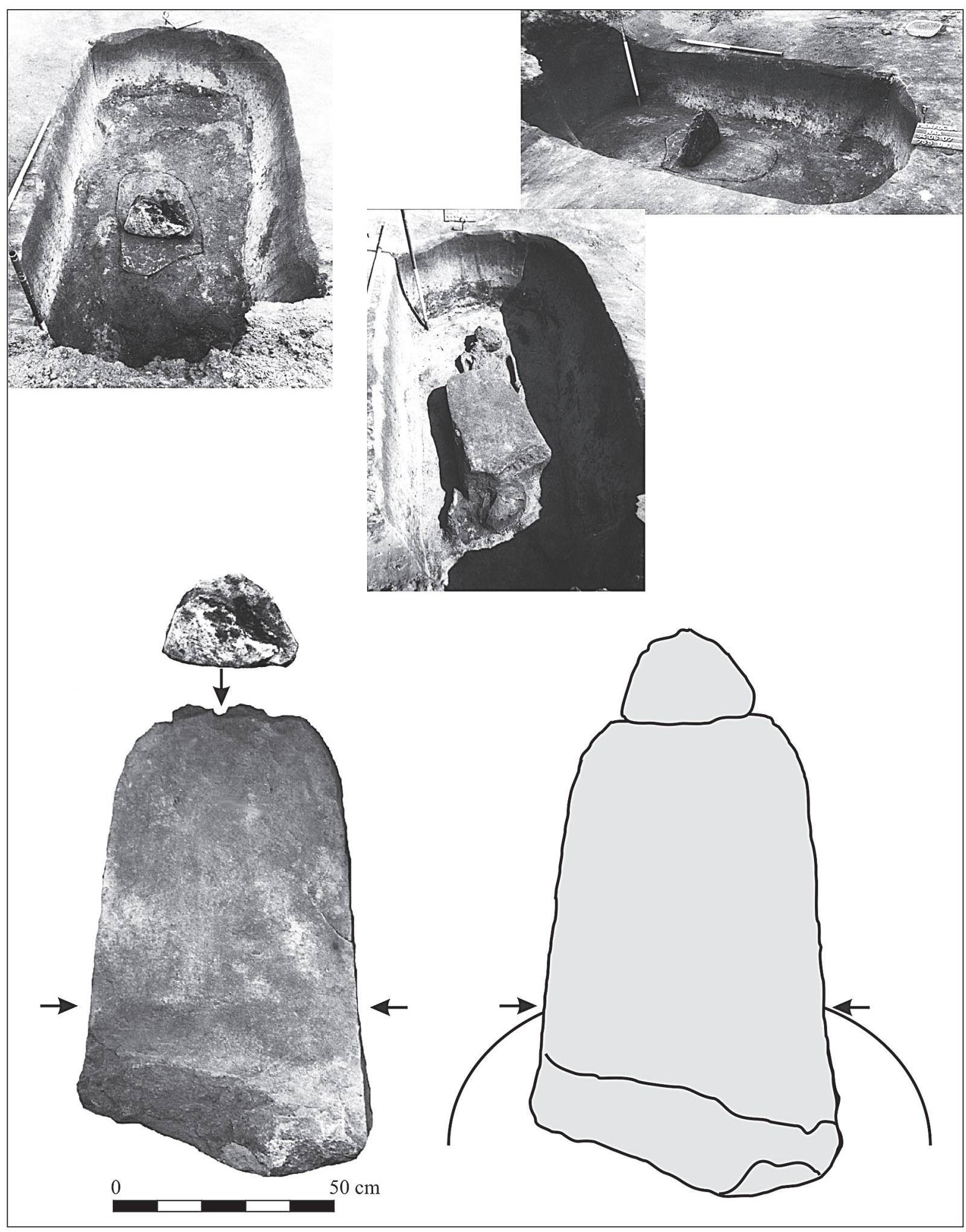

Fig. 36. Grave no. 755 


\section{REFERENCES}

BAGLEY et al. 2010

BARTÍK-Č́AMBAL 2014

Bella 1889

BELLA 1892

Bella 1894

BELTZ 1911

BENADÍK 1954

BENADÍK 1957

BENADÍK 1960

BENADÍK 1962

BENADÍK 1963

BENADIK 1983

BERECKI-VAIDA 2017

BERGER 1882

BERGMANN 1958

BINDING 1993

BLEČIĆ KaVUR-KaVuR 2010

BLEČIĆ KAVUR-KaVUR 2014

BogNÁR-KuTZIÁN 1975

BRUNAUX-RAPIN 1988

BUJNA 1989

BuJNA 1998

BujNA 2005

BuJNA-ROMSAUER 1983

ČIŽMÁŘ 1995

ČIŽMÁŘovÁ 2011

DEHN-STÖLLNER 1996
= J. M. Bagley-C. EgGL-D. Neumann-R. Schumann: Die späthallstatt-/frühlatènezeitliche Siedlung an der Haffstraße in München-Trudering. BBBD 51 (2010) 67-125.

= J. BARTÍK-R. ČAMBAL: Laténske nálezy z Tisovca-hradovej, okr. Rimavská Sobota (Latènezeitliche Funde aus Tisovec-Hradová, Bz. Rimavská Sobota). ZSNM 108, Archeológia 24 (2014) 95-102.

= L. BELLA: Újabb soproni ősleletekröl [About another prehistoric finds in Sopron]. ArchÉrt 9 (1899) 357-366.

= L. BELlA: Petőházi leletekről (Soprony m.) [About Petőházi finds (Sopron county)]. ArchÉrt 12 (1892) 346-347.

$=$ L. BELlA: Babóti leletek [Babót finds]. ArchÉrt 14 (1894) 301-305.

$=$ R. BELTZ: Die Latènefibeln. ZfE 43 (1911) 664-817.

= B. BENAdíK: Ďalší rok výskumu na latènskom pohrebisku vo Vel'kej Mení, okres Vráble [Another year of research of the La Tène cemetery at Velki Maňa, dist. Vráble]. AR (1954) 319-338

= B. BENADíK: Keltské pohrebiská na Juhozápadnom Slovensku - Keltische Gräberfelder der Südwestslowakei. ASF 1. Bratislava 1957.

= B. BENADÍK: Keltské pohrebisko v Bajči-Vlkanove (Ein keltisches Gräberfeld in Bajči-Vlkanovo). S1A 8/2 (1960) 393-435.

= B. BENADíK: Chronologické vzt’ahy keltských pohrebisk na Slovensku (The chronological relations Celtic necropolis in Slovakia). S1A 10/2 (1962) 341-396.

= B. BenAdík: Zur Frage der von chronologischen Beziehungen der keltischen Gräberfeld in der Slowakei. SlA 11 (1963) 339-383.

= B. BENADÍK: Maňa. Keltisches Gräberfeld. Fundkatalog. Materialia archaeologica Slovaca 5. Nitra 1983.

= S. BERECKI-D.-L. VAIDA: Late Iron Age double burials in the Carpathian Basin. Istros 23 (2017) 13-54.

= Š. BERGER: O nálezu bronzů ve vřídle zvaném „Riesenquelle“ u Duchcova v Čechách [About the bronze findings from a hot spring called "Riesenquelle" near Duchcov in Bohemia]. PA 12 (1882) 44-45.

= J. BeRgMANN: Entwicklung und Verbreitung der Paukenfibel. Ein Beitrag zur Späthallstatt- und Frühlatènestufe des süddeutsch-schweizerisch-ostfranzösischen Raumes. JRGZM 5 (1958) 18-93.

$=$ U. BINDING: Studien zu den figürlichen Fibeln der Frühlatènezeit. UPA 16. Bonn 1993.

= M. BleČIĆ KAVUR-B. KAVUR: Grob 22 iz beogradske nekropole Karaburma: retrospektiva i perspektiva (Grave 22 of the Belgrade necropolis in Karaburma: Retrospective and perspective). Starinar 60 (2010) 57-84.

= M. BleČIĆ KAVUR-B. KAVUR: ' ...to boldly go where no man has gone before.' Dedicated to Ruth and Vicent... In: Celtic Art in Europe. Making Connections. Essays in honour of Vincent Megaw on his $80^{\text {th }}$ birthday. Eds: Ch. Godsen, S. Crawford, K. Ulmschneider. Oxford-Philadelphia 2014, 264-273.

= I. BogÁR-Kutzián: Some new early La Tène finds in the Northern Danube Basin. Alba Regia 14 (1975) 35-46.

= J.-L. BRunAuX-A. RAPIN: Gournay II. Boucliers et lances, dépôts et trophées. Revue Archéologique de Picardie. No spéc. 1988. Paris 1988

= J. BujnA: Das latènezeitliche Gräberfeld bei Dubník. SlA 37 (1989) 245-354.

= J. BuJNA: Münsingen-Rain und die keltischen Gräberfelder im mittleren Donaugebiet. Kontakte im Spiegel des frühlatènezeitlichen Materials. In: Münsingen Rain. Ein Markstein der keltischen Archäologie. Hrsg.: F. Müller. Schriften des Bernischen Historischen Museums 2. Bern 1998, $171-203$

$=$ J. BujNA: Kruhový šperk z laténskych ženských hrobov na Slovensku (Ringschmuck aus latènezeitlichen Frauengräbern in der Slowakei). Nitra 2005.

= J. BuJnA-P. RomsauER: Späthallstatt- und frühlatènezeitliches Gräberfeld in Bučany. SlA 31 (1983) 277-324.

= M. ČIŽMÁŘ: Beitrag zur Erkenntnis der fremden Einflüsse auf dem mährischen Gebiet in der Stufe La. Tène B1. In: L'Europe celtique du V $\mathrm{V}^{\mathrm{e}}$ au III ${ }^{\mathrm{e}}$ siècle avant J.-C. Actes du deuxième symposium international d'Hautvillers (8-10 octobre 1992). Éd.: J.-J. Charpy. Mémoires de la Société Archéologique Champenoise 9. Sceaux 1995, 69-75.

= J. ČIŽMÁŘovÁ: Keltská pohřebiště na Moravě okresy Brno-město a Brno-venkov (Keltische Gräberfelder in Mähren Bezirke Brno-město und Brno-venkov). Brno 2011.

= W. Dehn-T. StÖLlnER: Fußpaukenfibel und Drahtfibel. (Marzabottofibel). Ein Beitrag zum kulturhistorischen. Verständnis des 5. Jh. in Mitteleuropa. In: Europa celtica. Untersuchungen zur 
DuLĘBA 2014

DulĘBA 2019

ĎURKOVIČ 2015

EGRY 2007

FIALA 1899

FREY 1991

FREY 1996

GARDELKOVÁ-VRTELOVÁ 2016

GÁTI 2009

GIESSLER-KRAFT 1944

GUGGISBERG-STÖLLNER 1996

GUŠTIN 1982

HELL 1936

HELLEBRANDT 1999

HoDSON 1968

HodsON 1998

HOLODŇÁK-WALDHAUSER 1984

HoRVÁtH 1987

HoRVÁTH 2016

HoRVÁtH 2017

HORVÁTH 2018
Hallstatt- und Latènekultur. Festschrift Wolfgang Dehn zum Geburtstag. Hrsg.: T. Stöllner. Veröffentlichungen des vorgeschichtlichen Seminars Marburg 12. Espelkamp 1996, 1-54.

$=$ P. DulĘBA: Results of a surface survey carried out in Nieprowice, site 5, Pińczów district in 20072009. SprawA 66 (2014) 315-358.

= P. DulęBA: On the origin of the La Tène culture in Silesia. In: Die frühe Eisenzeit in Mitteleuropa - Early Iron Age in Central Europe. Internationale Tagung vom 20.-22. Juli 2017 in Nürnberg. Hrsg.: C. Bockisch-Bräuer, B. Mühldorfer, M. Schönfelder. Beiträge zur Vorgeschichte Nordostbayerns 9. Nürnberg 2019, 369-391.

= É. Ďurkovič: Structure of the Early Iron Age settlement excavated at Győr-Ménfőcsanak. In: Studia archaeologica Nicolae Szabó LXXV annos nato dedicata. Eds: L. Borhy, K. Tankó, K. Dévai. Budapest 2015, 113-148.

= I. EGRY: Előzetes beszámoló a Győr-Ménfőcsanak, Eperföldeken végzett megelőző feltárásról (2005-2006) - Preliminary report on the investment-led excavation at Győr-Ménfőcsanak, Eperföldek (2005-2006). In: Régészeti kutatások Magyarországon - Archaeological Investigations in Hungary 2006. Ed.: J. Kisfaludi. Budapest 2007, 27-52.

$=$ F. FIALA: Das Flachgräberfeld und die prähistorische Ansiedlung in Sanskimost. Wissenschaftliche Mitteilungen aus Bosnien und der Herzegowina 6 (1899) 62-128.

= O.-H. FREY: Einige Bemerkungen zu durchbrochenen Frühlatènegürtelhaken. In: Studien zur Eisenzeit im Hunsrück-Nahe-Raum. Symposium Birkenfeld 1987. Hrsg.: A. Haffner, A. Miron. TrZ Beiheft 1. Trier 1991, 101-111.

= O.-H. FrEY: Bemerkungen zu einigen Fundstücken der Frühlatenezeit aus Niederösterreich. In: Die Kelten in den Alpen und an der Donau. Akten des Internationalen Symposiums St.Pölten, 14.-18. Oktober 1992. Hrsg.: E. Jerem, A. Krenn-Leeb, J.-W. Neugebauer, O.-H. Urban. Archaeolingua: Studien zur Eisenzeit im Ostalpenraum 1. Budapest-Wien 1996, 193-215.

= A. GARDELKOVÁ-VRTELOVÁ: Pokus o rekonstrukci pochvy meče z hrobu $46 \mathrm{z}$ laténského pohřebiště v Palárikově (Attempt to reconstruct the scabbard from the grave 46 from the La Tène cemeteries in Palárikovo). ŠtZ 60 (2016) 149-156.

= Cs. GÁtı: A szajki (Baranya megye) koravaskori telep kulturális kapcsolatai (Cultural contacts of the Early Iron Age settlement at Szajk (Baranya County). In: M $\Omega$ MO $\Sigma$ VI. Őskoros Kutatók VI. Összejövetelének konferenciakötete. Nyersanyagok és kereskedelem. Köszeg, 2009. március 1921. Ed.: G. Ilon. Szombathely 2009, 65-77.

$=$ R. GIESSLER-G. KRAFT: Untersuchungen zu frühen und älteren Latènezeit am Oberrhein und in der Schweiz. BRGK 32 (1942) [1944] 20-116.

= M. GugGisberG-Th. StÖLlner: Ein „Herr der Tiere“ im südlichen Ostalpenraum? Bemerkungen zur frühlatènezeitlichen Stellung einiger Neufunde aus dem Führholz bei Völkermarkt/Kärnten. In: Europa celtica. Untersuchungen zur Hallstatt- und Latènekultur. Hrsg.: Th. Stöllner. Veröffentlichungen des vorgeschichtlichen Seminars Marburg 12. Marburg/Espelkamp 1996, 117-152.

= M. GušTiN: Zeitliche Einordnung der verzierten keltischen Schwerter aus Jugoslawien. L'art Celtique de la pèriode d'expansion, $\mathrm{IV}^{\mathrm{e}}$ et $\mathrm{III}^{\mathrm{e}}$ siècles avant notre ère. Eds.: P.-M. Duval, V. Kruta. Paris 1982, 191-202.

= M. Hell: Wohnstättenfunde der Mittellatènezeit aus Salzburg. WPZ 13 (1936) 42-72.

= M. Hellebrandt: Celtic finds from Northern Hungary. Corpus of Celtic Finds in Hungary. 3.: Eds.: T. Kovács, É. Petres, M. Szabó. Budapest 1999.

= F. R. Hodson: The La Tène Cemetery at Münsingen Rain. Acta Bernensia 5. Bern 1968.

$=$ F. R. Hodson: Reflections on Münsingen-Rain with a note on »Münsingen Fibulae«. In: Münsingen Rain. Ein Markstein der keltischen Archäologie. Hrsg.: F. Müller: Schriften des Bernischen Historischen Museums 2. Bern 1998, 29-36.

= P. HoLODŇÁK-J. WALDAHUSER: Předduchcovský horizont (fáze LT.B1a) v Čechách (Der Vorduxer Horizont (Phase LT.B1a) in Böhmen). AR 36 (1984) 31-48.

= L. HoRvÁth: The surroundings of Keszthely. In: Corpus of Celtic Finds in Hungary. I.: Transdanubia 1. Eds.: T. Kovács, F. É. Petres, M. Szabó. Budapest 1987, 63-178.

= A. Horváth M.: Problems about the change of periods and rites in the La Tène cemetery on Csepel Island (Budapest). In: Iron Age Chronology in the Carpathian Basin. Proceedings of the International Colloquium from Târgu Mureş, 8-10 October 2015. Ed.: S. Berecki. Bibliotheca Mvsei Marisiensis 5. Cluj-Napoca 2016, 141-163.

= A. HoRvÁth M.: Beads and birds. Special finds from the La Tène cemetery at Csepel Island. BudRég 50 (2017) 53-68.

= A. Horváth M.: Connectivities in the Celtic cemetery of Csepel Island. In: Iron Age Connectivity in the Carpathian Basin. Proceedings of the International Colloquium from Târgu Mureş, 13-15. October 2017. Ed.: S. Berecki. Bibliotheca Mvsei Marisiensis 5. Cluj-Napoca 2018, 65-77. 
HORVÁTH 2019

= A. Horváth M.: Sárkányok és madarak népe - A Csepel-sziget keltái - People of Birds and Dragons. The Celts of Csepel Island. Temporary exhibition in the Aquincum Museum of the Budapest History Museum, $26^{\text {th }}$ April 2019-31 ${ }^{\text {st }}$ October 2019. Exhibition catalogue. Budapest 2019.

Horváth-Gardelková-Vrtelová 2015 = P. Horváth-A. GardelkovÁ-VRTElová: Rekonstrukce hrobu bojovníka z Palárikova (Reconstruction of the warrior grave from Palárikovo). Živá Archeologie 17 (2015) 15-19.

HUNYADY 1944

HUNYADY 1957

JACOBSTHAL 1944

JEREM 1968

JEREM 1976

JEREM 1984

JEREM 1996

JUD 2009

KAENEL 1990

KAPPEL 1969

KARWOWSKI-CZUBAK 2019

KOVÁCS-RACZKY 1999

KRÄMER 1964

KRUTA 1971

KRUTA 1979

KRUTA 1986

KRUTA 2000

KRUTA 2014

KYSELA-VENCLOVÁ 2019

LEJARS 2008

LJUBIĆ 1889

LOVAS 1939

MARÓTI-KECSKÉS 2008

MÁRTON 1933

MÁRTON 1934
= I. HunYADY: Kelták a Kárpát medencében - Die Kelten im Karpatenbecken. DissPann II.18. Budapest 1942-1944

= I. HuNYADY: Kelták a Kárpát medencében. Leletanyag [Celts in the Carpathian Basin. The archaeological finds]. RégFüz 2. Budapest 1957.

= P. JACOBSTHAL: Early Celtic Art. Oxford 1944.

= E. JEREM: The Late Iron Age cemetery of Szentlörinc. ActaArchHung 20 (1968) 159-208.

= E. JEREM: Stempelverziertes frühlatenezeitliches Gefäss aus Écs. MittArchInst 5 (1974-75) [1976] 45-57.

= E. JEREM: An early Celtic pottery workshop in North Western Hungary: some archaeological and technical evidence. OJA 3 (1984) 57-80.

$=$ E. JEREM: Zur ethnogenese der Ostkelten - Späthallstatt- und frühlatenezeitliche Gräberfelder zwischen Traisental und Donauknie. In: Die Kelten in den Alpen und an der Donau. Akten des Internationalen Symposiums St.Pölten, 14.-18. Oktober 1992. Hrsg.: E. Jerem, A. Krenn-Leeb, J.-W. Neugebauer, O.-H. Urban. Archaeolingua : Studien zur Eisenzeit im Ostalpenraum 1. BudapestWien, 1996, 91-110.

= P. JuD: Die latènezeitlichen Gräber von Gumefens. Cahiers d'Archéologie Fribourgeoise / Freiburger Hefte für Archäologie 11 (2009) 56-108.

= G. KAENEL: Recherches sur la période de la Tène en Suisse occidentale. Cahiers d'archéologie romande 50. Lausanne 1990

= I. KAPPEL: Die Graphittonkeramik von Manching. Die Ausgrabungen in Manching 2. Wiesbaden 1969.

= M. Karwowski-J. M. CzubaK: Das latènezeitliche Gräberfeld von Göttlesbrunn, Flur Geitzbilln (VF 07-08). In: Beiträge zum Tag der Niederösterreichischen Landesarchäologie 2019. Hrsg. F. Pieler, P. Trebsche. Asparn/Zaya 2019, 71-78.

$=$ T. KovÁCS-P. RACZKY (Hrsg.): Prähistorische Goldschätze aus dem Ungarischen Nationalmuseum. Ausstellung im Museum für Vor- und Frühgeschichte Archäologisches Museum Frankfurt am Main 16.10.1999-9.1.2000. Budapest 1999.

= W. KRÄMER: Das keltische Gräberfeld von Nebringen. Stuttgart 1964.

= V. KRUTA: Le trèsor de Duchov dans les collections tchèhoslovakques. Usti nad Labem 1971.

= V. KRUTA: Duchcov-Münsingen : nature et diffusion d'une phase laténienne. In: Les mouvements celtiques du V $\mathrm{V}^{\mathrm{e}}$ au $\mathrm{I}^{\mathrm{er}}$ siècle avant notre ère. Actes du XXVIII ${ }^{\mathrm{e}}$ colloque organisé à l'occasion du IX Congrès International des Sciences Préhistoriques et Protohistoriques, Nice, 19 septembre 1976, CNRS. Éd.: P.-M. Duval, V. Kruta. Paris 1979, 81-115.

$=$ V. KRUTA: Le Corail, le vin et l'arbre de vie: observations sur l'art et la religion des Celtes du $\mathrm{V}^{\mathrm{e}}$ au $1^{\text {er }}$ siècle avant J.-C. EC 23 (1986) 7-32.

= V. KRUTA: Les Celtes: histoire et dictionnaire. Paris 2000.

= V. KRUTA: Esses et palmettes: la fibule de Marefy (ex Bučovice) dans son contexte européen. In: Moravské křižovatky. Střední Podunají mezi pravěkem a historií. Věnováno památce Miloše Čižmáře. Ed.: J. Čižmářová, N. Venclová, G. Březinová. Brno 2014, 691-698.

$=\mathrm{J}$. Kysela-N. Venclová: The spiritual wold. In: The Celts. Bohemia from the $8^{\text {th }}$ Century to the $1^{\text {st }}$ Century BC. Eds.: J. Militký, J. Kysela, M. Tisucká. Prague 2019, 125-140.

$=$ TH. LeJARs: Les guerriers et l'armement celto-italique de la nécropole de Monte Bibele. In: Tra mondo celtico e mondo italico. La necropoli di Monte Bibele. Atti della Tavola Rotonda, Roma 1997. Ed.: D. Vitali, S. Verger. Bologna 2008, 127-222.

= S. LJubić: Popis arkeologičkoga odjela Nar. zem. muzeja u Zagrebu. Odsjek I.1.: Egipatska sbirkapredhistorička sbirka [Description of the Archaeological Department of Natonal Museum in Zagreb. Egyptian collection-Prehistoric collection]. Zagreb 1889.

= E. LovAs: Kelta leletek a győri Kálváriai és újszállási temetőkből és Rábatamásiból (Keltische Funde aus Győr und Rábatamási). FolArch 1-2 (1939) 88-96.

= É. MARÓtI-A. KeCSKÉS: Kelta temető Solymáron [Celtic cemetery in Solymár]. In: Képek a múltból. Az elmúlt évek ásatásaiból Pest megyében. Eds: M. Gyöngyössy, K. Ottományi. Szentendre 2008, 55 .

= L. MÁRTON: A korai La Tène kultúra Magyarországon. Die Frühlatènezeit in Ungarn. ArchHung 11. Budapest 1933.

= L. MÁRTON: A korai La Tène sírok leletanyaga (Das Fundinventar der Frühlatene-Gräber). DolgSzeged 9-10 (1933-1934) 93-127. 
Meduna 1965

Megaw-Megaw 2001

MIRCHEVA 2007

MÖLLER 2000

Moosleitner-Pauli-PenNinger 1974

Moser et al. 2012

MÜLLER 1998

NEBEHAY 1971

NEBEHAy 1973

NEBEHAY 1993

NÉMETI 1992

Neugebauer 1992

Neugebauer 1996

PARE 2012

PAUli 1978

PENNINGER 1972

Petres-SZabó 1986

PoPOVIĆ 1996

RAMSL 2002

RAMSL 2003

RAMSL 2011

RAPIN 1999

ROUALET 1991

Rustoiu 2008

RUSTOIU 2012

RUSTOIU 2015
= J. MEDUNA: Příspěvek k otázce počátku pohřbívání na plochých keltských pohřebištích na Moravě (Zur Frage der ersten Bestattungen auf den keltischen Flachgräberfeldern in Mähren). AR 17 (1965) 795-825.

= M. R. Megaw-J. V. S. Megaw: Celtic Art, from its Beginnings to the Book of Kells. London 2001.

= E. MirChEVA: La Tène C fibulae kept in Varna Archaeological Museum. In: The Lower Danube in Antiquity (VI c. BC - VI c. AD). International Archaeological Conference, 6-7, 10. 2005, BulgariaTutrakan. Ed.: L. F. Vagalinski. (Sofia 2007, 65-72

= CH. MöLLER: Das Grab 13 von Leimersheim (Pfalz). Ein Beitrag zur Chronologie der Frühlatènezeit. AKorr 30 (2000) 409-428.

= F. Moosleitner-L. Pauli-E. Penninger: Der Dürrnberg bei Hallein. II.: Katalog der Grabfunde aus der Hallstatt- und Latènezeit. MBV 17. München 1974.

= S. Moser-G. Tiefengraber-K. WiltschKe-Schrotta: Der Dürrnberg bei Hallein. Die Gräbergruppen Kammelhöhe und Sonneben. Dürrneberg-Forschungen 5. Rahden/Westfalen 2012.

= F. MüLLER: Die Entwicklung des Waldalgesheimstils in Münsingen-Rain. In: Münsingen Rain. Ein Markstein der keltischen Archäologie. Hrsg.: F. Müller. Schriften des Bernischen Historischen Museums 2. Bern 1998, 71-83.

= S. NeBeHAY: Das latènezeitliche Gräberfeld von der Flur Mühlbacher bei Au am Leithagebirge, p. B. Bruck a. d. Leitha, N.Ö. ArchA 50 (1971) 138-175.

$=\mathrm{S}$. NEBEHAY: Das Latènezeitliche Gräberfeld von der Kleinen Hutweide bei Au am Leithagebirge, p. B. Bruck a. d. Leitha, N.Ö. ArchA 11 (1973) 1-80.

$=$ S. NeBEHAY: Latènegräber in Niederösterreich. Kleine Schriften aus dem Vorgeschichtlichen Seminar Marburg 41. Marburg 1993.

= I. NÉMETI: Necropola Latène de la Pişcolt, judeţul Satu Mare (III) (Das latènezeitliche Gräberfeld von Pişcolt, Kr. Satu Mare). Thraco Dacica 13 (1992) 59-112.

= J. W. Neugebauer: Die Kelten im Osten Österreichs. Wissenschaftliche Schriftenreihe Niederösterreich 92-94. St. Pölten-Wien 1992.

= J. W. NeugebaueR: Eine frühlatenezeitliche Gräbergruppe in Inzersdorf ob der Traisen, N.Ö. In: Die Kelten in den Alpen und an der Donau. Akten des Internationalen Symposiums St.Pölten, 14.-18. Oktober 1992. Hrsg.: E. Jerem, A. Krenn-Leeb, J.-W. Neugebauer, O.-H. Urban. Archaeolingua : Studien zur Eisenzeit im Ostalpenraum 1. Budapest-Wien 1996, 111-178.

= CH. PARE: Grabstele. In: Lexikon zur Keltischen Archäologie. Hrsg.: S. Sievers, H. O. Urban, P. C. Ramsl. MPK 73. Wien 2012, 682-684.

= L. PAUli: Der Dürrnberg bei Hallein. III.: Auswertung der Grabfunde. Münchener Beiträge zur Vor- und Frühgeschichte 18. München 1978.

= E. PenNinger: Der Dürrnberg bei Hallein. I.: Katalog der Grabfunde aus der Hallstatt und Latènezeit. Münchner Beiträge zur Vor- und Frühgeschichte 16. München 1972.

= É. F. Petres-M. Szabó: Notes on the so-called Hatvan-boldog type scabbards. In: Actes du VIII ${ }^{\mathrm{e}}$ Colloque sur les âges du Fer en France non Mediterranéenne, Angoulême, 18-19-20 mai 1984. Ed.:

A. Duval, J. Gomez de Soto. Aquitania Supplément 1. Bordeaux 1986, 257-272.

= P. Popović: Early La Tène between Pannonia and the Balkans. Starinar 47 (1996) 105-125.

= P. C. RAMSL: Das eisenzeitliche Gräberfeld von Pottenbrunn. FÖ A11. Wien 2002.

= P. C. RAMSL: La nécropole laténienne de Pottenbrunn (Basse-Autriche), miroir des relations Est-

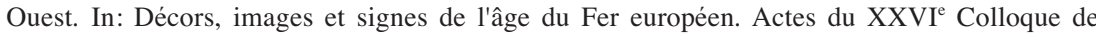
l'Association Française pour l'Etude de l'Age du Fer. Ed.: O. Buchsenschutz, A. A. Bulard, M.-B. Chardenoux, N. Ginoux. Supplément à la Revue archéologique du centre de la France. Tours 2003, 247-258.

= P. C. RAMSL: Das latènezeitliche Gräberfeld von Mannersdorf am Leithagebirge, Flur Reinthal Süd, Niederösterreich. MPK 74. Wien 2011.

= A. RAPIN: L'armement celtique en Europe: chronologie de son évolution technologique du $\mathrm{V}^{\mathrm{e}}$ au $\mathrm{I}^{\mathrm{er}}$ s. av. J.-C. Gladius 19 (1999) 33-67.

= P. Roualet: Les Jogasses. In: The Celts. Ed.: S. Moscati. Venice 1991, 121.

= A. RUSTOIU: Războinci şi societate Ĭn aria celtică Transilvăneană. Studii pe marginea mormintului cu coif de la Ciumeşti - Warriors and Society in Celtic Transylvania. Studies on the Grave with Helmet from Ciumeşti. Cluj-Napoca 2008.

= A. Rustoiu: The Celts and indigenous populations from the Southern Carpathian Basin. Intercommunity communication strategies. In: Iron Age Rites and Rituals in the Carpathian Basin. Proceedings of the International Colloquium from Târgu Mureş, 7-9 October 2011. Ed.: S. Berecki. Bibliotheca Mvsei Marisiensis 5. Târgu Mureș 2012, 357-390.

= A. RustoiU: Amphora-shaped glass and coral beads. Distant cultural connections in the Carpathian Basin at the beginning of the Late Iron Age. AKorr 45 (2015) 365-377. 
SANKOT 1998

SANKOT 2013

SCHIEL 2015

SCHNEIDER 2019

SCHWAB 1995

SCHWAPPACH 1971

SCHWAPPACH 1975

SCHWAPPACH 1979

SLADIĆ 2002

STÖLLNER 2002

SZABÓ 1974

SzABÓ 1992

SZABÓ 1994

SZABÓ 2005

SZABÓ 2007

SZABÓ 2009

SZABÓ 2015

SzABÓ et al. 2007

SZABÓ et al. 2012

SZABÓ et al. 2018

SZABÓ-PETRES 1992

SZABÓ-TANKÓ 2018

TANKÓ 2004

TANKÓ 2005

TANKÓ 2010

TANKÓ 2016

TANKÓ-EGRY 2009

TANKÓ et al. 2016
= P. SANKOT: «Münsinger Fibeln» aus den Gräberfeldern Böhmens. In: Münsingen Rain. Ein Markstein der keltischen Archäologie. Hrsg.: F. Müller. Schriften des Bernischen Historischen Museums 2. Bern 1998, 205-212.

= P. SANKOT: Burial in LT B-C1. In: VenCLOVÁ et al. 2013, 88-96.

$=$ H. SCHIEL: Das Latènegräberfeld von Neunkirchen (NÖ). Masterarbeit, Universität Wien. Wien 2015.

= Á. SCHNEIDER: Multivariate statistical analysis of archaeological contexts: the case study of the Late-Hallstatt-Early-Latène cemetery of Szentlörinc, Hungary. DissArch III/7 (2019) 101-150.

$=$ H. SchwAB: Deux nécropoles laténiennes à Gumefens (canton de Fribourg, Suisse). In: L'Europe celtique du $\mathrm{V}^{\mathrm{e}}$ au III ${ }^{\mathrm{e}}$ siècle avant J.-C. Actes du deuxième symposium international d'Hautvillers (8-10 octobre 1992). Éd.: J.-J. Charpy. Mémoires de la Société Archéologique Champenoise 9. Sceaux 1995, 239-258.

= F. Schwappach: Stempel des Waldalgesheimstils an einer Vase aus Sopron-Bécsidomb (West Ungran). HBA 1 (1971) 131-172.

= F. SCHWAPPACH: Zur Chronologie der östlichen Frühlatène-Keramik. Alba Regia 14 (1975) 109-136.

= F. SchWAPPACH: Zur Chronologie der östlichen Frühlatène-Keramik - On the Chronology of Eastern Early La Tène Pottery. Bad Bramstedt 1979

= M. SLADIĆ: Tragom ranih keltskih uticaja na prostoru Timočke Krajine (On tracing early Celtic influences in Timocka Krajina). Balcanica 32-33 (2002) 37-47.

$=$ TH. STÖLLnER: Hallstattzeit und der Beginn der Latènezeit im Inn-Salzach-Raum. Auswertung. Archäologie in Salzburg 3/I. Salzburg 2002.

= M. Szabó: Contribution à l'ètude de l'art et de la chronologie de La Tène ancienne en Hongrie. FolArch 25 (1974) 71-86.

= M. Szabó: Les Celtes de l'Est. Le Second Age du Fer dans la cuvette des Karpates. Paris 1992.

= M. SzABó: Kelta harcosok Delphoi elött és után. Adalékok az ókori kelták történetének egy kritikus periódusához (Guerriers celtes avant Delphoi et àpres. Contributions à une période critique de l'histoire des Celtes à l'antiquité). AT 38 (1994) 37-56.

= M. Szabó: A keleti kelták. A késő vaskor a Kárpát-medencében [The Eastern Celts. The Late Iron Age in the Carpathian Basin]. Budapest 2005.

= M. Szabó (dir.): L'habitat de l'époque de La Tène à Sajópetri Hosszú-dűlő. Budapest 2007.

= M. SzABó: Megjegyzések a Délkelet-Dunántúl késő vaskorához (Remarques sur le second âge du fer de la Transdanubie). ComArchHung 2009 (2009) 85-100.

= M. SzABÓ: A kelták Magyarországon [The Celts in Hungary]. In: M. Szabó-L. Borhy: Magyarország története az ókorban: Kelták és rómaiak. Bibliotheca archaeologica 4. Budapest 2015, 13-82.

= M. Szabó-K. TANKó-D. Szabó: Le mobilier céramique. In: Szabó 2007, 229-252.

= M. SzABÓ (dir.)-K. TANKÓ-Z. CZAJLIK (ass.): La nécropole celtique à Ludas - Varjú-dülö. Budapest 2012.

= M. SzABÓ (dir.)-Z. CZAJLIK-K. TANKÓ (ass.): La nécropole celtique à Sajópetri-Homoki-szőlőskert. Budapest 2018.

= M. SzABÓ-É. F. Petres: Decorated Weapons of the La Tène Iron Age in the Carpathian Basin. IPH 5. Budapest 1992

= M. SzABÓ-K. TANKó: La nécropole celtique à Sajópetri - Homoki-szőlőskert. In: SzABó et al. 2018, 9-224.

= K. TANKÓ: Rekonstruktion eines latènezeitlichen Grubenhauses aus Ménfőcsanak-Szeles (B. 83). ComArchHung 2004, 105-112.

= K. TANKó: A ménfőcsanaki késő vaskori település (The Late Iron Age settlement at Ménfőcsanak). PhD dissertation at ELTE University. [Manuscript.] Budapest 2005.

= K. TANKÓ: Late Iron Age settlement in the vicinity of Ménföcsanak (Road no. 83 and Bevásárlóközpont). In: Studia Celtica Classica et Romana Nicolae Szabó septuagesimo dedicata. Dir.: L. Borhy. Budapest 2010, 249-260.

$=\mathrm{K}$. TANKÓ: Chronological aspects of ceramic types from recently investigated La Tène settlements in Hungary. In: Iron Age Chronology in the Carpathian Basin : Proceedings of the International Colloquium from Târgu Mureş, 8-10 October 2015. Ed.: S. Berecki. Bibliotheca Mvsei Marisiensis 5. Cluj-Napoca 2016, 165-190.

= K. TANKÓ-I. EGRY: Kelta település Győr-Ménfőcsanak-Bevásárlóközpont területén. Az 1995. és 2006. évi ásatás (Celtic settlement excavations at Győr-Ménfőcsanak-Bevásárlóközpont between

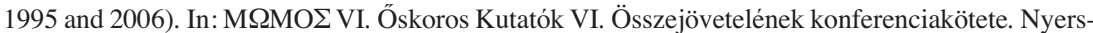
anyagok es kereskedelem, Köszeg, 2009. március 19-21. Ed.: G. Ilon. Szombathely 2009, 401-416.

= K. TANKó-Z. Tóth-L. RupniK-Z. Czajlik, S. Puszta: Short report on the archaeological research of the Late Iron Age cemetery at Gyöngyös. DissArch III/4 (2016) 307-324. 
TAPPERT 2007

= C. TAPPERT: Die eisenzeitliche Besiedlungsentwicklung im Stadtgebiet von Straubing (Niederbayern). In: Siedlungsdynamik und Gesellschaft. Beiträge des internationalen Kolloquiums zur keltischen Besiedlungsgeschichte im bayerischen Donauraum, Österreich und der Tschechischen Republik 2. - 4. März 2006 im Gäubodenmuseum Straubing. Hrsg.: J. Prammer, R. Sandner, C. Tappert. Jahresbericht des Historischen Vereins für Straubing und Umgebung, Sonderband 3. Straubing 2007, 173-206.

Tiefengraber-Wiltschke-Schrotta 2012 = G. Tiefengraber-K. Wiltschke-Schrotta: Der Dürrnberg bei Hallein. Abt. Gräberkunde. Die Gräbergruppe Moserfeld-Osthang. Dürrnberg-Forschungen 6. Rahden/Westfalen 2012.

Tiefengraber-Wiltschke-Schrotta 2014 = G. Tiefengraber-K. Wiltschke-Schrotta: Der Dürrnberg bei Hallein. Abt. Gräberkunde. Die Gräbergruppe Hexenwandfeld. Dürrnberg-Forschungen 7. Rahden/Westfalen 2014.

Tiefengraber-Wiltschke-Schrotta 2015a = G. Tiefengraber-K. Wiltschke-Schrotta: Der Dürrnberg bei Hallein. Abt. Gräberkunde. Die Gräbergruppen Lettenbühel und Friedhof. Dürrnberg-Forschungen 8. Rahden/Westfalen 2015.

Tiefengraber-Wittschke-Schrotta 2015b = G. Tiefengraber-K. Wiltschke-Schrotta: Der Dürrnberg bei Hallein. Abt. Gräberkunde. Die Gräbergruppe am Römersteig. Dürrnberg-Forschungen 9. Rahden/Westfalen 2015.

TODOROVIĆ 1974

= J. ToDOROvić: Skordisci. Istorija i kultura (Skordisci. History and Culture). Monumeanta archaeologica 2. Novi Sad-Beograd 1974.

TODOROVIĆ 1975

TREFNÝ 2016

$=$ J. ToDorović: Die Ethongenese der Skordisker. Alba Regia 14 (1975) 215-223.

$=$ M. TREFNÝ: Poznámky k některým halštatským sponám z Čech - Notes on some Hallstatt fibulae finds in Bohemia. In: Doba popelnicových polí a doba halštatská ve střední evropě. 2.: Materiál z XIII. mezinárodní konference „Popelnicová pole a doba halštatská.” Ed.: J. Juchelka. Opava-Brno 2016, 143-158.

TRUHELKa 1904

= C. TRuhelKa: Der vorgeschichtliche Pfahlbau im Savebette bei Donja Dolina. WMBH 9 (1904) $1-170$.

URBAN 1985

= O.-H. URBAN: Die latènezeitlichen Gräberfeld von Katzelsdorf und Guntramsdorf, Niederösterreich. ArchA 69 (1985) 13-55.

UzsOKI 1968

UZSOKI 1969a

= A. UzsoKI: Ménföcsanak ArchÉrt 95 (1968) 128.

= A. UzsoKI: Die Siedlungsgeschichte der La Tène B-C Periode des Komitats Győr-Sopron. MFMÉ (1969) 69-82.

UzSOKI 1969b

UzSOKI 1970a

= A. UzsoKI: Ménföcsanak. ArchÉrt 96 (1969) 253.

= A. UzsoKI: Előzetes jelentés a ménfőcsanaki kelta temető ásatásáról (Rapport préliminaire sur les fouilles de la nécropole celte de Ménföcsanak). Arrabona 12 (1970) 17-57.

UZSOKI 1970b

= A. Uzsoki: A ménföcsanaki kelta pajzs rekonstrukciós kísérlete (Опыт реконструкции кельтского щита из Менфёчанака - Essai de reconstitution du bouclier celtique de Ménfö́csanak). ArchÉrt 97 (1970) 97-108.

UZSOKI 1970c

UzsoKI 1987

= A. UzsoKi: Ménfőcsanak. ArchÉrt 97 (1970) 307.

= A. UzsoKI: Ménföcsanak. In: Corpus of Celtic Finds in Hungary I.: Transdanubia 1. Eds: T. Kovács, É. Petres, M. Szabó. Budapest 1987, 13-63.

VADÁSZ 1987

= É. VADÁsz: Komárom County II. In: Corpus of Celtic Finds in Hungary. I.: Transdanubia 1. Eds: T. Kovács, É. Petres, M. Szabó. Budapest 1987, 231-238.

VADAY 2003

= A. VADAY: A ménföcsanaki kelta lelőhely [The Celtic site at Ménföcsanak]. In: Magyarország régészete az ezredfordulón. Eds: Zs. Visy, M. Nagy. Budapest, 2003, 201-202.

VADAY 2004

= A. VADAY: The Celtic site at Ménföcsanak. In: Hungarian Archaeology at the Turn of the Millennium. Ed.-in-chief: Zs. Visy. Budapest, 2004, 201-202.

VADAY 2006a

$=\mathrm{A}$. VADAY: A ménföcsanaki kelta temető kronológiai modellje (The chronological model of the Celtic cemetery of Ménföcsanak-Chronologisches Modell des Kelten-Friedhofes von Ménföcsanak). Arrabona 44 (2006) 597-610.

VADAY 2006b

$=$ A. VADAY: The chronological model of the Celtic cemetery of Ménföcsanak. In: Thracians and Celts. Proceedings of the International Colloquium from Bistriţa 18-20 May 2006. Eds.: V. Sîrbu, D. L. Valida. Cluj-Napoca 2006, 279-294.

VÁLYI 1983

VenCLOVÁ 1990

VENCLOVÁ et al. 2013

= K. VÁLYI: Korai kelta leletek Balfról (Frühkeltische Funde in Balf). MFMÉ 1982-83 (1983) 95-113.

= N. Venclová: Prehistoric Glass in Bohemia. Praha 1990.

= N. Venclová (ed.)-P. Drda-J. Michálek-J. MilitkÝ-V. Salač-P. Sankot-V. Vokolek: The Prehistory of Bohemia. 6.: The Late Iron Age - The La Tène Period. Praha 2013.

VOIGT 1969

$=$ T. VoIGT. Zur Problematik der frühlatènezeitlichen Linsenflaschen. JMV 53 (1969) 415-436.

Open Access. This is an open-access article distributed under the terms of the Creative Commons Attribution 4.0 International License (https:// creativecommons.org/licenses/by/4.0), which permits unrestricted use, distribution, and reproduction in any medium, provided the original author and source are credited, a link to the CC License is provided, and changes - if any - are indicated. (SID_1)

Acta Archaeologica Academiae Scientiarum Hungaricae 71, 2020 